Universidade de São Paulo

Faculdade de Filosofia, Letras e Ciências Humanas

Departamento de Letras Modernas

Programa de Pós-Graduação em Estudos Linguísticos e Literários em Inglês

Elder Kôei Itikawa Tanaka

\title{
Inimigos públicos em Hollywood: estratégias de contenção e ruptura em dois filmes de gângster dos anos 1930-1940
}


Universidade de São Paulo

Faculdade de Filosofia, Letras e Ciências Humanas

Departamento de Letras Modernas

Programa de Pós-Graduação em Estudos Linguísticos e Literários em Inglês

\section{Inimigos públicos em Hollywood: estratégias de contenção e ruptura em dois filmes de gângster dos anos 1930-1940}

Elder Kôei Itikawa Tanaka

Tese apresentada ao Programa de Pós-Graduação em Estudos Linguísticos e Literários em Inglês do Departamento de Letras Modernas da Faculdade de Filosofia, Letras e Ciências Humanas da Universidade de São Paulo, para obtenção do título de Doutor em Letras.

Orientador: Prof. Marcos César de Paula Soares. 
Autorizo a reprodução e divulgação total ou parcial deste trabalho, por qualquer meio convencional ou eletrônico, para fins de estudo e pesquisa, desde que citada a fonte.

Catalogação na Publicação

Serviço de Biblioteca e Documentação

Faculdade de Filosofia, Letras e Ciências Humanas da Universidade de São Paulo

T161i

Tanaka, Elder Kôei Itikawa

Inimigos públicos em Hollywood: estratégias de contenção e ruptura em dois filmes de gângster dos anos 1930-1940 / Elder Kôei Itikawa Tanaka ; orientador Marcos César de Paula Soares. - São Paulo, 2015.

$183 \mathrm{f}$.

Tese (Doutorado)- Faculdade de Filosofia, Letras e Ciências Humanas da Universidade de São Paulo. Departamento de Letras Modernas. Área de concentração: Estudos Linguísticos e Literários em Inglês.

1. CINEMA. 2. GANGSTERES. 3. CRÍTICA

CINEMATOGRÁFICA. 4. HISTÓRIA DO CINEMA. 5. CENSURA.

I. Soares, Marcos César de Paula, orient. II. Título. 


\section{Folha de aprovação}

Nome: Tanaka, Elder Kôei Itikawa

Título: Inimigos públicos em Hollywood: estratégias de contenção e ruptura em dois filmes de gângster dos anos 1930-1940

Tese apresentada à Faculdade de Filosofia, Letras e Ciências Humanas da Universidade de São Paulo para obtenção do título de Doutor em Letras.

Aprovado em:

\section{Banca Examinadora:}

Prof. Dr.

Julgamento:

Prof. Dr.

Julgamento:

Prof. Dr.

Julgamento:

Prof. Dr.

Julgamento:
Instituição:

Assinatura:

Instituição:

Assinatura:

Instituição:

Assinatura:

Instituição:

Assinatura: 


\section{Agradecimentos}

À Coordenação de Aperfeiçoamento de Pessoal de Nível Superior (CAPES), pelo financiamento de nossa pesquisa no Brasil e no exterior.

À Comissão Fulbright Brasil, pela oportunidade de realizar parte da pesquisa nos EUA, e aos amigos Matt Smith e Frances Novack, da Fulbright Association of Greater Philadelphia, por ter nos recebido com tanto carinho.

Ao orientador da pesquisa, Marcos César de Paula Soares, pela orientação exigente e por ter confiado no meu trabalho desde o mestrado.

Ao professor Peter Decherney, pela orientação em solo norte-americano.

Aos professores da banca de qualificação, Antonio Aleixo e Marcos Fabris, pela leitura atenta do relatório e por todos os conselhos e recomendações para o prosseguimento da pesquisa.

A todos os funcionários da Faculdade de Filosofia, Letras e Ciências Humanas (FFLCH), em especial à Edite, ao Junior, e aos colegas do Departamento de Letras Modernas (DLM), pela eficiência na resolução dos problemas e no esclarecimento de dúvidas.

À Solange Grossi e Fabiana Tavares, pela oportunidade de discutir questões relacionadas ao meu trabalho, e pela amizade desde os tempos de graduação.

Aos amigos do Mocassim - Elton Furlanetto, Cristiane Maria, Neyde Branco, Roberta Fabbri, Maíra Malosso e Fabiana Vilaço - pelas discussões animadas e leitura atenta de trechos dessa tese.

Aos meus pais e à minha família, pelo apoio incondicional.

À Paola, por tudo, sempre. 


\section{Resumo}

TANAKA, Elder Kôei Itikawa. Inimigos públicos em Hollywood: estratégias de contenção e ruptura em dois filmes de gângster dos anos 1930-1940. 183p. Tese (Doutorado) Faculdade de Filosofia, Letras e Ciências Humanas, Universidade de São Paulo, 2015.

O objetivo dessa tese é investigar de que maneira Little Caesar (Mervyn Leroy, 1931) e Force of Evil (Abraham Polonsky, 1947) registram, dentro do gênero gângster, questões como a Depressão na década de 1930, e o macarthismo na década de 1940, ao mesmo tempo em que estabelecem homologias estruturais entre o crime organizado e o mundo dos negócios. Tais questões surgem nesses dois filmes por força da matéria histórica envolvida nas condições de produção. Nossa tese é de que os filmes configuram, em diferentes medidas, estratégias de representação da matéria histórica apesar das tentativas de seu apagamento, como a censura e o macarthismo.

Palavras-chave: cinema norte-americano; filmes de gângster; anos 1930; anos 1940; censura; macarthismo. 


\begin{abstract}
TANAKA, Elder Kôei Itikawa. Public enemies in Hollywood: strategies of containment and rupture in two gangster films from the 1930s-1940s. 183p. Thesis (Doctorate) - Faculdade de Filosofia, Letras e Ciências Humanas, Universidade de São Paulo, 2015.

The aim of this thesis is to analyze how Little Caesar (Mervyn Leroy, 1931) and Force of Evil (Abraham Polonsky, 1947) portray, in the gangster genre, historically relevant questions such as the Great Depression in the 1930s and McCarthyism in the 1940s, while establishing structural homologies between organized crime and the business world. These themes arise in both films due to the strength of the historical substance implicated in the conditions of production. Our thesis is that these films depict, in different proportions, strategies of representation of the historical substance in spite of attempts to suppress it, such as censorship and McCarthyism.
\end{abstract}

Keywords: American cinema; gangster films; 1930s; 1940s; censorship; McCarthyism. 


\section{Sumário}

$\begin{array}{ll}\text { Introdução } & 9\end{array}$

Capítulo 1: Little Caesar 16

$\begin{array}{lr}\text { A religião como vetor regressivo } & 18\end{array}$

Hollywood pre-Code e o subtexto homossexual 25

A crise de 1929 e a concorrência pelo emprego 41

$\begin{array}{ll}\text { A administração do tempo } & 47\end{array}$

O American Dream e a indústria cultural

A tragédia da classe trabalhadora 66

$\begin{array}{ll}\text { Aparência e essência } & 70\end{array}$

$\begin{array}{ll}\text { O mito da Máfia } & 80\end{array}$

Capítulo 2: Force of Evil 88

$\begin{array}{ll}\text { Equivalência entre negócios e crime } & 97\end{array}$

$\begin{array}{ll}\text { Tucker Enterprises Inc. } & 105\end{array}$

Caim, Abel, e os negócios da família Morse 112

$\begin{array}{lr}\text { Doris e a mercadoria } & 128\end{array}$

$\begin{array}{ll}\text { A censura no pós-guerra e o uso do som } & 137\end{array}$

$\begin{array}{ll}\text { Lealdade em tempos sombrios } & 146\end{array}$

$\begin{array}{ll}\text { O fechamento das possibilidades } & 154\end{array}$

A arquitetura de Nova Iorque e o "mundo real" 164

$\begin{array}{ll}\text { A morte de Leo } & 166\end{array}$

$\begin{array}{ll}\text { Considerações finais } & 172\end{array}$

$\begin{array}{ll}\text { Referências bibliográficas } & 178\end{array}$ 


\section{Introdução}

Uma das características centrais da ideologia dominante no Reino Unido e nos Estados Unidos durante a segunda metade do século XIX e os primeiros anos do século XX foi a ausência, ou ao menos extrema debilidade, de conceitos de luta de classe como instrumentos de interpretação de fenômenos sociais. (...) Isso se refletiu na estabilidade da sociedade burguesa e na autoconfiança da classe dominante. (...) Nessas circunstâncias, era natural para elas assimilar a revolta com a ordem social como atividade criminal, e identificar o proletariado rebelde como "classe criminosa".

Ernest Mandel ${ }^{1}$

O termo gângster denomina, em linhas gerais, um determinado criminoso urbano que trabalha em grupos organizados hierarquicamente, e foi utilizado pela primeira vez nos noticiários policiais do início do século XX. Graças à disseminação de sua figura por meio da indústria cultural, o gângster se tornou um ícone da cultura popular dos EUA como uma mescla de fatos e ficção no imaginário do cidadão norte-americano.

Uma das causas do fortalecimento do gangsterismo nos Estados Unidos foi a promulgação da Lei Seca, que proibiu a produção e venda de bebidas alcoólicas de 1920 a 1933 no país. Embora gangues ocupassem os centros urbanos há tempos, a proibição do comércio de bebidas alcoólicas, somada à crise de 1929, proporcionou oportunidades para que novos líderes criminosos surgissem e prosperassem. Gângsteres como Al Capone, Jim Colosimo e Frank Costello ganharam notoriedade quando surgiram como figuras do crime organizado ao longo da primeira metade do século XX nos EUA.

Pode-se dizer que o gangsterismo era resultado do ambiente socioeconômico turbulento do início do século XX - enquanto os anos 1920 promoviam o consumismo e a distância entre ricos e pobres aumentava, os gângsteres, originários das classes mais pobres, desafiavam os limites entre as classes sociais ao desfilarem pelas metrópoles em roupas caras

\footnotetext{
${ }^{1}$ Mandel, E. Delightful Murder - A social history of the crime story. Minneapolis: Univeristy of Minnesota Press, 1984, p. 44. Todas as obras citadas neste trabalho que não possuem tradução oficial para o português têm tradução nossa.
} 
e carros luxuosos. ${ }^{2}$ Alguns críticos especializados em filmes de gângster, como Jack Shadoian, consideram que esse tipo de personagem expõe duas ideologias norte-americanas fundamentais e opostas:

Há uma contradição inerente no pensamento norte-americano entre a América como uma terra de oportunidades, e a visão de uma sociedade democrática e sem divisão de classes sociais. Ambas as crenças são profundamente arraigadas, e a contradição não pode ser resolvida. É bom seguir em frente, mas é errado seguir em frente. É bom ser um indivíduo, mas assim você se separa dos outros. O gângster é um veículo de exposição desse problema central da sociedade norteamericana. ${ }^{3}$

Parte da popularização da figura do gângster se deu graças ao cinema. Durante o período do cinema mudo, o gângster ocupava as telas em "melodramas do submundo", nos quais o mundo dos "outros" se configurava como o lado negro e oposto ao mundo "oficial" da sociedade. Entre essas produções encontra-se The Musketeers of Pig Alley, de D. W. Griffith (1912), considerado o primeiro filme de gângster da história do cinema. Seu enredo é baseado em manchetes de jornais da época sobre um tiroteio nas ruas de Nova Iorque. Segundo o crítico Jonathan Munby, Griffith utilizou cenários e atores locais para registrar sua visão sobre o "outro lado" da cidade. ${ }^{4}$

Entretanto, foi com o advento do cinema falado em 1927 que o gênero alcançou maior destaque. Little Caesar (Mervyn LeRoy, 1931), lançado no Brasil como “Alma no Lodo”, é considerado o primeiro grande filme de gângster desse período e contribuiu para a popularização da figura desse tipo de criminoso, associando-o no imaginário coletivo a grupos de imigrantes judeus, irlandeses, africanos, asiáticos e, principalmente, italianos. ${ }^{5} \mathrm{Tal}$ associação ocorreu pela ascendência tanto dos personagens como dos atores, cujos modos de fala característicos ganharam evidência com a sincronização de som e imagem na tela do cinema.

Apesar do sucesso nas bilheterias do "primeiro ciclo" de filmes desse gênero - Little Caesar, The Public Enemy (Wiliam A. Wellman, 1931) e Scarface (Howard Hawks, 1932),

\footnotetext{
${ }^{2}$ Cf. Gardaphe, F. L. Mafia stories and the American gangster. In: Nickerson, Catherine R. The Cambridge Companion to American Crime Fiction. Cambridge: Cambridge University Press, 2010, p. 110.

${ }^{3}$ Shadoian, J. Dreams and Dead Ends: The american gangster film. New York: Oxford University Press, 2003, p. 6

${ }^{4}$ Cf. Munby, J. Public Enemies, Public Heroes - Screening the Gangster from Little Caesar to Touch of Evil. Chicago: The University of Chicago Press, 1999, p. 24.

${ }^{5}$ Cf. Gardaphe, F. L., op. cit., p. 111.
} 
entre outros -, tais produções estavam longe de ser uma unanimidade. Entre a crítica especializada de esquerda da época, por exemplo, o filme de gângster, assim como o filme de terror, não era levado a sério, pois ambos eram considerados, de acordo com o historiador Richard Pells, meras formas de escapismo frívolo em um período em que era necessária uma abordagem mais progressista. Entretanto, segundo Pells, quando algum filme se propunha a seguir tais demandas, o resultado normalmente era a diluição do senso crítico. Uma exceção que merece ser mencionada é I am a Fugitive from a Chain Gang, de 1932, dirigido por Mervyn LeRoy, mesmo diretor de Little Caesar. O filme denuncia a brutalidade do sistema prisional e questiona a aplicação das leis ao denunciar a sociedade norte-americana da época em vez do criminoso. ${ }^{6}$ Já sob a perspectiva dos movimentos conservadores ligados à igreja católica, os filmes de gângster eram uma afronta à moral e aos bons costumes por "glorificar" o bandido e exaltar na tela sua trajetória criminosa, ainda que o protagonista sempre recebesse como punição sua morte ao final da narrativa.

Para atender à pressão desses movimentos, foi redigido, no início da década de 1930, o Production Code (Código de Produção), documento com uma série de regras para a produção cinematográfica que formalizou a autocensura de Hollywood e provocou transformações progressivamente conservadoras nas narrativas produzidas pelos estúdios norte-americanos. No caso do filme de gângster, os roteiristas foram obrigados a diminuir a quantidade de cenas violentas - principalmente os assassinatos e tiroteios - e a evitar que o espectador sentisse qualquer "simpatia pelo crime, pelo mal ou pelo pecado" ". Em alguns casos, como em Manhattan Melodrama (W. S. Van Dyke, 1934), a estratégia adotada foi cindir o protagonismo da narrativa entre um gângster (Clark Gable) e um advogado (William Powell); em outros casos, o antagonista do gângster era representado por uma figura religiosa, como em Angels With Dirty Faces (Michael Curtiz, 1938). Outro recurso utilizado foi escalar protagonistas do primeiro ciclo para os papéis de homens da lei, como o detetive interpretado por Edward G. Robinson em Bullets or Ballots (William Keighley, 1936), ou James Cagney no papel de agente do FBI em G-Men (William Keighley, 1935).

Na transição para a década de 1940, High Sierra (Raoul Walsh, 1941) é considerado o último grande filme de gângster antes de Pearl Harbor. No período pós-guerra, o gângster voltou a Hollywood influenciado esteticamente pelo cinema noir, com protagonistas

\footnotetext{
${ }^{6}$ Cf. Pells, R. H. Radical Visions and American dreams: culture and social thought in the Depression years. New York: Harper\&Row, 1973, p. 274-275.

${ }^{7}$ Cf. Maltby, R. Censorship and Self-Regulation. In: Nowell-Smith, G. (ed.). The Oxford History of World Cinema. New York: Oxford University Press, 1996, p. 241-242.
} 
envolvidos em conflitos internos, e em rota de colisão não só com a polícia, mas também com a sua própria gangue ou seu chefe. Body and Soul (Robert Rossen, 1947), Force of Evil (Abraham Polonsky, 1948) e White Heat (Raoul Walsh, 1949) são exemplos de filmes do período.

O fim da década de 1940 e o início da década de 1950 marcaram o início da "paranoia sobre organizações secretas (tanto Comunistas como criminosas)"8 da Guerra Fria. No Congresso norte-americano, tal paranoia se traduziu na formação de dois comitês: o Special Committee to Investigate Crime in Interstate Commerce (conhecido por Kefauver Committee) e o House Committee on Un-American Activities (HUAC). O primeiro realizou interrogatórios públicos em diversos estados norte-americanos entre 1950 e 1952, nos quais cerca de seiscentas testemunhas ligadas ao crime organizado no país prestaram depoimentos. Frank Costello - à época, considerado o chefe por trás das principais operações desse tipo de crime nos EUA - foi um dos interrogados ${ }^{9}$. De acordo com os sociólogos Calvin J. Larson e Gerald R. Garrett, na visão desse comitê,

a Máfia estava mais do que estabelecida na América e era parte de uma conspiração criminosa global cujo objetivo era a dominação social. A ameaça da Máfia era comparada ao espectro do comunismo mundial. O presidente do Comitê Anticrime de Nova Iorque expressou o medo de muitos quando observou que 'Joe Stalin, se tivesse planejado dessa maneira, não teria achado meio mais rápido e seguro de derrotar as democracias do que subsidiar esses gângsteres. Eu me pergunto se os soviéticos não estão, ao menos em alguma medida, incitando esses vermes a corromper nosso sistema de lei e ordem'. ${ }^{10}$

As investigações do Kefauver Committee não tiveram o impacto esperado porque o comitê pretendia revelar uma "conspiração sinistra e secreta", mas só conseguiu encontrar uma mal disfarçada, embora bem organizada, operação comercial. ${ }^{11}$ Já o HUAC, que investigava a participação de comunistas na indústria cinematográfica, teve resultados mais efetivos, pois conseguiu criar uma "lista negra" (blacklist) incluindo atores, diretores, roteiristas e produtores suspeitos de participação no Partido Comunista ou em atividades "subversivas". Os artistas inclusos nessa lista não puderam mais trabalhar em Hollywood por quase duas

\footnotetext{
${ }^{8}$ Mason, F. American Gangster Cinema - from Little Caesar to Pulp Fiction. New York: Palgrave Macmillian, 2002, p. xvii.

${ }^{9}$ Cf. Larson, C. J., Garrett, G. R. Crime, Justice and Society - Second Edition. Walnut Creek: AltaMira Press, 1996, p. 152-153.

${ }^{10}$ Ibidem, p. 152.

${ }^{11}$ Ibidem, p. 153.
} 
décadas, e os filmes de gângster refletiram na tela o clima de paranoia coletiva desse período histórico ao colocar em evidência a gangue em vez do gângster em narrativas que registravam ou uma sociedade dominada por sistemas restritivos - The Asphalt Jungle (John Huston, 1950) e On the Waterfront (Elia Kazan, 1954) -, ou indivíduos fragmentados, apartados das estruturas sociais - The Enforcer (Bretaigne Windust, Raoul Walsh, 1951). ${ }^{12}$

Na década de 1960, os filmes de gângster caracterizaram-se, segundo o crítico Fran Mason, por configurarem tentativas de "representação hiper-realista" dos criminosos das décadas anteriores. Diversos filmes biográficos (bio-pics) como Al Capone (1959), The Rise and Fall of Legs Diamond (1960), The Valentine's Day Massacre (Roger Corman, 1967), Bonnie and Clyde (Artur Penn, 1967) e Dillinger (John Millus, 1973) surgiram nesse período. Tais filmes, segundo Mason, tinham como foco o "espetáculo da ação e da violência" que seguia a "lógica do excesso", produzida com o intuito de entreter o público jovem que frequentava os drive-ins norte-americanos. ${ }^{13}$

De acordo com Shadoian, os dois primeiros episódios da trilogia The Godfather lançados respectivamente em 1972 e 1975 com direção de Francis Ford Coppola -, restituíram ao gênero gângster na década de 1970 a visibilidade que ele possuía nos anos 1930 e no período pós-guerra. ${ }^{14}$ A complexidade da narrativa e a iconografia da Máfia, igualmente "exótica e familiar" 15 , não só fizeram dessa trilogia sucesso de público e crítica, como também geraram novos paradigmas para o gênero gângster nas décadas seguintes. Scarface (Brian de Palma, 1983), Once upon a time in America (Sergio Leone, 1984), The Untouchables (Brian de Palma, 1987), Goodfellas (Martin Scorsese, 1990), Reservoir Dogs (Quentin Tarantino, 1991), Casino (Martin Scorsese, 1995), Donnie Brasco (Mike Newell, 1997), Gangs of New York (Martin Scorsese, 2002), American Gangster (Ridley Scott, 2007) e Lawless (John Hillcoat, 2012) são apenas alguns dos exemplos de filmes que gozaram da popularidade do gângster em Hollywood a partir de The Godfather.

Embora o filme de gângster desfrute de grande simpatia do público brasileiro, há pouquíssimos trabalhos acadêmicos em português com análises das narrativas e do material

\footnotetext{
${ }^{12}$ Cf. Mason, F. American Gangster Cinema - from Little Caesar to Pulp Fiction. New York: Palgrave Macmillian, 2002, p. xvii.

13 Ibidem, p. 123.

${ }^{14}$ Cf. Shadoian, J. Dreams and Dead Ends: The american gangster film. New York: Oxford University Press, 2003, p. 268.

${ }^{15}$ Cf. Mason, F., op. cit., p. 130.
} 
histórico relacionado ao assunto. ${ }^{16} \mathrm{O}$ presente trabalho tem o objetivo de preencher parte dessa lacuna ao discutir, de maneira aprofundada, dois dos filmes citados anteriormente: Little Caesar e Force of Evil. Sob a perspectiva do materialismo histórico, nosso interesse nesses filmes se baseia no fato de que ambos registram diferentes momentos de turbulência na política e na economia norte-americanas, além de pertencerem a períodos distintos tanto da censura em Hollywood, como dos movimentos sindicais nos EUA.

Diante de suas respectivas matérias históricas, Little Caesar e Force of Evil nos oferecem a oportunidade de observar diferentes etapas no processo de representação dos trabalhadores dentro da indústria cinematográfica norte-americana. Nesse âmbito, o filme de gângster cumpre uma função dialética, pois permite que o trabalhador se veja em cena - por meio de atores com quem compartilha ascendências e modos de fala - ao mesmo tempo em que acompanha uma narrativa que criminaliza sua própria classe social. Dentro dessa perspectiva, o filme de gângster produzido nesse período configura uma tentativa de construir uma representação cultural da classe trabalhadora organizada qualificando-a como "gangue", no sentido de "associação de malfeitores".

Todavia, a análise mais detida dessas narrativas nos mostra que elas não se resumem à criminalização do trabalhador. Além de abordarem temas como a crise econômica nos anos 1930 e a perseguição política nos anos 1940, ambos os filmes estabelecem homologias estruturais entre o crime organizado e o mundo dos negócios. Tais questões surgem nessas narrativas por força da matéria histórica envolvida nas condições de produção. Dessa forma, nossa tese é de que Little Caesar e Force of Evil configuram, em diferentes medidas, estratégias de representação da matéria histórica apesar das tentativas de seu apagamento, como a censura e o macarthismo.

A fim de explorar essas questões, organizamos nosso trabalho em três partes: $\mathrm{O}$ Capítulo 1 - Little Caesar é dedicado ao filme de Mervyn Leroy. Considerado o precursor dos filmes sonoros de gângster do chamado período "clássico" desse gênero, Little Caesar inaugura um ciclo de filmes em que a classe trabalhadora nos Estados Unidos é sujeito em Hollywood, ao mesmo tempo em que é associada ao crime organizado. Em vez de se

\footnotetext{
${ }^{16}$ Nossa pesquisa identificou apenas dois trabalhos de pós-graduação, além de artigos dos mesmos autores publicados em revistas científicas e comunicações apresentadas em congressos: Benoski, D. A. Violência e mobilidade social nos filmes de gângster. Florianópolis, 2009. Tese de doutorado. Centro de Filosofia e Ciências Humanas, Universidade Federal de Santa Catarina; Silva, A. C. A Representação Social do Gângster em "Scarface" e em "O Poderoso Chefão": Uma Análise da Linguagem e da Estrutura Cinematográfica. Marília, 2008. Dissertação de mestrado. Faculdade de Comunicação. Universidade de Marília.
} 
organizar como classe e buscar uma saída mais produtiva coletivamente, os proletários em Little Caesar optam por enfrentar a Depressão através do crime, e passam a utilizar métodos burgueses para chegar ao poder. Nesse contexto, o filme apresenta simultaneamente diversos materiais - como o crime organizado, o American Dream, a religião, e até mesmo um subtexto homossexual - que dão à narrativa um enorme potencial crítico. Nosso objetivo com esse capítulo é, por meio da análise de algumas das cenas de Little Caesar, demonstrar de que maneira esses temas são aproveitados no filme.

Em seguida, discutimos, no Capítulo II - Force of Evil, de que maneira as condições de produção interferiram na execução e no produto final da obra. Resultado do esforço conjunto de artistas progressistas, como o diretor Abraham Polonsky e o ator John Garfield, Force of Evil combina, tanto em sua forma como em seu conteúdo, a constante ameaça de perseguição política com uma liberdade criativa poucas vezes vista em Hollywood. Além disso, embora seja considerado um filme de gângster, o filme de Polonsky se destaca de produções anteriores por refuncionalizar os elementos que a narrativa tradicional de gângster oferecia, como a ascensão e queda do criminoso, ou o American Dream. Veremos de que forma se dá essa refuncionalização e quais os efeitos desse processo para a narrativa.

Em nossas Considerações finais, buscamos analisar as estratégias adotadas por ambas as produções a fim de comparar os limites e conquistas dos projetos de Mervyn LeRoy e Abraham Polonsky com obras de outros artistas de esquerda no cinema, como Bertolt Brecht e Herbert J. Biberman. 


\section{Capítulo 1 - Little Caesar}

Sou apenas um homem de negócios... (...) Esse nosso sistema americano - chame de capitalismo, ou do que quiser -, dá a cada um de nós uma grande oportunidade, se a agarrarmos com as duas mãos e soubermos aproveitá-la ao máximo... Fiz dinheiro atendendo a uma demanda popular... Quando eu vendo bebida, é contrabando. Quando meus clientes a servem em bandejas de prata no Lake Shore Drive, é hospitalidade... Porque deveriam me chamar de inimigo público?

Al Capone ${ }^{17}$

Baseado no romance homônimo de William Burnett publicado em 1929, Little Caesar tem a direção de Mervyn LeRoy ${ }^{18}$. O filme narra o percurso do protagonista Caesar Enrico Bandello, ou somente "Rico" (interpretado por Edward G. Robinson), desde sua ascensão à liderança da gangue durante a Lei Seca até sua queda. Joe Massara (interpretado por Douglas Fairbanks Jr.) é o parceiro de Rico no início do filme, mas entra em conflito com o protagonista ao longo da narrativa, pois quer sair da vida de crimes. A obra estreou nos cinemas norte-americanos em 1931 pelos estúdios da Warner Brothers, que viu em seu êxito uma oportunidade para produzir uma série de outros longas metragens cujos protagonistas também são gângsteres. O crítico Andrew Bergman afirma que

o sucesso de Little Caesar nas bilheterias não poderia senão preocupar líderes cívicos, mas a combinação de ultraje moral [do gângster] e sucesso financeiro teve um efeito curioso nos produtores dos filmes. Sabendo pelos resultados nas bilheterias que o filme de gângster era um bom negócio, eles intensificaram a produção de sucessores de Caesar; cientes de suas responsabilidades com a sociedade, eles tentaram racionalizar o conteúdo dos filmes. ${ }^{19}$

\footnotetext{
${ }^{17}$ Capone, A. apud Maltby, R. The spectacle of criminality. In: Slocum, D. J. (ed.) Violence and American Cinema. New York: Routledge, 2001, p. 127.

${ }^{18}$ Mervyn LeRoy foi indicado ao Oscar de 1940 como produtor do filme "O mágico de Oz" e trabalhou como diretor em Hollywood até a década de 1960. (Cf. Mervyn LeRoy - IMDB. Disponível em http://www.imdb. com/name/nm0503777/ - acessado em 10/01/2014).

${ }^{19}$ Bergman, A. We're in the Money: Depression America and its films. Chicago: Ivan R. Dee, 1992, p. 67.
} 
Antes mesmo da aparição dos créditos iniciais, o espectador de Little Caesar vê na tela a capa do romance de W. R. Burnett, que serviu como base para o enredo do filme. Segundo o crítico Richard Jewel, a Warner Brothers fez questão de enfatizar que o roteiro do filme foi baseado num livro de sucesso, considerado um dos primeiros romances sobre gângsteres. ${ }^{20} \mathrm{~A}$ adaptação para o cinema, no entanto, modificou a narrativa criada por Burnett em pontos decisivos - do comportamento de alguns personagens ao destino de vários deles no fim do filme.

Um episódio descrito por Paul Buhle e Dave Wagner em Radical Hollywood exemplifica bem que tipo de relação Hollywood estabelecia com os autores dos romances que utilizava como fonte para seus filmes. Na cerimônia de estreia de Little Caesar em Los Angeles, os executivos da Warner Bros. orgulhosamente apresentaram os atores, diretor, diretor de fotografia e, por último, W. R. Burnett, como "fonte literária" para o filme, ao que o mestre de cerimônias na ocasião prontamente assinalou de maneira jocosa que "sempre é preciso haver um escritor". Burnett, indignado com o tratamento a ele dispensado, discretamente mandou o mestre de cerimônias "se danar". Para Buhle e Wagner, Burnett teve o privilégio de ter sido apresentado ao público na estreia do filme mesmo não tendo participado da elaboração do roteiro, cujo trabalho ficou sob responsabilidade de Francis Faragoh, um imigrante judeu húngaro que sequer foi mencionado na supracitada cerimônia. $^{21}$

A presença de Faragoh como roteirista de Little Caesar é um dado relevante para nossa análise porque se trata de uma figura importante na indústria cultural norte-americana. Antes de seguir para Hollywood, Faragoh fez parte, durante a década de 1920, do New Playwrights' Theatre, um grupo de teatro nova-iorquino de esquerda cujos integrantes incluíam John Dos Passos (autor de U.S.A.) e Michael Gold (fundador do jornal New Masses e autor de Jews Without Money). ${ }^{22}$ Faragoh foi um dos pioneiros no sindicato dos roteiristas de Hollywood (Screen Writers Guild) e trabalhou em diversos filmes ao longo da década de 1930, mas sua carreira foi abreviada pela sua inclusão na "lista negra" durante o macarthismo. Segundo Buhle e Wagner, Faragoh recebeu um roteiro de Little Caesar que havia sido reprovado e reconstruiu-o como o conhecemos hoje. ${ }^{23}$ Dessa maneira, Faragoh é

\footnotetext{
${ }^{20}$ Cf. Commentary by Richard Jewell. In: Little Caesar. Direção: Mervyn LeRoy. Burbank: Warner Home Video, 2005. 1 DVD (78 min), NTSC, P\&B.

${ }^{21}$ Cf. Buhle, P., Wagner, D. Radical Hollywood. New York: The New Press, 2002, p. 1.

${ }^{22}$ Cf. Carr, V. S. Dos Passos: a life. Evanston: Northwestern University Press, 2004, p. 216

${ }^{23}$ Cf. Buhle, P.; Wagner, D. op. cit., p. 13-14.
} 
responsável pelas adaptações feitas do romance para o cinema que serão apontadas ao longo de nossa análise.

\section{A religião como vetor regressivo}

Logo após os créditos do filme, surge na tela a seguinte epígrafe: “... Pois todos os que empunham a espada, pela espada morrerão. - Mateus 26-52" (Figura 1). Na passagem, o apóstolo narra a reação de Jesus Cristo no momento em que um de seus seguidores ataca o homem que levava Jesus preso após a traição de Judas. A forma de apresentação do texto - impresso em tipografia gótica sobre um papel envelhecido - funciona como uma moldura que dá um ponto de vista cristão à narrativa.

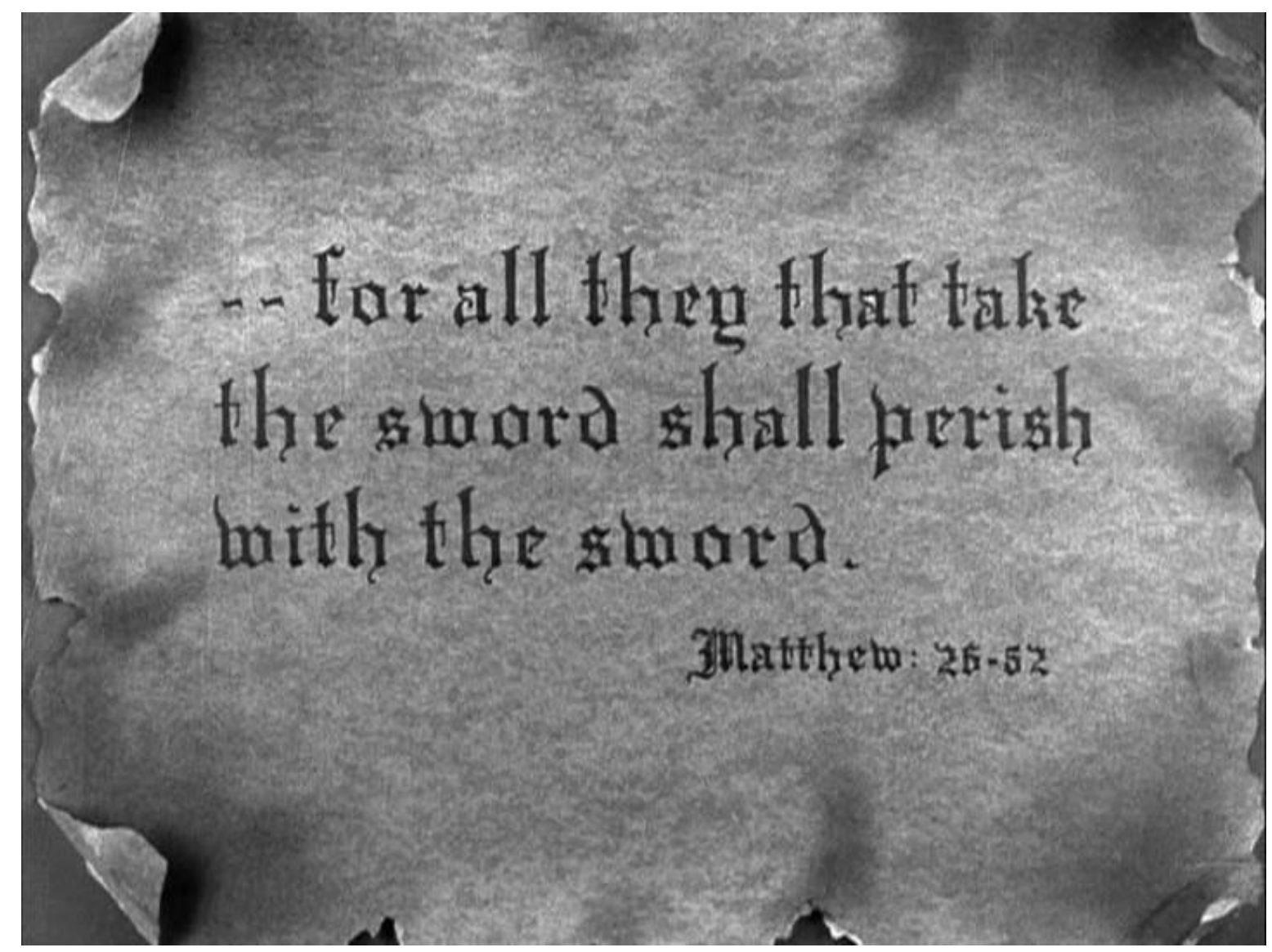

Figura 1 - A epígrafe do filme. 
A passagem bíblica, no entanto, é ambígua. Levando-se em conta a narrativa de Little Caesar como um todo, levantamos diferentes interpretações para essa citação no contexto das condições de produção do filme: uma delas iria contra o uso da violência, visando ao apaziguamento - e, por que não, ao controle - dos ânimos dos espectadores de Little Caesar, que começavam a viver os efeitos da Depressão no início da década de 1930 e poderiam enxergar no protagonista um modelo a ser seguido. Uma segunda interpretação iria ao encontro de uma justiça cristã, que condenaria o criminoso/pecador a um castigo divino proporcional aos seus delitos. O fim trágico de Rico corrobora essa última hipótese.

Vale notar que no romance Little Caesar, a epígrafe é de Maquiavel: “A primeira lei de qualquer ser é a autopreservação. Você semeia cicuta e espera ver espigas de milho amadurecerem"24. Segundo o próprio W. R. Burnett,

ninguém entendeu o que eu quis dizer com a citação de Maquiavel na epígrafe de Little Caesar. (...) Quer dizer que, se você tem esse tipo de sociedade, ela irá produzir homens assim [como Rico]. Era isso que eu procurava, um tipo. Rico estava condenado desde o princípio. $^{25}$

Richard Jewell justifica a mudança das epígrafes devido ao provável desconhecimento que os espectadores tinham em relação a Maquiavel. Podemos considerar que o texto bíblico fosse mais próximo do espectador de Little Caesar do que os escritos do cientista político italiano. Entretanto, a tentativa de simplificar a recepção da mensagem provocou mais ambiguidades, o que pode ser produtivo sob o ponto de vista crítico.

Por um lado, é possível enxergar na inclusão da passagem bíblica no início de Little Caesar um viés ideológico: o tom crítico à sociedade norte-americana desejado por Burnett na escolha da epígrafe de seu romance pode se diluir no moralismo cristão conservador oferecido aos espectadores do filme no cinema. O controle do ímpeto da classe trabalhadora e a manutenção do status quo poderiam ser mais interessantes aos detentores dos meios de produção em Hollywood do que o desenvolvimento de um espírito crítico na plateia de Little Caesar.

\footnotetext{
24 "The first law of every being is to preserve itself and live. You sow hemlock, and expect to see ears of corn ripen". Burnett, W. R. Little Caesar. New York: The Dial Press, 1958, p. 13. Todas as citações do romance de W. R. Burnett têm tradução nossa.

${ }^{25}$ McGilligan, P. \& Mate, K. W. R. Burnett: The Outsider. In: Backstory: interviews with screenwriters of Hollywood's golden age. Berkeley and Los Angeles: University of California Press, 1986, p. 57.
} 
Por outro lado, a ambiguidade da epígrafe nos permite levantar uma terceira interpretação: a da reciprocidade da violência, nos termos da lei de Talião (olho por olho, dente por dente). As condições de produção do filme nos levam a crer que essa interpretação justificaria tanto a ação violenta do Estado contra o gangsterismo, como a reação proporcional da classe trabalhadora - que frequentava regularmente as salas de cinema na época - às agressões sofridas no período pós-1929, como o aumento da desigualdade social, o preconceito contra os imigrantes e as altas taxas de desemprego durante a Depressão. De acordo com esse ponto de vista, Rico configuraria, dentro da indústria cultural, o potencial transgressor da classe trabalhadora: por meio do protagonista de Little Caesar, os espectadores veriam na tela do cinema como se daria o conflito armado no acerto de contas dos trabalhadores pelos abusos sofridos naquele período histórico.

Além da epígrafe retirada da Bíblia, a presença da religião é reiterada tanto no filme como no romance por meio do personagem Tony Passalacqua (William Collier Jr.), um dos integrantes da gangue de Rico. Em determinado momento de Little Caesar, Tony se acovarda depois de ter participado de um latrocínio com a gangue; durante a fuga, ele bate o carro e corre para sua casa. Ocorre, então, um diálogo entre Tony e sua mãe. O rapaz está transtornado e anda de um lado para o outro da sala. Sua mãe está preocupada com ele, que não dorme há dias e nada come. A sequência alterna planos médios de ambos os personagens e closes de Tony, e a música extradiegética realça o tom melodramático:

Mãe: Você fica na rua até tarde, bebendo vinho...

Tony: Me deixe em paz!

Mãe: Ouça, Antonio. Eu... [chorando, afaga a cabeça de Tony] Tem espaguete para você, no forno. Se melhorar, coma um pouco. Fará bem a você. Você era um bom menino, Antonio. Lembra-se de quando cantava na igreja? No coral do padre McNeil? [close em Tony, cuja face torna-se serena com a lembrança] Todo de branco. Lembra-se?

Tony: Padre McNeil...

Mãe: A igreja era linda. [olhando para cima] Você era pequeno com cabelos longos. Velas grandes. Flores. Lembra-se, Antonio? [afaga o filho e dirige-se à porta da sala]

Tony: [corre atrás da mãe] Não me abandone, mãe! Não precisa ir agora, não é? [chorando] Pode ficar um pouco mais? Por favor, não vá. Por favor. [abraçam-se e a música aumenta o volume]

Mãe: Antonio, meu filho. Eu fico, Antonio. Meu menino. [choram juntos, abraçados] 
Tony: Vou ficar bem. É melhor você ir, ouviu? Vá embora. Cuide-se. Mande um beijo meu à Srta. Manccia. ${ }^{26}$

O tom melodramático da cena acentua os valores morais cristãos - com o apelo da mãe aos tempos em que Tony frequentava a igreja e era um bom menino -, mas também há uma forte presença do apego ao núcleo familiar. No romance, essa questão específica é tratada de maneira diferente. Tony passa pelo mesmo dilema e procura a ajuda da mãe; essa, no entanto, não é compreensiva como no filme, e se diz cansada do filho, que "vive bêbado como o pai" 27 . O único refúgio de Tony no romance é num breve encontro por acaso com o Padre McConagha:

Tony não conseguia olhar para o Padre McConagha e continuava mexendo e olhando para o seu chapéu. Padre McConagha conversou com ele por alguns minutos sobre as recompensas da honestidade e sobre a felicidade advinda do trabalho feito com fé, e então disse:

“Antonio, um dia seu pai me pediu para cuidar de você. Seu pai era um bom homem, mas era fraco. Lembre-se, Antonio, se você tiver qualquer problema, você deve me procurar." 28

Embora a referência à moral religiosa seja na essência a mesma no filme e no romance, os efeitos provocados são distintos. O diretor de Little Caesar se aproveita dos recursos cinematográficos (como o uso da música, os movimentos de câmera e a direção de atores) e de sua liberdade na adaptação do roteiro para intensificar o moralismo conservador cristão e uni-lo ao apego à família com uma boa dose de melodrama, ao mesmo tempo em que demonstra a inutilidade da tentativa do apelo à religiosidade e ao núcleo familiar, como o fim trágico de Tony deixa evidente.

Esse movimento da narrativa tem o claro objetivo de estabelecer uma distinção entre Tony e Rico. Enquanto o primeiro se arrepende de seus pecados e tem um passado ligado à religião e à obediência civil, o segundo é um assassino que se destaca pela sua habilidade com armas de fogo. Uma possível identificação do espectador com Tony e suas virtudes, entretanto, não é imediata, pois ele é caracterizado como um personagem que se acovarda e

\footnotetext{
${ }^{26}$ As citações dos diálogos de Little Caesar têm como base as legendas do DVD.

${ }^{27}$ Cf. Burnett, W. R. Little Caesar. New York: The Dial Press, 1958, p. 72.

${ }^{28}$ Ibidem, p. 72-73.
} 
tenta trair seus companheiros; Rico, por sua vez, tem uma personalidade mais marcante, é audacioso, fiel à sua gangue e focado em seus objetivos. Cria-se, então, uma contradição:

\begin{abstract}
Espera-se que o self-made man aja de maneira implacável, aceite o poder, seja dinâmico, mas esse comportamento é contrário à ética protestante vigente. A sociedade dá valor à ambição impiedosa, mas insiste que nós amemos o próximo. (...) Torcemos pelo gângster tanto quanto nos sentimos gratificados quando ele é baleado. $^{29}$
\end{abstract}

Podemos concluir, a partir da avaliação do crítico Stuart M. Kaminsky, que a ideologia do self-made man é boa para os negócios e ruim para a sociedade. Do ponto de vista ético há, dessa maneira, uma contradição entre os valores defendidos pela sociedade e aqueles sustentados pelo mundo dos negócios. Ao mesmo tempo em que Little Caesar nos permite enxergar tal contradição ao mostrar que o modelo do self-made man norte-americano se encaixa na caracterização de um gângster, também é possível dizer que a livre iniciativa utilizada por Rico como princípio para ascensão social é idêntica à de qualquer homem de negócios. Logo, podemos desfazer a contradição ao substituir "sociedade" por "crime organizado": a ideologia do self-made man é boa tanto para os negócios quanto para o crime organizado. O paralelismo entre crime e negócios e a crítica em torno das semelhanças entre as duas esferas é recorrente em diversos momentos da narrativa de Little Caesar, conforme veremos ao longo de nossa análise.

Voltando à questão do conflito entre Tony e Rico, o desenrolar do enredo nos mostra que a tensão entre os personagens é resolvida por meio da violência: ao saber que o primeiro está prestes a se confessar com o Padre McNeil - o que representaria um risco para o futuro dos negócios da gangue -, Rico decide ir atrás de Tony e mata-o na escadaria da igreja (Figura 2). Na avaliação do crítico Robert Rice,

quando faz parte dos "negócios criminosos", a violência normalmente se sobrepõe aos "negócios" na opinião pública, e quando não faz parte (...) o crime em si não tem o apelo emocional de um assassinato a sangue frio ou um sequestro. No entanto, se a violência de Al Capone for analisada sob o ponto de vista interno de suas operações em vez de externo, observa-se algo curioso. Diferentemente de sua aparência externa, a violência se equipara à ferramenta básica que homens de negócios usam diariamente: a lei. Desse ponto de vista, a lei também é violência,

${ }^{29}$ Kaminsky, S. M. Little Caesar and its Role in the Gangster Film Genre. In: Philadelphia: Journal of Popular Film, Vol. 1, Iss. 3, 1972, p. 217. 
violência petrificada, certamente, violência sedimentada em âmbar, mas, ainda assim, violência. A lei só é cumprida quando policiais armados estiverem por perto; eles podem não ser chamados, mas sua presença é subentendida toda vez que um juiz assina uma decisão, ou o sistema legislativo aprova um projeto de lei. Recorrer à lei é o recurso que todo homem de negócios utiliza para se proteger contra seus concorrentes ou associados. É um recurso, obviamente, que nenhum criminoso pode usar. Dessa maneira, em vez de chamar um advogado, ele chama um capanga. Em outras palavras, quando um gângster recorre à violência, ele ainda está fazendo negócios. ${ }^{30}$

Além do caráter violento dos negócios, chama-nos a atenção o fato de Rice destacar a impossibilidade de o criminoso recorrer à lei. A história do crime organizado, entretanto, nos mostra que tal recurso sempre foi utilizado de uma maneira ou de outra: do suborno a policiais e juízes à contratação de advogados, a lei e seus agentes são muitas vezes cúmplices das atividades ilegais no gangsterismo. Essa cumplicidade não ocorre especificamente em Little Caesar, uma vez que o sargento Flaherty (Thomas E. Jackson) é caracterizado como um policial implacável e, aparentemente, incorruptível. Contudo, o tema é posteriormente utilizado em obras como O Poderoso Chefão (Francis Ford Coppola, 1972) e Force of Evil (Abraham Polonsky, 1945), nos quais os advogados são parte integrante das organizações criminosas.

Retornando ao tema da violência em Little Caesar, vale ressaltar que o assassinato de Tony e a frieza com que Rico o comete não desfazem por completo a contradição apontada anteriormente entre o amor ao próximo e a ambição impiedosa. Dentro da moralidade cristã definida pela epígrafe bíblica do filme, matar o próximo é um pecado contra o quinto mandamento. Entretanto, sob a frieza da lógica corporativa, a morte de Tony significa a sobrevivência do próprio Rico e dos negócios da gangue.

\footnotetext{
${ }^{30}$ Rice, R. The Business of Crime. London: Victor Gollancz LTD, 1956, p. 15-16.
} 


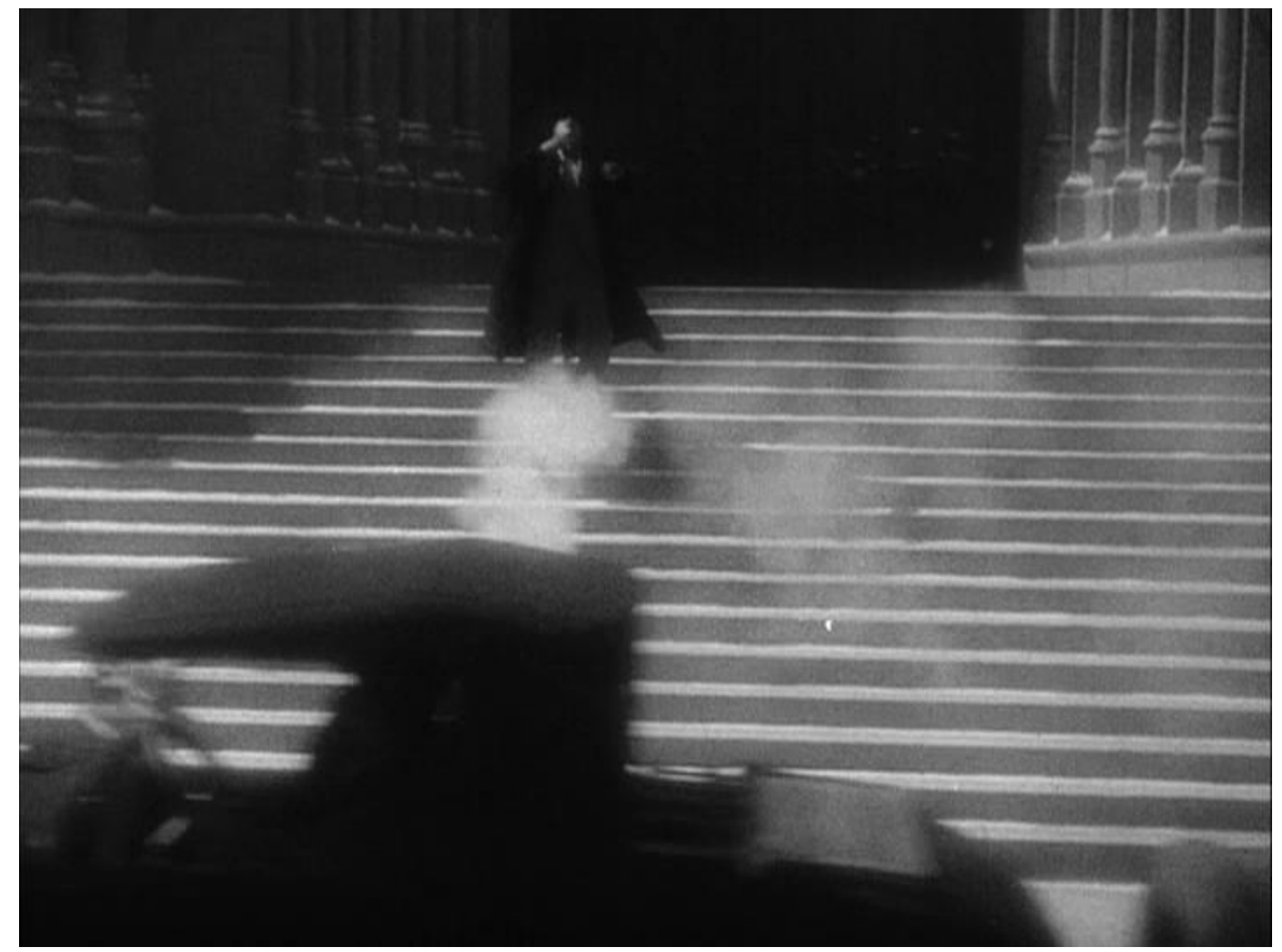

Figura 2 - Tony é morto na escadaria da igreja.

A naturalidade com que a violência é tratada pelos personagens se dá de maneira mais evidente na sequência seguinte ao assassinato de Tony, que mostra em tom jocoso o cortejo fúnebre que os próprios companheiros de gangue oferecem em homenagem ao colega morto por Rico. Enquanto Scabby (Henry Sedley), Killer Peppi (Noel Madison) e Sam Vettori (Stanley Fields), admiram o tamanho da coroa de flores oferecida por Rico, esse último e Otero (George E. Stone) lamentam que Tony não poderá comparecer ao banquete daquela noite.

Pode-se dizer que o assassinato de Tony é um entre muitos erros táticos que o protagonista comete ao longo da narrativa. Little Caesar apresenta um ponto de vista crítico em relação às ações de Rico porque demonstra o acúmulo desses erros - trair seus irmãos de classe, privilegiar a ação individual, aderir à ideologia pequeno burguesa, etc. -, que, em determinados casos, são condenáveis tanto do ponto de vista da moralidade cristã, como do ponto de vista político.

Contudo, a persistência do elemento religioso em meio ao cenário urbano norteamericano pode ser lida, sob o ponto de vista da esquerda, como um resíduo regressivo na 
vida da classe trabalhadora, pois funciona como substituto das relações sociais produtivas e emancipatórias. Uma vez que o tema dos negócios está sempre em jogo no filme, o desejo da mãe pelo regresso do filho ao ambiente religioso acaba por excluir Tony do mercado de trabalho - e, portanto, do embate das forças produtivas.

\section{Hollywood pre-Code e o subtexto homossexual}

Após a epígrafe bíblica, temos a primeira cena do filme, que mostra um assalto a um posto de combustível (Figura 3). A câmera mostra, em plano geral, um carro preto parando em frente às bombas de gasolina do posto. Enquanto o frentista sai de dentro da loja para atender os clientes, o passageiro do carro sai rapidamente com uma arma na mão. $\mathrm{O}$ olhar atento identifica que o assaltante é interpretado pelo ator Edward G. Robinson, mas a movimentação é muito rápida, e a posição da câmera não privilegia essa identificação inicial do personagem de Robinson como o assaltante. Logo que sai do carro, o criminoso anuncia o assalto para o frentista, que levanta os braços e é empurrado para dentro da loja. Em seguida, o criminoso apaga todas as luzes do posto. Não há qualquer diálogo ou movimento de câmera, e a iluminação da cena é precária, sendo possível identificar somente as silhuetas dos objetos em cena. No entanto, assim que as luzes são apagadas, é possível claramente ouvir o som de três tiros e, logo depois, o tilintar de uma caixa registradora sendo aberta. Há um curto período de silêncio. Em seguida, o assaltante sai da loja, entra no carro, e segue seu caminho.

A câmera estática e em plano geral, somada à epígrafe retirada da Bíblia, estabelece, desde o início da narrativa, um ponto de vista bem definido, que visa ao julgamento das ações dos personagens com um olhar (ao menos a princípio) distanciado e sob a perspectiva da moral conservadora cristã. Tal julgamento terá como alvo principal as ações do protagonista, como deixa claro o título do filme. 


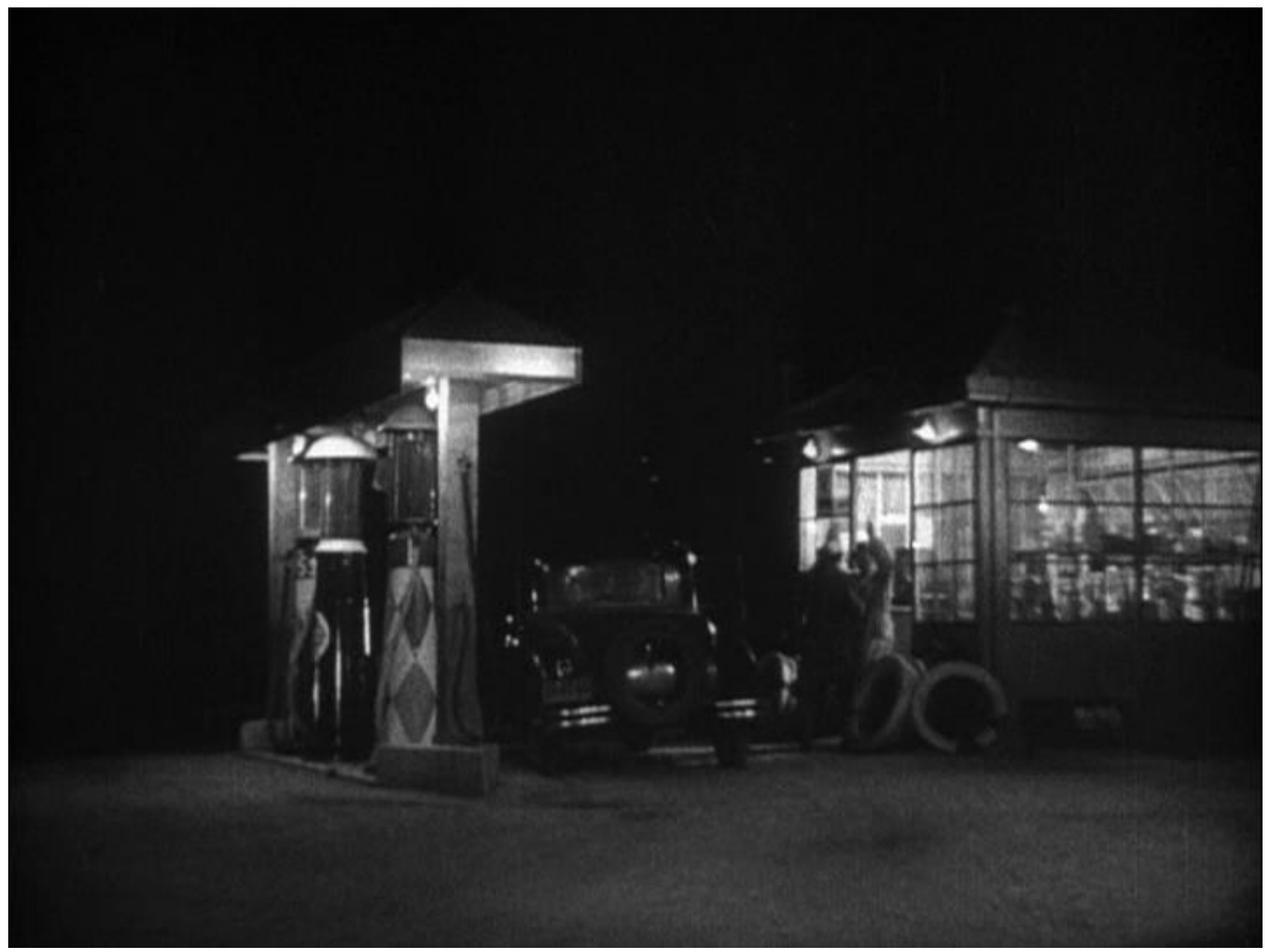

Figura 3 - $\mathrm{O}$ assalto ao posto de gasolina.

A escolha pelo plano geral e a dificuldade de identificação dos personagens devido à iluminação precária, além da ausência de diálogos e dos nomes dos personagens na cena, vão ao encontro da declaração de W. R. Burnett sobre a caracterização de Rico como um tipo, que é

caracterizado pelo fato de que nele convergem, em sua contraditória unidade, todos os traços salientes daquela unidade dinâmica na qual a autêntica literatura reflete a vida; nele, todas as contradições - as mais importantes contradições sociais, morais e psicológicas de uma época - se articulam em uma unidade viva. ${ }^{31}$

Ao optar pelo plano geral, o diretor insere o assaltante e o frentista num contexto específico, mostrando a relação entre os dois personagens e o próprio ambiente ao seu redor. $\mathrm{O}$ espectador é, dessa maneira, instigado a se perguntar a respeito da função dos personagens

${ }^{31}$ Lukács, G. Introdução aos escritos estéticos de Marx e Engels. In: Cultura, arte e literatura: textos escolhidos/Karl Marx e Friedrich Engels. São Paulo: Expressão Popular, 2010, p. 27 
na narrativa. No caso do assaltante, sua função é evidenciar o contexto violento em que a narrativa se desenrolará.

Um segundo ponto que merece destaque nessa cena é a evidência do uso do som. $\mathrm{O}$ diretor Mervyn LeRoy faz questão de ressaltar a técnica sonora ao sincronizar o ruído dos tiros com o momento em que há menos luz em cena. Para a crítica Fran Mason, a adição do som foi determinante para a evolução dos filmes de gângster, pois

\footnotetext{
os sons diegéticos da linguagem do gângster, tiros e o derrapar dos pneus, assim como os ruídos característicos do ambiente urbano, evocavam de modo mais eloquente o mundo moderno habitado pelo gângster do que as favelas escuras do gângster do cinema mudo. (...) Filmes mudos tinham armas, mas não conseguiam representar efetivamente o poder ou a ameaça do gângster porque eles só podiam mostrar que um tiro havia sido dado com a imagem da fumaça saindo do cano de uma arma. ${ }^{32}$
}

Em outras palavras, o advento do som no cinema possibilitou ao espectador dos filmes de gângster uma relação sensorial com o universo do crime que não era possível no cinema mudo.

Em terceiro lugar, podemos destacar também a escolha para o início da narrativa. Assim que o filme começa, o protagonista comete um latrocínio. Outros filmes de gângster do período (como Scarface e White Heat) também começavam com assassinatos. Tal procedimento estabelece, a partir de Little Caesar, um dos genre motifs dos filmes de gângster: o de que, uma vez dentro do mundo do crime, não há retorno. O destino de Rico "é selado pela convicção moral da plateia e do código dos anos 1930 (que um criminoso precisa ser punido pelos seus crimes)". ${ }^{33} \mathrm{O}$ mesmo tema é reiterado no filme quando Joe explica a Olga (Glenda Farrell) que "uma vez na gangue... você sabe. (...) Nunca vi ninguém conseguir sair".

O modo como essa primeira cena de Little Caesar foi registrada também pode ser considerado uma estratégia deliberada de enfatizar a hostilidade do ambiente e, simultaneamente, ter a cena aprovada pela censura da época. Os produtores do filme sabiam

\footnotetext{
${ }^{32}$ Mason, F. American Gangster Cinema - from Little Caesar to Pulp Fiction. New York: Palgrave Macmillian, 2002, p. 4.

${ }^{33}$ Kaminsky, S. M. Little Caesar and its Role in the Gangster Film Genre. In: Philadelphia: Journal of Popular Film, Vol. 1, Iss. 3, 1972, p. 214.
} 
que sugerir um assassinato em vez de filmá-lo de forma explícita aumentava as chances de a cena ter a simpatia dos censores.

Little Caesar pertence a um período dentro da historiografia do cinema norteamericano marcado pelo surgimento, em 1930, do Production Code (Código de Produção), um documento com uma série de diretrizes que pretendiam estabelecer normas de conduta para as produções hollywoodianas. A violência dos filmes de gângster e o erotismo das fitas estreladas por atrizes como Mae West ou Marlene Dietrich eram os principais alvos do código, mas todos os filmes produzidos em Hollywood precisavam passar pelo crivo de censores. A extensão do poder do código, contudo, é tema de debate entre os historiadores. O estudo das raízes históricas do Production Code e das mudanças realizadas em Little Caesar nos ajudam a entender melhor esse debate e a compreender que, além do aspecto moral, diversos interesses políticos e econômicos orbitavam a prática da censura em Hollywood.

A preocupação com a censura cinematográfica nos EUA data do início do século $\mathrm{XX}$, com a popularização do cinema como forma de entretenimento no país. As primeiras normas municipais para o conteúdo dos filmes foram criadas em 1908. Tal controle surgiu como consequência do ambiente onde os filmes eram exibidos - "espaços abafados e escuros, onde as crianças, principalmente, seriam influenciadas pelo mal nas condições de exibição desses filmes" 34 . Além disso, ir ao cinema

tornou-se rapidamente um ponto de encontro de adultos solteiros e, como resultado, códigos de conduta moral vitorianos eram frequentemente desafiados nos mezaninos dos cinemas ao redor do país. O que lá podia ser feito no escuro (e ostensivamente em público) parecia sugerir que o problema não era somente o conteúdo dos filmes, mas também a experiência cinematográfica em si. ${ }^{35}$

A pressão pela regulamentação dos filmes logo se ampliou para o âmbito estadual. Em 1915, a Mutual Film Corporation, uma produtora e distribuidora de filmes, acusou a Industrial Commission of Ohio - conselho estadual de censura cinematográfica do estado de "impedir injustamente o comércio interestadual e violar o direito à liberdade de expressão

\footnotetext{
${ }^{34}$ Maltby, R. Censorship and Self-Regulation. In: Nowell-Smith, G. (ed.). The Oxford History of World Cinema. New York: Oxford University Press, 1996, p. 253.

${ }^{35}$ Lewis, J. Hollywood v. Hardcore: how the struggle over censorship saved the modern film industry. New York: New York University Press, 2000, p. 89.
} 
garantidos pelas leis estaduais e pela constituição dos Estados Unidos"36. De maneira unânime, a Suprema Corte decidiu a favor da Industrial Commission of Ohio ao estabelecer uma distinção entre entretenimento e arte - assim como entretenimento e informação - e recusou ao cinema o mesmo direito à liberdade de expressão que a literatura e a imprensa possuíam. Segundo a sentença desse julgamento,

não se pode ignorar o fato de que a exibição de filmes nada mais é do que um negócio criado e conduzido visando o lucro, como outros espetáculos, e não deve ser considerado, e nem se destina a ser considerado pela constituição de Ohio como parte da imprensa do país ou como órgãos de opinião pública. Eles [os filmes] são meras representações de eventos, de ideias e sentimentos publicados e conhecidos, sem dúvida úteis e interessantes, mas, como dissemos, capazes de propagar o mal, principalmente devido à sua atratividade e forma de exibição. ${ }^{37}$

A sentença da Suprema Corte nos chama a atenção por três pontos. O primeiro deles é a clareza sobre o caráter de mercadoria da exibição dos filmes, acima de qualquer valor artístico alegado pela Mutual Film Corporation. Em segundo lugar, podemos destacar o conceito de "mal" utilizado no texto. De acordo com o historiador Jon Lewis,

\footnotetext{
a histeria da retórica quanto ao potencial maligno do cinema estava fundamentada muito mais no medo, desconfiança e na aversão da Corte ao público espectador imigrante pobre do que na preocupação sincera sobre o conteúdo de filmes específicos $^{38}$.
}

Em terceiro lugar, ressaltamos a consciência da Suprema Corte de que o perigo do cinema está na sua "forma de exibição".

A negação do direito de liberdade de expressão à Mutual Film Corporation tem um caráter político por dois motivos. Primeiro, porque, ao estabelecer uma distinção entre o cinema e outras formas artísticas, como a literatura, a Suprema Corte reconhece a transformação da função social da arte provocada pelo cinema que, por meio da reprodutibilidade técnica, é capaz de atingir as massas e, com sua força de persuasão, influenciá-las; segundo, porque a sentença define arbitrariamente tanto quem é prejudicado pelo conteúdo dos filmes como o que é capaz de "propagar o mal". São excluídos desse

\footnotetext{
${ }^{36}$ Lewis, J. Hollywood v. Hardcore: how the struggle over censorship saved the modern film industry. New York: New York University Press, 2000, p. 90.

${ }^{37}$ Ibidem, p. 91. Grifos nossos.

${ }^{38}$ Idem.
} 
processo os produtores, atores, diretores, e trabalhadores da indústria cinematográfica em geral. Assim como em outras esferas artísticas, a censura no cinema é, desde seu início, um desdobramento do embate entre o desenvolvimento das forças produtivas e a posse dos meios de produção. Cada corte feito pela censura representa uma derrota dos trabalhadores nessa luta.

Em 1921 foi a vez do estado de Nova Iorque aprovar um projeto de lei que estabelecia a censura sobre os filmes. Tal projeto coincidiu com ações antitruste do Federal Trade Commission - que ameaçavam a integração vertical da produção, distribuição e exibição de filmes ${ }^{39}$-, além de ameaças de investigações sobre as atividades políticas dentro da indústria cinematográfica pelo Comitê Judiciário do Senado. Diante desse cenário, foi criada a Motion Picture Producers and Distributors of America (MPPDA) em março de 1922, sob o comando de Will Hays - ex-presidente do Comitê Nacional Republicano e figura importante na campanha eleitoral de 1920 do presidente Warren Harding (1921-1923). ${ }^{40}$

A criação da MPPDA tinha dois objetivos distintos. O primeiro era instaurar uma autocensura dentro da indústria e impedir o avanço da censura estadual, que representaria um controle externo à produção dos filmes. $\mathrm{O}$ segundo era reestruturar internamente a indústria hollywoodiana, que se encontrava naquele momento abalada tanto pela ameaça das ações antitruste, quanto pela disputa entre distribuidores e exibidores pelo monopólio do mercado. Tal disputa minou a confiança de Wall Street no poder de gerenciamento interno da indústria cinematográfica e colocou em risco sua saúde financeira. Outro fato importante nessa equação foram os escândalos envolvendo artistas de Hollywood no início dos anos $1920^{41}$, que também mancharam a imagem de Hollywood como um lugar propício a desvios de conduta e a extravagâncias financeiras. Hays convenceu os executivos hollywoodianos de que era preciso um gerenciamento mais eficiente das relações públicas da indústria a fim de reestabelecer a imagem de Hollywood como um entretenimento "inofensivo" perante o

\footnotetext{
39 “Ao longo das décadas de 1920 e 1930, a indústria encontrava-se sob o constante bloqueio de legislações municipais e estaduais, propostas por políticos que viram nas fabulosas riquezas de Hollywood uma potencial fonte de receitas. A MPPDA manteve uma extensa rede de alianças políticas para evitar a passagem dessas leis, assim como conduziu as relações da indústria com o governo federal e sua política externa em negociações sobre acordos e quotas com outros países." (Maltby, R., Censorship and Self-Regulation. In: Nowell-Smith, G. (ed.). The Oxford History of World Cinema. New York: Oxford University Press, 1996, p. 238)

${ }^{40}$ Ibidem, p. 239.

${ }^{41} \mathrm{O}$ historiador Jon Lewis aponta três grandes escândalos relacionados a artistas de Hollywood nesse período: o estupro e homicídio da atriz Virginia Rappe, cujo principal suspeito foi o comediante Roscoe "Fatty" Arbuckle; o caso não solucionado do assassinato do diretor William Desmond Taylor; e a morte por overdose do ator Wallace Reid. Os três casos tiveram repercussão nacional na imprensa. (Cf. Lewis, J., Hollywood v. Hardcore: how the struggle over censorship saved the modern film industry. New York: New York University Press, 2000, p. 93).
} 
público consumidor e, sobretudo, como um investimento seguro perante Wall Street. Segundo Hays, os filmes deveriam apresentar "não somente um nível satisfatório de entretenimento para os mais diversos espectadores, como também incomodar o mínimo possível as lideranças culturais e legislativas". ${ }^{42}$

A autocensura em Hollywood, entretanto, não foi suficiente para impedir que conselhos municipais e estaduais fossem formados e operassem em cerca de $60 \%$ do mercado interno, além de interferirem em quase todo o mercado externo da indústria. Dessa maneira, a MPPDA representava uma censura adicional, e não substitutiva. ${ }^{43} \mathrm{~A}$ primeira ação efetiva de censura a filmes pela MPPDA só ocorreu dois anos após sua fundação, em 1924, quando foram estabelecidas regras para as escolhas de peças de teatro ou romances a serem adaptados para o cinema. Em 1927 foi estabelecido o primeiro código para a produção de filmes, conhecido informalmente como Don'ts and Be Carefuls e administrado pelo Studio Relations Committee (SRC) dentro da MPPDA. Tal código, no entanto, era visto pela indústria cinematográfica somente como uma série de recomendações que poderiam ser ignoradas sem consequências. Somente no início de 1930, sob a coordenação de Will Hays e do diretor da SRC, Coronel Jason Joy, além do auxílio de autoridades religiosas, foi redigido um documento denominado Production Code, com uma extensa lista de regras e princípios a serem seguidos na produção de filmes. Entre os seus Princípios Gerais, o Código exigia que a) nenhum filme deveria diminuir os padrões morais dos seus espectadores, ou seja, o público não deveria sentir simpatia pelo crime, pelo mal ou pelo pecado; b) os filmes deveriam apresentar padrões morais corretos; c) leis, naturais ou humanas, não deveriam ser ridicularizadas e nem dever-se-ia estimular a violação das mesmas. ${ }^{44}$

Há uma divergência na fortuna crítica sobre os filmes produzidos no início da década de 1930 a partir da criação do Production Code. Alguns historiadores e críticos, como Robert Sklar e Thomas Doherty, dividem a história de Hollywood nesse período em pre-Code e post-Code, ou seja, do comprometimento da MPPDA a respeitar o Production Code em março de 1930 a julho de 1934, quando a MPPDA, ao ceder à pressão de grupos religiosos que ameaçavam boicotar os filmes, delegou a aplicação do Código ao Production Code Administration (PCA), sob o comando de Joseph Breen. Segundo esses historiadores, nesse intervalo de quatro anos o compromisso da MPPDA com o Código era meramente verbal,

\footnotetext{
${ }^{42}$ Maltby, R., Censorship and Self-Regulation. In: Nowell-Smith, G. (ed.). The Oxford History of World Cinema. New York: Oxford University Press, 1996, p. 239.

${ }^{43}$ Idem.

${ }^{44}$ Ibidem, p. 241-242.
} 
pois nada a obrigava a obedecê-lo de maneira formal. Nas palavras de Robert Sklar, na "primeira metade da Grande Depressão, os produtores de Hollywood perpetraram uma das maiores contestações aos valores tradicionais na história do entretenimento comercial de massa" ${ }^{25}$. Thomas Doherty, por sua vez, é menos comedido nas palavras e afirma que

por quatro anos, os mandamentos do Código foram violados impunemente com criatividade em uma série de filmes excêntricos. Mais descontrolados, lascivos, subversivos, e simplesmente bizarros do que as produções seguintes, eles tinham o aspecto de filmes de Hollywood, mas os valores morais estavam tão desequilibrados que os filmes pareciam importados de um universo paralelo. ${ }^{46}$

Enquanto Doherty e Sklar veem entre os filmes produzidos antes e depois de 1934 uma ruptura, o historiador Richard Maltby enxerga um processo. O equívoco na avaliação de Sklar e Doherty sobre o chamado período pre-Code, de acordo com Maltby, pode ser resumido em uma pergunta:

Por que uma indústria que se autointitulava o quarto maior empreendimento capitalista nos Estados Unidos, ligada de maneira complexa ao capital financeiro de Wall St., produziria "uma das maiores contestações aos valores tradicionais na história do entretenimento comercial de massa" no momento de maior instabilidade social e política que os EUA já viveram ${ }^{47}$

As razões para que alguns historiadores façam a divisão entre Hollywood pre e postCode, segundo Maltby, são diversas. Uma delas é o recorte do corpus para um número muito limitado de obras - cerca de vinte e cinco filmes, ou um por cento de toda a produção cinematográfica norte-americana do período. Um segundo ponto está no valor gerado pela reclassificação de um material do passado de Hollywood para suprir as necessidades mercadológicas do presente. "Sob essa nova aparência, o Pre-Code Cinema foi reinventado

\footnotetext{
${ }^{45}$ Sklar, R. Movie-Made America: A Cultural History of American Movies. New York: Random House, 1975, p. 175

${ }^{46}$ Doherty, T. P. Pre-code Hollywood: sex, immorality, and insurrection in American cinema, 1930-1934. New York: Columbia University Press, 1999, p. 2.

${ }^{47}$ Maltby, R. More Sinned Against than Sinning: The Fabrications of "Pre-Code Cinema". In: Senses of Cinema, Issue 29. Melbourne: RMIT University, 2003. Disponível em http://sensesofcinema.com/2003/ feature-articles/pre code cinemal. Acessado em 09/01/2015.
} 
pelos críticos do gênero, assim como 'filme noir' ou 'melodrama', sem qualquer raiz em práticas da indústria" ${ }^{48}$.

Uma terceira razão para o surgimento dessa classificação está no fato de críticos como Robert Sklar terem feito sua avaliação na década de 1970, ainda sem terem acesso aos arquivos do Production Code Administration, que ficaram disponíveis aos pesquisadores somente uma década depois. ${ }^{49}$ Trata-se de um arquivo de mais de trinta mil páginas, organizadas cronologicamente por filme e disponíveis em formato digital ou microfilme, que documentam quase quarenta anos em que o código foi aplicado em Hollywood. ${ }^{50}$

A leitura dos arquivos do PCA sobre Little Caesar esclarece alguns elementos da discussão em torno da censura em Hollywood no início da década de 1930. Compostos basicamente por correspondências (cartas e telegramas) e documentos da MPPDA, esses arquivos mostram que o Studio Relations Committee, na figura principalmente de Jason Joy, funcionava como um mediador entre os interesses da Warner Bros. e dos conselhos de censores dos estados norte-americanos e de outros países. Nas suas cartas, Joy age como um defensor de Little Caesar, da integridade da obra, e de seus produtores. Ele parabeniza Hal B. Wallis, produtor da Warner Bros., por Little Caesar ter sido aprovado nos conselhos de censura dos estados da Virgínia e de Kansas, por exemplo.

Ao saber que o filme fora rejeitado por conter uma “indesejável história de crime e extorsão" na província da Colúmbia Britânica, no Canadá, Joy dirige-se a John A. Cooper, do conselho de censores de Vancouver, e faz um desabafo:

Parece-me muito ruim permitir aos censores rejeitar ou mutilar filmes que são consciente e sinceramente feitos dentro do Código. No último ano, todos os grandes estúdios em Hollywood fizeram esforços em retirar dos filmes quaisquer elementos que pudessem ser considerados ofensivos ao bom gosto na avaliação de pessoas com inteligência mediana. Ao longo dos primeiros seis ou sete meses dessa empreitada, os censores, com uma ou duas exceções (notadamente a Colúmbia Britânica), entenderam o espírito do Código, e nos deram o apoio que

\footnotetext{
${ }^{48}$ Maltby, R. More Sinned Against than Sinning: The Fabrications of "Pre-Code Cinema". In: Senses of Cinema, Issue 29. Melbourne: RMIT University, 2003. Disponível em http://sensesofcinema.com/2003/ feature-articles/pre code cinema/. Acessado em 09/01/2015.

${ }^{49}$ Idem.

${ }^{50}$ Cf. Hollywood, Moral Censorship, and the Motion Picture Production Code, 1927-1968. Disponível em http://gdc.gale.com/archivesunbound/hollywood-moral-censorship-and-the-motion-picture-production-code1927-1968/?searched=production+code\&advsearch=exactphrase\&highlight=ajaxSearch highlight+ajax Search highlight1. Acessado em 11/01/2015. O acesso completo aos arquivos foi feito através da Universidade da Pensilvânia.
} 
tornou possível manter o controle da produção sob o Código. Entretanto, nos últimos meses, os censores regressaram à sua postura minuciosa, estreita, insignificante e escrutinadora, com seus olhos tão firmemente atentos a pequenos detalhes que eles não percebem o filme como um todo, e julgam-no sob esse olhar. O resultado inevitável disso será a ruína do Código, porque nossa equipe dirá que é inútil tentar produzir filmes sob a atual forma de censura, então por que não colocar tudo de censurável que for possível imaginar, esperando que as partes essenciais não sejam cortadas. Esse pensamento já está tomando forma por aqui e, a não ser que você me ajude, do ponto de vista canadense, e de outros em nosso país, eu não posso continuar responsável pelo produto. ${ }^{51}$

De acordo com os arquivos do PCA, Little Caesar também foi rejeitado na Austrália e em outras duas províncias canadenses (Alberta e Nova Scotia). Nos estados de Ohio, Pensilvânia, Nova Iorque, Massachusetts e Maryland, foram exigidos cortes para que a exibição fosse autorizada. É possível notar a preocupação do conselho de censores de Nova Iorque, por exemplo, com o registro do modus operandi de uma gangue, especialmente em duas cenas (Figura 4): no roubo ao Bronze Peacock - em que a sequência das cenas destaca a precisão do horário combinado para o roubo, a movimentação dos gângsteres e a rapidez da operação - e na invasão da gangue ao escritório de Arnie Lorch (Maurice Black) - as cenas destacam a capacidade de Rico delegar funções a cada um dos capangas, além da ação coordenada para enganar os seguranças de Little Arnie, e a forma como esses são subjugados. ${ }^{52}$

\footnotetext{
${ }^{51}$ Carta de Jason Joy a John A. Cooper. 21 de fevereiro de 1931. In: Little Caesar files. History of Cinema, Series 1, Hollywood and Production Code Administration. Herrick Library. Archives Unbound, p. 35. Disponível em http://proxy.library.upenn.edu:3437/gdsc/i.do?\&id=GALE\%7CSC5106190494\&v=2.1\&u =upenn_main\&it=r\&p=GDSC\&sw=w\&viewtype=fullcitation. Acessado em 11/01/2015.

${ }^{52}$ Carta de Jason Joy a Harry Rapf. 12 de fevereiro de 1931. Ibidem, p. 29.
} 

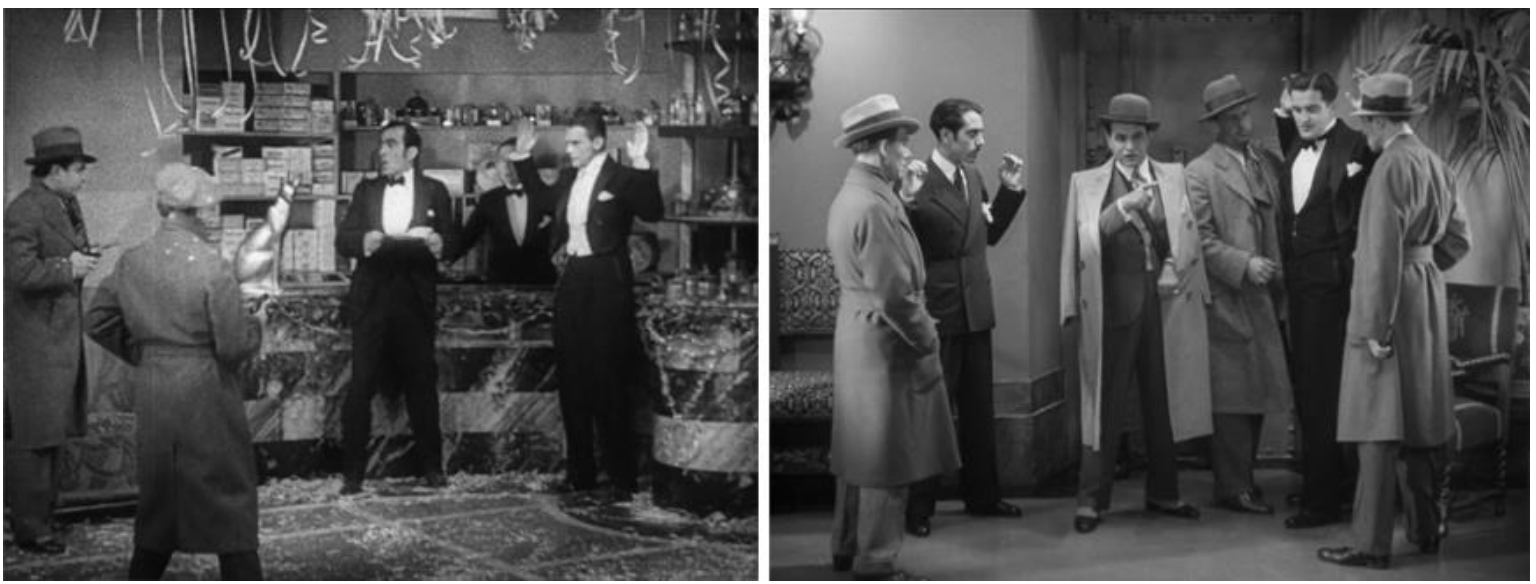

Figura 4 - Cenas censuradas pelo estado de Nova Iorque.

O conselho de censores da Pensilvânia, por sua vez, solicitou a retirada de praticamente todas as cenas com armas de fogo do filme, a não ser a cena final em que o policial Flaherty empunha uma metralhadora e atira em Rico:

7 de novembro de 1930

Conselho de Censores da Pensilvânia

Rolo 1: Cenas do homem parado na porta com as mãos para cima e entrando na porta.

Rolo 3: Cenas dos homens apontando armas para outras pessoas no bar.

Rolo 4: Cenas de Rico atirando de dentro do carro.

Rolo 5: Cenas de tiros sendo disparados de dentro de um caminhão; cenas do homem apontando a arma para outra pessoa do lado de fora do bar, com fala emitida por Pepi: "Vamos, mãos para cima"; cenas do homem apontando a arma para outra pessoa dentro do bar, com fala emitida por Pepi: "Vamos, mãos para cima."; fala emitida por Otero: "Vamos, para cima, seu...",53

Ao tentar defender a integridade de Little Caesar perante a censura nova-iorquina, Jason Joy argumenta que

a descrição das ações ilegais dos gângsteres em Little Caesar é necessária a fim de que o público seja capaz de entender por quais ações os personagens estão sendo punidos e, dessa maneira, ter a oportunidade de comparar a lucratividade dos atos com a punição recebida. (...) quanto mais horríveis e implacáveis forem

\footnotetext{
${ }^{53}$ Carta de Jason Joy a Harry Rapf. 12 de fevereiro de 1931. In: Little Caesar files. History of Cinema, Series 1, Hollywood and Production Code Administration. Herrick Library. Archives Unbound, p. 30. Disponível em $\quad$ http://proxy.library.upenn.edu:3437/gdsc/i.do?\&id=GALE\%7CSC5106190494\&v=2.1\&u =upenn main\&it=r\&p=GDSC\&sw=w\&viewtype=fullcitation . Acessado em 11/01/2015.
} 
representadas as ações criminosas desses gângsteres na tela, mais contundente será a reação contra homens desse tipo e o crime organizado em geral. ${ }^{54}$

A brutalidade e a violência do filme de gângster, sob a perspectiva de Joy, eram imprescindíveis para que os espectadores pudessem ser moralmente instruídos da maneira correta. A censura estaria "destruindo o valor moral do filme como um todo ao deixar na mente do público a impressão de que, no fim das contas, esses homens não fizeram o suficiente para merecer o final infeliz" ${ }^{55}$.

Com base na nossa pesquisa, é possível tirar algumas conclusões sobre a censura em Hollywood no início da década de 1930. A primeira delas é desfazer o mito de que a censura dentro da indústria cinematográfica está relacionada somente à pressão de alguns grupos religiosos e conservadores que queriam eliminar dos filmes temas "moralmente questionáveis". Tal conservadorismo foi apenas um dos elementos que motivaram a criação do Código, o qual, num âmbito mais amplo, nada mais era do que uma tentativa de acalmar os ânimos de Wall Street e, dessa maneira, salvar Hollywood de uma crise financeira.

Em segundo lugar, a leitura dos arquivos do PCA nos mostra que os filmes do início da década de 1930, ao contrário do que afirma Thomas Doherty, estão longe de pertencer a um "universo paralelo" dentro de Hollywood. Havia, sim, a aplicação sistemática de uma censura externa que provocava desde cortes pontuais nas narrativas até sua total rejeição por conselhos de censores estaduais e internacionais. As cartas de Jason Joy nos revelam que o papel do Studio Relations Committee era convencer os censores externos de que a autocensura já havia dado cabo dos eventuais problemas presentes nas narrativas e, portanto, não haveria motivo para efetuar quaisquer cortes. Se considerarmos a lógica da circulação das mercadorias de Hollywood, a censura representava um prejuízo considerável aos estúdios, pois significava mais gastos com pós-produção, atrasos na distribuição e, no pior cenário, a perda de mercados consumidores com a rejeição completa do filme.

Em terceiro lugar, a refutação da teoria do "universo paralelo" nos leva a crer que o rótulo de pre-Code aos filmes do período de 1930-1934 é um exagero. Em termos do gênero gângster, é inegável o contraste entre as narrativas de Little Caesar (1931) e, por exemplo,

\footnotetext{
${ }^{54}$ Carta de Jason Joy a James Wingate. 5 de fevereiro de 1931. In: Little Caesar files. History of Cinema, Series 1, Hollywood and Production Code Administration. Herrick Library. Archives Unbound, p. 19. Disponível em http://proxy.library.upenn.edu:3437/gdsc/i.do?\&id=GALE\%7CSC5106190494\&v=2.1\&u =upenn_main\&it=r\&p=GDSC\&sw=w\&viewtype=fullcitation. Acessado em 11/01/2015.

${ }^{55}$ Idem.
} 
Manhattan Melodrama (W. S. Van Dyke, 1934), cuja principal diferença para o primeiro ciclo de filmes do gênero é a cisão do protagonismo da narrativa entre o gângster Blackie Gallagher (Clark Gable) e o advogado Jim Wade (William Powell). Entretanto, segundo Maltby, a mudança nas narrativas "foi gradual em vez de cataclísmica" 56 , e as escolhas dos roteiristas, além das posteriores trocas de correspondências entre o SRC e os conselhos de censura, demonstram como Hollywood "testou, negociou e reconfigurou os limites das convenções de Hollywood" ${ }^{\prime 57}$ a cada filme produzido. Dessa maneira, as mudanças ocorridas nos filmes nesse período histórico são resultado do desenvolvimento de um "sistema de convenções de representação" construído por meio de experiências e negociações na primeira metade da década e mantido na segunda. ${ }^{58}$ Uma das consequências da evolução desse sistema foi a mudança na linguagem utilizada pelos roteiristas e diretores de Hollywood, que passaram a enunciar determinados conteúdos de forma propositalmente ambígua. Em Little Caesar, é possível identificar tal ambiguidade principalmente na relação entre Rico e Joe.

Desde o início do filme, Rico revela uma ligação muito forte com Joe, e não admite que o parceiro, com quem migrou para o leste em busca de novas oportunidades, tente se afastar do crime - e, consequentemente, de Rico - ao seguir carreira nos espetáculos de dança. O romance de Joe com Olga só faz o ciúme de Rico aumentar ainda mais, o que dá ao filme, de forma inesperada para uma narrativa dessa natureza, um subtexto homossexual. Tal subtexto também se estende à relação entre Rico e Otero: o primeiro é objeto de admiração e desejo do segundo, como é possível observar nas cenas em que somente os dois contracenam.

No último diálogo entre Rico e Joe notamos como se dá esse subtexto entre os dois personagens. Depois de Big Boy (Sidney Blackmer) ter lhe oferecido o lugar de Pete Montana (Ralph Ince) na hierarquia da gangue, Rico convida Joe para uma visita a sua nova casa. A decoração da sala, os gestos, as roupas e até mesmo as falas de Rico imitam às de seu chefe. Joe fica espantado com o luxo do ambiente e elogia Rico pelo seu sucesso. Rico agradece, mas quer que Joe, distante há muito tempo, volte para o seu lado na gangue:

\footnotetext{
${ }^{56}$ Maltby, R. More Sinned Against than Sinning: The Fabrications of "Pre-Code Cinema. In: Senses of Cinema, Issue 29. Melbourne: RMIT University, 2003. Disponível em http://sensesofcinema.com/2003/ feature-articles/pre code cinema/. Acessado em 09/01/2015.

${ }^{57}$ Idem.

58 Idem.
} 


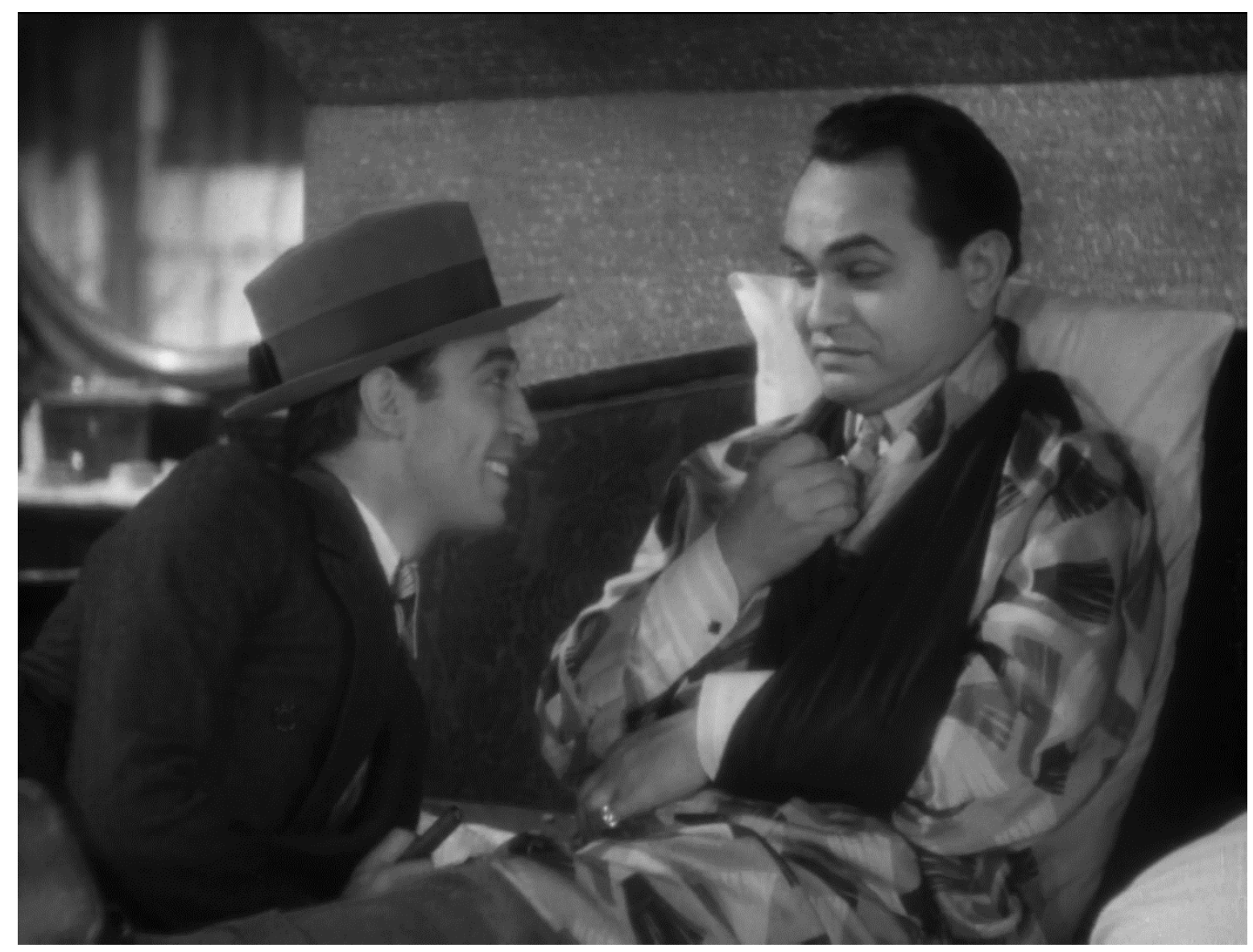

Figura 5 - Otero (esq.) e Rico (dir.) na cama.

Rico: Eu tinha orgulho de você, Joe. Te trouxe pra gangue, dei meu apoio. Mas agora você está virando uma moça.

Joe: A gente precisa voltar a esse assunto? Você não pode simplesmente me esquecer?

Rico: Não, não quero esquecer, Joe. Você é meu parceiro. Começamos juntos, não foi? Precisamos continuar juntos. Em quem mais posso confiar? [colocando a mão no ombro de Joe] Eu preciso de você, Joe. Tenho a maior chance da minha vida. O Big Boy acabou de me oferecer todo o lado norte, mas é muita coisa pra um homem só. Preciso de alguém como você, um cara de confiança.

Joe: Não posso ser esse cara, Rico. Eu caí fora.

Rico: [com indignação] Você não caiu fora. Ninguém me abandona. [agarrando Joe pelo paletó e levantando a voz] Você ainda está na gangue, entendeu? Não importa quantas mulheres estejam grudadas em você. Aquela sua menina pode ir pro inferno! Ela fez você amolecer. Trate de se livrar da Olga.

Joe: Fique longe da Olga.

Rico: [levantando mais a voz] Eu vou me livrar dela! Vou atrás dela! Algum de nós precisa perder, e não serei eu. Há maneiras de fazê-la parar. 
Joe: [levantando a voz] Você está louco! Deixe ela fora disso!

Rico: Acabou pra ela! Sem chance!

Joe: Você está mentindo! Você não teria coragem!

Rico: Não teria? Vou mostrar pra você. [virando as costas para Joe, que o agarra pelo braço]

Joe: Eu a amo. A gente se ama, isso não significa alguma coisa pra você?

Rico: Nada. Menos que nada. Amor. Coisa de maricas! Depois que ela te pegou, você não presta pra mais nada! E você não está fora disso também. Ninguém quer covardes dando com a língua nos dentes...

Joe: Não vou contar nada pra ninguém, se é isso que você tem medo. Acha que eu quero uma corda no meu pescoço?

Rico: Bom, você sabe demais. Não vou correr riscos. Você está junto comigo nisso.

Joe: Não, não estou.

Rico: Tá certo. [colocando a mão na cintura, com ar desafiador] Se você voltar praquela mulher, é suicídio. Suicídio pra vocês dois. [o telefone toca] Fique aqui. [Joe aproveita que Rico sai da sala para fugir]

Na sequência seguinte, Rico e Otero chegam ao apartamento de Joe e Olga. Rico aponta a arma para Joe, mas recua, e Otero resolve atirar, pois diz que Rico é quem "está amolecendo". Rico tenta impedir Otero e o tiro acerta o braço de Joe. Nesse momento, Flaherty chega ao prédio, os gângsteres fogem pela escada de incêndio e, na sequência, Olga delata Rico ao policial. Joe não confirma nem desmente a história, e Flaherty ordena uma busca pelos fugitivos. Enquanto fogem da polícia, Rico diz a Otero: "É isso o que eu ganho por gostar demais de um cara".

Como um gângster, Rico tem a noção de que, dentro do imperativo do mundo dos negócios, não há laços afetivos que justifiquem um recuo. Ele já havia demonstrado essa frieza ao eliminar Tony na escadaria da igreja; entretanto, ao tentar resolver o conflito com Joe, o gângster "amolece”. Dessa maneira, a ambiguidade na relação entre Rico e Joe é crucial para a narrativa de Little Caesar porque ela determina um dos pontos de inflexão da narrativa: por "gostar demais" de Joe, Rico foge da polícia e perde tudo o que havia conquistado.

Vale notar que no romance de W. R. Burnett não há ambiguidades na relação entre os personagens. Joe, que já pertencia à gangue quando Rico se apresenta a Vettori, é o primeiro a ser preso e delata toda a gangue quando é interrogado. Além disso, ao contrário do que ocorre no filme, não há no romance conotação afetiva na admiração que Otero 
demonstra pelo poder de liderança de Rico. Por que, então, criar ambiguidades nas relações entre os personagens ao adaptar o enredo do romance para o cinema? Nossa primeira hipótese é de que a própria elaboração do relacionamento entre Rico e Joe no filme elevou a carga emocional da narrativa, o que certamente foi visto com bons olhos por Hollywood.

A segunda hipótese é de que o modo ambíguo como esse relacionamento se configura foi uma estratégia deliberada dos roteiristas de Little Caesar para testar os limites da censura como parte do estabelecimento de novas "convenções de representação". Pode-se dizer que a estratégia teve sucesso, pois não há nenhuma menção nos arquivos do PCA a qualquer subtexto homossexual que o filme possa ter. Como vimos anteriormente, os censores estavam menos preocupados na relação entre Rico e Joe do que em eliminar do filme as cenas de tiroteio - mais especificamente, com as armas de fogo nas mãos de criminosos. Ainda assim, Little Caesar pode ser considerado uma obra relativamente comedida em termos de violência se comparada a Public Enemy e Scarface, por exemplo, que foram mais radicais no teste à tolerância dos censores.

Segundo Richard Maltby, a preocupação da censura "com a representação da violência (...) era parte de uma inquietação mais abrangente sobre a representação da criminalidade" 59 . Podemos adicionar a essa equação a representação de questões ligadas diretamente aos problemas da classe trabalhadora no período pós-1929, um conteúdo que surge de maneira latente em Little Caesar por força da matéria histórica envolvida nas condições de produção, independente das intenções dos produtores, na forma de homologias estruturais - entre o crime organizado e os negócios, entre o enredo do filme e o funcionamento do capitalismo em momentos de crise, etc. De maneira consciente ou não, a censura acabou por eliminar certas passagens de Little Caesar em que esse conteúdo latente está presente. Um desses momentos é o assassinato de Tony na escadaria da igreja. Já avaliamos a cena sob o ponto de vista da religião, mas há também um componente social e econômico que merece ser desenvolvido.

\footnotetext{
${ }^{59}$ Maltby, R. The spectacle of criminality. In: Slocum, D. J. (ed.) Violence and American Cinema. New York: Routledge, 2001, p. 121.
} 


\section{A crise de 1929 e a concorrência pelo emprego}

A cena do assassinato de Tony na escadaria da igreja pode ser vista de duas maneiras complementares. Por um lado, trata-se da reiteração do ambiente agressivo em que a narrativa se desenrola e, mais especificamente, do estabelecimento do gângster como um indivíduo violento, que impõe respeito por meio do medo. Tal procedimento faz parte do processo de estabelecimento do "sistema de convenções de representação" no cinema para a narrativa do gângster - eliminar um delator já era uma convenção do gênero gângster nos romances, mas era preciso levar essa característica da narrativa para o cinema de maneira aceitável pela censura.

É possível verificar essa preocupação do diretor Mervyn LeRoy na forma como o assassinato é filmado: a exemplo da cena de abertura do filme no posto de gasolina, a câmera não registra Rico puxando o gatilho, pois a composição da cena mostra o carro de Otero e Rico passando em frente à igreja em primeiro plano, enquanto Tony sobe as escadas ao fundo. Além de ouvirmos o estampido do tiro, só é possível ver a fumaça saindo da janela oposta do carro e Tony rolando escada abaixo em seguida. A movimentação é rápida e toda a cena dura poucos segundos; entretanto, mesmo sendo muito econômica em termos de violência - como em boa parte do filme -, tal cena foi alvo dos conselhos de censura de Nova Iorque, Massachusetts, Pensilvânia, e Ohio, que solicitaram sua retirada do filme ${ }^{60}$.

Por outro lado, o assassinato de Tony também pode ser visto como uma homologia estrutural que Little Caesar estabelece entre a eliminação de delatores no crime organizado e a luta intraclasse no período pós-Crise de 1929. Do ponto de vista da classe trabalhadora, um dos efeitos mais danosos do período de Depressão foi a concorrência pelo trabalho. Segundo Howard Zinn, depois do crash

a produção industrial caiu em 50\%, e em 1933 talvez 15 milhões (ninguém sabe ao certo) - um quarto ou um terço da força de trabalho - estavam sem emprego. A Ford Motor Company, que na primavera de 1929 havia empregado 128.000 trabalhadores, tinha apenas 37.000 em agosto de 1931. No final de 1930, quase

\footnotetext{
${ }^{60}$ Little Caesar files. History of Cinema, Series 1, Hollywood and Production Code Administration. Herrick Library. Archives Unbound, p. 71-75. Disponível em http://proxy.library.upenn.edu:3437/gdsc/i.do? \&id=GALE\%7CSC5106190494\&v=2.1\&u=upenn_main\&it=r\&p=GDSC\&sw=w\&viewtype=fullcitation. Acessado em 11/01/2015.
} 
metade dos 280.000 trabalhadores da indústria têxtil da Nova Inglaterra estavam desempregados. ${ }^{61}$

As estatísticas de desemprego nesse período, afirma o historiador Sean Dennis Cashman, pareciam números de mortos em uma guerra mundial:

\footnotetext{
"Três anos depois do crash, uma média de 100.000 trabalhadores estavam sendo demitidos toda semana". Trabalhadores não-especializados, particularmente negros, formavam a tropa de choque, seguidos por trabalhadores administrativos e técnicos. (...) o produto interno bruto caiu de \$81 bilhões em 1929 para \$68 bilhões em 1930, \$53 bilhões em 1931, e \$41 bilhões em 1932, o menor nível atingido. Em outras palavras, durante os primeiros três anos da Depressão, oitenta e cinco mil empresas faliram, cinco mil bancos fecharam, e nove milhões de poupanças desapareceram. ${ }^{62}$
}

De certa maneira, o assassinato de Tony em Little Caesar cumpre a função de levar para a tela do cinema a disputa pelo emprego. Os gângsteres se matam não só por convenção do gênero, mas também pela concorrência por trabalho em tempos de crise. Ambos os elementos andam juntos dentro da narrativa. Se Tony delatar o grupo, estarão todos na gangue desempregados, sem fonte de renda em plena Depressão, e, no caso do protagonista, condenado à forca, como ele próprio repete algumas vezes no filme. Matar Tony é questão de sobrevivência para Rico.

Segundo o historiador Richard Pells, o que mais chamou a atenção no período pósCrise de 1929 foi a demora da sociedade norte-americana como um todo em reavaliar sua confiança na prosperidade oriunda dos anos 1920. O mercado financeiro já havia se comportado de maneira instável por vários meses, e desde o início de 1929 havia sinais de um perigoso avanço da inflação. Todavia, somente em outubro de 1930, um ano após a quebra em Wall Street, é que a percepção dos norte-americanos mudou em relação à economia. Antes disso, o discurso de que a turbulência no mercado financeiro era apenas um "reajuste temporário" na economia soava perfeitamente plausível ao cidadão comum. Dessa forma, já em novembro de 1929 o Crash não ocupava mais as primeiras páginas dos jornais, e tanto a produção industrial quanto o setor de vendas mantiveram uma certa estabilidade. O Natal de 1929 foi surpreendentemente próspero para os lojistas - um indício

\footnotetext{
${ }^{61}$ Zinn, H. A People's History of the United States. New York: HarperCollins Publishers, 2005, p. 387.

${ }^{62}$ Cashman, S. D. apud Balio, T. Surviving the Great Depression. In: Grand Design: Hollywood as a modern business enterprise, vol. 5, 1930-1939. New York: Simon \& Schuster Macmillian, 1993, p. 13.
} 
de que, ao menos aparentemente, a prosperidade econômica teria continuidade ao longo da década de $1930 .^{63}$

Tal aparência de prosperidade contaminou o ambiente político. A própria eleição do presidente Herbert Hoover pode ser tomada como um exemplo. Hoover havia sido eleito em 1928 com o objetivo de dar continuidade à administração republicana de Calvin Coolidge. O grande erro de Hoover, segundo Thomas Doherty, foi confiar na prosperidade do governo Coolidge e não perceber a crise que estava prestes a eclodir, além de demonstrar uma preocupante paralisia no período pós-Crise. Tal comportamento fez seu sobrenome virar sinônimo de fracasso. Os jornais viraram "Hoover blankets", os bolsos vazios para fora da calça viraram "Hoover flags" e acampamentos de desabrigados eram conhecidos como "Hoovervilles". ${ }^{4}$

A paralisia do governo Hoover no primeiro ano após o crash de 1929 pode ser estendida à comunidade intelectual de esquerda da época. Pells argumenta que nem a imprensa liberal, nem a radical - representadas respectivamente pelos jornais New Republic e New Masses - atentaram seus leitores para o perigo da Depressão. Mesmo no inverno de 1930, com as estatísticas de desemprego em crescimento, houve uma reação desses jornais. Ao mesmo tempo em que admitia uma "depressão industrial genuína" nos Estados Unidos, o New Republic apostava em um reaquecimento da economia no verão seguinte - o que nunca ocorreu. ${ }^{65}$

Por outro lado, o New Masses, que tinha uma postura bem mais radical do que o New Republic e era conhecido pelos seus leitores por prever anualmente o colapso do capitalismo, não demonstrou qualquer reação quando a crise ocorria de fato. Enquanto isso, os membros do Partido Comunista norte-americano, naquele momento imediatamente após o Crash, estavam mais preocupados em questões doutrinárias e disputas entre suas facções internas do que em atentar para as consequências da Crise. Na avaliação de Pells,

tanto o New Masses como os radicais de esquerda praticamente ignoraram o Crash e deram pouca atenção para a subsequente depressão até o fim de 1930. Em boa

\footnotetext{
${ }^{63}$ Cf. Pells, R. H. Radical Visions and American dreams: culture and social thought in the Depression years. New York: Harper\&Row, 1973, p. 43.

${ }^{64} \mathrm{Cf}$. Doherty, T. Pre-code Hollywood: sex, immorality, and insurrection in American cinema, 1930-1934.

New York: Columbia University Press, 1999, p. 25

${ }^{65}$ Cf. Pells, R. H., op. cit., p. 45.
} 
parte desse período, os Marxistas Americanos mostraram um talento notável para desconsiderar o país em que viviam. ${ }^{66}$

No âmbito cultural, além do próprio estabelecimento do Código, houve duas grandes mudanças tecnológicas significativas: a implementação das transmissões de rádio comercial e a sincronização de som e imagem no cinema. Tal progresso nos meios de produção cinematográficos resultou no aumento nos custos da aparelhagem (câmeras, estúdios sonoros, cabines de gravação e sistemas sonoros para as salas de cinema). Dessa maneira, esse período histórico também coincidiu com o avançado processo de industrialização do cinema, que excluiu pequenos empresários e estúdios do mercado cinematográfico. $\mathrm{O}$ cinema se tornou um negócio que envolvia tecnologia avançada e circulação de grandes volumes de capital. A verticalização dos processos de produção, distribuição e exibição solidificou-se, por volta de 1920, no oligopólio dos estúdios hollywoodianos - Columbia, Fox, MGM, Paramount, RKO, Universal e Warner Brothers.

O advento do som no cinema também teve como consequência uma mudança estética, com os diálogos, efeitos sonoros e a música integrados aos filmes. A quebra da bolsa de Nova Iorque em outubro de 1929 ocorreu no momento em que a indústria cinematográfica mais precisava de dinheiro para bancar os custos da introdução do som nos filmes. Dessa forma, o cenário da indústria cinematográfica norte-americana em meio à Depressão e à introdução do som era, simultaneamente, de vulnerabilidade financeira e instabilidade estética. Dentro desse panorama, Little Caesar consegue, por meio de uma narrativa de gângster, apresentar diversos temas bastante pertinentes para o contexto norte-americano da época.

Como pudemos observar, o relato dos historiadores nos mostra que a década de 1930 foi uma catástrofe econômica sem precedentes na história norte-americana. Foi durante a Depressão que os mitos da mobilidade social, do progresso material, do excepcionalismo americano, e do individualismo encolheram-se diante da devastação que a crise econômica provocou no país. Segundo o historiador Gerald Messadié,

em The Great Crash [O Grande Crash], um economista de renome internacional, John Kenneth Galbraith, recenseou com clareza as cinco causas fundamentais da Grande Crise. A primeira causa seria uma distribuição desigual da riqueza

\footnotetext{
${ }^{66}$ Pells, R. H. Radical Visions and American dreams: culture and social thought in the Depression years. New York: Harper\&Row, 1973, p. 44.
} 
nacional, que limitava o mercado dos bens de consumo e restringia tanto os investimentos quanto o comércio de luxo aos happy few, que os submetiam a caprichos erráticos. Assim, uma variação negativa do índice Dow Jones provoca perigosos abalos nos investimentos e no comércio de luxo. Em segundo lugar, havia as práticas fraudulentas de negócios, que aconteciam com enorme frequência e constituíam o que Galbraith chama de corporate larceny, ou seja, roubo efetuado pelas corporações. Em terceiro lugar, a estrutura bancária era fragmentada demais, e, portanto, propícia a comportamentos demasiado otimistas ou até mesmo fraudulentos dos banqueiros; seu principal inconveniente era que, em função dos créditos interbancários, a quebra de um banco ameaçava o equilíbrio de todos os outros, como uma carta que cai e faz desabar todo o castelo. Em quarto lugar, havia a nova posição dos Estados Unidos como grandes credores, que haviam concedido empréstimos imprudentes ao exterior. Isso que resultou, para os países devedores, na impossibilidade total de pagar sequer o serviço de suas dívidas, quanto mais o principal, sem falar dos juros, e de abrir seus mercados ou deixá-los abertos para as importações provenientes da América. Em quinto lugar, uma pobreza intelectual generalizada entre os economistas. Galbraith desconfia até de uma certa perversidade nos conselhos dos especialistas da época, uma vez que todo parecer econômico nos anos seguintes ao Crash de 1929 só levaram à piora da situação. ${ }^{67}$

É possível encontrar homologias estruturais presentes em Little Caesar em quase todas as causas da Grande Crise descritas acima. Corporate larceny e fraudes bancárias, por exemplo, podem ser consideradas, em um sentido amplo, crime organizado tanto quanto as operações da gangue de Rico.

O funcionamento do crédito interbancário, por sua vez, obedece a uma estrutura que é homóloga às redes de dívidas de honra que mantém o equilíbrio entre as forças envolvidas dentro do crime organizado, e que são, por sua vez, incorporadas de modo a estruturar as relações entre os personagens no filme. Em Little Caesar, a dívida de honra é enunciada por Joe quando o personagem explica a Olga que "uma vez dentro da gangue, não há retorno". Rico também cobra essa dívida ao deixar claro que, sem ter sido apresentado à gangue, Joe não teria conquistado nada na cidade grande.

A interdependência entre os bancos também é homóloga estruturalmente em Little Caesar aos acordos entre o crime organizado e a lei. No momento em que Vettori integra

\footnotetext{
${ }^{67}$ Messadié, G. A crise do mito americano - Réquiem para o super-homem. São Paulo: Ática, 1989, p. 254. Grifo nosso.
} 
Rico ao seu grupo, já havia sido instaurada a paz entre a polícia e as gangues do setor norte da cidade, divididas entre Arnie Lorch e Sam Vettori. Pete Montana, que está acima de Lorch e Vettori na hierarquia do crime organizado da cidade, também quer garantir que nenhum problema aconteça e convoca uma reunião para avisar que um novo comissário, Alvin McClure (Landers Stevens), assumiu o comando da polícia na cidade - caso algum problema aconteça, nem mesmo o Big Boy poderia intervir. A manutenção do status quo interessa a todos, menos a Rico, pois a paz entre as gangues e a polícia não combina com a busca pelos seus objetivos.

Podemos dizer que, sob o ponto de vista dos outros criminosos, Rico é um agente do caos, determinado a acabar com o equilíbrio preexistente - tal procedimento, de acordo com a crítica Fran Mason, estabeleceu um paradigma entre os filmes do gênero: o protagonista ultrapassa os limites do bem coletivo da gangue para buscar seus objetivos individuais. ${ }^{68}$ No caso de Rico, sua primeira providência é assassinar o comissário McClure durante o roubo ao Bronze Peacock e, com isso, "como uma carta que cai e faz desabar todo o castelo", desencadear uma série de eventos que culminariam na sua ascensão à liderança da gangue. Dessa maneira, a ação impulsiva de Rico põe em risco tanto o tênue equilíbrio interno entre gangues, quanto a frágil harmonia externa com a polícia. Em Little Caesar, no crime organizado e no capitalismo - especialmente em um momento de crise -, todas as relações são instáveis.

A agressividade comercial configurada no "comportamento fraudulento" de uma organização em relação a outra, especialmente em um período de recessão no mundo dos negócios, em que o grande capital sobrevive se alimentando e destruindo o pequeno capital, é registrada no filme por meio da violência que permeia a relação entre as gangues. A crise econômica é o momento em que a tendência genética monopolista do capital se acirra, e é possível observar esse comportamento na própria indústria cinematográfica durante a Depressão. Segundo o historiador Tino Balio,

na indústria cinematográfica, falências e concordatas ocorreram nas subsidiárias de exibição das grandes empresas, e não nos setores de produção e distribuição, o que resultou em batalhas ferozes pelo controle das salas de cinema do país no fim da década de 1920. Durante 1929, "eram raras as semanas em que uma ou duas das grandes empresas não estavam se fundindo ou absorvendo umas às outras",

${ }^{68}$ Cf. Mason, F. American Gangster Cinema - from Little Caesar to Pulp Fiction. New York: Palgrave Macmillian, 2002, p. 11. 
segundo a Variety. Paramount, Warners, e RKO eram particularmente agressivas e construíram ou adquiriram centenas de salas de exibição, o que resultou em milhões de dólares em dívidas. Quando o boom acabou em 1931, os cinemas luxuosos construídos numa época gloriosa a custos imprudentemente extravagantes, tornaram-se elefantes brancos, ao menos durante a Depressão. Em resumo, as grandes empresas não conseguiram honrar seus compromissos financeiros, o que significava que elas não tinham dinheiro para pagar suas hipotecas, seus compromissos de curto prazo, e os pesados encargos sobre suas dívidas. ${ }^{69}$

Essa mesma agressividade do capital em momentos de crise é registrada no filme - não de forma direta ou denotativa, mas de forma conotativa - por meio da violência entre as gangues e da instabilidade das posições dos seus chefes, como Vettori, Little Arnie e Pete Montana. A queda paulatina de cada um deles, além do apetite monopolista e expansionista do pequeno César, figura a crise nos termos do gangsterismo. Por meio da representação das relações entre gangues, o filme mostra o funcionamento do capital monopolista em épocas de crise e registra a movimentação do capital como atividade criminosa.

\section{A administração do tempo}

Logo após a cena inicial no posto de gasolina, vemos outro plano geral bem rápido, dessa vez de um pequeno restaurante à beira de uma estrada, com o carro da cena anterior parado à frente. Em seguida, a câmera mostra um close da mão de Rico atrasando o relógio do restaurante a fim de criar um álibi em sua defesa caso seja acusado pelo crime que vimos na cena anterior (Figura 6). O gesto de atrasar o relógio é emblemático para a narrativa de Little Caesar porque representa uma tentativa de Rico de controlar o tempo que, para o gângster, é sempre curto, pois ele sabe que a qualquer momento pode ser preso ou morto. Suas ações são cuidadosamente planejadas, com dia, hora e local combinados, e devem ser executadas da maneira mais rápida e eficiente possível.

${ }^{69}$ Balio, T. Grand Design: Hollywood as a modern business enterprise, vol. 5, 1930-1939. New York: Simon \& Schuster Macmillian, 1993, p. 16. 


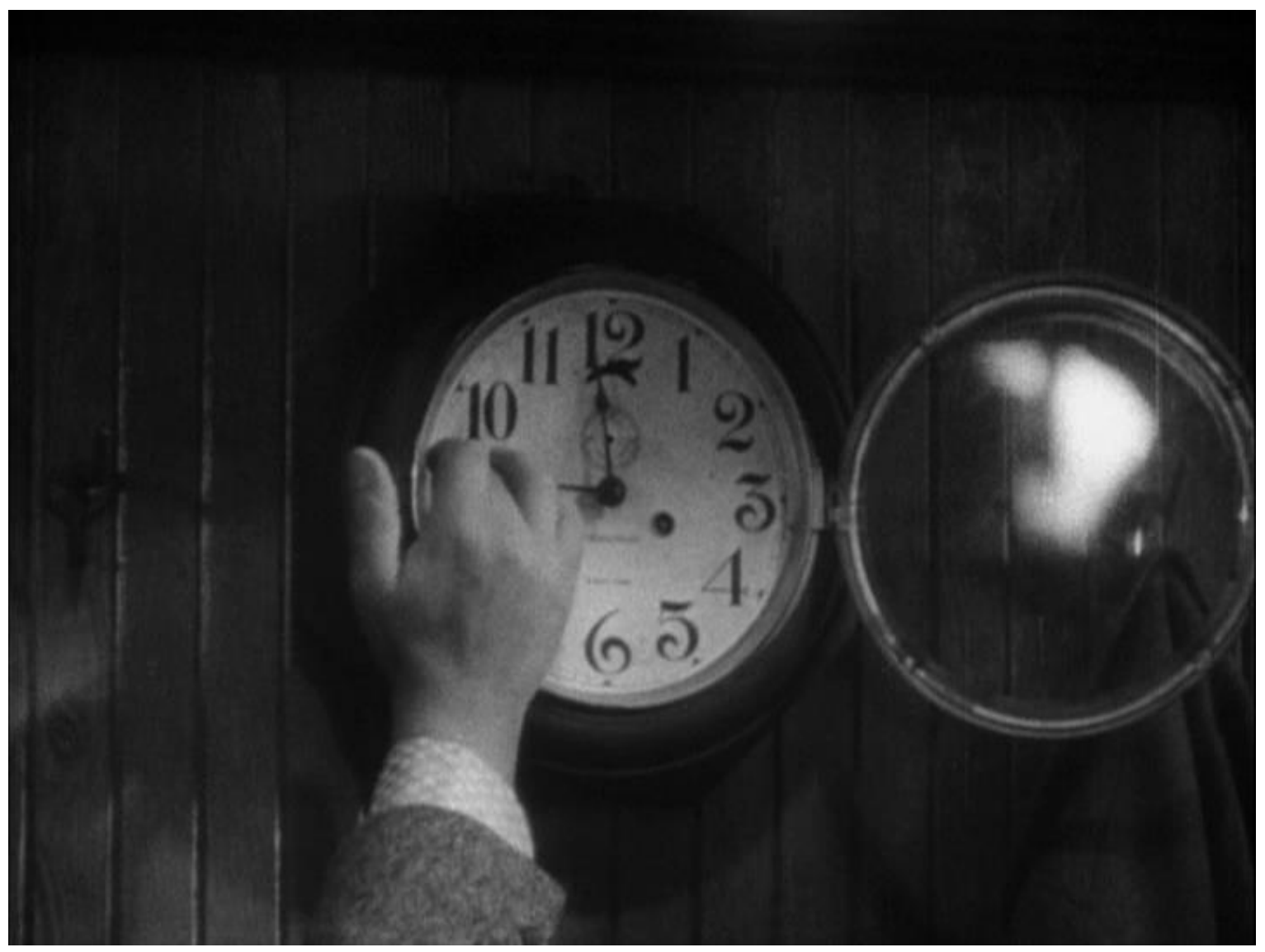

Figura 6 - O gângster atrasa o relógio do restaurante.

De acordo com o historiador Richard Pells, Rico não luta por poder ou propriedades,

mas pela imortalidade. Quando o público o vê pela primeira vez ele está atrasando os ponteiros de um relógio, em parte para criar um álibi, mas também para representar seu medo do tempo. ${ }^{70}$

Assim, na medida em que luta pela imortalidade, o gângster teme pela sua vida, pois o ritmo frenético de seu cotidiano e os riscos que ele corre em nome dos seus objetivos são resultados de sua tentativa de "viver a vida em sua plenitude". Desse modo, "relógios têm uma presença constante ao longo do filme, marcando o fluxo e o declínio da vida de Rico, zombando do seu desejo de ser alguém, chamando-o cedo para a morte"71.

A análise que Pells realiza sobre a cena no restaurante deixa de lado um aspecto de ordem materialista sobre as condições de produção de Little Caesar: a introdução do tema do tempo no filme o coloca em sintonia com as discussões críticas mais avançadas sobre a

\footnotetext{
${ }^{70}$ Pells, R. H., Radical Visions and American dreams: culture and social thought in the Depression years. New York: Harper\&Row, 1973, p. 272.

${ }^{71}$ Idem.
} 
relação entre tempo e trabalho, uma vez que a

civilização industrial/capitalista é dominada, de maneira crescente desde o século XIX, pelo tempo do relógio de bolso ou de pulso, passível de uma medida exata e estritamente quantitativa. As páginas de $O$ Capital são cheias de exemplos terríveis da tirania do relógio sobre a vida dos trabalhadores. Nas sociedades précapitalistas, o tempo era carregado de significados qualitativos, que foram progressivamente substituídos, durante o processo de industrialização, pelo tempo único do relógio de pulso. ${ }^{72}$

Foi no período de forte industrialização pelo qual os Estados Unidos passaram no fim do século XIX e início do século XX que o taylorismo e, posteriormente, o fordismo popularizaram o conceito de "gerenciamento científico" do trabalho.

O economista Harry Braverman nos esclarece que, sendo o trabalho uma "propriedade inalienável” do corpo humano, "o que o trabalhador vende e o que o capitalista compra não é uma determinada quantidade de trabalho, mas a capacidade de trabalhar por uma determinada quantidade de tempo"73. Dessa forma, a única ferramenta de que o capitalista dispõe para dominar o processo produtivo - que depende do trabalho humano - é o controle do tempo que o trabalhador gasta para realizar suas tarefas. Foi com esse princípio em mente que o engenheiro mecânico norte-americano Frederick Winslow Taylor publicou, em 1911, seu livro The Principles of Scientific Management.

Taylor popularizou o estudo do tempo como parte de sua tentativa de ganhar controle sobre o trabalho. $\mathrm{O}$ estudo do tempo pode ser definido como a medida do tempo decorrido para cada operação de um processo de trabalho; seu principal instrumento é o cronômetro, calibrado em frações de hora, minuto ou segundo. (...) [Frank B. Gilberth, um dos seguidores de Taylor] adicionou ao estudo do tempo o conceito de estudo do movimento; ou seja, a investigação e classificação dos movimentos básicos do corpo, independentemente da forma particular ou concreta de trabalho em que esses movimentos são utilizados. No estudo do movimento e do tempo, os movimentos essenciais eram visualizados como fundamentos de qualquer atividade de trabalho. ${ }^{74}$

\footnotetext{
${ }^{72}$ Löwy, M. Walter Benjamin: aviso de incêndio - uma leitura das teses "Sobre o conceito de história". São Paulo: Boitempo Editorial, 2007, p. 125.

${ }^{73}$ Braverman, H. Labor and monopoly capital: the degradation of work in the twentieth century. New York: Monthly Review Press, 1998, p. 39.

${ }^{74}$ Ibidem, p. 119-120.
} 
O estudo de Taylor demonstrou que, da maneira como se configurava o trabalho, as fábricas não eram geridas pelos donos, mas sim pelos operários, que determinavam a velocidade e o modo com que cada trabalho seria feito. Essa era a origem dos problemas de produtividade enfrentados pelos empresários. Taylor propôs, então, o modelo de "gerenciamento científico" do trabalho, no qual haveria uma cisão entre sua concepção e execução. Tal separação entre trabalho mental e braçal teve como consequência uma "desumanização do processo de trabalho, no qual trabalhadores são reduzidos ao nível de trabalho na sua forma mais primitiva". O trabalho em si tornou-se parte do capital e, portanto, propriedade do capitalista, ou seja, tornou-se trabalho alienado. Os trabalhadores perderam controle não só dos seus meios de produção, mas também do seu próprio trabalho e de como realizá-lo. "Esse controle agora está sob o comando de quem pode 'pagar' pelo estudo [do trabalho], a fim de conhecê-lo melhor do que os próprios trabalhadores conhecem sua atividade de vida". ${ }^{75}$

O passo seguinte no controle do capitalista sobre o processo de produção industrial foi dado por Henry Ford e sua linha de produção em série, com a "colocação do objeto de trabalho num mecanismo automático que percorresse todas as fases produtivas" ${ }^{\text {"76. Tal }}$ sistema teve resultados impressionantes: a fábrica de Henry Ford produzia um Modelo T a cada 15 segundos, e foi capaz de fabricar mais carros em 3 meses do que toda a Europa em um ano. ${ }^{77}$ Com o sistema fordista,

\begin{abstract}
buscou-se estrangular ao máximo os poros da jornada de trabalho, de modo que todas as ações realizadas pelos trabalhadores estivessem, a cada instante, agregando valor aos produtos. Se a "racionalização" taylorista permitia uma significativa intensificação do trabalho humano através do controle pela cronometragem dos tempos de operação parciais, no sistema fordista é a velocidade automática da linha de série (do objeto de trabalho, portanto) que impõe ao trabalhador (o sujeito do trabalho) a sua condição de disposição para o labor, estabelecendo, dentro de limites cada vez mais estreitos de tempo, a "melhor maneira de trabalhar". ${ }^{78}$
\end{abstract}

Se o taylorismo provocou a cisão entre a concepção e execução do trabalho, o fordismo adicionou a essa equação a submissão ao ritmo ditado pela máquina e instaurou a

\footnotetext{
${ }^{75}$ Braverman, H. Labor and monopoly capital: the degradation of work in the twentieth century. New York: Monthly Review Press, 1998, p. 78-80.

${ }^{76}$ Cf. Pinto, G. A. A organização do trabalho no século 20: taylorismo, fordismo, toyotismo. São Paulo: Expressão Popular, 2010, p. 35.

77 Ibidem, p. 37.

${ }^{78}$ Ibidem, p. 38.
} 
"tirania do relógio sobre a vida dos trabalhadores". Em última instância, o próprio ser humano torna-se mecanizado, pois

\begin{abstract}
o princípio que rege as investigações sobre o trabalho é a visão do ser humano em termos mecânicos. Como os administradores não estão interessados no trabalhador em si, mas em como ele é utilizado no escritório, fábrica, armazém, estoque, ou no processo de transporte, essa visão é, do ponto de vista da administração, não só eminentemente racional, mas a base de todo o cálculo. (...) A tentativa de conceber o trabalhador como uma máquina de propósito geral operada pela gerência é um dos diversos caminhos tomados com o mesmo objetivo: o deslocamento do trabalho como elemento subjetivo do processo de trabalho e sua transformação em um objeto. ${ }^{79}$
\end{abstract}

Dois aspectos sobre o processo de "aceleração do tempo" merecem ser destacados. Um deles é de ordem material: tal aceleração visa a melhora da produtividade da força de trabalho, ou a "melhor maneira de trabalhar", e, consequentemente, o aumento da taxa de extração de mais-valia absoluta pelo capitalista. O outro aspecto é imaterial, pois está ligado à aceleração de acumulação de capital fictício por meio do sistema de crédito, que, segundo Karl Marx,

\begin{abstract}
em seus primórdios insinua-se sorrateiramente como modelo de auxílio da acumulação e, por meio de fios invisíveis, conduz às mãos de capitalistas individuais e associados recursos monetários que se encontram dispersos na sociedade em massas maiores ou menores, mas logo se converte numa arma nova e temível na luta concorrencial e, por fim, num gigantesco mecanismo social para a centralização dos capitais. ${ }^{80}$
\end{abstract}

Tanto a aceleração material - o incremento da produtividade do trabalho causa a superprodução - quanto a imaterial - o aumento de capital fictício gera inchaço no sistema de crédito - desenvolveram-se de maneira coordenada e ambas contribuíram para o processo que culminou na quebra da bolsa de Nova Iorque em 1929. O Crash acelerou ainda mais a deterioração das condições de trabalho na década de 1930 e, por consequência, contribuiu

\footnotetext{
${ }^{79}$ Braverman, H. Labor and monopoly capital: the degradation of work in the twentieth century. New York: Monthly Review Press, 1998, p. 124.

${ }^{80}$ Marx, K. O capital: Crítica da economia política, Livro I: O processo de produção do capital. São Paulo: Boitempo Editorial, 2013, Capítulo 23, Seção 2. Grifo nosso.
} 
para o avanço do gangsterismo que vemos em Little Caesar como alternativa para a classe trabalhadora em meio à crise.

Uma análise mais atenta do gangsterismo nos mostra que ele próprio é um tipo de prática social cuja finalidade é a aceleração temporal - por meio do gangsterismo é possível galgar os degraus da escala social sem passar pelos meandros do trabalho alienado. Em The Great Gatsby, de F. Scott Fitzgerald, por exemplo, o protagonista recorre ao gangsterismo porque percebe que não pode passar pelo caminho interminável do trabalho legal se quiser acelerar o processo de retomada da conquista amorosa, que, na avaliação do próprio protagonista, depende de sua ascensão à upper class. Dessa maneira, a base do romance, assim como de Little Caesar, é a aceleração do enriquecimento por meios ilegais. Esse processo é o mesmo do enriquecimento por meio da oferta de crédito. Sendo assim, podemos dizer que a ascensão social tanto de Rico como de Jay Gatsby é rápida, acelerada, tal qual se dá o acesso ao crédito - a estrutura de funcionamento do capital financeiro torna-se também uma das estruturas do enredo do filme de gângster.

Na avaliação de Guy Debord, embora o tempo do trabalhador tenha se tornado propriedade da burguesia, o proletariado ainda carrega o potencial de reivindicar para si o "tempo histórico":

\begin{abstract}
A burguesia mostrou e impôs à sociedade um tempo histórico irreversível, mas lhe recusa o uso desse tempo. "Houve história, mas já não há", porque a classe dos possuidores da economia, que não pode romper com a história econômica, deve rechaçar como ameaça imediata qualquer outro emprego irreversível do tempo. A classe dominante, feita de especialistas da posse das coisas - que, por isso, são eles mesmos possuídos pelas coisas -, deve ligar seu destino à manutenção dessa história reificada, à permanência de uma nova imobilidade na história. Pela primeira vez o trabalhador, na base da sociedade, não é materialmente estranho à história, porque agora é por sua base que a sociedade se move irreversivelmente. $\mathrm{Na}$ reivindicação de viver o tempo histórico, o proletariado encontra o centro inesquecível de seu projeto revolucionário; e cada uma das tentativas, até aqui destruídas, de executar esse projeto marca um ponto de partida possível da nova vida histórica. ${ }^{81}$
\end{abstract}

Dentro da indústria cinematográfica, podemos considerar como "reivindicações de viver o tempo histórico" - em outras palavras, a insubordinação do trabalhador ao tempo

\footnotetext{
${ }^{81}$ Debord, G. A sociedade do espetáculo. Rio de Janeiro: Contraponto, 1997, p. 99-100.
} 
mecanizado -, o próprio trabalho do ator, que

\begin{abstract}
não representa diante de um público, mas de um aparelho. O diretor ocupa o lugar exato que o controlador ocupa num exame de habilitação profissional. Representar à luz dos refletores e ao mesmo tempo atender às exigências do microfone é uma prova extremamente rigorosa. Ser aprovado nela significa para o ator conservar sua dignidade humana diante do aparelho. $\mathrm{O}$ interesse desse desempenho é imenso. Porque é diante de um aparelho que a esmagadora maioria de citadinos precisa alienar-se de sua humanidade, nos balcões e nas fábricas, durante o dia de trabalho. À noite, as mesmas massas enchem os cinemas para assistirem à vingança que o intérprete executa em nome delas, na medida em que o ator não somente afirma diante do aparelho sua humanidade (ou o que aparece como tal aos olhos dos espectadores), como coloca esse aparelho a serviço de seu próprio triunfo. $^{82}$
\end{abstract}

A relação do trabalhador com o tempo e com as máquinas no cinema já havia se decantado como forma em diversas produções de Buster Keaton, como Sherlock Jr. (1924). O filme nos apresenta, por meio de gags milimetricamente organizadas e ações sincronizadas com exatidão, o domínio de Keaton sobre o aparato cinematográfico ao mesmo tempo em que "coloca esse aparelho a serviço de seu próprio triunfo", como na sequência em que Keaton anda sobre o guidão de uma motocicleta sem piloto e escapa por um triz de diversos tipos de acidentes. Alguns anos mais tarde, Charles Chaplin avançou diretamente no debate sobre a submissão do trabalhador ao tempo mecanizado quando registrou a linha de montagem fordista em Modern Times (1936), no qual o protagonista, em determinado momento, torna-se literalmente parte das engrenagens da fábrica onde trabalha.

${ }^{82}$ Benjamin, W. A obra de arte na era da reprodutibilidade técnica. In: Obras escolhidas, Magia e técnica, arte e política, v. I trad. S.P. Rouanet. São Paulo: Brasiliense, 1985, p. 179. 

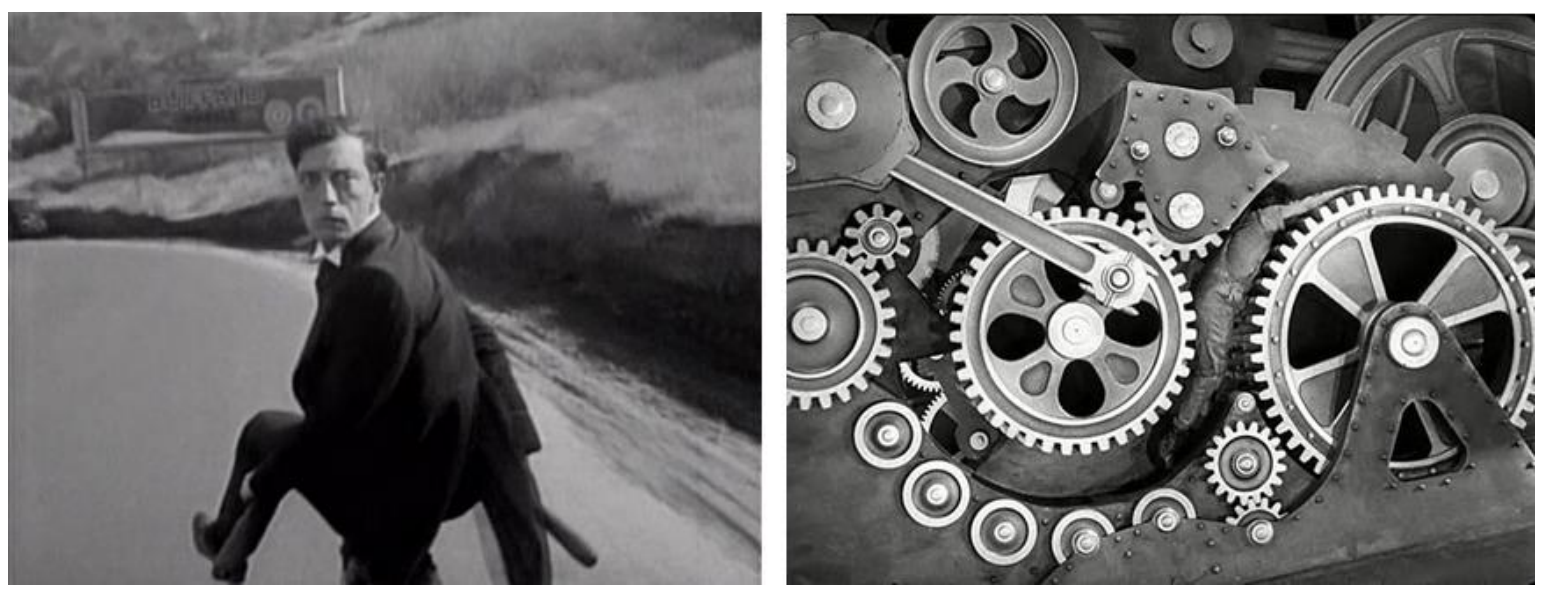

Figura 7 - Buster Keaton (esq.) e Charles Chaplin (dir.) (Sherlock Jr., 1924, e Tempos Modernos, 1934, respectivamente)

Levando-se em consideração todo o debate que havia em torno do desenvolvimento do taylorismo e do fordismo nos primeiros anos do século XX, além de exemplos prévios no cinema do tratamento desses temas, podemos dizer que a administração do tempo de trabalho faz parte do inconsciente político de Little Caesar. É possível chegar a um aproveitamento crítico sobre essa questão observando-se o ritmo do filme.

Há na narrativa um constante senso de urgência do protagonista, que o faz "correr contra o tempo" durante todo o filme: Rico exige precisão no horário do roubo ao Bronze Peacock, apressa-se na eliminação de Tony antes que ele fale com o padre McNeil, corre da polícia para não ser capturado. Entretanto, ao contrário do que pode parecer num primeiro momento, Rico está sim, de certa forma, submetido à temporalidade que caracteriza a vida da classe trabalhadora. Essa característica surge em Little Caesar de duas formas: na banalidade e repetição de determinadas ações - como o jogo de paciência que Sam Vettori usa para passar o tempo e as repetidas reuniões da gangue para planejar seus próximos atos - e na impossibilidade de Rico fazer o que bem entende no momento em que melhor lhe convir. O protagonista descobre, ainda no início do filme, que acima de Pete Montana sobre o qual ele havia lido no jornal na primeira cena do filme - há ainda mais um chefe (Big Boy) na hierarquia das gangues. Sendo assim, se quiser chegar ao topo, assim como em qualquer empresa, Rico precisa de tempo para trabalhar e conquistar seu espaço. A diferença, como já apontamos anteriormente, está na velocidade em que o gângster consegue acumular capital por meios ilegais e a possibilidade real de ascensão social que esse acúmulo the proporciona - dois privilégios que a classe trabalhadora não tem. 
O que mascara a submissão de Rico ao tempo no filme são dois clichês do filme de aventura. Em primeiro lugar, o ritmo é propositalmente acelerado para manter o espectador atento à narrativa. É possível observar esse procedimento no tempo que Rico leva para galgar os degraus da hierarquia das gangues depois de assumir a liderança do grupo de Vettori. Da cena do banquete em homenagem a Rico ao encontro com Big Boy passam-se somente vinte minutos, cerca de um quarto do filme. Em segundo lugar, há diversos momentos distribuídos na narrativa que criam um aumento de tensão no espectador: a cena de assassinato do comissário McClure, a discussão entre Vettori e Rico pela partilha do dinheiro do roubo ao Bronze Peacock, a aproximação de Tony à igreja para delatar Rico, entre outros.

Dessa maneira, é possível ler o filme sob duas perspectivas diferentes. Ao mesmo tempo em que há a mobilização do filme em torno da convenção do clichê aventuresco, existe uma demanda da matéria histórica que exige uma outra leitura: o mesmo ritmo que faz parte da convenção do filme de aventura, nesse momento histórico também fala sobre o ritmo do trabalho submetido a uma exigência temporal, um ritmo externo ao personagem, não o ritmo de sua subjetividade.

\section{O American Dream e a indústria cultural}

Depois de atrasar o relógio, Rico se senta ao lado de Joe no balcão do restaurante e pergunta ao parceiro o que achou da sua ideia. A câmera registra os dois personagens de frente em plano americano. Joe diz que admira a esperteza de Rico, cuja "mente está sempre funcionando". Joe faz o pedido ao garçom e, enquanto aguardam a comida, Rico pega um jornal no balcão e lê em voz alta uma manchete na primeira página, que é focalizada em close pela câmera: "Submundo homenageia 'Diamond' Pete Montana". Há um corte, e a câmera volta ao plano americano anterior. Joe pergunta a Rico qual a importância da notícia. Após um novo corte, a câmera mostra Rico em close enquanto diz prontamente para Joe:

Rico: Muita. "Diamond" Pete Montana. Ele não perde tempo com postos de gasolina. Ele é alguém. Ele está na cidade grande, fazendo coisas grandes. E olhe pra gente, dois pobres coitados, nada.

Joe: [em um plano mais aberto] É isso que você quer, Rico? Uma festa dessas para você? [Joe olha para cima, imaginando uma manchete de jornal] "Caesar Enrico Bandello, homenageado pelos seus amigos". 
Rico: [Em plano americano, mostrando ambos os personagens] Eu poderia fazer tudo o que esse sujeito faz, e muito mais. Só que eu nunca tive a minha chance. Não tenho medo de nada. Quando estou numa encrenca, saio dela aos tiros. Quando eu chegar lá, será do meu jeito. Atiro primeiro, pergunto depois. Esse jogo não é para gente fraca.

Joe, por sua vez, declara que só quer dinheiro para ter roupas caras, mulheres e depois abandonar a vida de bandido. Nesse momento, Rico é focalizado em close novamente, com a fala de Joe em voz-over:

Joe: Quero voltar a dançar, como eu costumava fazer antes de te encontrar. Não sei, não fui feito para esse tipo de coisa. Dançar. Isso é o que eu quero fazer.

Rico: [com olhar incrédulo] Dançar? Mulheres? E aonde isso tudo vai te levar? Não quero saber de dançar. Quero fazer os outros dançarem para mim.

Joe: Bom, eu não me esqueci do dinheiro.

Rico: Dinheiro é bom, mas não é tudo. Quero ser alguém na vida. [olhando para fora do enquadramento enquanto gesticula com uma faca na mão] Olhar bem fundo para um bando e saber que eles fariam o que eu quisesse. Do meu jeito ou nada. Ser alguém na vida.

Joe: [câmera em plano americano mostrando os dois personagens] Você chega lá, Rico. [batendo nas costas de Rico]

Rico: É... Quer saber? Essa foi a nossa última vez nessa espelunca. Nós vamos embora.

Joe: Para onde?

Rico: Para o leste. Onde as coisas acontecem. 


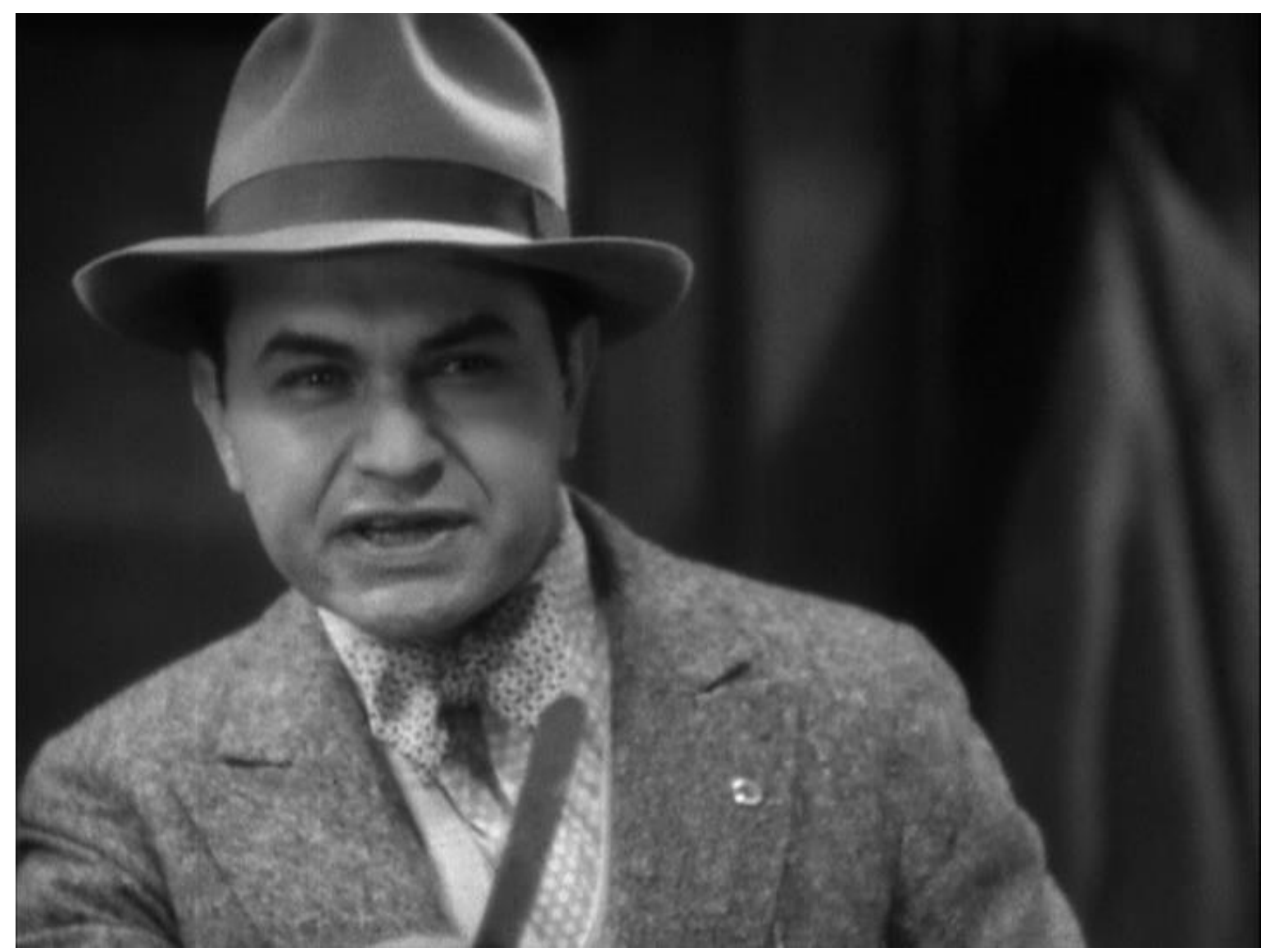

Figura 8 - Rico gesticula com uma faca na mão.

A sequência do diálogo entre Joe e Rico no restaurante apresenta ao espectador características importantes sobre os dois personagens que ajudam a compreender suas ações ao longo da narrativa. Fisicamente, Rico compensa sua baixa estatura com trejeitos enérgicos e ríspidos; o gângster é caracterizado como um sujeito carrancudo, e a tensão na sua expressão facial só é amenizada em poucos momentos do filme - quando o gângster sorri para a foto do jornal, ou quando se alegra ao receber de Big Boy a notícia de que ocupará o lugar de Pete Montana, por exemplo. Ele é extremamente preocupado com sua própria imagem: as roupas de tecido barato dessa cena de apresentação evoluem de acordo com a ascensão de Rico na hierarquia da gangue; além disso, o protagonista está constantemente penteando o cabelo e adquirindo adornos para a sua aparência, principalmente joias, imitando os acessórios utilizados pelos seus superiores. Rico é prático, inteligente e rápido nas palavras. Apesar de ser o protagonista, ele não é construído de maneira a provocar no espectador uma adesão emocional, ao menos não da forma tradicional dramática, pois, além 
de fazer de tudo para impedir o romance entre Joe e Olga, o gângster é antipático, grosseiro, e impõe respeito aos outros personagens por meio do medo.

Joe, por sua vez, personifica um contraponto visual ao protagonista: o amigo de Rico é um dançarino alto e esbelto, cuja fala e trejeitos são bem mais suaves e comedidos que seu parceiro. Mesmo tendo participado de um latrocínio na cena anterior, Joe ganha a simpatia do espectador na primeira vez em que surge na tela por demonstrar o desejo de abandonar a vida de crimes. O diálogo inicial entre os dois personagens mostra ao espectador que, quando se trata dos objetivos a serem alcançados, Joe também quer dinheiro, mas para comprar roupas, conquistar mulheres e, em seguida, abandonar a vida de criminoso - a ordem em que Joe enumera seus desejos mostra que, a princípio, ele não se importa com a ilegalidade de suas ações para, posteriormente, atingir um objetivo "nobre".

Um dos pontos que mais chamam nossa atenção na apresentação dos dois personagens é a caracterização de Rico como um personagem que concentra em si a noção de empreendedorismo no mundo dos negócios ilegais. O objetivo do protagonista é "ser alguém na vida", e o personagem dá a entender que fará tudo o que for necessário para isso. Dessa forma, "apesar de todo o tiroteio, violência deliberada e onipresença da morte, o filme de gângster do início dos anos 1930 servia primordialmente como uma história de sucesso" $"$.

Vale ressaltar que tanto o modus operandi do gângster no cinema como o fato da narrativa tê-lo como protagonista reforça, por meio da indústria cultural, o mito do sucesso individual na sociedade norte-americana. Sobre esse aspecto, Messadié aponta o ensaísta norte-americano Ralph Waldo Emerson como grande arauto. Segundo Messadié, Emerson

reforçou de modo singular a aspiração americana à liberdade total de ação: para o americano de então, assim como para os seus descendentes de hoje, o homem está só diante de Deus e, no fundo, só tem a obrigação de prestar contas a Ele. Pode-se imaginar o que um semelhante postulado implicou em termos de violência nas relações sociais e o quanto essa negação do contrato social resultou numa associabilidade que chega a beirar a anarquia. ${ }^{84}$

\footnotetext{
${ }^{83}$ Bergman, A. We're in the Money: Depression America and its films. Chicago: Ivan R. Dee, 1992, p. 6. ${ }^{84}$ Messadié, G. A crise do mito americano - Réquiem para o super-homem. São Paulo: Ática, 1989, p. 3233.
} 
O sucesso individual e a mobilidade social, mesmo no período pós-crise de 1929, estavam no âmago do que os norte-americanos consideram como o American Dream - um dos temas mais recorrentes no cinema norte-americano e, segundo Messadié, fonte do sentimento de superioridade dos EUA perante outras nações:

O American Dream designa não tanto um projeto nacional quanto uma massa de aspirações individuais à auto-realização, como é comum a todos os seres humanos, porém uma realização com a marca do evangelismo (...) e do milenarismo que acompanha qualquer evangelismo. O sonho americano esteve presente desde o estabelecimento dos primeiros colonos: cada um viveria numa liberdade bíblica e se entregaria afinal, sem entraves - o que subentendia os entraves da sociedade decadente, papista e corrompida do Velho Continente -, aos seus afazeres terrenos. Assim, contribuiriam para a edificação de uma grande nação, cujo exemplo conquistaria todas as demais. Pode-se comparar esse evento à instalação dos judeus na Terra Prometida. (...) O Sonho Americano, assim, tinha também a marca de um sentido de predestinação que marcou fortemente a política americana a partir da Guerra da Independência, e lhe deu essa coloração arrogante que tanto surpreende os estrangeiros. É dele que decorre o sentimento inato de todo americano de que tudo o que é americano é superior, simplesmente porque é americano, e, assim como o que é bom para a General Motors é bom para a América, o que é bom para a América é necessariamente bom para o resto do mundo. ${ }^{85}$

O historiador Jim Cullen divide a formação do American Dream em seis etapas. A primeira delas diz respeito aos imigrantes puritanos ingleses que, fugidos da perseguição religiosa que sofriam na Europa, atravessaram o Oceano Atlântico no século XVII em busca de uma "terra prometida" e colonizaram os EUA em nome da fé. A segunda etapa está ligada à Declaração de Independência dos EUA que, em 1776, institucionalizou como direitos inalienáveis dos cidadãos americanos "a Vida, a Liberdade e a busca da Felicidade". Segundo Cullen, "a busca da felicidade" define, melhor do que qualquer outra frase, "o American Dream ao tratar a felicidade como algo concreto e como um objetivo realizável"86.

A terceira etapa do American Dream está relacionada à crença na mobilidade social, ou seja, por meio do trabalho árduo qualquer um pode sair da pobreza e tornar-se "alguém na vida", como deseja Rico. Uma quarta etapa se desenvolve em torno do "sonho da

\footnotetext{
${ }^{85}$ Messadié, G. A crise do mito americano - Réquiem para o super-homem. São Paulo: Ática, 1989, p. 120. ${ }^{86} \mathrm{Cf}$. Cullen, J. The American Dream: A short history of an idea that shaped a nation. New York: Oxford University Press, 2003, p. 38.
} 
igualdade", que pode se desdobrar em diversos tipos: igualdade política, igualdade civil, igualdade social e igualdade racial. ${ }^{87}$ A quinta etapa diz respeito ao "sonho da casa própria", que se institucionalizou em 1862 no Homestead Act assinado por Abraham Lincoln e culminou no desenvolvimento dos centros urbanos, dos subúrbios e no aumento da dependência do transporte por carros ao longo do século XX. Finalmente, a última etapa de formação do American Dream é definida por Cullen como o "sonho do litoral" (Dream of the Coast), e é geograficamente centralizada na Califórnia, uma região do território dos EUA considerado, no imaginário do cidadão norte-americano, um lugar que une o clima agradável à possibilidade de enriquecer repentinamente e sem tanto esforço - seja na Corrida do Ouro no século XIX, nos cassinos de Las Vegas no século XX, ou em Hollywood, com a fama e fortuna de suas estrelas com carreiras meteóricas. ${ }^{88}$

De todas as etapas descritas por Cullen, aquelas que estão mais diretamente relacionadas ao desejo de Rico de "ser alguém na vida" são o sonho da "mobilidade social" e da "busca pela felicidade". Entretanto, o que o filme nos apresenta - e o que constitui um de seus grandes potenciais críticos - é uma versão corrompida do American Dream, que não cabe no conceito mais incauto do sonho americano, mas que faz todo sentido dentro das condições de produção do filme. Little Caesar conta uma história, já na época de sua produção, "muito antiga na América. Rico pertence a uma nação que exige dele o sucesso individual e, em 1930, não oferecia as oportunidades de conquistá-lo legalmente"89.

O grande veículo responsável pela ideologia do American Dream em Little Caesar é, como apontamos anteriormente, a indústria cultural, que se configura no filme de duas formas: nos espetáculos de dança e nas notícias de jornal mostradas ao longo da narrativa. A dança aparece no discurso de Joe tanto como um desejo de retorno a uma atividade que ele praticava antes de encontrar Rico, como uma alternativa ao crime simultaneamente legal e viável economicamente.

A escolha de Joe não é feita por acaso, pois a dança era uma forma de entretenimento muito popular no início do século XX, não só nos musicais da Broadway ou em salões de clubes com apresentações de jazz ao vivo, mas também na forma mais perversa das "maratonas de dança", que surgiram como forma de espetáculo ao longo da década de 1920 e ganharam força durante a Depressão. De acordo com a historiadora Carol J. Martin, essas

\footnotetext{
${ }^{87} \mathrm{Cf}$. Cullen, J. The American Dream: A short history of an idea that shaped a nation. New York: Oxford University Press, 2003, p. 105.

${ }^{88}$ Ibidem, p. 133-184.

${ }^{89}$ Bergman, A. We're in the Money: Depression America and its films. Chicago: Ivan R. Dee, 1992, p. 9.
} 
maratonas podiam se estender por até doze semanas, mas os prêmios em torno de US\$ 1,500.00 atraíam centenas de competidores da classe trabalhadora, muitas vezes desempregados que viam nessas competições um modo de sobrevivência. Segundo Martin, as maratonas de dança

parecem resumir o American Dream em uma de suas manifestações mais insanas e contraditórias. As maratonas mostravam coragem e esperança, determinação e estupidez, nonsense e decorações patrióticas, capacidade atlética e uma mistura incomum de números musicais, diversão honesta e piadas vulgares, meninos e meninas "de bem" e prostituição, resistência incansável e total esgotamento. ${ }^{90}$

A dança também está relacionada ao próprio desenvolvimento técnico do cinema nesse período. A transição do cinema sonoro para o mudo provocou um aumento nos custos de produção e execução dos filmes, e elevou substancialmente os investimentos feitos por Wall Street em Hollywood ${ }^{91}$. Dessa maneira, os estúdios se viram obrigados a explorar de maneira explícita a nova técnica a fim de justificar o dinheiro investido, e o musical passou a ser o principal gênero utilizado pela indústria como vitrine do avanço tecnológico. A maior prova disso foi a escolha desse gênero para a estreia da técnica com The Jazz Singer (Gordon Hollingshead, Alan Crosland, 1927).

Assim sendo, a análise da matéria histórica nos leva a acreditar que a escolha de Joe pela dança como alternativa para a vida criminosa visa a sua inserção numa indústria do espetáculo em pleno desenvolvimento. Se levarmos em conta que "Joe" é o nome inglês para o homem comum ${ }^{92}$, também podemos dizer que a dança ocupa o espaço do desejo do personagem - a inserção no mundo do espetáculo é o sonho do Zé Ninguém.

Além da dança, o jornal também é um elemento da indústria cultural que tem relevância para o enredo de Little Caesar. É por causa da manchete da homenagem a Pete Montana que Rico resolve tentar a vida em Chicago; quando Rico chega à liderança da gangue, sua fotografia é publicada na capa do jornal, do qual o gângster compra dez unidades para guardar de recordação; a expulsão de Arnie Lorch, um dos inimigos de Rico, da cidade

\footnotetext{
${ }^{90}$ Martin, C. J. Dance Marathons: Performing American Culture of the 1920s and 1930s. Jackson: Univ. Press of Mississippi, 1994, p. xv.

91 O grupo de investimentos Goldman, Sachs \& Company financiou a compra dos estúdios Vitagraph e First National, além da rede de salas de cinema Stanley Theatres, pela Warner Bros.; o cabeamento do sistema sonoro das salas de cinema de todo o país e a construção de estúdios de som em Hollywood foi financiada em grande parte pelos grupos bancários Morgan e Rockefeller. (Cf. Balio, T. Grand Design: Hollywood as a modern business enterprise, vol. 5, 1930-1939. New York: Simon \& Schuster Macmillian, 1993, p. 21-23.) 92 Common Joe e Average Joe são expressões em inglês usadas para denominar o sujeito americano medíocre.
} 
é consumada com uma nota na coluna social; finalmente, é por meio das declarações que dá aos jornais que o tenente Flaherty consegue provocar Rico e fazê-lo revelar seu esconderijo na sequência final do filme.

De fato, antes mesmo de ser figurado no cinema, o gângster já havia sido retratado tanto no jornalismo quanto na literatura. O próprio Al Capone admite ter lido livros sobre gângsteres, mas aponta uma ressalva importante:

Eu li um desses livros que estão no mercado agora, mas não tenho muito o que dizer a respeito. É bem escrito - até onde consegui perceber nas dez páginas do começo - mas é sobre outra pessoa. Esse livro diz tanto a meu respeito quanto um livro de Horatio Alger. ${ }^{93}$

A declaração de Al Capone corrobora a tese do historiador David E. Ruth de que o gângster como o conhecemos na indústria cultural é, na verdade, uma invenção, "muito menos um reflexo preciso da realidade do que uma projeção criada a partir de várias crenças americanas, interesses e ideias sobre o que poderia se tornar rentável"94. Segundo Ruth,

nos anos 1920 e início dos anos 1930, as inúmeras ofertas do gênero gângster estabeleceram o criminoso inventado como um dos símbolos da nova cultura de massa mais eminentemente poderosos e facilmente reconhecíveis. Os criadores do gângster deram a ele a tarefa de confrontar a sociedade urbana que ele representava. $\mathrm{O}$ vocabulário simbólico do gênero era uma rica fonte cultural que jornalistas, cineastas, e outros usaram em tentativas de explicar e alterar o comportamento dos americanos que habitavam os centros urbanos. (...) Assim como qualquer outra invenção de sucesso, o gângster tinha uma utilidade. Embora fosse impossível medir a aceitação popular de mensagens específicas, o fato é que o gângster era uma mercadoria muito rentável. ${ }^{95}$

\footnotetext{
${ }^{93}$ Capone, A. apud. Ruth, D. E. Inventing the public enemy: the gangster in American culture, 1914-1934. Chicago: The University of Chicago Press, 1996, p. 118. Horatio Alger (1832-1899) é conhecido no cenário da literatura infanto-juvenil norte-americana como um dos primeiros propagadores da ideologia do self-made man. Os protagonistas de seus romances eram garotos que saíam da miséria e alcançavam o "conforto da classe média" por meio da persistência e do trabalho árduo. (Cf. Clement, P. F.; Reinier, J. S. (ed.). Boyhood in America: An Encyclopedia, Volume 1. Santa Barbara: ABC-Clio, 2011, p. 36).

${ }^{94}$ Ruth, D. E. Inventing the public enemy: the gangster in American culture, 1914-1934. Chicago: The University of Chicago Press, 1996, p. 1.

${ }^{95}$ Ibidem, p. 4.
} 

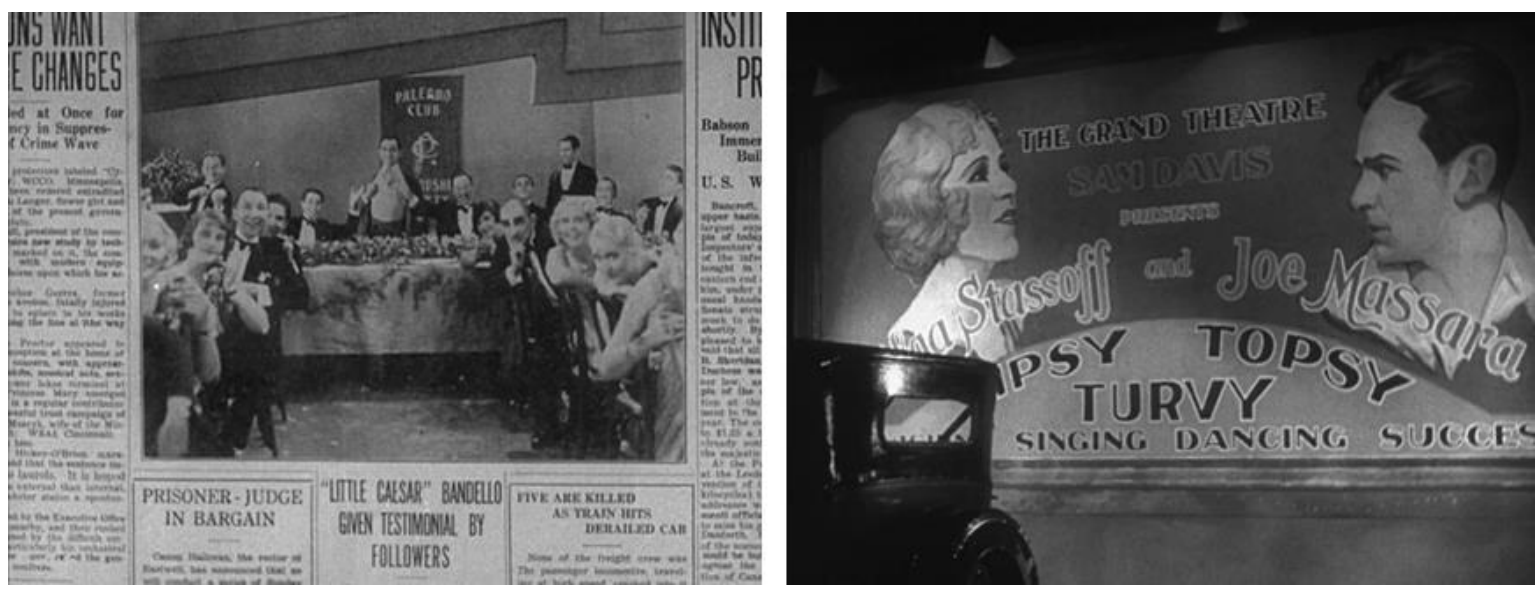

Figura 9 - Duas figurações da indústria cultural em Little Caesar: o jornal em close com destaque para a foto do banquete em homenagem a Rico (esq.) e o painel de anúncio do espetáculo com Olga e Joe na última cena do filme.

Dessa maneira, não interessava aos jornais ou a Hollywood se a figuração do gângster era próxima ou não da realidade, mas sim que ela chamava a atenção do público, o que gerava lucro.

\begin{abstract}
A gangue é um negócio dentro do gênero [gângster], mas um tipo muito especial de negócio criado dentro da ficção Americana e em Hollywood. A estrutura corporativa da gangue, assim como o registro da vida do gângster em si, não corresponde ao gângster real e não são relevantes para o gênero ou à sua necessidade de verossimilhança, qualquer que seja o conceito de "real" utilizado. ${ }^{96}$
\end{abstract}

A estratégia publicitária da indústria cultural, no entanto, era a de atestar a veracidade dos fatos, fossem eles as notícias de jornal ou os filmes. Um bom indício dessa estratégia pode ser visto no texto divulgado pela Warner Bros. na ocasião do lançamento de Blondie Johnson (1933), de Ray Enright:

Quando historiadores sérios começarem a juntar as peças que formam os nossos tempos modernos, eles agradecerão particularmente a quatro pessoas: James Cagney, Edward G. Robinson, Paul Muni e Joan Blondell. Esses quatro atores, mais do que qualquer um, estão fornecendo às futuras gerações uma representação fiel dos maiores problemas de nosso tempo através do cinema. Esses futuros escritores podem chamar nossa época de era dos ladrões, os anos em que a juventude do mundo enlouqueceu, revoltada contra a lei e a disciplina, ou eles podem fazem referência à era dos gângsteres, quando as forças da lei sofreram um

${ }^{96}$ Kaminsky, S. M. Little Caesar and its Role in the Gangster Film Genre. In: Philadelphia: Journal of Popular Film, Vol. 1, Iss. 3, 1972, p. 219. 
eclipse. Qualquer que seja o nome que derem, qualquer que seja a explicação, as representações mais fiéis de todo esse estranho fenômeno internacional serão fornecidas pelos então antigos rolos de filmes conhecidos pelos nomes de "The Public Enemy", "Little Caesar", "Scarface" e "Blondie Johnson”. O valor atual desses filmes é de entretenimento, mas, para futuros historiadores, eles servirão como fontes de inestimável valor. ${ }^{97}$

Não podemos dizer que a previsão da Warner Bros. em 1933 estava totalmente equivocada, uma vez que a própria existência do presente trabalho corrobora parte de sua tese. Por outro lado, nosso objetivo como críticos é questionar a fidelidade na representação da realidade que os produtores de filmes como Little Caesar alegavam promover na década de 1930. Um dos pontos mais interessantes nessas produções é justamente o conflito entre a realidade da violência urbana no início do século XX nos EUA e o mecanismo da indústria cultural, que vendeu ao público consumidor da época um acúmulo de diversas camadas de ideologia sobre aquela realidade. Segundo Theodor Adorno, "o mundo inteiro é forçado a passar pelo crivo da indústria cultural" ${ }^{98}$. Na avaliação do crítico alemão,

a velha experiência do espectador cinematográfico, para quem a rua lá de fora parece a continuação do espetáculo que acabou de ver - pois este quer precisamente reproduzir de modo exato o mundo percebido cotidianamente tornou-se o critério da produção. Quanto mais densa e integral a duplicação dos objetos empíricos por parte de suas técnicas, tanto mais fácil fazer crer que o mundo de fora é o simples prolongamento daquele que se acaba de ver no cinema. $^{99}$

Em Little Caesar, a combinação da tentativa da indústria cultural de reproduzir o mundo percebido cotidianamente com a ideologia do American Dream faz a narrativa ser lacunar na ascensão do protagonista dentro do mundo dos negócios. Rico ascende ao poder quase como resultado de sua personalidade: ele é o mais forte, mais audacioso, mais corajoso e, portanto, mais apto dentro da lógica corporativa do crime organizado a assumir um papel de responsabilidade entre seus pares. Sob o ponto de vista dramático, contudo, a construção dessa ascensão é rápida e sem muitos obstáculos, o que é facilmente perceptível na discussão

\footnotetext{
${ }^{97}$ Ruth, D. E. Inventing the public enemy: the gangster in American culture, 1914-1934. Chicago: The University of Chicago Press, 1996, p. 5.

98 Adorno, T. "A indústria cultural - o Iluminismo como mistificação das massas”. In: Indústria cultural e sociedade. São Paulo: Paz e Terra, 2002, p. 15.

${ }^{99}$ Ibidem, p. 15-16.
} 
que Rico tem com Vettori sobre a divisão dos lucros do roubo ao Bronze Peacock. Logo após serem interrogados pelo tenente Flaherty sobre a morte do comissário de polícia durante o assalto, Rico sai de seu esconderijo com os sacos de dinheiro na mão. $O$ gângster se dirige à mesa de Sam Vettori e começa a separar o dinheiro. O enquadramento em plano médio mostra Rico em pé à esquerda, e Vettori, sentado à mesa à direita:

Vettori: [esticando o braço em direção ao dinheiro] Deixe-me ver a cor do dinheiro.

Rico: Só um minuto, Sam. Eu tenho o meu próprio jeito de dividir a grana dessa vez. E você pode aceitar ou cair fora. Ninguém está te pedindo nada.

Vettori: [levanta-se da cadeira e levanta a voz]: Eu fui o chefe desse trabalho. E nós vamos dividir a grana do jeito de sempre e...

Rico: [em close, interrompendo Vettori e também levantando a voz] Como você chefiou esse trabalho? Ficando aqui sentado jogando paciência? Isso não vai ser mais assim, já chega! Já recebi ordens suas por muito tempo...

Vettori [novamente em plano médio]: Você vai continuar recebendo minhas ordens... Ou você vai dar o fora daqui tão rápido que...

Rico: Talvez não seja eu que dê o fora.

Vettori: Ah, é? Talvez os rapazes tenham algo a dizer sobre isso. [olhando para fora do enquadramento] $\mathrm{E}$ então? [há um corte para um plano geral que mostra o restante da gangue se abstendo de qualquer comentário. Novo corte para um plano americano de Vettori, que se senta à mesa, derrotado] Então é assim?

Rico: [em close] Isso mesmo. Você fala o que quer, mas não aguenta ouvir o que não quer. Acabou pra você. [corte para o plano médio inicial] E então?

Vettori: [resignado] Tudo bem por mim, Rico.

Rico: E quanto a vocês, rapazes? [olhando para os outros] Sem mágoas, Sam. [Rico anda até Vettori e o agarra pelo braço. Há um corte para um plano americano] Precisamos permanecer unidos. Tem uma corda no meu pescoço agora, e eles só te enforcam uma vez. [olhando para os outros] Se alguém se acovardar e abrir o bico, minha arma vai selar a paz.

Mesmo que anteriormente o filme mostre algumas atitudes de insubordinação de Rico à liderança de Vettori, a rapidez na evolução do personagem - de capanga recém-aceito na gangue a líder soberano - reitera a mensagem cara à sociedade burguesa norte-americana de que basta ao cidadão comum - mais especificamente, à classe trabalhadora - o "perfil de liderança" e "espírito empreendedor" para "ser alguém na vida". O filme nos mostra, no entanto, que a junção harmônica da representação fidedigna da realidade com o American Dream é impossível. 


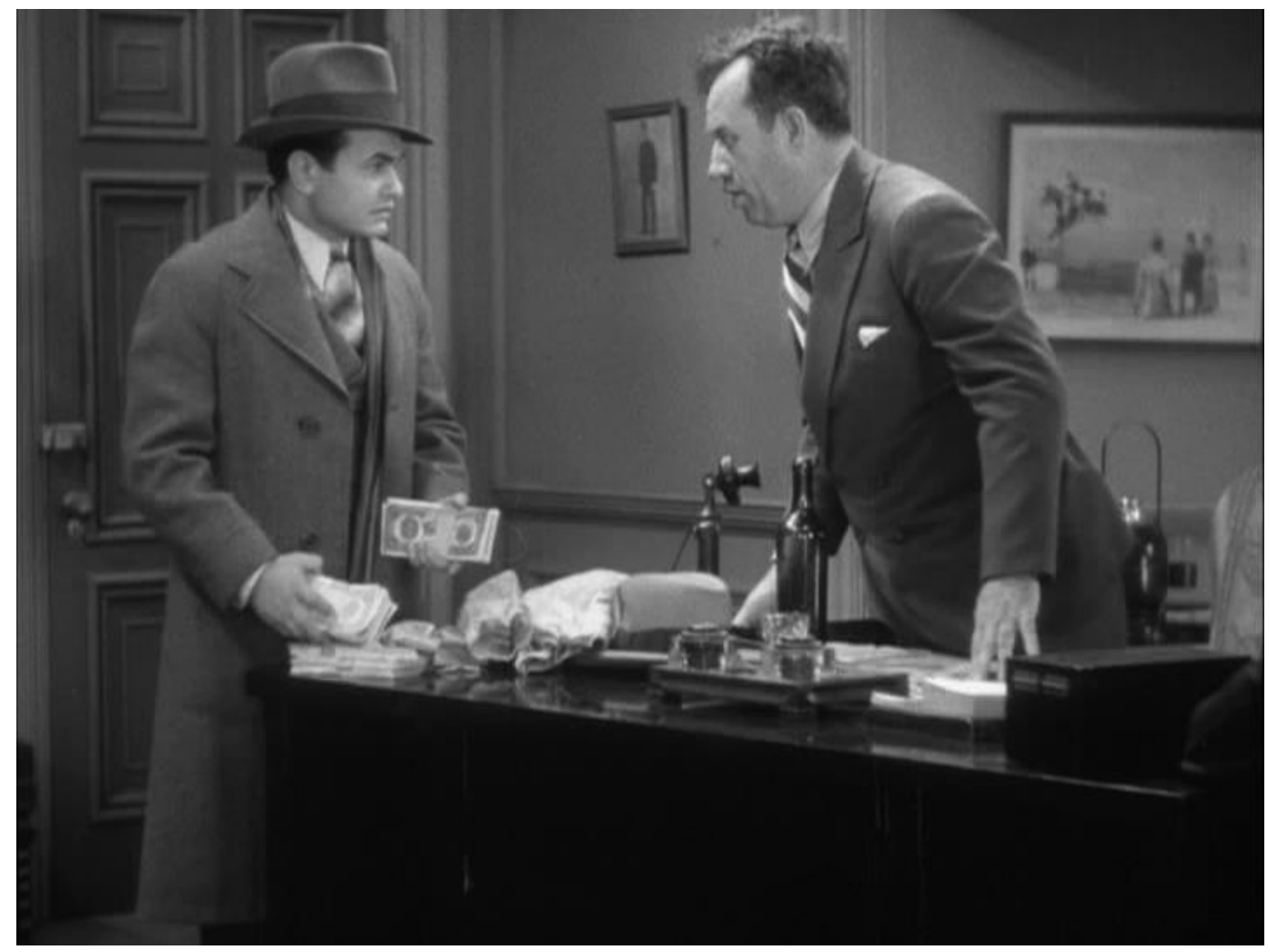

Figura 10 - Rico e Vettori discutem sobre a divisão os lucros

\section{A tragédia da classe trabalhadora}

Uma das características determinantes na escolha de Robinson para o papel de protagonista de Little Caesar foi sua baixa estatura $(1,67 \mathrm{~m})$, que criou uma rima visual com o título do filme. Título, aliás, que não é irônico por acaso, pois a ascensão de Rico (ou Caesar Enrico Bandello) traça um paralelo em relação à ascensão de uma figura histórica real, um imperador:

O César de Shakespeare é apresentado com uma visão conscientemente elevada do homem sobre si mesmo. O Caesar de Mervyn LeRoy, por sua vez, está propositadamente sob uma visão em escala reduzida de si próprio e sua tragédia. O filme de LeRoy, em contraste com a peça de Shakespeare, tinha como públicoalvo espectadores das classes baixa e média, e foi concebido como uma obra de entretenimento popular construída com critérios amplos de comportamento vulgar e imagens que trariam ao espectador um reconhecimento social. Parte da ironia da 
situação em um filme de gângster é que ele pensa que está operando em grande escala. ${ }^{100}$

Embora as escalas sejam de fato diferentes, tanto "Júlio César" como Little Caesar são tratadas por Kaminsky como narrativas trágicas. O crítico cultural Robert Warshow também havia definido, em 1948, o filme de gângster como uma "tragédia moderna" em meio a uma indústria cultural comprometida com a propagação fútil de imagens de otimismo e esperança que, segundo Warshow, não satisfazem a ninguém:

\footnotetext{
Mesmo dentro do campo da cultura de massa, sempre existe uma corrente de oposição que procura expressar, por quaisquer modos disponíveis, a sensação de desespero e fracasso inevitáveis que o próprio otimismo ajuda a criar. (...) Quando se entra no campo da arte, [essa oposição] normalmente é disfarçada ou atenuada: em uma forma de expressão inespecífica como o jazz, no niilismo inofensivo dos irmãos Marx, na reiterada falta de esperança, que muitas vezes parece ser o real significado das soap operas. O filme de gângster é notável porque preenche a necessidade do disfarce (embora não o suficiente para evitar um mal-estar) sem exigir nenhuma distorção mais grave. Desde o início, ele tem sido uma consistente e impressionante apresentação completa do sentido moderno de tragédia. ${ }^{101}$
}

Sob o mesmo ponto de vista de Warshow, o crítico português Eduardo Geada afirma que a morte do criminoso ocorre porque,

depois de chegar ao topo do poder, da fortuna e da corrupção, [o criminoso] já não tem lugar para onde ir. A actividade feroz e implacável do gangster é um exemplo típico da história de sucesso num mundo onde impera a lei da selva urbana: ele liquida sem contemplações todos os obstáculos que o podiam impedir de triunfar na vida. Morto entre sarjetas e caixotes de lixo, o gangster não é punido tanto pelos crimes que cometeu, e que lhe deram prazeres inconfessáveis, como pela ousadia de ter conseguido sair do anonimato, da subserviência e da penúria. O gangster é uma figura trágica da modernidade capitalista porque morre justamente no momento em que celebra a glória do triunfo, pondo em causa o mito do sonho americano. ${ }^{102}$

\footnotetext{
${ }^{100}$ Kaminsky, S. M. Little Caesar and its Role in the Gangster Film Genre. In: Philadelphia: Journal of Popular Film, Vol. 1, Iss. 3, 1972, p. 211.

${ }^{101}$ Warshow, R. The gangster as a tragic hero. In: Silver, A., Ursini, J. Gangster Film Reader. Pompton Plains: Limelight Editions, 2007, p. 12.

${ }^{102}$ Geada, E. Os mundos do cinema. Lisboa: Editorial Notícias, 1998, p. 236.
} 
Vale notar que conceito de "tragédia" utilizado pelos autores citados anteriormente não é unanimidade entre os acadêmicos. No prefácio à "Tragédia Moderna" de Raymond Williams, a crítica Iná Camargo Costa ressalta que

\begin{abstract}
acidentes de automóvel, explicavam eles [os acadêmicos britânicos], pelo simples fato de serem acidentes, envolvendo "gente comum", não podem ser chamados de trágicos. Recorrendo ao seu conhecido método de historicizar conceitos (...), o professor [Raymond Williams] mostra que só por preconceito aristocrático teríamos que recusar, como quer a academia, o processo histórico cifrado na assimilação do conceito de catástrofe pelo de tragédia. Afinal, pergunta ele, por que deixar o conceito confinado a uma academia que nem sequer se mostrou capaz de preservar o saber que ele envolve? Por outro lado, a recusa em usá-lo, ou pior, a censura em seu uso corresponde a mais uma tentativa de desqualificar a experiência da gente comum: desastres de automóvel ou de trem, perda de emprego, desabamento em minas, quedas de vigas, explosões em plataformas marítimas são trágicos para suas vítimas. Com base nesse fato, se tivermos o cuidado de ultrapassar o aspecto fatalista que impregnou o conceito ao longo de sua história, nada impede que também a situação de ameaça e falta de alternativas em que se encontra hoje a humanidade seja qualificada como trágica. ${ }^{103}$
\end{abstract}

Dentro desse conceito mais amplo, é possível ver em Little Caesar uma tragédia tanto quanto em "Julio César". A diferença, como comentado anteriormente, está na escala em que as ações ocorrem. Enquanto a peça de Shakespeare narra a conspiração contra o ditador Julio César, seu assassinato e as consequências de sua morte para o Estado romano, Little Caesar narra a trajetória de Rico em busca da admiração do submundo por suas conquistas. Se em "Julio César" a luta é pelo poder do Estado romano, em Little Caesar a luta é pelo poder nas ruas de Chicago nos anos 1930. Finalmente, enquanto o texto de Shakespeare é protagonizado pelos patrícios romanos, que compunham o topo da pirâmide social, tanto o romance de Burnett como o filme de Mervyn LeRoy têm como personagens principais membros da classe trabalhadora. Nesse sentido, afirma Kaminsky, o "little" do título ressalta "um contraste entre as aspirações da figura trágica e as possibilidades da situação. (...) Se Rico é um César, ele é, de fato, um pequeno César, pequeno na possibilidade de suas conquistas e pequeno em tamanho"104.

${ }^{103}$ Costa, I. C. Tragédia no século XX. In: Williams, R. Tragédia moderna. São Paulo: Cosac Naify, 2011, p. 15.

${ }^{104}$ Kaminsky, S. M. Little Caesar and its Role in the Gangster Film Genre. In: Philadelphia: Journal of Popular Film, Vol. 1, Iss. 3, 1972, p. 213. 
De fato, o horizonte de possibilidades do protagonista de Little Caesar é reduzido, mas o é porque a narrativa privilegia as escolhas e as ações individuais criminosas de Rico em detrimento de possíveis ações coletivas da classe à qual ele pertence, como a luta organizada pela posse dos meios de produção. De maneira análoga, a tragédia de Rico tem tamanho reduzido perto da tragédia que vivia a classe trabalhadora nos anos da Depressão.

Um último aspecto que corrobora a classificação de Little Caesar como uma tragédia é a maneira como o enredo se encaixa no conceito de ironia trágica. Dentro da tragédia, o herói recebe um oráculo, descobre que vai ser destruído e toma várias ações para que isso não aconteça. Ironicamente, a tomada de tais ações provoca a sua ruína, pois o destino é mais forte do que a sua vontade de escapar. Segundo o crítico Patrick Pessoa,

\begin{abstract}
a ironia da ação trágica é o que permite diferenciar a idéia de destino propriamente trágica da idéia de destino presente nos mitos que a tragédia toma como matériaprima. Enquanto nos mitos o destino aparece como uma espécie de necessidade cega, de violência em estado bruto que arrasta gratuitamente o herói, apresentado como marionete dos deuses, na tragédia não há tal passividade. A queda do herói, para ser trágica, precisa em alguma medida ser auto-infligida. A ironia da ação trágica, como bem mostrou Peter Szondi em seu ensaio sobre Édipo Rei, repousa sobre "a unidade de salvação e destruição. A destruição em si não é trágica, mas sim o fato de que a salvação vire destruição. $O$ trágico não se consuma com a queda do herói, mas sim com o fato de o homem naufragar no caminho que tomou justamente para escapar ao naufrágio”. (...) Se, sob a perspectiva do herói, não é possível apreender que todas as suas ações o conduzem justamente na direção contrária a que pretendia ir (...) então é forçoso concluir que a ironia da ação trágica só se torna visível a partir da ironia do autor, ou, conforme o caso, do espectador da tragédia. Isso, aliás, é o que Aristóteles indica na Poética quando afirma que sem Reconhecimento não há tragédia. Édipo só apreende a tragicidade de sua situação quando se torna um espectador de si mesmo. ${ }^{105}$
\end{abstract}

O oráculo de Rico é a indústria cultural, representada pelo jornal que o personagem encontra no balcão do restaurante na primeira cena. $O$ gângster interpreta a notícia sobre a homenagem a Pete Montana como um aviso: seu destino é o ostracismo que ele tanto rejeita. Rico decide, então, fugir para a cidade grande, onde as oportunidades de "ser alguém na vida" são mais concretas. Apoiando-se na ideologia do empreendedorismo e da livre

${ }^{105}$ Pessoa, P. A ironia trágica de Machado de Assis. In: Viso - Cadernos de estética aplicada. Rio de Janeiro, Vol. I, n 1 , jan-abr/2007, p. 3-4. 
iniciativa, o protagonista tem a ilusão de que é capaz, por conta das suas ações individuais, de manipular o sistema em seu favor, apenas para descobrir ao final que suas ações foram irônicas: tudo o que ele fez para ascender foi responsável pela sua queda. O gângster, entretanto, é o único que acredita no próprio sucesso, pois o espectador conhece as convenções do gênero e sabe que o bandido sempre morre no final. A última cena do filme, em que Rico exclama: “Misericórdia! Esse é o fim de Rico?", é o momento de reconhecimento aristotélico da tragédia em Little Caesar.

\section{Aparência e essência}

Um dos momentos mais emblemáticos do êxito alcançado por Rico em Little Caesar se dá no banquete em sua homenagem que seus amigos e subordinados oferecem - assim como aquela oferecida a "Diamond" Pete Montana descrita pela manchete do jornal que o protagonista lê no início do filme. A sequência da festa tem início com um close de um cartaz com os dizeres: "Palermo Club - Amizade e Lealdade". Há um corte, e o plano seguinte registra Rico mostrando para Vettori, à sua esquerda, uma brochura comemorativa do banquete, com uma foto sua e mensagens de seus amigos. A mensagem que Vettori deixou é lida em voz alta por Rico: "Felicitações a um verdadeiro amigo, Sr. C. Bandello, de um verdadeiro amigo, Sr. Sam Vettori”.

Há um corte e o plano seguinte mostra, em dolly shot, da esquerda para a direita, as mesas com os convidados conversando e comendo. O enquadramento mostra Pete Montana à direita de Rico, e o restante de seus colegas de gangue à esquerda, ao lado de Vettori. Após o corte, um plano geral mostra o salão onde ocorre o banquete. Há uma algazarra generalizada entre os convidados, que falam alto, levantam-se da mesa e jogam pedaços de comida uns nos outros. Nesse momento, Vettori se levanta e grita, pedindo silêncio: "Qual o problema de vocês? Não sabem se comportar em um banquete? Parece um bando de viralatas! Chega de papo. Scabby vai fazer um discurso!".

Há um corte e a câmera mostra Scabby, visivelmente embaraçado com a situação, se levantando. Os convidados aplaudem e festejam o discurso, e Scabby começa a falar: 
Scabby: Bem, pessoal... vocês todos sabem por que estamos aqui, então não preciso ficar explicando, certo? O Rico é um grande sujeito!

Todos aplaudem, e Rico aparece em close acenando e agradecendo os aplausos. A câmera volta para Scabby, que retoma o discurso:

Scabby: Sim, e... Bom... [sem saber como continuar, demonstrando desconforto] Olha, Rico, não sei falar bonito, mas [Scabby tira um relógio do bolso e mostra para Rico; há um corte para mostrar o relógio em close] esse relógio aqui é pra você. De todos nós!

Ouve-se em voz-over o aplauso de todos, enquanto o relógio é entregue a Rico, que aparece em close outra vez mostrando o presente orgulhosamente para os outros à sua volta. Os convidados, então, pedem que Rico faça um discurso. Ele reluta, mas se levanta, tira o guardanapo preso em seu colete e começa a falar:

Rico: OK, tudo bem... Vocês querem que eu faça um discurso, então aqui vai. Quero agradecer a todos vocês por esse banquete. Está ótimo. A bebida está boa, foi o que me disseram. Mas eu não bebo. E a comida também não deixa nada a desejar. Acho que estamos todos tendo uma ótima noite... E é bom ver vocês todos com suas garotas aqui. É, bem... [mostrando embaraço] Acho que é isso! [todos aplaudem, Rico se senta, mas torna a se levantar] Eu só gostaria que vocês não bebessem demais, porque é assim que muita gente acaba mal. [todos riem] 


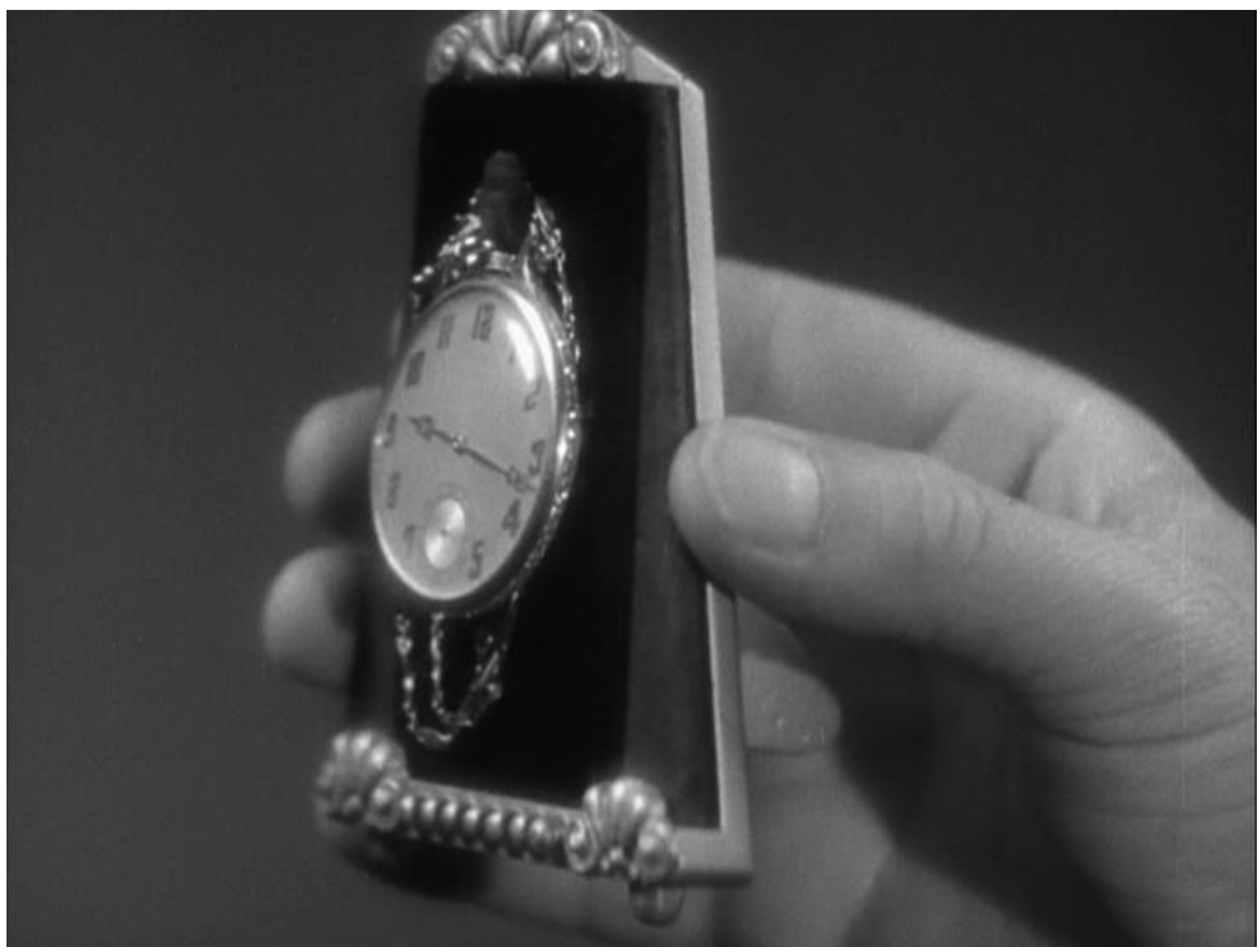

Figura 11 - O relógio que rico ganha de presente de seus amigos.

Nesse momento, um dos funcionários do Palermo Club aparece e avisa a Rico que os fotógrafos do jornal querem tirar uma foto. Rico manda os fotógrafos entrarem, tira um pente do bolso e começa a arrumar o cabelo. Nesse momento, Pete Montana se levanta e diz a Rico que volta depois, pois ele não deixa tirarem uma foto sua há quinze anos. Rico estranha o fato, mas deixa Pete sair. Os fotógrafos, então, entram no salão. Rico põe os polegares sob o colete e estufa o peito para a foto.

Assim que a foto é tirada, Pete Montana volta para o seu lugar e diz a Rico que aquela foto pode lhe causar problemas no futuro, ao que o protagonista prontamente responde: "Ora, qual o problema? Quero que as pessoas vejam o que os rapazes pensam de mim". Vettori, então, pergunta a Rico:

Vettori: Ei, Rico, que fim levou aquele seu amigo, o dançarino, Joe Massara?

Rico: [em close, pensativo] Ele não veio. [pausa] Ele não aparece há muito tempo.

Vettori: [em voz-over] Ele não te deixou, né, Rico?

Rico: Ele não seria burro de fazer isso. Um cara tentou me abandonar antes. Agora, cuide da sua vida e deixe que eu cuido da minha. 


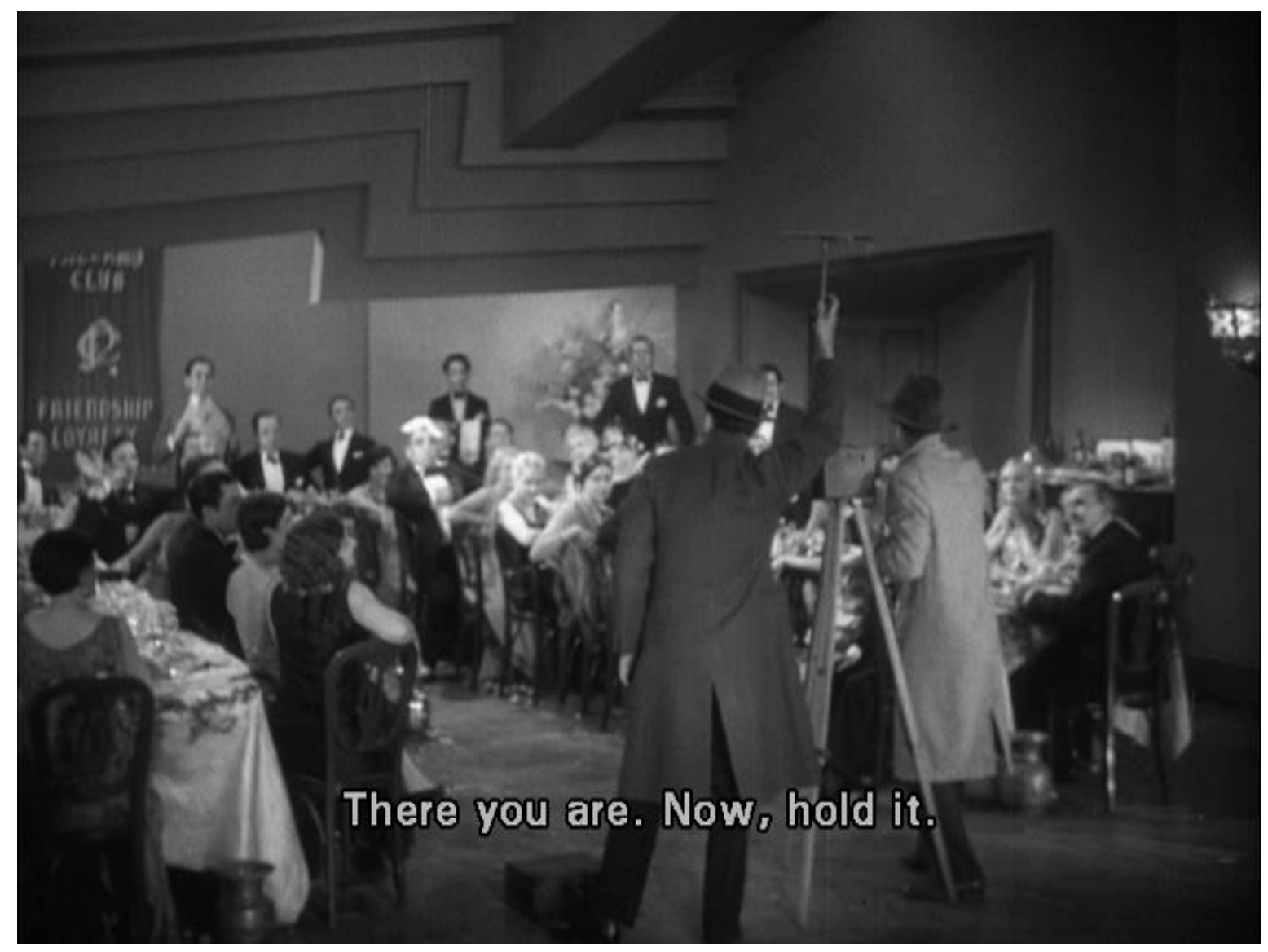

Figura 12 - Rico sendo fotografado durante o banquete em sua homenagem.

Na sequência, o tenente Flaherty entra de surpresa no salão e diz a Rico em tom irônico que fica feliz por ele estar "subindo na vida", e aproveita para perguntar-lhe se não sabe de nenhum relógio que havia sido roubado na noite anterior. Flaherty vai embora e Rico, ao descobrir a origem do relógio que ganhou minutos atrás, olha com reprovação para o restante da gangue.

Vários dos elementos dessa sequência - as homenagens por escrito na brochura, o relógio que Rico ganha de presente, os discursos e a fotografia para o jornal, além do banquete em si - materializam não só o acúmulo de poder e riqueza pelo protagonista, mas também sua sede de nomeada. Em outras palavras, não basta ao protagonista ter espírito empreendedor e conquistar sua independência financeira, é preciso criar uma imagem social vencedora e ser reconhecido pelos outros como uma pessoa de sucesso. Para Rico, mais do que ser um vencedor, é preciso parecer um vencedor.

O principal veículo pelo qual se dá o "prestígio imediato" das aparências de Rico é a indústria cultural, na figura do jornalismo. No dia seguinte ao banquete, o protagonista pede ao jornaleiro dez cópias do jornal com sua foto na capa. O registro foto-jornalístico da festa 
é, em certa medida, mais importante para Rico do que o banquete em si, pois, além de divulgar em larga escala seus feitos, também legitima a ascensão do gângster à "alta sociedade", da qual ele desesperadamente quer fazer parte. Outro aspecto importante da foto de Rico no jornal é demonstrar como o criminoso - e o universo da ilegalidade em si - está totalmente integrado à sociedade legal. Segundo o teórico Ernest Mandel,

um filósofo produz ideias; um poeta, poemas; um sacerdote, sermões; um professor, compêndios; e assim por diante. Um criminoso produz crimes. Se olharmos mais de perto a relação entre esse último segmento e a sociedade como um todo, podemos nos livrar de muitos preconceitos. O criminoso produz não só crimes, mas também o código penal, o professor que dá aulas sobre direito criminal, e, finalmente, o inevitável compêndio no qual esse mesmo professor publica suas aulas no mercado editorial como "mercadorias". (...) O criminoso, além disso, produz toda a polícia e justiça criminal, policiais, juízes, executores, jurados, etc.; e todas essas diferentes linhas de negócios, que formam igualmente muitas categorias de divisão social do trabalho, desenvolvem diferentes capacidades do espírito humano, criam necessidades e novas formas de satisfazêlas. (...) O criminoso rompe a monotonia e a segurança do cotidiano da vida burguesa. Dessa maneira, ele impede que ela fique estagnada, e dá origem àquela tensão inquietante maior até do que o estímulo da competição. Assim, ele estimula as forças produtivas. Enquanto o crime tira uma parte supérflua da população do mercado de trabalho, e, dessa forma, reduz a competição entre os trabalhadores prevenindo que os salários caiam abaixo do mínimo - a luta contra o crime absorve outra parte dessa população. Dessa forma, o criminoso funciona como um “contrapeso" natural, que traz equilíbrio e cria oportunidades para uma ampla gama de ocupações "úteis”. 106

Mandel nos chama a atenção para a relação simbiótica entre o crime e o sistema produtivo. Se por um lado o crime depende do exército de reserva - gerado sobretudo em momentos de crise - para sobreviver, por outro lado certas ocupações dependem da ação criminosa. Em Little Caesar, por exemplo, podemos notar a quantidade de ocupações que surgem direta ou indiretamente do gangsterismo. Além dos policiais que perseguem a gangue ao longo do filme, também sobrevivem do crime organizado todos os trabalhadores envolvidos com o funcionamento dos clubes Palermo e Bronze Peacock (crupiês, garçons, balconistas, gerentes, dançarinos); os colunistas sociais, jornalistas e fotógrafos da imprensa

106 Mandel, E., Delightful Murder - A social history of the crime story. Minneapolis: Univeristy of Minnesota Press, 1984, p. 10. 
local; o comércio de armas; os serviços funerários; os mordomos de grandes chefes como Big Boy, entre outros. Tais ocupações mostram ao espectador de Little Caesar que não existe um "submundo do crime"; pelo contrário, o gangsterismo é parte fundamental do sistema produtivo.

Dessa maneira, podemos dizer que o gangsterismo é uma atividade comercial plena, que cria empregos e faz o capital circular ao seu redor. Ao registrar o crime organizado não como exceção, mas como regra dentro do capitalismo, Little Caesar nos oferece um potencial crítico importante, pois revela um paradoxo: ao mesmo tempo em que pune o crime - que mantém o equilíbrio do sistema produtivo ao empregar tanta mão-de-obra -, a sociedade legal depende dele para que o exército de reserva gerado pela crise econômica não se organize coletivamente e reivindique mudanças no status quo.

Voltando à questão das aparências em Little Caesar, é possível notar no comportamento de Rico a percepção de que no palco da vida social não basta ter dinheiro, é preciso demonstrar que você o possui. É com essa finalidade que suas primeiras providências, assim que inicia sua trajetória dentro da gangue, se dão no âmbito do consumo: ternos caros, chapéus, sapatos, anéis de diamante, charutos, entre outros adornos, passam a fazer parte de seu vestuário.

O fascínio que Rico tem pelas aparências - e também pelas mercadorias - surge de maneira reiterada ao longo da narrativa através do close em diferentes objetos de valor, como o que ocorre com o relógio na sequência do banquete descrito anteriormente.
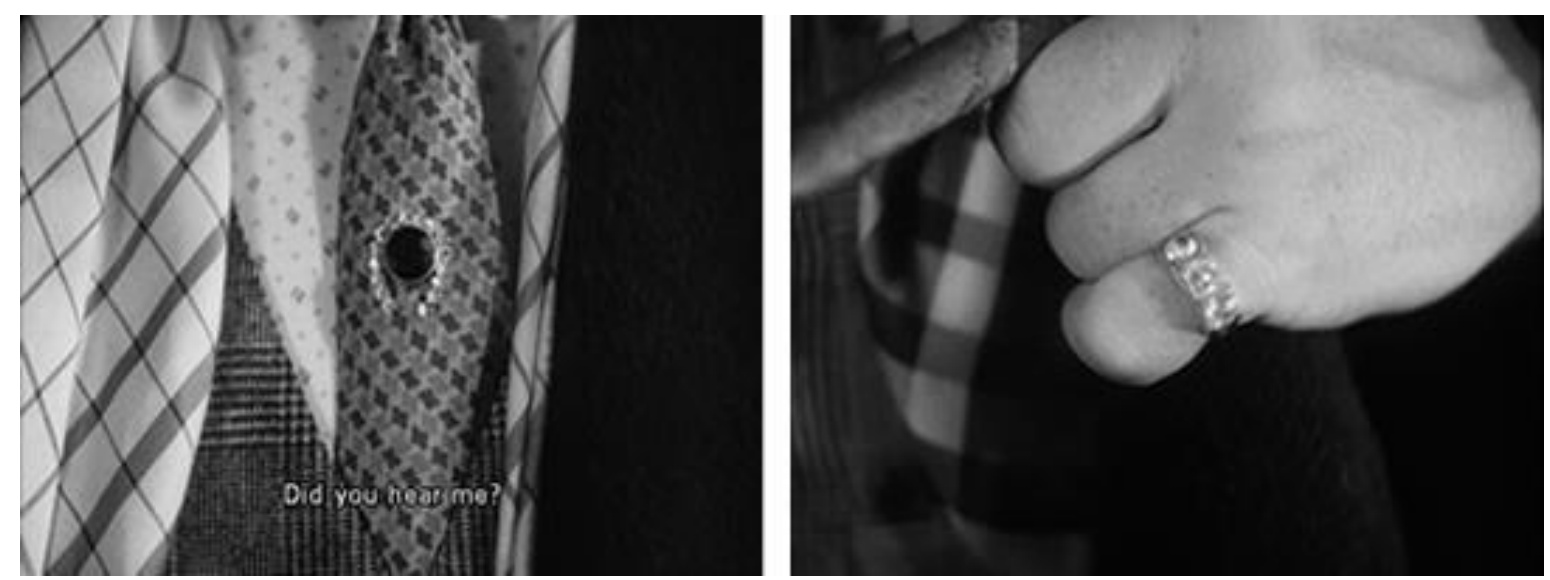

Figura 13 - Closes em diferentes mercadorias ao longo do filme. 
Tal procedimento técnico enfatiza o fetiche de Rico por determinadas mercadorias que simbolizam seu avanço na hierarquia da gangue - por meio da montagem das cenas e da repetição da técnica, o espectador consegue relacionar ao protagonista todos os momentos em que esse recurso é utilizado.

Embora os closes nas mercadorias possam parecer, a princípio, um indício de que o filme segue o ponto de vista de Rico, o protagonista é utilizado em Little Caesar como objeto de observação. Não há no filme uma identificação formal, nem tampouco psicológica com Rico, porque ele é apresentado como um personagem antipático, feio, rude, que não conquista nossa adesão. Faz parte da intenção moralizante do filme que o gângster permaneça como objeto de observação a fim de que seja possível fazer um julgamento moral a cada instante. Ocorre que o distanciamento necessário para o julgamento moral também serve para o julgamento político. Dessa forma, mesmo sob o limite das convenções hollywoodianas, é possível captar questões impostas pela força da matéria histórica.

O auge do fascínio de Rico pelas aparências se dá na cena em que ele prova o terno que utilizará em seu primeiro encontro com Big Boy, o homem que controla todas as gangues de Chicago. O plano médio se mantém fixo do início ao fim da cena, mostrando Otero, um dos integrantes da gangue, em primeiro plano à esquerda, e o reflexo do corpo inteiro de Rico à direita. O gângster está em pé sobre uma mesa ou um tablado. No início da cena, Otero aparece no espelho junto de Rico, ajeitando seu terno. O protagonista limpa o suor da testa e se sente visivelmente incomodado com a roupa:

Rico: Eu não sei... [Otero se afasta para observar Rico de longe, e aparece de frente para a câmera]

Otero: Você está ótimo, chefe!

Rico: É, mas eu me sinto péssimo! [ajeitando a roupa]

Otero: Oh, você está subindo na vida, Rico! Nenhum de nós já foi convidado para jantar na casa do Big Boy. E nunca ninguém entrou lá, a não ser Pete Montana. Entende o que eu estou dizendo? Você não quer que o Big Boy pense que você não tem classe.

Rico: [olhando para o espelho] Na prisão nos dão roupa melhor do que essa. [dirigindo-se a Otero] Se você acha que vou sair vestido desse jeito, está maluco. [começa a descer da mesa]

Otero: [rapidamente] Você está ótimo, chefe! Vamos lá, dê uma bela olhada.

Rico: [subindo de volta para a mesa e resmungando] Ah, eu não sei. [olha-se no espelho] Só preciso de um guardanapo no meu braço. [ajeita a gola da camisa] Otero: [empolgado] E então? Não ficou bom? 
Rico: [mexendo na roupa, com a fisionomia mais alegre] É, talvez eu não esteja tão mal assim. [Otero abre um largo sorriso]

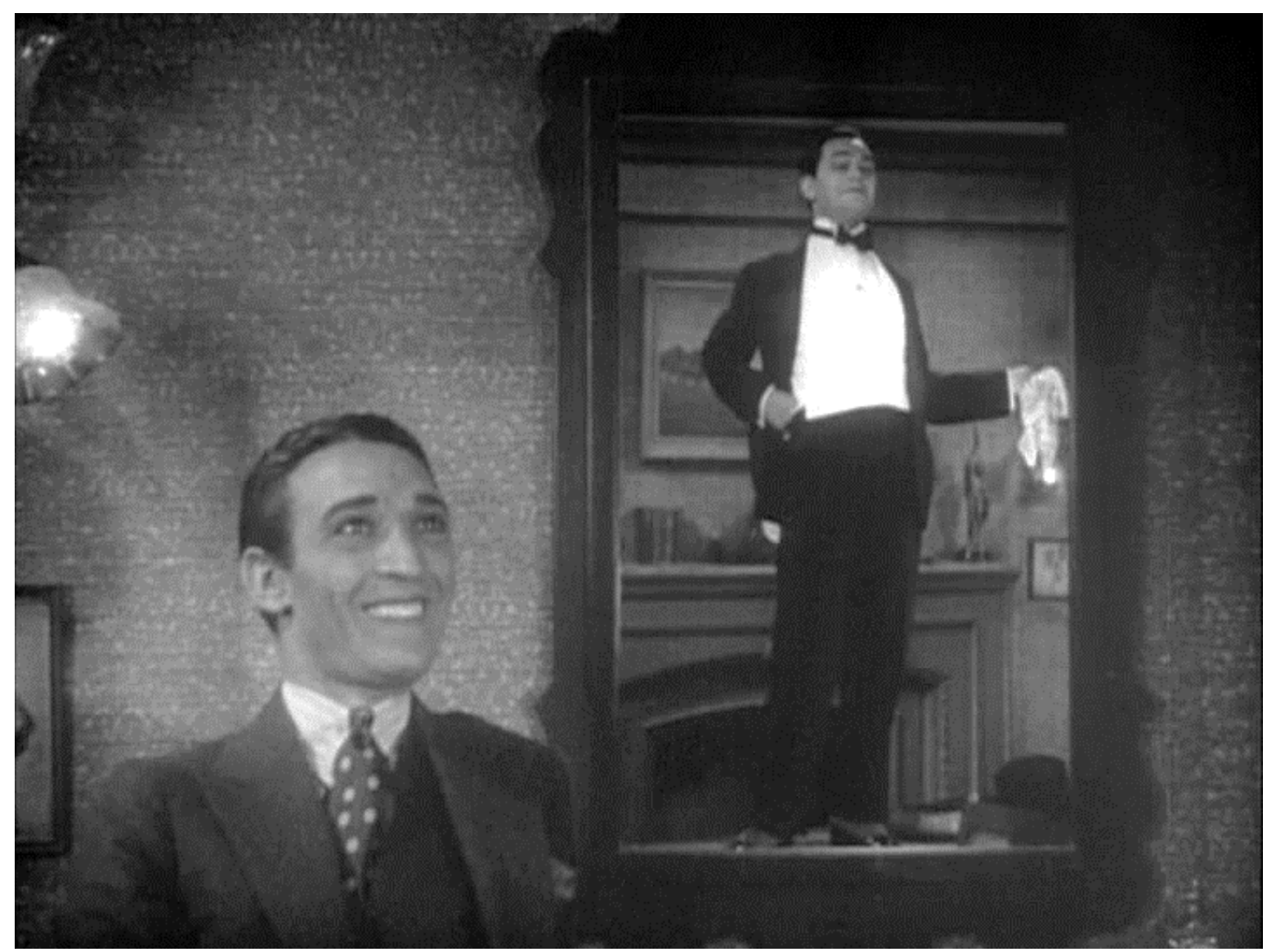

Figura 14 - Otero admira Rico provar seu terno.

É interessante notar o destaque que se dá nessa cena ao espelho, que ocupa praticamente metade do enquadramento; o reflexo - ou a aparência - de Rico é mais importante do que o gângster em si. A composição visual do quadro contribui para a sensação de restrição de movimentos do protagonista - além de Rico estar literalmente enquadrado na cena, ele reclama do desconforto da roupa e da sensação de ridículo ao se ver vestido daquela maneira. Curiosamente, no começo do filme, Rico explica a Joe que "quer ser alguém na vida" para poder fazer as coisas "do jeito dele ou nada". A cena da prova da roupa em Little Caesar, entretanto, nos mostra o quanto o protagonista é obrigado a se adaptar à roupa, e não o contrário. Se levarmos em conta que o sonho do gângster era ampliar seu campo de ação por meio da livre iniciativa, a composição visual dessa cena nos mostra, em primeiro lugar, a ironia da trajetória do protagonista, que se vê obrigado a se submeter às estruturas, códigos e rituais rígidos do convívio social burguês; e em segundo lugar, o processo de reificação do 
personagem, sua transformação em pura imagem. De acordo com Jameson,

\begin{abstract}
a forma última da reificação mercantil na sociedade de consumo contemporânea é precisamente a própria imagem. Com essa mercantilização universal de nosso mundo objetivo, os conhecidos relatos sobre a direção-para-o-outro do consumo habitual contemporâneo e a sexualização de nossos objetos e atividades são também indícios: o novo carro da moda é essencialmente uma imagem que outras pessoas devem ter de nós e consumimos menos a coisa em si que sua ideia abstrata, aberta a todos os investimentos libidinais engenhosamente reunidos para nós pela propaganda. ${ }^{107}$
\end{abstract}

Little Caesar nos mostra, entretanto, que a preocupação com a própria imagem não dissolve as lacunas culturais entre as classes sociais. Um bom exemplo se dá na sequência seguinte à prova de roupa, no primeiro e único encontro que Rico tem com o chefe das gangues da cidade. De acordo com Kaminsky, dentro da estrutura das gangues nos filmes de Hollywood,

os chefes permanecem acima da gangue, anônimos, à distância, e no controle. Quando os chefes são revelados, descobrimos que são da "alta sociedade", influentes e ricos. Eles podem ser desocupados ricos (Sydney Blackmer em Little Caesar), banqueiros e oficiais do governo (Bullets or Ballots) ou empresários de classe média de aparência respeitável (Jack Elam em Baby Face Nelson e Fred Clark em White Heat). São esses chefes da classe média e alta, escondidos atrás de um líder de gangue corajoso, que nós aprendemos a odiar nos filmes de gângster. Eles, em meio à Depressão que sabemos existir nos filmes dos anos 1930, estão acumulando riqueza, pegando o que há de dinheiro disponível, vestindo ternos, e vivendo do trabalho de gângsteres ambiciosos que surgiram da classe trabalhadora. Nós vemos o gângster assumir riscos, manter a gangue na linha, proteger sua posição, extorquir tributos de trabalhadores que não possuem o suficiente nem para si próprios, e, por fim, cair de maneira inevitável para ser substituído por outro como ele enquanto os chefes continuam protegidos. Esse padrão se repete a partir de Little Caesar, no qual o Big Boy não é nem preso, nem punido. ${ }^{108}$

De fato, tanto Rico como o espectador só sabem da existência de Big Boy nas referências que se faz ao personagem durante a narrativa, e a presença dele em cena no filme

${ }^{107}$ Jameson, F. Marcas do visível. Rio de Janeiro: Graal, 1995, p. 12.

${ }^{108}$ Kaminsky, S. M. Little Caesar and its Role in the Gangster Film Genre. In: Philadelphia: Journal of Popular Film, Vol. 1, Iss. 3, 1972, p. 220. 
é muito breve, o que reforça a afirmação de que sua posição dentro da hierarquia da gangue e na sociedade são quase inatingíveis para o protagonista.

Assim que entra na residência de Big Boy, Rico admira a arquitetura e a decoração do ambiente, até ver uma pintura na parede, que é mostrada em close enquanto Big Boy pergunta a Rico em voz-over:

Big Boy: Você gosta dela?

Rico: Oh, eu acho elegante.

Big Boy: [em close] Isso me custou quinze mil dólares.

Rico: [em close, demonstrando surpresa] Quinze mi- [olha para fora do enquadramento, na direção do quadro na parede] Cara, essas molduras de ouro devem custar mesmo uma fortuna.

O comportamento individual de Rico na casa de Big Boy é análogo ao que ocorre coletivamente na cena do banquete, na qual nos

\footnotetext{
deparamos com uma simulação paródica de um banquete da alta sociedade. A gangue está vestida de maneira apropriada, mas não tem a menor noção do protocolo ou da linguagem adequadas a uma ocasião como essa. Ninguém consegue fazer um discurso eloquente, o banquete se desintegra em uma guerra de comida, e o presente que a gangue dá a Rico é roubado: aparentemente, aqueles que só conseguem macaquear a "sociedade", no fim das contas, são apenas macacos mesmo. ${ }^{109}$
}

Tanto a cena descrita acima como a do banquete em homenagem a Rico mostram o sentimento de vazio e de falta de sentido que o personagem experimenta conforme tem acesso aos fetiches que a sociedade burguesa lhe oferece em substituição aos seus desejos de classe. Faz parte da emancipação da classe trabalhadora o desejo de estar livre de qualquer necessidade ou restrição - não passar fome, por exemplo. Contudo, quando participa de um banquete, a sociedade burguesa oferece a Rico o consumo de mercadorias como a bebida alcoólica, da qual ele sequer pode tirar proveito porque não gosta de álcool, e a comida em abundância, que termina por ser arremessada pelos seus convidados entre si. O banquete em Little Caesar é uma figuração distorcida da saciedade, e a cena do quadro na casa de Big

${ }^{109}$ Munby, J. Public Enemies, Public Heroes - Screening the Gangster from Little Caesar to Touch of Evil. Chicago: The University of Chicago Press, 1999, p. 48. 
Boy reforça o caráter postiço da subjetividade burguesa assumida pelo protagonista ao longo da narrativa.

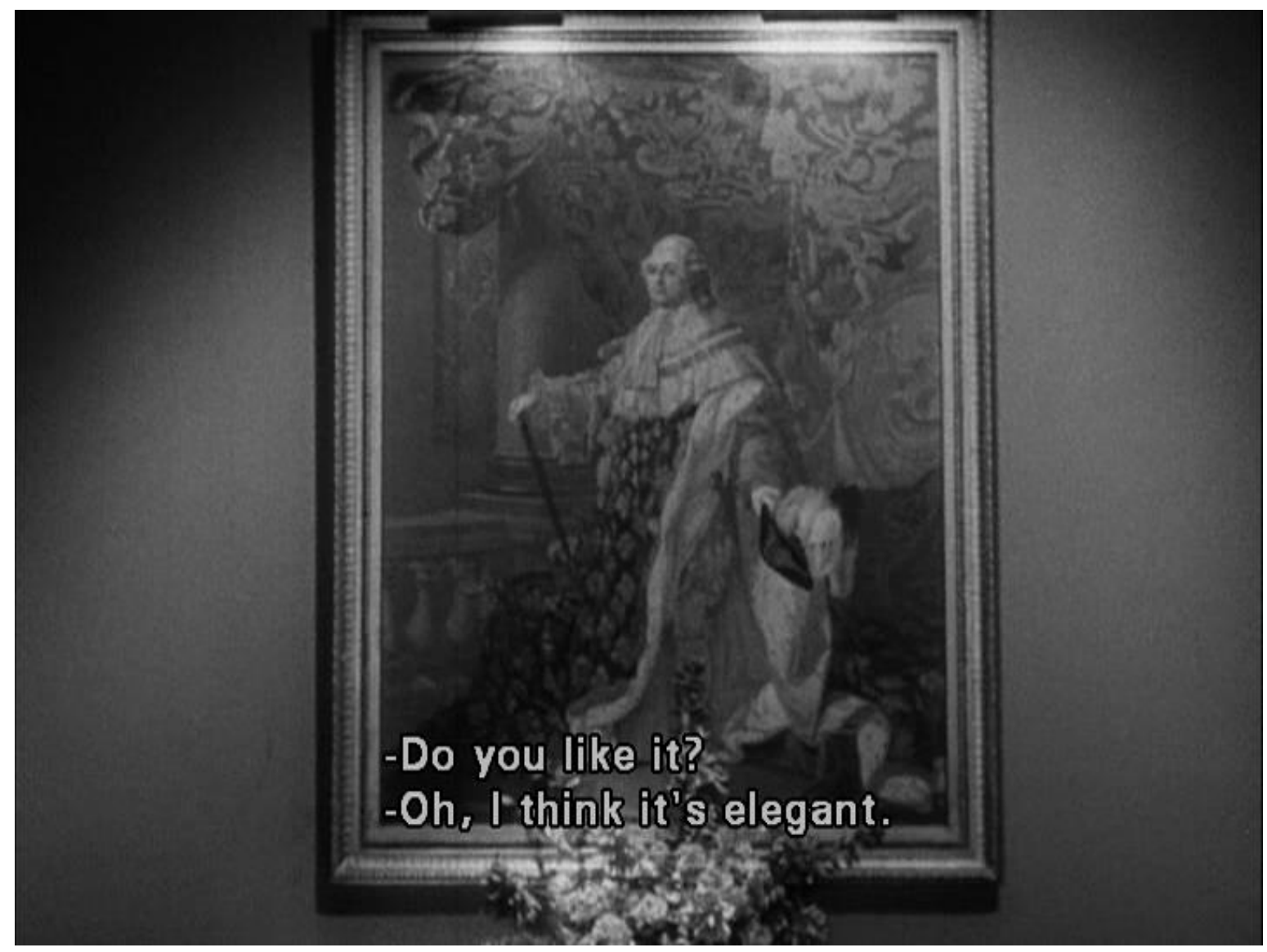

Figura 15 - A pintura na parede da casa de Big Boy.

O filme nos mostra que o gângster pode, por meio do crime organizado, comprar joias e roupas caras, e adquirir a aparência dos membros da alta sociedade; em sua essência, entretanto, o criminoso mantém a cultura de suas origens proletárias, que, dentro do julgamento efetuado pela narrativa, tem menor valor. $\mathrm{O}$ que o encaminhamento dessa questão ao longo da narrativa nos mostra é o estabelecimento de valores absolutos entre os polos, ou seja, a elite - mesmo que erigida ilegalmente - detém não só o poder econômico, mas também o cultural, enquanto Rico é considerado um indivíduo sem cultura. A cena de Rico com Big Boy em Little Caesar nos aponta, simultaneamente, a distância entre as classes sociais e a rigidez da estrutura que mantém essa distância. 


\section{O mito da Máfia}

A sequência seguinte à cena no restaurante no início do filme mostra Rico chegando ao Palermo Club e se apresentando a Sam Vettori, que nesse momento da narrativa ainda é dono do clube e chefe de uma das gangues da cidade. Vettori esclarece a Rico os termos do "contrato" - o chefe centraliza todas as decisões e rumos da gangue; ninguém atira, porque "é coisa do passado"; e o dinheiro é dividido da maneira que Vettori quiser. Rico concorda com tudo e é, então, apresentado ao restante do grupo que está sentado a uma mesa na sala ao lado jogando cartas. A câmera se aproxima em dolly shot e, sem cortes, fecha o plano em cada um dos personagens conforme Vettori os apresenta:

Sam Vettori: Esse é Tony Passa. [a câmera mostra o personagem dormindo em um sofá]. Ele dirige melhor do que qualquer ladrão nessa cidade. [a câmera se movimenta na direção da mesa] Otero. Ele é pequeno, mas é muito bom. Bat Carilla. Killer Peppi. Kid Bean. E esse aqui é Scabby. Um cara muito esperto. [chamando a atenção de todos] Rapazes! Vamos, Tony, acorde! Quero que vocês conheçam um novo integrante do nosso grupo. Esse é...

Rico: Caesar Enrico Bandello.

Sam Vettori: Little Caesar, é?

Rico: É, isso mesmo.

Destacamos da sequência que mostra a introdução de Rico à gangue dois elementos importantes: em primeiro lugar, o movimento de câmera utilizado; e em segundo lugar, a ascendência italiana da maioria dos integrantes da gangue. Discorreremos sobre esses dois pontos a seguir.

Sobre o movimento de câmera dessa sequência, é possível observar que não se trata de uma câmera subjetiva per se, pois Rico permanece fixo em seu lugar, enquanto a câmera se desloca no espaço e se aproxima dos outros personagens; a escolha dos planos e o arranjo cenográfico mostram Rico como um outsider na gangue. Antes do dolly shot, por exemplo, Rico e Vettori são filmados em primeiro plano, de costas para a câmera, na penumbra, enquanto a mesa onde os integrantes da gangue jogam cartas ocupa o centro do enquadramento, focado ao fundo. A mesa circular e a iluminação da cena mostram um grupo fechado, sem espaço para novos membros. O único que não está sentado à mesa nessa sequência é Tony, justamente o primeiro a tentar sair da gangue. 


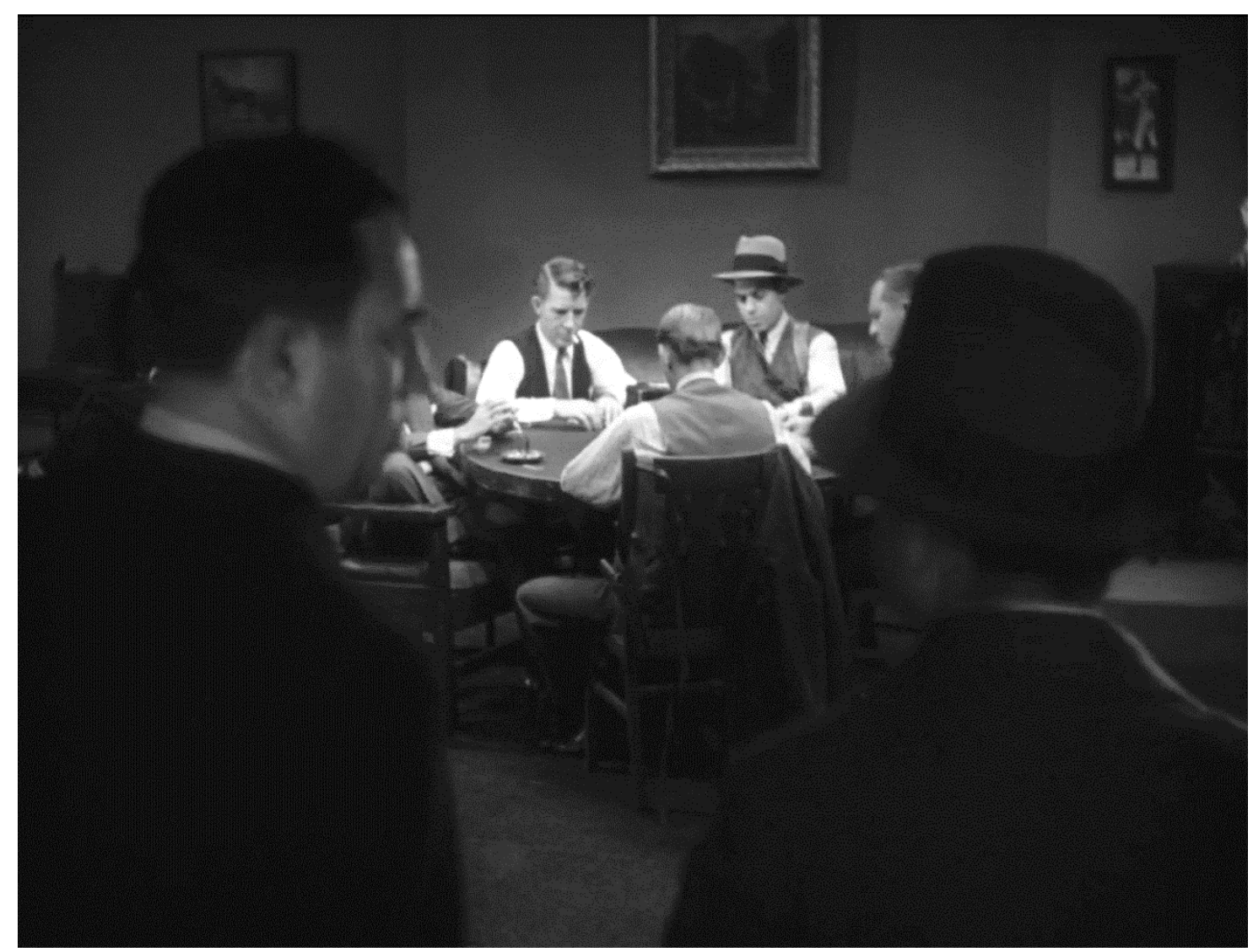

Figura 16 - Rico sendo apresentado para a gangue por Sam Vettori

A questão do modus operandi da gangue de Rico também merece ser levada em consideração em nossa análise, pois vai na contramão do que se praticava em termos de crime organizado naquele momento nos EUA. Embora a narrativa esteja situada em plena Lei Seca (1920-1933), Little Caesar não aborda diretamente o assunto da produção, distribuição e comércio ilegal de bebidas, que constituiu a principal atividade econômica do crime organizado naquele período histórico, e que foi tema das narrativas de gângster hollywoodianas subsequentes, como Public Enemy e Scarface,

O contrabando de bebida alcoólica no período da Lei Seca representou um avanço significativo nos negócios do crime organizado nos EUA, pois era uma atividade que combinava o oferecimento de um produto ilegal cuja demanda era elevada com a fraca fiscalização da polícia, que era facilmente subornada pelas gangues. O cenário era, dessa forma, como um investimento em renda fixa, com elevada liquidez e baixo risco. Os negócios da gangue de Rico, no entanto, iam contra essa lógica de mercado, pois se concentravam nos assaltos à mão armada a clubes e bares - o equivalente a investimentos 
em renda variável, no qual o investidor abre mão da segurança em nome da possibilidade de ganhos maiores em menos tempo.

O segundo ponto na sequência de apresentação de Rico é a ascendência imigrante dos membros da gangue. Tanto o protagonista como seus companheiros de gangue têm, em sua maioria, sobrenomes italianos, incluindo o chefe da quadrilha (Vettori) e Joe Massara, parceiro de Rico no início do filme. Se por um lado o fato de o cinema falado ter dado voz aos imigrantes é um aspecto positivo, por outro lado não há como negar que Little Caesar reforça o mito sobre as organizações criminais compostas por imigrantes italianos.

A criminalização dos imigrantes no cinema tem raízes, segundo David Ruth, nos estudos publicados por eugenistas desde o fim do século XIX, e que receberam atenção da imprensa até meados da década de 1920. De acordo com esses cientistas, uma ampla gama de problemas da sociedade - da criminalidade à pobreza, passando pela promiscuidade sexual - eram consequência da "criação" de "seres defeituosos". "O criminoso é um indivíduo único e altamente diferenciado, que nitidamente se desvia da norma" ${ }^{110}$. Esse discurso eugenista foi ampliado até incorporar diferenças étnicas:

\footnotetext{
Muitos eugenistas apontaram para a criminalidade como uma razão para fechar as portas aos imigrantes. Edwin Grant Conklin, colaborador da Scribner's [periódico publicado entre o fim do século XIX e início do século XX], era um entre muitos a relacionar "raças estrangeiras" a "formas peculiares de crime e ilegalidade": irlandeses tornavam-se criminosos através do alcoolismo devido a uma inerente “organização nervosa instável”; italianos, com sua "disposição emocional altamente excitável", eram mestres no sequestro, extorsão e crimes violentos; russos e poloneses, em "crimes lucrativos, como o roubo, pequenos furtos, e receptação de mercadoria contrabandeada; judeus, na escravidão branca e prostituição. ${ }^{111}$
}

Outro fator apontado pelos eugenistas da época para a criminalidade estava relacionado a questões sociais. Segundo eles, havia uma "classe criminosa", que se reproduzia geração após geração, e produzia novos criminosos:

A retórica de classe era frequentemente adicionada ao nativismo com o respaldo da ciência. "Nós estamos recebendo grandes quantidades de pessoas com baixa

\footnotetext{
${ }^{110}$ Ruth, D. Inventing the public enemy: the gangster in American culture, 1914-1934. Chicago: The University of Chicago Press, 1996, p. 13.

${ }^{111}$ Ibidem, p. 13-14.
} 
inteligência", escreveu Conklin, "e é essa classe que constitui o maior perigo biológico... Qualquer medida que prevenisse o crescimento dessa classe de pessoas com baixa inteligência reduziria a imensa quantidade de crimes e ilegalidades nesse país". Avisos sobre o rápido crescimento dessa classe anômala refletiam os temores de americanos nativos de que a sociedade respeitável seria ultrapassada pelo rápido crescimento da classe trabalhadora. "Essa classe de defeituosos... da qual praticamente todos os criminosos saem”, como um eugenista alertou, "está dando à sociedade americana cinco filhos para cada contribuição da classe mais inteligente". A sociedade decente estava sob o cerco da perigosa classe baixa, e o criminoso era exemplo dessa ameaça. ${ }^{112}$

Além da xenofobia com respaldo científico, os imigrantes italianos também sofreram com o mito da "máfia italiana", que ocupa o imaginário cultural norte-americano desde o início do século XX. Segundo Hobsbawm, as máfias surgiram na Itália pré-capitalista (mais precisamente nas regiões da Sicília e Calábria) durante o domínio dos estados bourbônico ou piemontês no século XIX como uma "máquina paralela de leis e poder organizado" que

representava para o cidadão nas áreas sob sua influência a única lei e poder eficientes. (...) Não foi, porém, universal, pois nem todas as camadas da sociedade siciliana tinham a mesma necessidade dele. Os pescadores e marinheiros, por exemplo, nunca desenvolveram o código de omertà e, à parte o submundo, ele nunca foi forte nas cidades, isto é, nas verdadeiras cidades e não nas grandes aglomerações onde camponeses sicilianos viviam no meio de uma região vazia, infestada de bandidos ou mesmo de malária". ${ }^{113}$

Por ser em sua origem um fenômeno essencialmente rural, "é difícil ver como a Máfia poderia ter uma centralização hierárquica, levando-se em conta o que eram as comunicações no século XIX"114. Dessa forma, segundo Debord, "a máfia não passava de um arcaísmo transplantado, quando começou a se manifestar no início do século nos Estados Unidos, com a imigração de trabalhadores sicilianos"115; o caráter a priori criminoso da Máfia e sua organização se desenvolveram plenamente nos EUA do fim do século XIX, com a concentração dos imigrantes italianos em algumas poucas grandes cidades. Ainda assim, segundo o historiador Michael Woodiwiss, as atividades da Máfia italiana nunca foram tão

${ }^{112}$ Ruth, D. Inventing the public enemy: the gangster in American culture, 1914-1934. Chicago: The University of Chicago Press, 1996, p. 14.

${ }^{113}$ Hobsbawm, E. Rebeldes Primitivos - Estudos sobre formas arcaicas de movimentos sociais nos séculos XIX e XX. Rio de Janeiro: Zahar Editores, 1978, p. 43.

114 Ibidem, p. 41.

${ }^{115}$ Debord, G. A sociedade do espetáculo. Rio de Janeiro: Contraponto, 1997, p. 218. 
amplas como se imagina a ponto de justificarem o estereótipo que se criou em torno desses imigrantes.

\begin{abstract}
Embora a Máfia tenha confirmado sua posição como força dominante no submundo americano até o fim da década de 1920, ela nunca estabeleceu um monopólio do contrabando de bebidas alcoólicas. O mercado era muito vasto, e a organização e o capital necessários grandes demais para serem controlados por um grupo tão restrito e etnocêntrico como a Máfia Siciliana. ${ }^{116}$
\end{abstract}

A afirmação de Woodiwiss acima nos leva de volta à questão da relação simbiótica entre o crime e o sistema produtivo. No caso do período da Lei Seca norte-americana, podemos citar como exemplo dessa relação a produção legal de bebidas no Canadá e a sua distribuição ilegal pela fronteira com os EUA - a mesma rota comercial era utilizada para o contrabando de vinho francês e whisky escocês. A partir de 1926, foram exportados para os EUA cerca de 3.000.000 de litros de bebida alcóolica por ano, e mais de US\$ 31,000.000 somente no ano de 1927. ${ }^{117}$ Os dados nos mostram que o comércio de bebidas alcóolicas dentro dos EUA não poderia ser feito sem a colaboração da indústria.

Segundo o historiador Michael Woodiwiss, a primeira vez que o termo "Máfia" foi utilizado nos EUA para denominar uma organização criminal formada por imigrantes italianos ocorreu após a morte do chefe de polícia de Nova Orleans David Hennessy em 15 de outubro de 1890, que investigava a disputa pelo domínio do comércio de frutas entre grupos de comerciantes do sul da Itália e da Sicília. Hennessy, em seu leito de morte, acusou os italianos de terem atirado nele. Os jornais e revistas da época acusaram a Máfia, "uma sociedade secreta, de origem siciliana, baseada em juramentos e que usava assassinatos para manter a disciplina”. Embora não houvesse qualquer prova concreta do crime, nove imigrantes italianos foram presos. Após um julgamento cheio de inconsistências e contradições, o júri decidiu absolver seis dos réus e não se chegou a um acordo sobre os três restantes. A população da cidade resolveu, então, fazer justiça com as próprias mãos: centenas de pessoas invadiram a prisão e tiraram os réus do "caso Hennessy" à força. No total, onze italianos foram linchados até a morte, sendo que quatro deles sequer eram réus

\footnotetext{
${ }^{116}$ Woodiwiss, M. Organized Crime and American Power. Toronto: University of Toronto Press, 2001, p. 33.

${ }^{117}$ Cf. Kyvig, D. E., Jeffers, H. F. Repealing National Prohibition. Kent: Kent State University Press, 2000, p. 107.
} 
nesse julgamento - apenas tiveram o azar de serem italianos e estarem no lugar e hora errados. Nenhum dos linchadores foi levado a julgamento. ${ }^{118}$

A repercussão do "caso Hennessy" ajudou a estabelecer o "mito da Máfia" no imaginário norte-americano, alimentado principalmente pela indústria cultural primeiramente na figura da imprensa, da literatura e, posteriormente, do cinema, dentro do qual Little Caesar tem papel central por ser um dos precursores dos filmes falados a colocar o imigrante italiano como protagonista. Para Jameson, o "mito da Máfia" cumpre uma função ideológica

enquanto substituição do grande negócio pelo crime, como deslocamento estratégico de toda a ira gerada pelo sistema americano, nessa imagem especular do grande negócio fornecida pela tela de cinema e pelas várias séries de TV. (...) a função da narrativa mafiosa é estimular a convicção de que a deterioração da vida cotidiana nos Estados Unidos de hoje é uma questão ética, mais do que econômica, relacionada não com o lucro, mas "meramente” com a desonestidade, e com certa corrupção moral onipresente cuja fonte mítica última remonta ao puro Mal dos próprios mafiosos. (...) o mito da máfia coloca estrategicamente a visão daquilo que aparece como uma aberração criminosa desviante da norma, e não como a própria norma; na verdade, a substituição da análise política e histórica pelas considerações e julgamentos éticos é geralmente o indício de uma manobra ideológica e do intento de mistificar. As fitas sobre a Máfia projetam, assim, uma “solução" para as contradições sociais - incorruptibilidade, honestidade, combate ao crime e, finalmente, as próprias lei e ordem -, que é evidentemente uma proposição muito diferente daquele diagnóstico da miséria americana, cuja prescrição seria a revolução social. ${ }^{119}$

$\mathrm{Na}$ avaliação de Jameson, a violência do sistema econômico causa uma reação violenta, e o filme de gângster cumpre, por meio da indústria cultural, a função de oferecer ao público um objeto para ele descarregar essa violência. Dessa forma, o problema da "deterioração da vida cotidiana" norte-americana é deslocado para a Máfia, e o gângster se torna, por uma questão ética, alvo de uma raiva pública que deveria ser direcionada a bancos e negócios que mergulharam os EUA na recessão durante a década de 1930.

\footnotetext{
${ }^{118}$ Cf. Kyvig, D. E., Jeffers, H. F. Repealing National Prohibition. Kent: Kent State University Press, 2000, p. 97-99.

${ }^{119}$ Jameson, F. Marcas do Visível. Rio de Janeiro: Graal, 1995, p. 32-33. Grifo nosso.
} 
Em Little Caesar, por exemplo, Rico é caracterizado com um indivíduo que rouba, mata, faz ameaças, pratica extorsões e, além de tudo, tenta interromper o romance entre Joe e Olga. Tais ações impedem que o protagonista crie uma adesão emocional com o público. A caracterização de Rico, entretanto, não é livre de ambiguidades, pois, ao mesmo tempo em que aprende a direcionar sua violência para o gângster, o espectador de Little Caesar também percebe, logo na primeira cena do filme, que a motivação para as ações criminosas e antiéticas do protagonista vem do receituário da ideologia do self-made man norteamericano, como a livre iniciativa, o empreendedorismo, o acúmulo de capital, e o desejo de reconhecimento público do sucesso conquistado - características todas muito caras aos verdadeiros responsáveis pela Depressão.

Esse aspecto da narrativa abre um precedente para o questionamento sobre os limites entre o mundo dos negócios e o crime organizado, e o público apreende que Rico não é, como Jameson diz, "uma aberração criminosa desviante da norma”, mas, sim, "a própria norma". Tal constatação permite ao espectador mais atento deixar de lado as "considerações e julgamentos éticos", e se aproximar de uma análise "política e histórica" por meio do estabelecimento de homologias estruturais entre o crime organizado, o mundo dos negócios e o enredo do filme. Sob tal perspectiva, a análise das ações de Rico nos mostra que ele está muito mais próximo da individualidade burguesa do que da luta coletiva ao lado de seus irmãos de classe. Dessa forma, embora o protagonista seja um personagem caracterizado como tipo social e tenha origens na classe trabalhadora, Rico não é capaz de sintetizar na sua figura individual nem os anseios, nem as tarefas, nem as características da classe como um todo, ou mesmo de parte dela. Ele é simplesmente um indivíduo cujos delírios pequenoburgueses estão muito aquém do desejo de emancipação da classe trabalhadora na sua totalidade. 


\section{Capítulo 2 - Force of Evil}

Não há nenhum mal que o homem tenha criado, desta ou de qualquer outra espécie, contra o qual outros homens não tenham lutado para pôr um fim.

Raymond Williams ${ }^{120}$

Baseado no romance Tucker's People, de Ira Wolfert, Force of Evil ${ }^{121}$ (1948) é o primeiro trabalho de Abraham Polonsky como diretor. O filme tem como protagonista o ator John Garfield no papel de Joe Morse, um advogado ambicioso que trabalha para Ben Tucker (Roy Roberts) em Wall Street. Tucker é um gângster, ex-traficante de bebida durante a Lei Seca, que quer dominar o mercado de jogos de azar de Nova Iorque. Tal monopólio, no entanto, afeta diretamente os negócios de Leo (Thomas Gomez), irmão de Joe, que sofre de problemas cardíacos e opera uma pequena banca ${ }^{122}$ de apostas na cidade. Dessa maneira, Joe procura alternativas para atingir as metas estabelecidas por seu chefe e, ao mesmo tempo, tenta salvar seu irmão da bancarrota.

De acordo com o crítico cultural Michael Denning, tanto Polonsky como Garfield faziam parte de uma geração de artistas e intelectuais na década de 1940 oriundos de famílias de imigrantes da classe trabalhadora norte-americana. Tal geração, denominada por Denning como plebeians, via no desenvolvimento do aparato da indústria cultual uma oportunidade de ganhar a vida como escritores ou artistas, deixando para trás o mundo do trabalho braçal dos pais ao ingressar em um universo próximo ao do trabalho intelectual - aparentemente de classe média, mas com pouca garantia de emprego. ${ }^{123}$

Os plebeians, por sua vez, constituíam uma parcela da "Frente Cultural" (Cultural Front), um movimento cultural e político que se desenvolveu a partir do legado da Depressão vivida pelo país nos anos 1930. Denning ressalta que o surgimento da "Frente Cultural” está

\footnotetext{
${ }^{120}$ Williams, R. Tragédia Moderna. São Paulo: Cosac Naify, 2002, p. 56-57.

${ }^{121}$ Force of Evil é conhecido no Brasil por dois títulos distintos: "Força do Mal" e "Força Diabólica". Esse último, por sua vez, é homônimo do título em português de The Tingler (William Castle, 1959). A fim de evitarmos qualquer ambiguidade, utilizaremos o título original em inglês para nos referirmos à obra de Abraham Polonsky.

$122 \mathrm{O}$ termo em inglês (bank) utilizado no filme para o local onde se controlam as apostas do jogo é o mesmo que define "estabelecimentos ou sociedades mercantis de crédito", e Polonsky faz uso dessa polissemia de forma produtiva ao longo da narrativa. Para o nosso trabalho, entretanto, adotaremos o termo "banca", mais comum no português brasileiro quando relacionado a jogos de azar.

${ }^{123}$ Cf. Denning, M. The Cultural Front: The Laboring of American Culture in the American Century. New York: Verso, 1996, p. 60-61.
} 
ligado a três fatores principais. Pelo fato de serem filhos de imigrantes da classe trabalhadora, muitos dos trabalhadores da indústria cultural traziam para esse meio os valores passados por seus pais. Além disso, boa parte dos integrantes da Frente Cultural iniciou seu aprendizado na década de 1930, num período em que o conflito de classes se intensificou. Por último, no caso de Hollywood, muitos dos trabalhadores adquiriram uma determinada consciência de classe nesse período, visto que diretores, atores e roteiristas sofriam represálias por parte dos estúdios ao tentarem se organizar em sindicatos.

As biografias de Polonsky e Garfield ilustram bem como a atmosfera de luta política na formação dos artistas dessa geração teve ressonância nas obras que foram produzidas na década de 1940. Abraham Lincoln Polonsky nasceu em 5 de dezembro de 1910 no Lower East Side de Nova Iorque como o primogênito de uma família de imigrantes judeus russos. Durante sua juventude, foi influenciado pelos ideais socialistas do seu pai, um farmacêutico formado na Universidade de Columbia. Em 1935, Polonsky formou-se em direito pela Columbia Law School, e em 1937 abandonou seu emprego como advogado para dedicar-se ao ofício de escritor. Antes de iniciar sua carreira em Hollywood, produziu scripts para programas de rádio, ensaios e romances. Seu interesse nas questões sindicais o levaram a criar e editar, de 1939 a 1941, um jornal de esquerda chamado The Home Front, e em 1943 publicou o romance The Enemy Sea, dedicado à National Maritime Union. Entre seus colegas roteiristas, Polonsky foi um dos poucos a chegar em Hollywood com experiência no Partido Comunista (ao qual filiou-se em 1936) e com profundo conhecimento da teoria marxista. ${ }^{124}$ Polonsky gostava de dizer que ele não fazia filmes Marxistas, mas, como Marxista, ele fazia filmes da única maneira que fazia sentido. ${ }^{125}$

Durante a Segunda Guerra Mundial, Polonsky trabalhou para o Office of Strategic Services - precursor do que conhecemos hoje como a CIA - e, apesar de já ter recebido convites de estúdios de cinema antes de ir para a Guerra, Hollywood "não [lhe] atraía como um lugar para viver e trabalhar". Foi somente com o fim da Guerra que ele assinou um contrato com a Paramount, buscando segurança financeira para si e para sua família. Seu primeiro trabalho foi como co-roteirista da comédia romântica Golden Earrings (Mitchell Leisen, 1947), estrelada por Marlene Dietrich. Entretanto, a história de Polonsky em

${ }^{124}$ Cf. Ceplair, L., Englund, S. The Inquisition in Hollywood: Politics in the Film Community, 1930-1960. Oakland: University of California Press, 1983, p. 191-194; Buhle, P., Wagner, D. A very dangerous citizen: Abraham Polonsky and the Hollywood Left. Berkeley and Los Angeles: University of California Press, 2001.

${ }^{125}$ Buhle, P., Wagner, D., op. cit., p. 95. 
Hollywood se inicia de fato, segundo Paul Buhle e Dave Wagner, com o convite para trabalhar na Enterprise Studios, uma produtora independente que tinha a proposta de oferecer aos atores e diretores parte dos lucros. ${ }^{126}$ Tal proposta atraiu outros nomes de destaque da esquerda hollywoodiana, como o diretor Robert Rossen e o ator John Garfield, com quem Polonsky trabalhou em seus dois grandes sucessos no período pré-macarthismo: Body and Soul (1947), como roteirista, e Force of Evil (1948), como diretor. No auge de sua carreira em Hollywood, Polonsky foi incluso na "lista negra" (blacklist) de Hollywood em 1951, ao se recusar a nomear membros do Partido Comunista perante o House Committee on UnAmerican Activities (HUAC), que investigava a participação de comunistas na indústria cinematográfica:

\footnotetext{
Começando por uma série de depoimentos ao HUAC no fim da década de 1940, Hollywood foi identificada como um grande paraíso para comunistas e simpatizantes do comunismo, menos porque a acusação era verdadeira do que devido ao seu sensacionalismo e à publicidade que ela trouxe à causa anticomunista. Além disso, Hollywood teve alguns dos sindicatos mais progressistas da América, e a tentativa de ligar o ativismo trabalhista de Hollywood ao comunismo era parte de um esforço mais amplo nos anos 1940 e 1950 de reverter os avanços feitos pelo sindicalismo nos anos $1930 .^{127}$
}

Após um período de autoexílio na França, onde se dedicou a escrever um de seus romances, o diretor retornou a Nova Iorque para trabalhar como roteirista de televisão sob pseudônimos, ou utilizando fronts, como eram conhecidos artistas que cediam seus nomes para publicar obras de colegas que estavam na "lista negra". Apesar de permanecer no submundo artístico, Polonsky diz ter conseguido se manter razoavelmente bem financeiramente durante esse período, pois a demanda por trabalho era grande. Contudo, ele voltou a ter seu nome creditado em uma produção de Hollywood somente em 1969, como roteirista de Madigan, dirigido por Don Siegel, pouco tempo depois de sua obra ter sido descoberta por críticos ingleses e franceses. Ele ainda trabalhou para a televisão e o cinema até a década de 1980, e faleceu em 26 de outubro de $1999 .{ }^{128}$

\footnotetext{
${ }^{126}$ Cf. Munby, J. Public Enemies, Public Heroes - Screening the Gangster from Little Caesar to Touch of Evil. Chicago: The University of Chicago Press, 1999, p. 124.

${ }^{127}$ Booker, M. K. From box office to ballot box: the American political film. Westport: Prager Publishers, 2008 , p. 65.

${ }^{128}$ Buhle, P., Wagner, D. A very dangerous citizen: Abraham Polonsky and the Hollywood Left. Berkeley and Los Angeles: University of California Press, 2001.
} 
John Garfield, por sua vez, não teve vida tão longeva. Também de ascendência judia, Garfield nasceu em 1913 no mesmo bairro em que Polonsky cresceu, o Lower East Side de Nova Iorque. O início de sua formação como ator coincidiu com a crise de 1929 e a Depressão na década de 1930, e esses eventos moldaram a consciência política de Garfield. Sua carreira profissional teve início com a peça Counselor-at-Law, de Elmer Rice, cujo protagonista era interpretado por Paul Muni, que anos mais tarde interpretaria o gângster Toni Camonte, de Scarface, (Howard Hawks, em 1932). ${ }^{129}$

Em 1935, Garfield se junta ao Group Theatre, que teve um papel importante no teatro de esquerda americana e reuniu artistas como Elia Kazan, Clifford Odets, Marc Blitzstein, entre outros. A atuação de Garfield em Awake and Sing, de Odets, rendeu-lhe elogios da crítica e a atenção da Warner Bros., que o levou para Hollywood em 1938. Garfield atuou em vinte e cinco filmes produzidos pelos estúdios dos irmãos Warner até 1946, mas as divergências entre o ator e os produtores da Warner levaram a um desgaste dessa relação, uma vez que Garfield desejava ter autonomia para escolher os papeis que realçassem sua versatilidade como ator, enquanto o estúdio não abria mão do controle sobre quais filmes Garfield atuaria ou não. Tal impasse fez o ator, após o fim do contrato com a Warner, juntarse ao produtor David L. Loew na recém-fundada Enterprise Studios, onde poderia ter controle sobre seus próprios projetos. Body and Soul (Robert Rossen, 1947) foi o primeiro e único sucesso de bilheterias da Enterprise Studios, tendo Garfield como protagonista. O filme também foi o primeiro trabalho de Garfield com Abraham Polonsky, autor do roteiro. Body and Soul rendeu à dupla indicações ao Oscar de melhor ator e de melhor roteiro original. No ano seguinte, a parceria se repetiu em Force of Evil, dessa vez com Polonsky no roteiro e direção. ${ }^{130}$

Embora não fosse tão ativo politicamente fora das telas como outros artistas em Hollywood, Garfield considerava-se um liberal e fazia questão de assinar petições e apoiar movimentos, como o Committee for the First Amendment, em 1947, que lutava pelo direito à liberdade de expressão dos artistas hollywoodianos ameaçado pelas ações do HUAC. As investigações do comitê anticomunista ligaram o nome de John Garfield a "organizações subversivas" e, em março de 1951, Garfield foi intimado a prestar esclarecimentos sobre suas atividades ao comitê. $\mathrm{O}$ ator negou qualquer envolvimento com o Partido Comunista e

\footnotetext{
${ }^{129}$ Maland, C. Film Gris: Crime, Critique, and Cold War Culture in 1951. In: Film Criticism, vol. 26, no. 3, 2002 , p. 5.

${ }^{130}$ Idem.
} 
declarou não conhecer nenhum membro do partido entre seus colegas em Hollywood. Suas declarações deixaram insatisfeitos tanto os membros do comitê - pois Garfield não denunciou qualquer nome em seu depoimento - quanto seus colegas de esquerda - que o acusaram de se acovardar em seu testemunho. O ator foi incluído na "lista negra" de Hollywood, e nenhum estúdio quis mais escalá-lo para qualquer tipo de filme. Em 1952, Garfield faleceu aos 39 anos de idade, vítima de complicações cardíacas. ${ }^{131} \mathrm{Na}$ introdução ao livro The Films of John Garfield, de Howard Gelman, Polonsky diz que "o Group [Theatre] o treinou, os filmes o formaram, e a lista negra o matou"132.

As biografias de Garfield e Polonsky nos indicam que Force of Evil é resultado do esforço conjunto de artistas progressistas. Há, entretanto, outros fatores envolvidos no contexto de produção do filme que devem ser levados em consideração. A própria ascendência judia de ambos os artistas é uma delas. A influência que trabalhadores judeus tiveram na cultura popular norte-americana é imensa em diversos campos: eles contribuíram para a evolução do jazz, dedicaram seus talentos a artes obscuras como as histórias em quadrinhos, publicaram diversos romances best-sellers, e dominavam os sets da Broadway. Contudo, foi a reunião de atores, roteiristas, diretores, cenógrafos na indústria cinematográfica que potencializou a reprodutibilidade do ponto de vista desses trabalhadores no meio artístico. ${ }^{133}$ No caso específico da cooperação entre Polonsky e Garfield, Buhle e Wagner apontam que

os dois tinham uma relação próxima e intuitiva, em grande parte devido à sensibilidade de Polonsky ao fato de que "Garfield se sentia inadequado como um intelectual". Polonsky tentou convencer Garfield de que estava errado, porque “não há conexão genética entre ser um intelectual e ser um artista, não mais do que ser um artista e ter bom caráter”. (...) A importância de Garfield, mais do que em seu brilho como ator, estava em sua presença como "uma estrela que representava um fenômeno social... sem contradições na imaginação daqueles que o amavam por se identificarem com ele", numa época em que os "judeus pobres que não entraram no sistema financeiro gravitavam em torno do socialismo... rebeldia... e autoconsciência, severa ou neurótica”. Alguns se tornaram gângsteres; muitos se tornaram gângsteres de terno de flanela cinza; mas outros permaneceram

\footnotetext{
${ }^{131}$ Maland, C. Film Gris: Crime, Critique, and Cold War Culture in 1951. In: Film Criticism. Vol. 26, no. 3, 2002, p. 5 .

${ }^{132}$ Polonsky, A. On John Garfield. In: Polonsky, A. Abraham Polonsky: interviews / edited by Andrew Dickos. Jackson: University of Mississippi Press, 2013, p. 151.

${ }^{133}$ Buhle, P., Wagner, D. A very dangerous citizen: Abraham Polonsky and the Hollywood Left. Berkeley and Los Angeles: University of California Press, 2001, p. 130.
} 
o que sempre foram por toda vida, homens e mulheres da vizinhança que continuaram a acreditar que algo melhor do que uma sociedade violenta ainda era possível, senão inevitável. ${ }^{134}$

Outro fator que vale a pena ressaltar é o cenário econômico da Hollywood pós-guerra. De acordo com o historiador Charles Maland, apesar do crescimento das hostilidades à liberdade de expressão da esquerda no período pós-Segunda Guerra Mundial, alguns diretores e roteiristas em Hollywood foram capazes de produzir filmes com forma e conteúdo progressistas no fim da década de 1940 e início da década de 1950. Embora o senso comum sugerisse que após a condenação dos Hollywood Ten ${ }^{135}$ em 1947 fosse impossível que artistas de esquerda conseguissem trabalho, na prática não foi o que ocorreu. ${ }^{136}$

Do ponto de vista dos roteiristas, a década de 1940 foi uma época de ouro, até o início da "lista negra". Uma maioria considerável de créditos de filmes que foram atribuídas a futuras vítimas da lista (bem como testemunhas amigáveis) datam dessa década e, para os obscuros ou sortudos, aos dois primeiros anos da década de 1950. Havia muita oferta de trabalho e, para os roteiristas mais conhecidos e produtivos, os pagamentos eram bons. ${ }^{137}$

Ainda que o ambiente político fosse desfavorável ao desenvolvimento do trabalho de cineastas de esquerda, o cenário econômico permitiu que esses artistas tivessem emprego, ao menos até 1951, quando a segunda leva de investigações do HUAC teve início. Uma das causas desse cenário favorável foi o crescimento do mercado de produtoras independentes em Hollywood após a Segunda Guerra Mundial. De acordo com o historiador Thomas Schatz, nesse período os independentes tiveram muito sucesso, uma vez que as condições de produção eram favoráveis aos seus interesses e eles gozavam de uma autonomia comercial e criativa sem precedentes. ${ }^{138}$

Não apenas a esquerda de Hollywood, mas diretores com ideais independentes, produtores e estrelas viam uma chance de romper com o domínio dos estúdios no

\footnotetext{
${ }^{134}$ Buhle, P., Wagner, D. A very dangerous citizen: Abraham Polonsky and the Hollywood Left. Berkeley and Los Angeles: University of California Press, 2001, p. 131.

135 Título dado aos dez artistas inclusos na "lista negra" de Hollywood após a primeira leva de depoimentos perante o HUAC, em outubro de 1947. (Cf. Dick, B. Radical Innocence: A Critical Study of the Hollywood Ten. Lexington: University Press of Kentucky, 2009, p. 1)

${ }^{136}$ CF. Maland, C. Film Gris: Crime, Critique, and Cold War Culture in 1951. In: Film Criticism, vol. 26, no. 3, 2002, p. 7.

${ }^{137}$ Buhle, P., Wagner, D., op. cit., p. 82.

${ }^{138}$ Cf. Maland, C., op. cit., p. 8.
} 
fim da década de 1940. Em termos marxistas mais primitivos, isso poderia ser descrito como uma tentativa de tomada de posse dos meios de produção, mas apenas os mais literais ou visionários tomaram a ideia a sério. O que os insurgentes realmente queriam era abandonar os meios de produção existentes e produzir de maneira independente, com distribuição dos grandes estúdios quando fosse necessário ou desejável. ${ }^{139}$

Ao fim de 1947, Hollywood registrava o maior número de produções independentes visto na história do cinema. ${ }^{140}$ Outro fator determinante para essa equação propícia ao desenvolvimento do cinema independente foi a decisão da Suprema Corte, em 1948, contra a propriedade de cadeias de salas de cinema por parte dos estúdios, o que reforçou o incentivo aos produtores independentes. Entretanto, as baixas performances nas bilheterias e a diminuição do público nas salas de cinema de modo geral no fim da década de 1940 limitaram o ímpeto dos filmes de baixo orçamento; as novas companhias, que tantas esperanças tinham de provocar certo impacto no cenário hollywoodiano, acabaram por sucumbir diante da perseguição política no período do macarthismo, que eliminou de Hollywood os cineastas mais controversos e interessantes, entre eles, Polonsky. ${ }^{141}$

As condições de produção de Force of Evil combinavam, dessa maneira, a constante ameaça de perseguição política com uma liberdade criativa poucas vezes vista em Hollywood. Diante desse cenário, o filme se encaixa na filmografia de Polonsky como sua última chance para dar forma ao conteúdo sócio-histórico que se colocava diante dos trabalhadores de Hollywood antes da convocação certa para que ele e seus colegas prestassem depoimentos ao HUAC. Para o roteiro de Force of Evil, Polonsky justifica da seguinte maneira sua escolha pelo romance Tucker's People, de Ira Wolfert:

Eu conhecia Tucker's People. Ele tinha uma alegoria, verdadeira naquele momento, e cruelmente ainda mais apta para os dias de hoje; um ambiente social e personagens familiares para mim; uma sugestão de linguagem do inconsciente que eu poderia usar como diálogo.

A adaptação do romance de Ira Wolfert para o cinema teve mudanças mais radicais na narrativa do que, por exemplo, o que ocorreu na transposição de Little Caesar, de W. R.

\footnotetext{
${ }^{139}$ Buhle, P., Wagner, D. A very dangerous citizen: Abraham Polonsky and the Hollywood Left. Berkeley and Los Angeles: University of California Press, 2001, p. 8.

${ }^{140}$ Maland, C. Film Gris: Crime, Critique, and Cold War Culture in 1951. In: Film Criticism, vol. 26, no. 3, 2002 , p. 8.

${ }^{141}$ Cf. Buhle, P., Wagner, D., op. cit., p. 8.
} 
Burnett, para o cinema. Wolfert e Polonsky trabalharam juntos e eliminaram alguns personagens, combinaram características e ações de dois personagens em um só, entre outras mudanças. O essencial, entretanto, foi mantido: Polonsky roteirizou e dirigiu um filme de gângster em que o crime organizado é alegoria dos negócios ditos legais. O modo como o tema é tratado, entretanto, difere em diversos pontos da narrativa de gângster como a conhecemos em Little Caesar, The Public Enemy e Scarface. Segundo Buhle e Wagner,

\begin{abstract}
[n]aquele momento, nem mesmo os críticos favoráveis sabiam o que pensar sobre Force of Evil. Bosley Crowther, do The Times, avaliou-o como um "drama dinâmico de crime-e-castigo, brilhantemente executado", revelando "um novo talento para a mídia, assim como uma borbulhante obra de arte". No entanto, as implicações artísticas e políticas obviamente o enganaram. O New Republic julgou o filme "de razoável a sentimental", potencialmente "um grande filme" arruinado pela "pequenez da estrutura narrativa", com mais Odets do que o necessário. O Time reclamou das "técnicas esfarrapadas" que roubaram do filme "muito de sua força". ${ }^{142}$
\end{abstract}

De acordo com o crítico William S. Pechter, Force of Evil estava fadado a uma "morte insignificante, um filme de gângster com pouca violência, uma história de amor sem apoteose romântica, um filme de Hollywood sem um final feliz" "143. Fato é que Force of Evil só foi reconhecido como um grande filme tempos depois e, num primeiro momento, fora de território norte-americano. Foi na França, por exemplo, que os críticos de cinema, depois de finalmente terem acesso às produções norte-americanas após o período de guerra, viram o clima de cinismo e pessimismo nos filmes produzidos a partir da década de 1940 nos EUA e cunharam o termo film noir para descrevê-los. Para o crítico Paul Schrader, o termo não define exatamente um gênero de filmes específico, mas sim um período histórico (do início da década de 1940 até meados da década seguinte) em que os filmes registravam um mundo de "cidades com ruas sombrias e escorregadias, crime e corrupção"144. O ambiente político nos EUA nesse período histórico contribuiu para a formação do noir, segundo Buhle e Wagner:

\footnotetext{
${ }^{142}$ Buhle, P., Wagner, D. A very dangerous citizen: Abraham Polonsky and the Hollywood Left. Berkeley and Los Angeles: University of California Press, 2001, p. 122.

${ }^{143}$ Pechter, W. S. Conversations with Abraham Polonsky/1962\&1968. In: Polonsky, A. Abraham Polonsky: interviews / edited by Andrew Dickos. Jackson: University of Mississippi Press, 2013, p. 34.

${ }^{144}$ Schrader, P. Notes on Film Noir. In: Silver, A.; Ursini, J. (ed.) Film Noir Reader. Pompton Plains: Limelight Editions, 1996, p. 53-54.
} 
O gosto amargo que varreu a América nos anos imediatamente após a guerra foi direcionado muito menos ao comunismo ou aos comunistas do que ao desaparecimento do idealismo dos tempos de guerra e ao retorno à rotina dos negócios - inclusive os mais repugnantes - na vida Americana. Imensas ondas de greves - as maiores desde os primeiros dias da CIO [Congress of Industrial Organizations] - dessa vez expressavam revolta tanto contra sindicatos como contra empregadores; a música popular ecoava com temas amargurados sobre alienação e traição; e a popularidade do Presidente Harry Truman despencou durante o período de 1945-1946. Todo esse ódio formava o contexto do cinema noir, do qual Polonsky foi um dos melhores praticantes. ${ }^{145}$

Os filmes desse período chamaram a atenção de críticos de esquerda, como Thom Andersen, que classificou Force of Evil e outros doze dos filmes produzidos entre a primeira e a segunda leva de audiências do HUAC (1947 a 1951) em uma derivação do film noir por ele denominada film gris, caracterizada por personagens oriundos da classe trabalhadora, enredos com maior realismo social e psicológico que denunciavam o embuste do American Dream, e uma "consciência amarga da pobreza e da luta de classes" ${ }^{146}$. Segundo o crítico Dennis Broe, o

\begin{abstract}
film noir denota um momento na história do crime film onde ideias da esquerda dominavam e, por um breve momento, ditavam a estrutura do gênero. Essa hegemonia da esquerda em um gênero da indústria cultural por um curto período (1945-1950) representou na tela o encontro de um bloco dominante de interesses das classes trabalhadora e média. Isso ocorreu em um momento em que a consciência da classe trabalhadora aumentou devido a uma série de greves, tanto no país como um todo como em Hollywood em particular, e quando a preocupação da classe média com o crescimento das corporações vivia seu auge. ${ }^{147}$
\end{abstract}

Dentro da categoria dos crime films, o gênero gângster já havia sofrido variações ao longo da década de 1930 e 1940 devido à censura e às demandas do mercado. Force of Evil, no entanto, se destaca de produções anteriores por refuncionalizar os elementos que a narrativa tradicional de gângster oferecia (ascensão e queda do criminoso, American Dream, a figura do delator, entre outros) a fim de que a matéria histórica envolvida nas condições de

\footnotetext{
${ }^{145}$ Buhle, P., Wagner, D. A very dangerous citizen: Abraham Polonsky and the Hollywood Left. Berkeley and Los Angeles: University of California Press, 2001, p. 132.

${ }_{146}$ Andersen, T. Red Hollywood. In: Ferguson, S., Groseclose, B. Literature and the Visual Arts in Contemporary Society. Columbus: Ohio State University Press, 1985, p. 186-187.

${ }^{147}$ Broe, D. Film Noir, American Workers, and Postwar Hollywood. Gainesville: University Press of Florida, 2009, location 1001-1002 (Kindle Edition).
} 
produção viesse à tona. A sofisticação na forma e no conteúdo em Force of Evil também nos obriga a observar a representação da classe trabalhadora no filme sob diferentes aspectos, inclusive quanto à questão da divisão intraclasses e da aliança de classes. Daremos início às nossas considerações sobre o filme observando como Polonsky nos apresenta os personagens da narrativa e quais recursos técnicos o diretor utiliza na introdução do filme.

\section{Equivalência entre negócios e crime}

Force of Evil se inicia com uma tomada em plano geral do alto dos prédios de Wall Street, tendo, ao centro do enquadramento, o topo da Trinity Church. É possível ouvir, ao fundo, o badalar dos sinos da igreja, misturado ao tema musical de Force of Evil - iniciado ainda durante a abertura do filme - que diminui gradualmente de volume. A câmera desce em tilt para mostrar o movimento dos carros na rua e das pessoas em passo apressado. Enquanto isso, escutamos em voz-over o narrador: "Essa é Wall Street. Hoje era um dia importante. Porque amanhã, 4 de julho, eu pretendia ganhar meu primeiro milhão de dólares. Um dia importante na vida de qualquer um" ${ }^{\prime 148}$.

A cena é filmada em plano geral sob a perspectiva do alto dos prédios de Wall Street. O narrador continua: "Por enquanto, o empreendimento era um pouco ilegal". Há um fadeout e a imagem da rua é substituída pelo hall de entrada de um dos prédios filmado em plano médio. Nesse momento, a câmera está posicionada dentro de uma banca de jornal. Desse ponto de vista temos, em primeiro plano, um jornaleiro e os seus clientes. Em segundo plano estão os elevadores do prédio. O movimento de pessoas no hall é intenso, e algumas delas param rapidamente diante da banca para fazer apostas. À direita da cena, aproxima-se um homem de terno e chapéu escuros, que começa a escolher jornais no balcão e é cumprimentado pelas outras pessoas, que se dirigem a ele como Sr. Morse. Ao contrário dos outros clientes da banca, Joe Morse não faz apostas. Essas continuam sendo realizadas de maneira rápida e informal - o apostador somente entrega o valor ao jornaleiro, e diz o quanto quer apostar e em qual número, o que demonstra que a atividade é corriqueira (Figura 17).

\footnotetext{
${ }^{148}$ As citações da narração e dos diálogos de Force of Evil têm como base as legendas do DVD.
} 


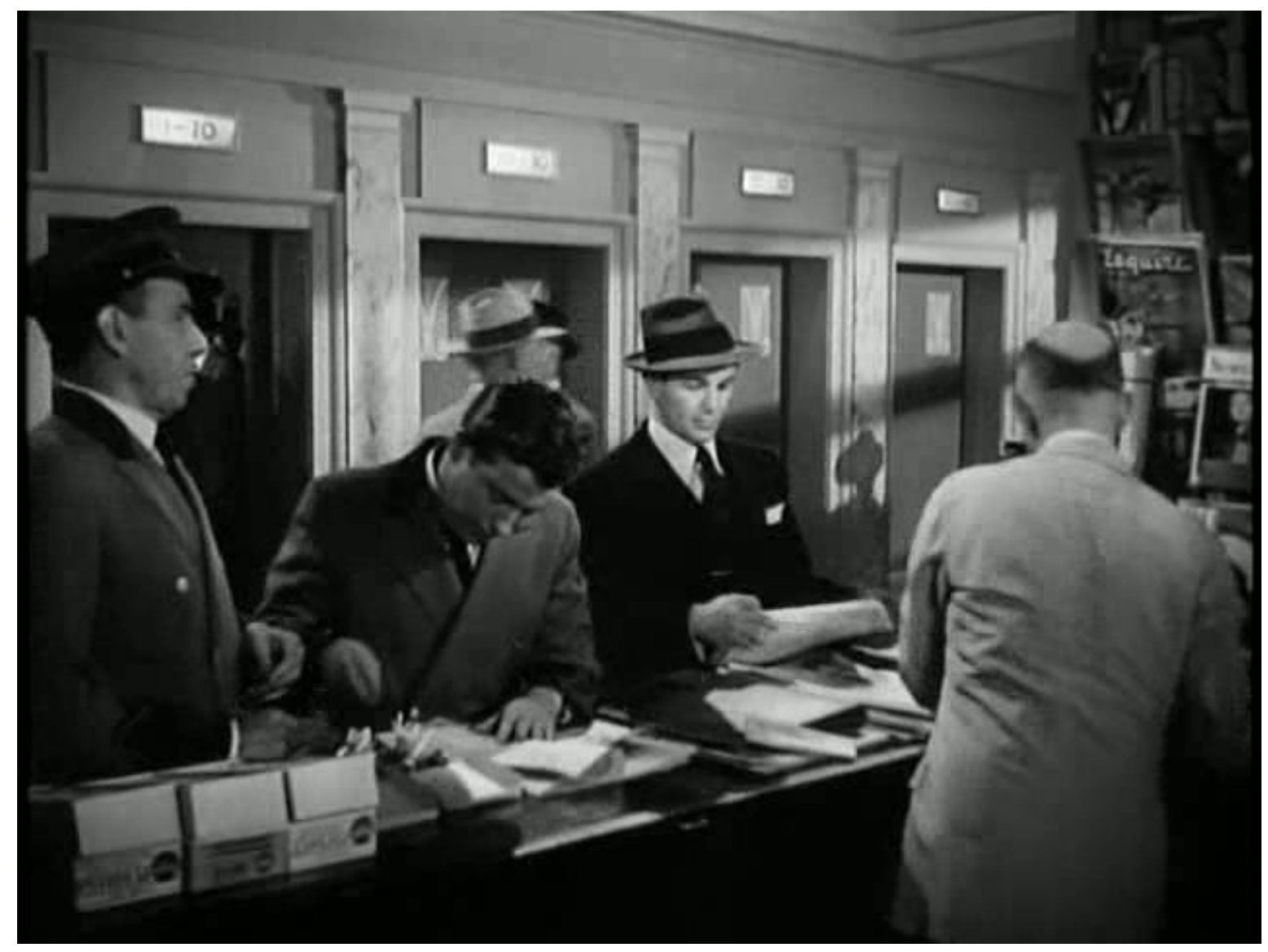

Figura 17 - A banca de jornais no prédio em Wall Street.

Enquanto Joe escolhe os jornais que vai levar, dois homens conversam sobre a loteria. É possível observar que os protagonistas do diálogo em questão trajam o mesmo uniforme, levando o espectador a crer que são trabalhadores do próprio prédio em que se encontram. Há uma diferença evidente entre o uniforme que vestem e o terno de Joe. "Que tal isso, Bob?", pergunta um deles. Há um corte para um close de um jornal no qual se lê: "Número da sorte de hoje: 114". Novo corte, e o diálogo prossegue: "O número da sorte de hoje é 114. Apostei dez centavos no 113, não foi?", ele pergunta. "Sim”, uma voz responde em off. "Só não ganhei sessenta dólares por causa de um dígito. 600 para 1". "Vai apostar 776 amanhã?", Bob pergunta. "Não, 823. Hoje de manhã quase fui atropelado. Sabe qual era a placa? 823".

Nesse momento há um corte para um plano americano de Joe ajeitando os jornais. A voz do trabalhador continua em off. "Se depender de hoje, é meu número de sorte”. Joe estica o braço para alcançar algo à frente dos dois apostadores. Um deles toca o braço de Joe e pergunta-1he: "Estou certo, Sr. Morse?". "Se ninguém te matar, é um dia de sorte para qualquer um", ele responde, e todos na cena sorriem, enquanto Joe dirige-se a um dos 
elevadores do prédio. Outro apostador, também de uniforme, chega e faz uma aposta de cinco centavos no número 776.

Vemos um novo fade out e na cena seguinte há um plano médio do andar em que Morse desce do elevador. A câmera acompanha em pan shot os passos do protagonista, que se dirige a uma porta com uma placa colocada acima dela na qual está escrito "Wheelock and Morse". Enquanto isso, Joe explica, em voz-over, os detalhes do jogo: "Os otários apostam em qualquer combinação de três números selecionados dos totais apostados em algum hipódromo aquele dia”. Nesse momento fica evidente que Joe é tanto o narrador quanto o protagonista da narrativa. Ele entra pela porta do escritório e passa rapidamente pela recepção e por mais uma sala até chegar à sua. No caminho, o protagonista cumprimenta os funcionários rapidamente. O narrador continua: "20 milhões de apostadores por dia nos Estados Unidos. A renda anual dos pequenos golpistas e apontadores dos jogos era de mais de US\$ 100 milhões". Quando Joe finalmente abre a porta de sua sala, ele finaliza: "Era uma pena que tanto dinheiro fosse parar no bolso dos outros".

A sequência de abertura do filme apresenta o uso de alguns procedimentos técnicos que chamam a nossa atenção. Em primeiro lugar, o tilt da cena inicial. Com um movimento de câmera que mostra do topo dos arranha-céus de Wall Street até a rua, temos uma metáfora visual do percurso de Joe Morse ao longo de Force of Evil. O protagonista inicia o filme planejando seu primeiro milhão de dólares em um escritório "nas nuvens" - como ele próprio define em uma conversa com seu irmão Leo -, mas acaba a narrativa encontrando o irmão morto às margens do rio Hudson.

O segundo elemento que nos chama a atenção nessa sequência é a presença do narrador-protagonista, comum no cinema noir. Pela utilização dos tempos verbais, sabemos que o narrador de Force of Evil nos conta a história de um determinado ponto no futuro. Em comum com outros filmes do período, temos o fato de que a narrativa de Force of Evil é enviesada pelo ponto de vista do narrador-protagonista. No entanto, ao contrário de Double Indemnity (Billy Wilder, 1944) e outros filmes do gênero, o procedimento em Force of Evil é diverso de duas maneiras. Em primeiro lugar, ao explicar os detalhes da loteria ilegal, o narrador do filme de Polonsky aproxima-se do narrador do teatro épico, que faz do espectador um observador ativo ao proporcionar-lhe conhecimentos e um ponto de vista crítico e distanciado da ação. Tal aproximação, contudo, ocorre ainda de maneira dissimulada, sob as convenções do cinema noir, cujo narrador introduz o conflito ao 
espectador e transporta-o para dentro da ação. ${ }^{149}$ Em segundo lugar, ao contrário do cinema noir tradicional, cujas narrações tratam de episódios particulares nas vidas dos protagonistas com alcance social restrito, em Force of Evil as ações do narrador-protagonista e seus associados têm consequências mais amplas no cotidiano de outros personagens - a começar pela conquista do monopólio do jogo de azar por Ben Tucker e a quebra da banca de seu irmão e de dezenas de outros proprietários. Force of Evil mostra que os efeitos dos negócios, legais ou não, afetam a sociedade como um todo.

O jogo de azar, por sinal, é mais um elemento da narrativa apresentado ao espectador nessa sequência inicial que merece ser avaliado mais detidamente. Na primeira cena em que vemos referência ao jogo, Polonsky opta por filmar a cena na banca de jornal em plano médio - um procedimento recorrente em vários momentos do filme -, o que insere os personagens num contexto específico, e mostra a relação deles com as outras pessoas ao seu redor. Nesse caso, o que se nota na cena é uma diferença bem clara entre os apostadores e Joe. Enquanto os primeiros são trabalhadores braçais que vestem uniformes, o último é um advogado vestido com um terno bem alinhado.

Há, dessa maneira, uma associação apresentada desde o início do filme entre o negócio ilegal, Wall Street, e o jogo. O primeiro é consequência do crime organizado, que teve seu ápice nos Estados Unidos com o contrabando de bebida durante a Lei Seca nos anos 1920 e estruturou a forma mais lucrativa de se realizar negócios no país. O segundo é utilizado em Force of Evil como símbolo do capitalismo norte-americano, o sistema que, como o diretor nos mostrará ao longo do filme, não só rege a economia do país, mas também influencia as relações humanas. Em terceiro lugar, o jogo introduz nessa associação uma relação entre o acaso e o capitalismo. Sobre a relação do mercado financeiro com o jogo, o crítico cultural alemão Walter Benjamin diz o seguinte em seu ensaio "Jogo e Prostituição":

\footnotetext{
“É impossível esperar que um burguês consiga um dia compreender o fenômeno da distribuição de riquezas. Pois, na medida em que a produção mecânica se desenvolve, a propriedade se torna despersonalizada e revestida com a forma coletiva, impessoal das sociedades anônimas, cujas cotas sociais terminam por girar no turbilhão da Bolsa... Alguns perdem essas cotas e outros as adquirem, e de uma forma tão semelhante à do jogo que as operações da Bolsa são chamadas de jogo. Todo o desenvolvimento econômico moderno tem a tendência a transformar a sociedade capitalista cada vez mais numa gigantesca casa de jogo
}

${ }^{149}$ Cf. Szondi, P. Teoria do Drama Moderno (1880-1950). São Paulo: Cosac Naify, 2001, p. 116-117. 
internacional, onde os burgueses ganham e perdem capitais em consequência de acontecimentos que lhes permanecem desconhecidos. $\mathrm{O}$ 'inescrutável' exerce seu domínio na sociedade burguesa como num antro de jogo... Sucessos e fracassos oriundos de causas inesperadas, geralmente desconhecidas, e aparentemente dependentes do acaso, predispõem o burguês ao estado de ânimo do jogador... O capitalista, cuja fortuna está investida em valores da Bolsa, e que ignora as causas das oscilações dos preços e dividendos desses títulos, é um jogador profissional. $(\ldots)^{\prime 150}$

De acordo com a historiadora Ann Fabian, na loteria estão "as promessas do capitalismo sem os seus processos" ${ }^{151}$, ou seja, a possibilidade de o trabalhador mudar de classe social sem que ele precise vender sua força de trabalho. No entanto, como o próprio filme nos mostra, até mesmo essa mobilidade social pode ser planejada, forçando o "acaso", citado por Walter Benjamin, a trabalhar em benefício do criminoso. De acordo com Paul Buhle e Dave Wagner,

Joe Morse explica a misteriosa ciência de acumular fortuna por meio das pequenas esperanças coletivas de otários que apostam tendo chances ínfimas, e por um breve momento o espectador se pergunta o que, afinal de contas, aquilo tem a ver com Wall Street, onde a nomenclatura de procedimentos financeiros é muito mais refinada. No entanto, logo se percebe que o conflito entre aparência e realidade é justamente a questão: esses pequenos criminosos, incluindo Joe, podem ter graduação em Direito em instituições de elite, vestir chapéus de seda, fumar cachimbos, e ter escritórios "nas nuvens", mas continuam sendo pequenos criminosos. ${ }^{152}$

Segundo o pesquisador Don Liddick, a loteria ilegal norte-americana (numbers game) mostrada em Force of Evil tem origem na década de 1920 e movimentava, ao fim da década de 1990, cerca de US\$ 500 milhões por ano só na cidade de Nova Iorque - por meio da narração de Joe na abertura de Force of Evil, sabemos que esse número girava em torno de US\$ 100 milhões por ano na época em que o filme foi produzido. Entre os fatores que explicam a popularidade do jogo estão os prêmios (650:1) maiores do que os das loterias federais (500:1), e o fato de que não é preciso declarar como renda os ganhos nessa loteria -

\footnotetext{
${ }^{150}$ Lafargue, P. apud Benjamin, W. Jogo e Prostituição. In: Benjamin, W. Charles Baudelaire: um lírico no auge do capitalismo. $1^{\text {a }}$. ed. São Paulo: Brasiliense, 1989, p. 247.

151 Fabian, A. Card sharps and bucket shops: gambling in nineteenth-century America. New York: Routledge, 1999, p. 124.

152 Buhle, P., Wagner, D. A very dangerous citizen: Abraham Polonsky and the Hollywood Left. Berkeley and Los Angeles: University of California Press, 2001, p. 119.
} 
se considerarmos que quem aposta nesse tipo de jogo já está infringindo a lei, sonegar impostos não seria um problema. Outra característica do numbers game, segundo Liddick, é que o jogo, depois de setenta anos sendo operado por organizações criminosas e oficiais públicos corruptos, faz parte da cultura urbana de muitas cidades dos EUA - como o filme nos mostra, a própria imprensa aproveita-se desse mercado ao divulgar o "número da sorte" do dia no jornal para, dessa maneira, aumentar sua circulação; além disso, os operadores do jogo são conhecidos historicamente por ajudarem as comunidades locais mais do que os próprios poderes públicos. Sendo assim, o apoio a esses empresários muitas vezes faz mais sentido ao apostador do que a cooperação com o governo, que pouco faz em nome de comunidades pobres. ${ }^{153}$

Mais adiante no filme, vemos uma passagem que explica ao espectador como esse plano funcionará. Na cena estão reunidos Joe, Tucker, Johnson (Tim Ryan, um dos capangas de Tucker), Bunty (Raymond Largay) e Taylor (Sid Tomack) no escritório do gângster. Joe repassa o plano com Taylor, que será responsável pela operação:

Joe: Tenho US\$ 25 mil para você brincar, Two \& Two. É o suficiente?

Taylor: Eu te devolvo o troco.

Joe: [dirigindo-se a Johnson] Ele sabe exatamente o que fazer?

Johnson: Falei o dia todo, ele sabe de cor.

Joe: [dirigindo-se a Taylor] Que número queremos?

Taylor: 776. Não se preocupe, Sr. Morse. Vai dar 776. Primeiro, faço a última aposta na terceira corrida. Johnson já combinou tudo com os balconistas para me ajudar com isso. Segundo, aposto o suficiente para fazer os três últimos números do pagamento serem 7, 7 e 6. Terceiro, o troco dos $\$ 25$ mil que você me deu, eu devolvo para Johnson. Ou estarei em apuros com Johnson. Quarto, assim que aparecer o 776 no painel de apostas, eu confirmo no telefone do Sr. Morse: Bowling Green, 75432. Cinco, encontro Johnson em seu escritório amanhã às nove horas noite, e recebo o pagamento.

Johnson: [batendo no ombro de Taylor] E o juramento? O juramento!

Taylor: [falando rapidamente com a mão direita levantada] Juro pela minha morte e pela Bíblia que não vou contar a ninguém e esquecer como fiz isso, ou estarei em apuros com Johnson.

Joe: Ótimo. [rasga um pedaço de jornal com uma notícia mostrando os ganhos de diversas companhias naquela semana e entrega para Taylor] Me dê a soma disso. Taylor: [pensa alguns segundos e diz] 784.324.

${ }^{153}$ Cf. Liddick, D. The Mob's Daily Number: Organized Crime and the Numbers Gambling Industry. Lanham: University Press of America, 1999, p. 1-2. 
Joe: [anotando os números num papel] Pode repetir, por favor?

Taylor: 784.324. [Joe pega o pedaço de jornal de volta e começa a somar os números numa calculadora. Nesse instante, Bunty, um dos presentes à reunião pergunta a Tucker]

Bunty: Ben, eu estava pensando. Estão todos pisando em ovos na cidade. Gostaria de saber se a gente não pode ir mais devagar com as coisas por enquanto.

Joe: [enquanto opera a calculadora] Bunty, cuide da política que eu cuido dos negócios. É uma operação normal. 776 vai sair amanhã por que o Taylor vai cuidar disso. Amanhã à noite, todos os bancos estarão falidos. Nós entramos com o empréstimo do dinheiro a quem nos interessar e o resto que se dane. [pequena pausa] Somos credores normais.

Bunty: A cidade não está normal desde que Hall foi nomeado. [Joe termina os cálculos e vê que o resultado da soma bate com o que Taylor havia lhe dito]

Johnson: Ele ganha o charuto [entregando os números para Tucker]

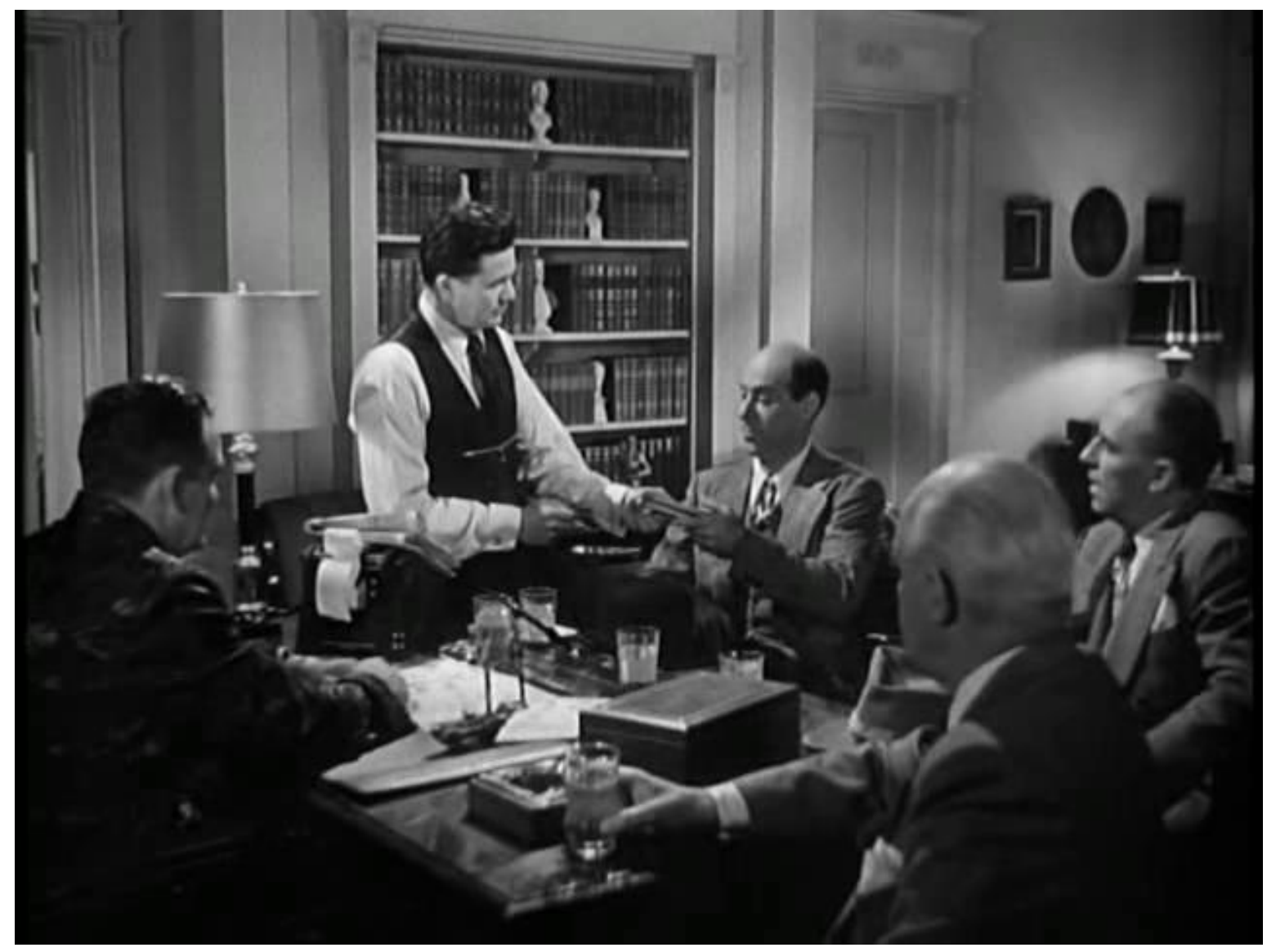

Figura 18 - Joe repassa o plano com Taylor. 
Segundo Liddick, os números ganhadores do numbers game eram retirados, até 1931, da Câmara de Compensação de Nova Iorque, que interrompeu a divulgação de números exatos assim que descobriu que eles eram utilizados com esse fim. Em seguida, os operadores passaram a utilizar valores das ações divulgados pela Bolsa de Valores de Nova Iorque, que passou a publicar valores aproximados ou arredondados. A partir desse momento, a indústria da loteria adotou diferentes métodos para determinar o número ganhador. No caso de Force of Evil, o método adotado é chamado Brooklyn number, que era

\begin{abstract}
derivado do total de apostas do dia em uma determinada corrida de cavalos. Os três números à esquerda dos centavos formavam o número ganhador. Por exemplo, se $\$ 548,227.50$ fosse o total de apostas de um determinado dia, o número ganhador seria $227 .{ }^{154}$
\end{abstract}

Outros métodos surgiram com o passar do tempo, mas o total de apostas nas corridas de cavalos era o preferido dos apostadores porque era considerado um método "verdadeiramente aleatório e quase impossível de ser manipulado"155. O que a cena descrita acima demonstra é que Joe e Tucker, sabendo dessa dificuldade, executam o que qualquer companhia normalmente faz quando precisa de mão-de-obra especializada: contratam um freelancer. Taylor funciona como um funcionário terceirizado especialista em contas contratado pela Tucker Enterprises Inc. somente para manipular o total de apostas e concretizar o plano. Dessa maneira, "é uma operação normal", como assinala Joe, e tanto o mise en scène como a atuação nos leva a acreditar nisso: a reunião ocorre na casa de Tucker e o diálogo é muito mais formal e relacionado aos negócios (fala-se em grandes somas de dinheiro, empréstimos, falências) do que nos filmes de gângster da década de 1930, em que as reuniões de criminosos normalmente ocorriam em esconderijos, nos fundos de um bar ou de um clube, e os gângsteres se comunicavam de maneira extremamente informal, por meio de gírias. Se compararmos a cena de reunião em Force of Evil com aquelas que vimos em Little Caesar, por exemplo, fica evidente que no primeiro o crime organizado é tratado como norma, enquanto no segundo ele é retratado como desvio. Tal equivalência entre negócios legais e ilegais no enredo, bem como nos diálogos ("Somos credores normais", de acordo com Joe) aparece reiteradamente ao longo de Force of Evil e será objeto de nossa análise o longo desse capítulo.

\footnotetext{
${ }^{154}$ Liddick, D. The Mob's Daily Number: Organized Crime and the Numbers Gambling Industry. Lanham: University Press of America, 1999, p. 4.

155 Ibidem, p. 5.
} 
Retomando a sequência de abertura descrita anteriormente, um último aspecto importante é a distinção que o narrador-protagonista faz entre si próprio e os apostadores do jogo. Morse chama-os de otários ("suckers"), uma vez que as chances de se ganhar no jogo eram ínfimas, e é justamente por meio das apostas desses otários e suas crenças em uma superstição $^{156}$ que ele pretende fazer seu primeiro milhão de dólares. No entanto, esse tratamento se torna problemático quando sabemos, mais adiante, que Joe tem raízes bem mais humildes que sua atual condição de advogado de um grande escritório em Wall Street. Em última análise, seu comportamento pode ser considerado uma das muitas traições presentes no filme - nesse caso específico, de classe. Polonsky problematiza ainda mais essa discussão ao estabelecer uma relação complexa entre Joe e seu irmão Leo. A descrição e a análise das cenas seguintes tratarão dessa questão.

\section{Tucker Enterprises Inc.}

Depois de discutir com seu sócio Hobe Wheelock (Paul McVey) sobre sua relação com Tucker, Joe vai até a casa de seu cliente. A sequência na casa de Tucker se inicia com um plano americano dentro do escritório do gângster: a câmera mostra, em primeiro plano, a porta do cofre de Tucker à esquerda, onde é possível ler a inscrição "Tucker Enterprises Inc.”, enquanto Joe permanece à direita. Não é possível ver Tucker por inteiro em cena a princípio, somente uma mão que surge atrás da porta do cofre pegando o dinheiro que o advogado lhe entrega. (Figura 19) Enquanto recebe o dinheiro, Tucker pergunta quanto há ali. "Vinte e cinco mil, e há mais sessenta no cofre", Joe diz. "Tem mais cinquenta mil aqui, é mais do que suficiente", Tucker responde, enquanto se levanta. O gângster é alto, corpulento, e veste um terno de cor clara, lenço no bolso do paletó e gravata. Ele segue até sua cadeira, coloca seus óculos e começa a fazer anotações em um bloco de papel. Um grande relógio e um quadro decoram as paredes do escritório. Por meio da fala do gângster nessa cena, o espectador descobre que Joe pretende fazer o seu primeiro milhão de dólares ajudando Tucker a criar um monopólio da loteria ilegal em Nova Iorque. O dinheiro do cofre seria utilizado para comprar as doze maiores bancas de apostas da cidade, e uma menor - a

\footnotetext{
${ }^{156}$ De acordo com o filme, há uma superstição de que o número 776 seja o "número da sorte" no feriado do dia 4 de julho - 1776 é o ano da Declaração de Independência dos Estados Unidos.
} 
de Leo Morse. O restante "pode quebrar e a organização pode tomar conta dos negócios", segundo Tucker.

Por meio da composição dos planos, dos diálogos, e dos elementos da cena descrita acima, o espectador percebe que o gângster de Force of Evil não é o criminoso truculento de arma em punho que se esperaria de um filme desse gênero, mas, sim, um homem de negócios bem-sucedido. Além disso, ao esconder Tucker atrás da porta do cofre na primeira cena e mostrar somente sua mão pegando os maços de dinheiro, Polonsky cria uma metonímia não verbal, em que a mão do gângster representa o movimento monopolista do grande capital (no caso, a Tucker Enterprises Inc., como mostra a inscrição em letras garrafais no cofre), que se alimenta do pequeno capital (as pequenas bancas de apostas) e o destrói - Polonsky organizou seu roteiro a fim de concentrar seus esforços justamente nas consequências dessa destruição: a presença de gângsteres na banca de Leo, o endividamento dos banqueiros, a perseguição a Bauer, o grampo no telefone de Joe, e, finalmente, a morte de Leo.

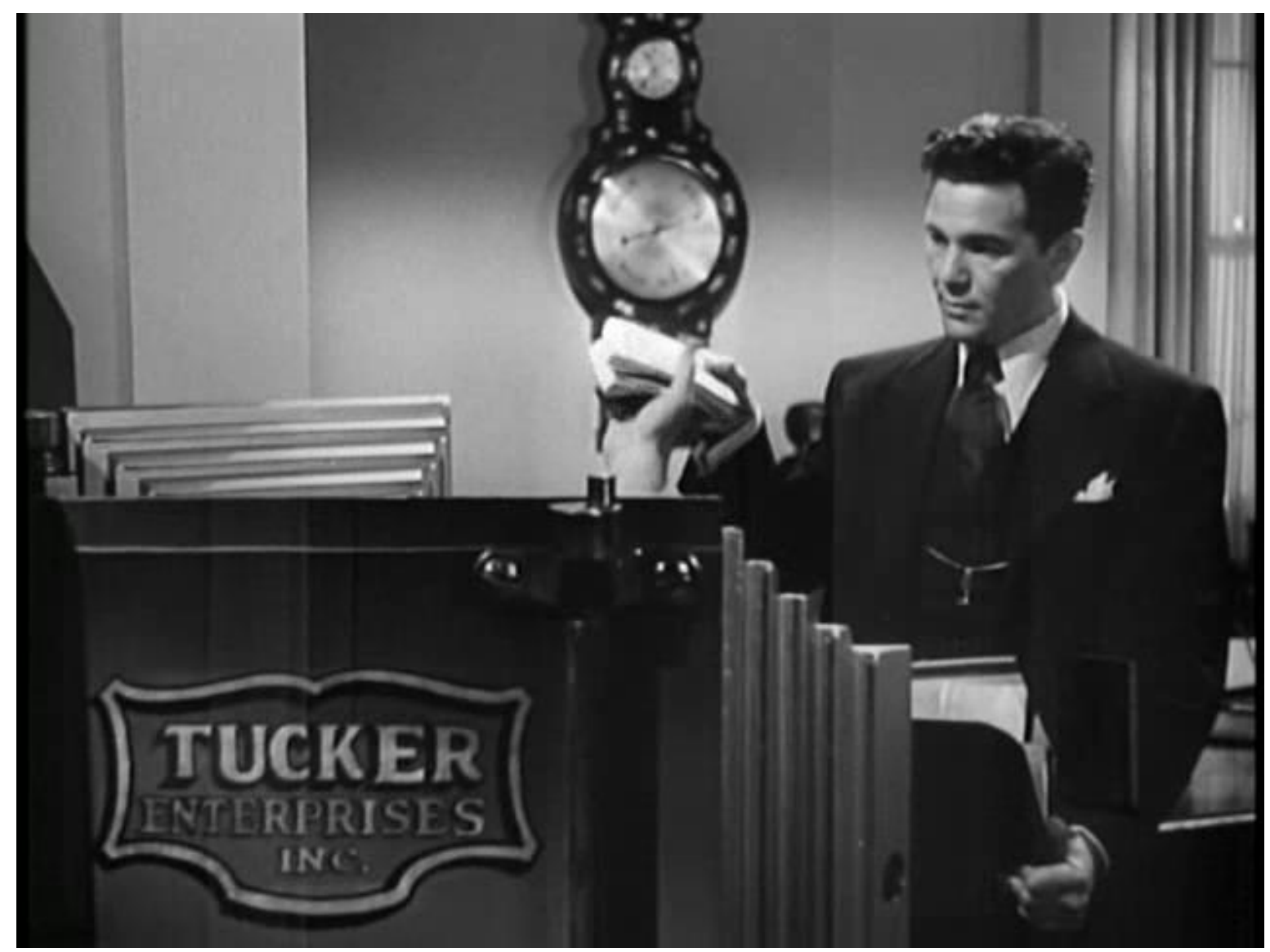

Figura 19 - Joe entrega maços de dinheiro a Tucker. 
A cena continua com Tucker perguntando a Joe se ele vai encontrar Leo. Temos, então, o seguinte diálogo:

Joe: Posso ser franco com você, Ben?

Tucker: [retira os óculos, fecha uma pasta com suas anotações e dirige-se ao cofre] Edna sempre me diz isso. Ela diz: "Vou ser franca, Ben". E aí diz algo cruel e terrível sobre mim. [coloca a pasta dentro do cofre, que tem um busto de bronze apoiado sobre ele] Ou algo tolo sobre ela mesma. [sai do plano]

Joe: [corte para um plano americano que mostra Joe sentado sobre a mesa de Tucker, registrado entre o quadro e o relógio na parede] Eu serei tolo, Ben. Sou um advogado, seu advogadozinho esperto, e estou gerenciando esse monopólio de loterias para torná-lo legal, respeitável e muito rentável para você. E estou fazendo isso por dois motivos.

Tucker: [corte para Tucker colocando café em uma xícara] Qual o segundo motivo?

Joe: O primeiro é realmente dinheiro. [pausa; Joe caminha em direção a Tucker, a câmera acompanha o movimento e enquadra Joe, em pé, à direita, e Tucker, sentado, à esquerda] Mas o segundo motivo é meu irmão. Ele é um homem de 50 anos com problemas cardíacos. Quando 776 bater amanhã e destruir seu capital, vai acabar com a vida dele. Ele vai ter um susto e morrer. É uma vergonha ser velho e falido. Esse é o meu problema. Ele só vai entrar no acordo se eu o forçar, e não posso forçá-lo a não ser que eu fale do 776 .

Tucker: [inicia-se uma sequência de campo e contracampo] Você não vai falar nada.

Joe: É o único jeito, Ben.

Tucker: [levantando-se] É o único jeito de nos arruinar! [levantando a voz] Não! Joe: Garanto que é seguro!

Tucker: Não! [corte para um plano americano dos dois personagens de frente um para o outro; Tucker diz em tom de ameaça] É melhor você nem ir ver seu irmão. Olha, Joe. Vamos esclarecer as coisas. Amanhã é 4 de julho, o único dia do ano quando há a superstição do número 776. Amanhã cada centavo de cada otário vai para o 776. Certo?

Joe: Certo.

Tucker: Daremos um jeito para esse número sair, e os banqueiros irão à falência, pois não têm como pagar as apostas. [há um corte e a câmera começa a acompanhar Joe e Tucker descendo as escadas da mansão do gângster; a cena é filmada em plongée] Eu não precisava ter investido todo esse dinheiro, eu poderia ter chamado meu ex-parceiro de cerveja Ficco e seus capangas de Chicago, e ter tomado as bancas. Como fiz com a bebida em [19]27. Mas você disse que não. Você é meu advogado esperto, não é? 
Joe: Sim.

Tucker: Você disse que ia mexer com a opinião pública para fazer a lei passar, tornando a nossa loteria um negócio legal, como em Cuba e na Irlanda, e como as apostas em corridas são aqui. Qualquer ação violenta iria acabar com as nossas chances, e eu disse: "Tudo bem, Joe". Certo?

Joe: Certo.

Tucker: Não tenho culpa se você tem problemas com seu irmão mais velho, Joe. Não posso arriscar duzentos mil dólares por motivos sentimentais. Não se preocupe com seu irmão, Joe. Ele não morrerá do coração se lembrar que tem um irmão rico. Parentes ricos são melhores do que médicos ou remédios.

Joe: OK, Ben, OK.

Tucker: Lembre-se, Joe: só você e eu sabemos do 776. Eu não preciso contar para ninguém. [corte para uma tomada em plano americano de Joe e Tucker]

Joe: [rispidamente, pegando o seu chapéu das mãos de Tucker] Não confia em $\operatorname{mim}$ ?

Tucker: Claro que confio. Só quero que saiba o quanto estou preocupado. [Tucker abre a porte a Joe sai]

No âmbito da linguagem utilizada nessa cena, chama-nos a atenção a ironia ("E estou fazendo isso por dois motivos". “Qual o segundo motivo?”) e o sarcasmo (“Ele não morrerá do coração se lembrar que tem um irmão rico. Parentes ricos são melhores do que médicos ou remédios".) - recursos utilizados repetidas vezes ao longo do filme com o objetivo de despertar o espírito crítico do espectador. Por meio do diálogo descobrimos a origem da fortuna de Tucker: o contrabando de bebida alcoólica durante a Lei Seca, um tema recorrente em filmes de gângster empregado em Force of Evil como uma referência à brutalidade dos negócios de Tucker deixados no passado, a partir de um conselho de seu advogado - dessa forma, enquanto o modus operandi do gângster no passado consistia em usar força bruta para conseguir o que queria, hoje Tucker é o homem de negócios per se, que está na mais alta escala de poder, delega funções a seus subordinados e concentra todas as decisões. Finalmente, é nesse diálogo que se estabelece a aliança de classes entre o capitalista e o trabalhador de "colarinho branco" (white collar worker) em nome do "primeiro milhão de dólares" do advogado, ao mesmo tempo em que Joe apresenta o conflito central da trama: a contradição entre as demandas dos negócios de Tucker e o comprometimento de Joe com Leo.

No que diz respeito aos recursos visuais e cenográficos, podemos destacar dessa sequência a própria mansão de Tucker, cuja decoração, de acordo com Polonsky, 
sugere poder e autoridade. Desse modo, quando você resolve retratar essa história, que é, na verdade, uma análise destrutiva do sistema, a decoração oferece a tensão necessária para romper com a situação dada. ${ }^{157}$

Além de sugerirem "poder e autoridade", a decoração da mansão de Tucker também implica na determinação de um conflito de classes, principalmente se levarmos em conta a visita de Joe à banca de Leo, que ocorre logo em seguida.

Outro ponto que merece destaque é a rima visual que essa cena estabelece com a sequência final, em que o protagonista desce ladeiras e escadas até chegar à margem do rio Hudson para encontrar o corpo de Leo. Joe e Tucker demoram-se na escada, fazem pausas, conversam, e o plano segue essa movimentação lenta sem interrupção. "Eles estão indo em direção ao inferno", diz Polonsky, "mas no começo, parece que eles estão apenas descendo uma grande escada. Somente mais tarde você descobre para onde estão indo"158.

Por último, é preciso ressaltar o desajuste entre o acabamento estético do registro e o conteúdo do diálogo entre Joe e Tucker. Um dos recursos técnicos utilizados nessa cena é a longa duração do plano em plongée realçando o jogo de luz e sombra, que desenha retas e curvas nas paredes da mansão (Figura 20). Em entrevista ao crítico John Schultheiss, Polonsky revela como o tipo de luz que seria utilizada em Force of Evil foi tema de discussão entre ele e George Barnes, diretor de fotografia que já havia trabalhado com Alfred Hitchcock na década de 1940:

Fizemos um dia de testes de gravação para ter uma ideia do visual do filme. Ele [Barnes] fez tudo parecer bonito demais; não era esse aspecto que eu gostaria que tivesse. Não era desse jeito que estava escrito. Então ele me disse: “Apenas me diga o que você quer que eu consigo para você". Eu não sabia o que dizer a ele. Então eu comprei um livro de pinturas de Edward Hopper. Quando eu mostrei a Barnes o livro de pinturas, ele respondeu: "Por que você não disse logo? - você quer uma única fonte de luz [low key lighting, tipo de iluminação que privilegia o contraste entre luz e sombra]. Nos dias seguintes, lá estava: Barnes conseguiu o efeito pictórico que eu queria com essa técnica de iluminação. O filme todo é baseado nesse conceito. ${ }^{159}$

\footnotetext{
157 Sherman, E, Rubin, M. Interview with Abraham Polonsky. In: Polonsky, A. Abraham Polonsky: interviews / edited by Andrew Dickos. Jackson: University of Mississippi Press, 2013, p. 56. ${ }^{158}$ Idem.

159 Schultheiss, J. Annotations to the Screenplay. In: Force of Evil: The Critical Edition, by Abraham Polonsky. Northridge: The Center for Telecommunication Studies California State University, 1996, p. 131.
} 

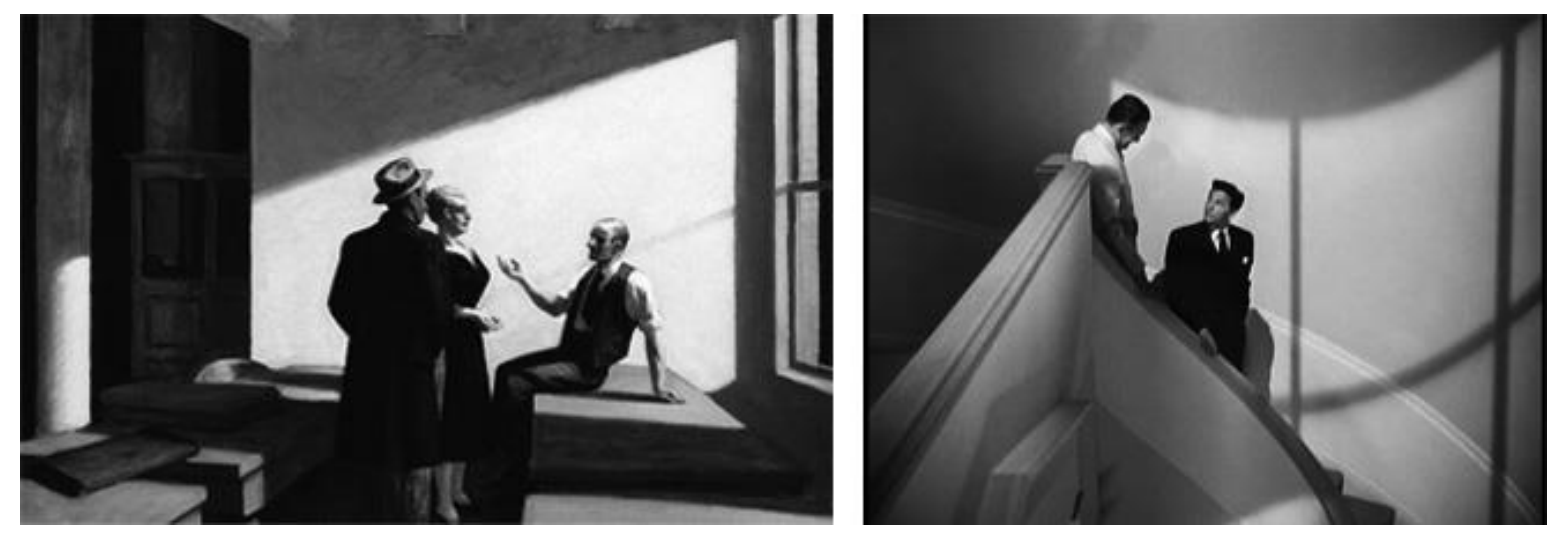

Figura 20 - Conference at night (Edward Hopper, 1949) (esq.) e o jogo de luz e sombra na escada da mansão de Tucker (dir.)

Pode-se dizer que a iluminação nessa cena de Force of Evil ultrapassa a mera função de criar uma "atmosfera" sombria, comum à narrativa noir, e ganha um caráter narrativo ao interferir no significado da ação fílmica em questão, uma vez que o efeito estético alcançado, com luzes e sombras que se harmonizam com as linhas arquitetônicas do interior da mansão de Tucker, geram um contraponto ao desequilíbrio e ao caos que compõem o plano do gângster. O domínio da utilização do som na cena segue o mesmo princípio - "quando eles [Tucker e Joe] estão descendo a escada, suas vozes estão direto no microfone, mas as pessoas estão a uma distância de uma milha. Eu usei isso o tempo todo. Era o estilo do filme"160. O diálogo que é registrado, entretanto, trata sobre a investida monopolista agressiva do capital, e de como esta poderia causar a morte de Leo.

A análise dos recursos técnicos utilizados até o momento em Force of Evil-como o uso da narração, da iluminação, e do som - nos dão indícios de experimentações executadas por Polonsky e sua equipe com o intuito de gerar uma tensão deliberada entre a forma do filme e seu conteúdo, especialmente no que diz respeito aos diálogos. Tal tensão, embora não seja utilizada em todas as passagens, surge diversas vezes ao longo da narrativa - seja de maneira mais sutil, como no caso do som na cena da mansão de Tucker, seja de modo mais evidente, como o narrador-protagonista no início do filme. A recorrência dessas experimentações e a maneira como são utilizadas em Force of Evil nos leva a crer que o princípio organizador da obra é a contraposição entre o controle estético e o descontrole do

160 Sherman, E, Rubin, M. Interview with Abraham Polonsky. In: Polonsky, A. Abraham Polonsky: interviews / edited by Andrew Dickos. Jackson: University of Mississippi Press, 2013, p. 56. 
sistema. Como resultado desse conflito, temos o envolvimento do espectador na produção de sentido dentro da obra - em outras palavras, o desajuste entre a sofisticação da forma e a barbárie social retratada pelo conteúdo do filme promove um distanciamento entre a percepção do protagonista e a do espectador, o que exige desse último uma recepção ativa, que questione o status quo. Verificaremos ao longo de nosso capítulo como se dá tal efeito em outras cenas do filme.

Apesar dessa longa sequência de apresentação de Tucker, o gângster pouco aparece no decorrer do filme. Dessa forma, ao mesmo tempo em que enfatiza os efeitos do monopólio sobre os outros personagens, Force of Evil mantém o gângster como personagem periférico, impessoal e estático. Por ser apresentado como um homem de negócios em vez de um gângster rude e grosseiro, "falta-lhe o carisma que normalmente caracteriza o vilão de uma trama"161. Segundo Polonsky, a caracterização do gângster em Force of Evil é proposital, pois "quanto mais sombrio Tucker é, mais onipresente a sensação do que ele representa" 162 . Em outras palavras, por meio da caracterização do personagem e do modo como é utilizado no filme, o diretor enfatiza aos espectadores que o real antagonista não é Tucker, mas, sim, o sistema socioeconômico. Como consequência, o espectador pode refletir sobre os efeitos dessa "força do mal" no seu próprio cotidiano. Tal estratégia, entretanto, poderia ter um efeito reverso:

\begin{abstract}
Como força antagônica em um enredo ficcional, o sistema poderia ser alienado de sua conexão com o real e tornar-se parte da ficção. Ele poderia fazer o papel tradicional do destino, do mal em geral, ou figurar uma sensação geral de inevitabilidade, descontrole ou obstrução. Em todos os casos, o impacto político do filme perderia força. ${ }^{163}$
\end{abstract}

Dentro desse raciocínio, seriam necessários elementos na narrativa que ancorassem o enredo no dia-a-dia do espectador, a fim de que lhe fosse possível reconhecer os conflitos apontados pelo filme e desenvolver uma consciência crítica. Segundo Brinckmann, há dois elementos em Force of Evil que cumprem esse papel: as locações externas em Nova Iorque, como em Wall Street ou no rio Hudson; e a loteria, com sua popularidade entre a classe

\footnotetext{
${ }^{161}$ Brinckmann, C. N. The Politics of Force of Evil: An Analysis of Abraham Polonsky's Preblacklist Film. In: Prospects. Vol. 6, October, 1981, p. 368.

162 Sherman, E, Rubin, M. Interview with Abraham Polonsky. In: Polonsky, A. Abraham Polonsky: interviews / edited by Andrew Dickos. Jackson: University of Mississippi Press, 2013, p. 58.

${ }^{163}$ Brinckmann, C. N., op. cit., p. 369.
} 
trabalhadora. ${ }^{164}$ Podemos adicionar a essa equação o vocabulário utilizado tanto nos diálogos, como na narração, pois fala-se reiteradamente em "corporações", "investimentos", “fusões", "lucros", "prejuízos", “custos", "negócios" - termos que permitem ao espectador estabelecer facilmente uma homologia estrutural entre o crime organizado e o mundo dos negócios fora da ficção.

\section{Caim, Abel, e os negócios da família Morse}

Depois de encontrar Ben Tucker e conversar com ele sobre a situação de Leo - que poderia enfartar caso sua banca quebrasse com o golpe planejado pelo gângster -, Joe vai até a banca de apostas de seu irmão para tentar convencê-lo a entrar em sociedade com Tucker. A sequência desse reencontro se inicia com Joe chegando de carro a um cenário bem diferente de Wall Street. Na primeira cena, vemos uma tomada em plano geral da rua, vista de uma das calçadas. A câmera mostra, em primeiro plano, um homem abrindo uma garrafa de refrigerante. Mais adiante na narrativa, esse mesmo personagem se apresentará para Bauer (Howland Chamberlain) - o contador de Leo Morse - como Wally (Stanley Prager), funcionário de Bill Ficco (Paul Fix), concorrente de Tucker nos tempos de contrabando de bebida. Na calçada, vemos um pequeno poste indicando um ponto de ônibus, além de uma caixa do correio.

A cena se inicia com o carro de Joe parando próximo ao ponto de ônibus; ouve-se ao fundo a trilha sonora evocando um clima de mistério; Joe desce e dispensa o motorista, enquanto confere o endereço num pedaço de papel que tem no bolso. Wally deixa a garrafa sobre uma geladeira e se aproxima de Joe. Há um corte, a trilha sonora diminui o volume e vemos, em plano americano, Wally, de costas para a câmera, pedindo fósforos emprestados para Joe. Esse último tira os fósforos do bolso, entrega a Wally e diz: "Pode ficar com eles". A câmera permanece fixa com Wally em primeiro plano, que acende um cigarro e observa Joe atravessar a rua.

\footnotetext{
164 Sherman, E, Rubin, M. Interview with Abraham Polonsky. In: Polonsky, A. Abraham Polonsky: interviews / edited by Andrew Dickos. Jackson: University of Mississippi Press, 2013, p. 58.

${ }^{164}$ Brinckmann, C. N., op. cit., p. 369.
} 
Antes de entrar por uma porta, o narrador-protagonista começa a explicar as atividades de Leo: "Há anos não via meu irmão Leo. E aqui estava ele, de volta ao cortiço onde nascemos". Nesse momento há um corte, e vemos Joe subindo uma escada. Continuamos ouvindo ao fundo a trilha sonora misturada ao barulho de máquinas e de moedas.

Ao chegar à porta do apartamento da banca de Leo, Joe é atendido por Bauer primeiramente por uma fresta na porta. Assim que Joe entra, vemos um plano geral do interior do recinto, e o ruído das máquinas e moedas aumenta. Embora a visita seja feita durante o dia, todas as janelas estão cobertas por persianas, a fim de evitar que se observe de fora o que acontece no apartamento. $\mathrm{O}$ ambiente, dessa forma, é escuro, iluminado apenas por alguns lustres que descem do teto. A profundidade de campo nos permite observar com nitidez, além de Joe, outras onze pessoas em cena, entre homens e mulheres. Joe aparece no quadro em segundo plano, à esquerda. Em primeiro plano estão dois funcionários separando moedas em sacos com uma máquina, e outro trabalhando numa máquina de calcular. Ao fundo, é possível ver, enquadrada por uma pequena janela, a secretária de Leo, Doris Lowry (Beatrice Pearson), sentada em outra sala enquanto atende um cliente. A voz do narrador, então, se sobrepõe ao ruído do ambiente: “As bancas ficavam atrás de salas de bilhar, armazéns, adegas ou escondidas nos apartamentos de cortiços, como o do Leo". (Figura 21)

Após um corte, o diretor nos mostra um plano de detalhe dos instrumentos de trabalho dos funcionários de Leo - a máquina de calcular e a que separa as moedas. Em voz-over um dos funcionários diz: "Grande aposta no 776 hoje”. Temos um corte e vemos um plano médio enquadrando Joe, o cliente da banca, Bauer, um dos funcionários sentado à mesa de costas e Doris sentada ao fundo. O cliente da banca vira-se para o funcionário e diz: "As pessoas têm a superstição de jogar todo 4 de julho. O velho número da liberdade. Nunca sai”. Enquanto o cliente conversa com o funcionário, Joe começa a se dirigir à sala de Leo. Doris, que até o momento não havia percebido a presença de Joe, imediatamente é atraída por ele, e o olhar dela acompanha os passos de Joe pelo corredor, ignorando o cliente que tenta falar com a secretária. (Figura 22)

Se na conversa com Tucker na sequência anterior Joe demonstra estar preocupado com seu irmão, uma vez que esse poderia morrer caso falisse junto com as outras bancas, o início da sequência que marca o reencontro dos irmãos demonstra uma ambiguidade de caráter do protagonista. Embora sua preocupação fraternal pareça autêntica, o narrador nos 
revela que "não vê seu irmão há anos", o que deixa claro que sua visita só foi feita porque era extremamente necessária.

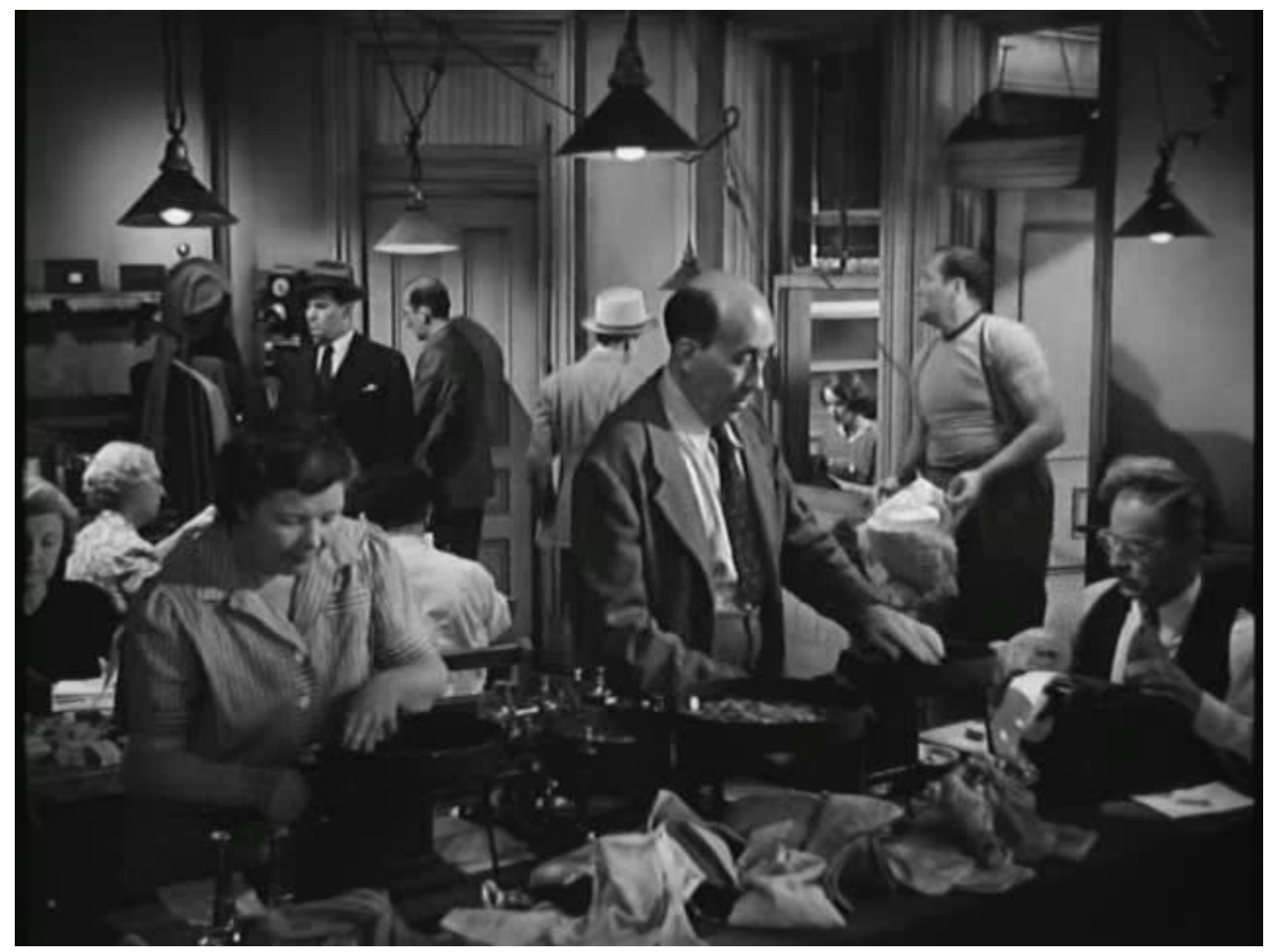

Figura 21 - A banca de Leo Morse

O diretor também nos apresenta, na cena inicial dessa sequência, Wally, um personagem cujo nome só nos será apresentado mais adiante no filme. Wally aparece de maneira ainda mais discreta diversas vezes durante a narrativa nas mais variadas situações, como um observador dos acontecimentos que reforça a onipresença do crime organizado em Force of Evil. Ao nos apresentar esse personagem dessa maneira e colocá-lo em cena de forma discreta em outros momentos do filme, Polonsky também propõe ao espectador que ele esteja atento tanto às ações centrais da cena, praticadas pelos protagonistas, quanto às periféricas ou que ocorrem em segundo plano, uma vez que todas têm a sua devida importância dentro da narrativa e ajudam a entendê-la. Esse procedimento é recorrente no filme, e pode ser realizado de diversas maneiras: por meio da montagem, da escolha de um 
determinado enquadramento ou movimento de câmera, e também pela direção dos atores. A cena em que Doris acompanha os passos de Joe é um bom exemplo desse recurso.

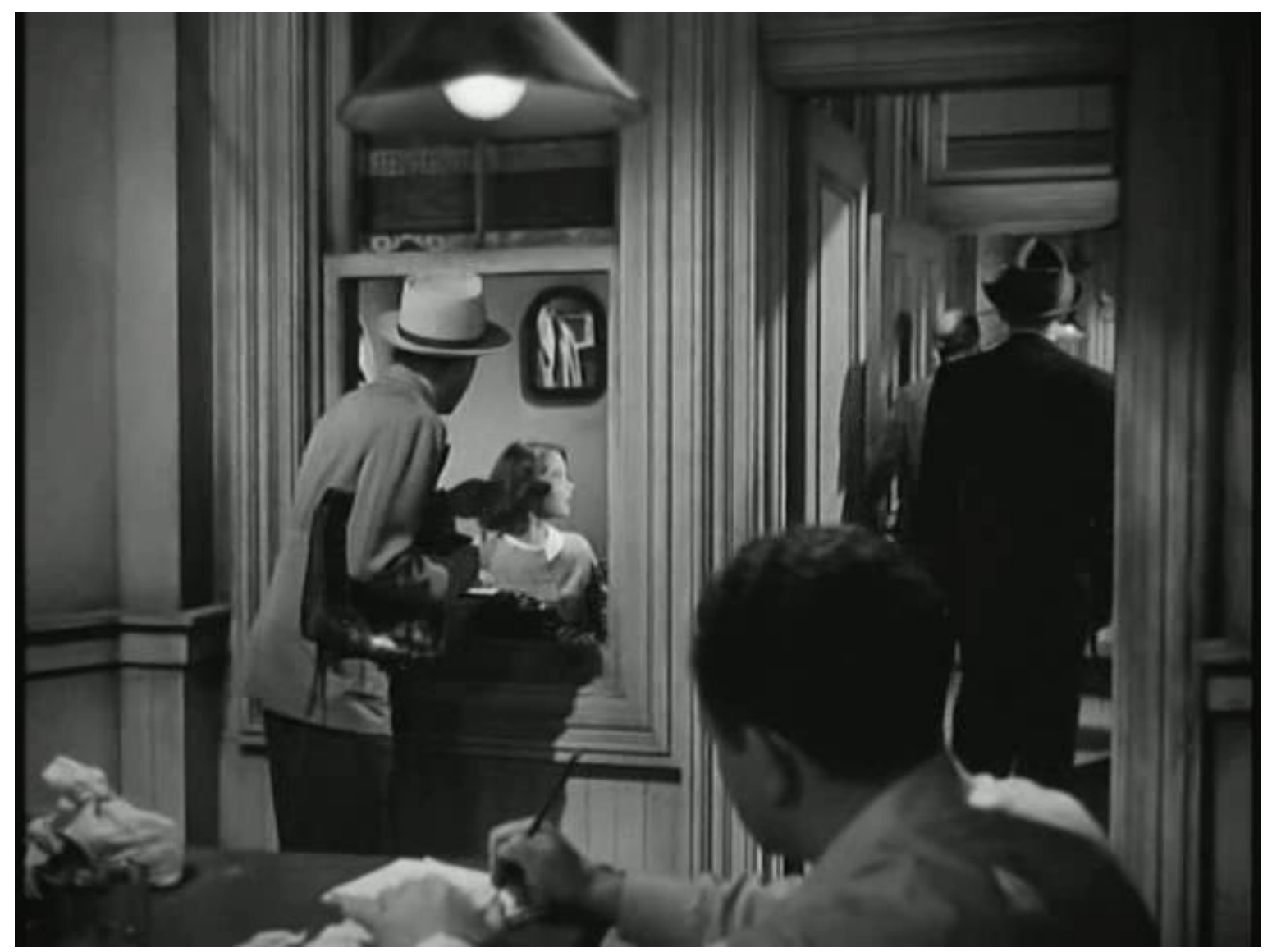

Figura 22 - Doris observa Joe e ignora o cliente

No momento em que Joe entra pela porta do apartamento, Polonsky nos apresenta o primeiro aposento em um plano geral em câmera estática (Figura 21). O acompanhamento da sequência de planos que mostram Joe chegando ao bairro e subindo as escadas do prédio faz o espectador concentrar sua atenção no protagonista. No entanto, nesse plano geral em questão, embora a quantidade de informações apresentada de uma só vez seja grande, o espectador é convidado a estabelecer relações entre os elementos apresentados por meio de três recursos técnicos utilizados simultaneamente: em primeiro lugar, a montagem, que oferece a esse plano específico tempo suficiente para a observação de toda a cena; em segundo lugar, a narração, que descreve e explica o funcionamento de bancas de apostas como as de Leo; e, em terceiro lugar, a profundidade de campo, que dá nitidez ao plano como um todo. 
Pode-se dizer, dessa forma, que estamos novamente diante de um procedimento diverso do drama tradicional, o qual prioriza relações focadas no indivíduo e o andamento acelerado da narrativa em nome da ação, implicando em uma perda do ponto de vista da exposição dos conteúdos. Em outras palavras, ao priorizar a aceleração do ritmo, o drama só oferece ao espectador conteúdos que lhe são imediatamente apreensíveis e a relação desses com o que ocorre subsequentemente. A soma dos recursos técnicos empregados no primeiro registro do interior da banca de apostas de Leo promove uma quebra nesse ritmo do drama, aproximando-o do caráter expositivo do épico, em que o espectador é levado a estabelecer conexões entre os elementos em cena, mas precisa de tempo hábil para tal reflexão. De certa maneira, parte dos recursos técnicos empregados por Polonsky em Force of Evil, como a utilização da profundidade de campo com a finalidade de estabelecer relações de conjunto e a composição inusitada de alguns planos, estabelece relações com procedimentos que Orson Welles havia implementado em Citizen Kane (1941) no âmbito da encenação épica.

O que primeiro nos chama a atenção na composição da cena é a informalidade do trabalho: a organização é precária e há muitas pessoas trabalhando em diferentes atividades num ambiente relativamente pequeno. As máquinas de contar moedas - cujo ruído acompanha a cena o tempo todo, mesmo quando a voz do narrador a sobrepõe - são manuais e operadas por um homem e uma mulher. A mais jovem do grupo é Doris, que aparece na cena em segundo plano.

O tempo que Polonsky dedica a essa cena e a descrição feita pelo narrador destacam o processo do trabalho, mesmo que clandestino. Tal procedimento fica ainda mais evidente quando, na cena seguinte, o diretor nos mostra um plano de detalhe de duas ferramentas de trabalho essenciais dos funcionários de Leo: a máquina de calcular e a de contar moedas. $\mathrm{O}$ registro de grupos de trabalhadores em seu ambiente de trabalho coletivo leva, em Force of Evil, a uma reflexão incomum dentro do cinema hollywoodiano sobre os processos produtivos. Em vez de concentrar a narrativa somente em seus protagonistas, Polonsky direciona o olhar dos espectadores nessa cena para os trabalhadores e chama a atenção para o fato de que eles estão envolvidos de alguma forma na narrativa.

Vale notar a presença do dinheiro nessa e em outras sequências desde o início do filme: ele está no discurso do narrador na cena de abertura, nas mãos dos apostadores na banca de jornal, no cofre que Joe abre dentro de seu escritório, nas mãos de Tucker e, agora, nos instrumentos de trabalho dos funcionários de Leo. A diferença entre uma referência e outra ao dinheiro é justamente a quantidade: enquanto Leo e Tucker conversam em termos 
de milhões de dólares, os trabalhadores só lidam com centavos. A própria iluminação desigual do ambiente, feita por poucos lustres baratos, denotam uma distinção de classe quando comparados com os outros ambientes frequentados por Garfield, como a casa de Tucker na reunião com Taylor, que tem iluminação mais bem distribuída feita por lustres maiores. (Figura 18).

Por último, chama-nos a atenção nesse trecho descrito o interesse de Doris por Joe. Há várias ações concomitantes na cena: o cliente da banca conversa com um dos funcionários, comentando sobre a superstição com o número 776; ao fundo, Bauer abre a porta da sala de Leo; Joe, por sua vez, anda em direção a Bauer; enquanto isso, o ruído das moedas permanece constante. Mesmo com todas essas distrações visuais e sonoras para o espectador - e embora seja possível ver Doris somente do busto para cima através de uma janela -, a duração prolongada do plano e a profundidade de campo da cena nos permite acompanhar todas as ações simultâneas e perceber o movimento de Doris, que não é nada discreto (Figura 22). A atração de Doris por Joe é um dado importante para o espectador porque, a partir dele, é possível compreender melhor as ações da personagem ao longo da narrativa. Poderemos observar outras atitudes de Doris no prosseguimento da nossa descrição.

Bauer anuncia a Leo que seu irmão quer vê-lo. Há um corte, e vemos Leo pela primeira vez, em um plano médio de seu escritório. O personagem está sentado à sua mesa em um canto da sala, mastigando um sanduíche enquanto trabalha. A mesa é rústica, e o seu material de trabalho se mistura aos guardanapos. Leo é gordo e tem o cabelo desgrenhado; ele veste camisa branca, colete e uma gravata no colarinho mal engomado. O ambiente é ainda mais escuro que os outros do escritório - somente um lustre ilumina a mesa de Leo. “Meu irmão?", pergunta Leo, estranhando a presença de Joe no escritório. "Como ele é?". "Como fogos de artifício, seu bobo", Joe responde, de maneira jocosa, entrando na sala e fechando a porta atrás de si, deixando Bauer para fora. A câmera o mostra em plano médio, destacando seu sorriso e a elegância de seu terno escuro. Joe se aproxima de Leo, joga o chapéu sobre a mesa e senta-se de maneira desleixada sobre ela. Tem início então o diálogo entre os dois mostrado em campo e contracampo, e em planos médios dos dois personagens:

Joe: Como vai, Leo?

Leo: O que você quer, Joe?

Joe: Vim te ver, Leo. Preciso de um motivo especial?

Leo: Não viria aqui se não tivesse motivo especial. 
Joe: Que diferença faz? Somos irmãos.

Leo [para de trabalhar e olha para Joe]: É visita social ou de negócios? Não te vejo há séculos. [impaciente] O que é, estou ocupado.

Joe: Leo... [faz uma pequena pausa e levanta-se da mesa] Vou te tirar dessa espelunca e te colocar num escritório de verdade, com negócios de verdade. Para retribuir por tudo, porque você é meu irmão mais velho. Por isso eu vim.

Leo [pega um lenço amarrotado e seca o suor do rosto]: Volte quando eu estiver morto.

Joe [aumentando o tom de voz]: Briguei para chegar nessa proposta, arrisquei o pescoço. [De maneira ríspida] Agora escute! Algo muito sério vai acontecer com seu negócio. A sua é uma das 20 ou 30 bancas da cidade. Uma das menores. [começa a caminhar para perto das janelas com as mãos na cintura - a câmera mostra o rosto de Leo em primeiro plano à direita e Joe à esquerda, ao fundo] Suponha que uma sociedade apareça. Suponha que ela organize e mescle essas bancas, eliminando as menores como a sua. Agora está me escutando, não é? [Joe começa a se aproximar de Leo, apoiando os braços na mesa] Suponha que reduzam gastos gerais, legais, fianças, diminuindo os custos para garantir os lucros. Um homem como você estaria fora do ramo. Não poderia competir, certo? Mas suponha que você tem um irmão. Que faz sua banca ser a primeira na fusão, na companhia, na corporação.

Leo: Qual corporação? Tucker? [alguém bate à porta] Entre!

Nesse instante, Doris abre a porta e entra na sala segurando um copo de leite e alguns bilhetes. Ela primeiro sorri e acena discretamente com a cabeça para Leo, mas, logo em seguida, volta seus olhos para Joe. "Estou com os bilhetes ganhadores, Sr. Morse", ela diz, enquanto se aproxima da mesa e deixa o copo e os bilhetes sobre ela - sem tirar os olhos de Joe, que não demonstra qualquer interesse em Doris. O diálogo entre Joe e Leo prossegue, enquanto Doris se dirige a um cofre no chão, próximo à parede.

Leo: E o que essa corporação espera de mim, irmão Joe?

Leo: Em troca da organização... [Joe hesita e olha para Doris]

Joe: Não guardo segredos da Doris. Se quiser falar, fale. Ou saia.

Joe: Em troca da organização dos serviços e em troca da sua entrada, ela fica com dois terços dos lucros e você com um terço. Por outro lado...

Leo [interrompendo Joe]: Dois terços pro Tucker, irmão Joe, e um terço pro meu negócio? [Joe se afasta da mesa] Sabe o que é isso, Joe? [levantando a voz] Chantagem! [Joe e Doris viram-se assustados para Leo] Isso que é, chantagem! [dirigindo-se a Doris] Meu próprio irmão me chantageando! 


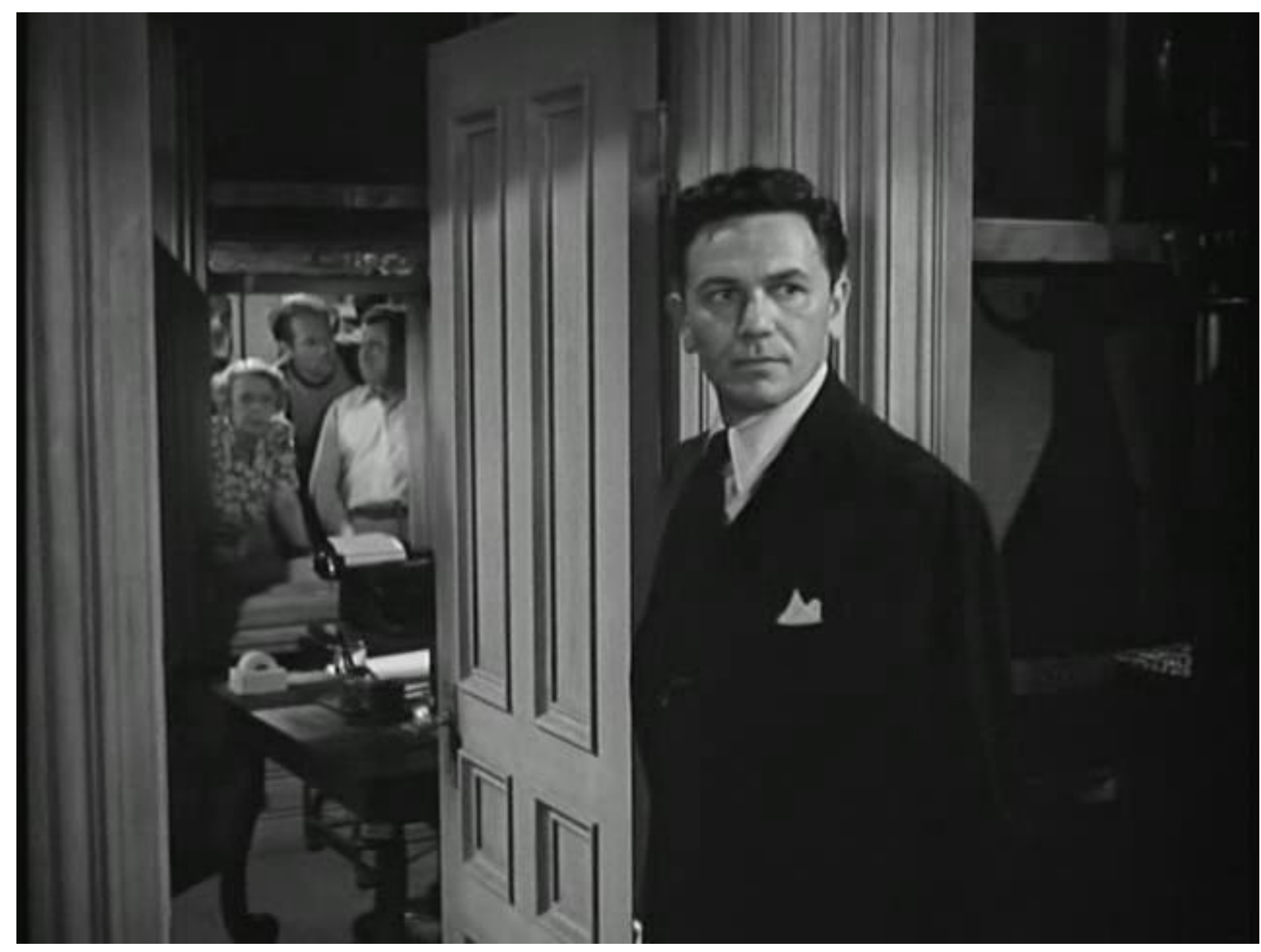

Figura 23 - Os funcionários de Leo acompanham a discussão

Joe [andando de volta para a mesa e batendo com a mão nela]: Está louco! Totalmente louco! Não está me escutando!

Leo: Não quero!

Joe: Sabe por que não quer? Digo por que: porque é um homem pequeno! Para as coisas pequenas você é um tigre. Um tigre! [Leo, transtornado, coloca a mão no peito e toma um gole do copo de leite] Mas se é algo grande você grita, esperneia e xinga. [De maneira jocosa] "Oh, não, um milhão de dólares para o Leo? Deve ser endereço errado, deve ser para o vizinho".

Leo [levantando-se da mesa, dirigindo-se à porta; ao mesmo tempo, Doris também se levanta com alguns maços de dinheiro na mão e para ao lado de Joe]: A resposta é não!

Joe: Você entende que a sua resposta não impede a fusão das bancas, inclusive a sua? [Leo está prestes a abrir a porta, mas Joe o interrompe, pegando em seu braço] Leo, está é sua chance. Eu a consegui pra você.

Leo: Pegue sua chance, Joe, e saia daqui. Sou um homem honesto e não um gângster como o Tucker! 
Nesse momento, Leo abre a porta da sala e volta para sua mesa. A câmera filma em plano americano Joe em pé, parado, observando Leo que já saiu do enquadramento. Em segundo plano, ao fundo, a porta aberta revela quatro funcionários de Joe acompanhando o que acontece na sala de Leo. (Figura 23)

Joe olha para a direita do enquadramento na direção de Leo e pergunta: "Está dizendo para mim, um advogado corporativo, que você tem um negócio legal aqui?”. Joe volta-se para os funcionários ao fundo, fecha a porta e continua a discussão, de maneira ríspida: "Do que chama isso? Pagamentos por jogatina, esquema de apostas ilegais? Violação do artigo 974 do código penal. Jogo de azar!’. Há um corte e vemos Leo atrás da mesa com Doris ao seu lado, segurando os maços de dinheiro no peito, olhando assustada para Joe. "Faço meus negócios de maneira honesta e respeitável". Com outro corte, o diretor nos mostra Joe, acompanhando-o em pan shot em direção aos dois, até enquadrar os três personagens novamente em plano médio. (Figura 24)

Enquanto caminha, Joe diz, de maneira irônica:

Joe: Honesta e respeitável? [apoia as mãos sobre a mesa; Doris olha para Leo incrédula] Você não pega os cinco, dez centavos de apostadores como qualquer safado, grande ou pequeno, nesse esquema? Chamam isso de "apólice" porque jogam os centavos no jogo em vez de gastar em algo importante como apólice de seguros. É por isso! Tucker quer fazer milhões, você quer fazer milhares e você [dirige-se a Doris; ela olha, assustada] faz por 35 dólares por semana [Doris larga o dinheiro sobre a mesa, envergonhada]. Tudo a mesma coisa.

Leo: Essa é minha secretária, minha estenógrafa. [Doris, hesitante, sai de perto da mesa e volta para o cofre] Minha amiga Doris Lowry! Está comigo há muito tempo e é como uma filha para mim. E você... Eu queria ser advogado e poderia ter sido, se tivesse te mandado pra rua quando nossos pais morreram. Mas não... Trabalhei como um idiota! Por você! Te dei tudo!

Joe: Por que fala assim comigo na frente de estranhos?

Leo [exaltado]: Ela não é estranha! O estranho é você! [saindo da mesa, indo pegar seu paletó ao lado da porta; a câmera o acompanha em pan shot] E vou dizer a todo mundo porque é meu irmão. Devo isso ao mundo pelo que você é. Um safado, um enganador e um gângster!

Joe [indo em direção a Leo, que está de costas]: Leo, se acalme... Tucker vai te fazer honesto e respeitável. Ele está me dando 250 mil para legalizarmos o jogo de uma vez, como o bingo, a loteria irlandesa. Vou te pagar de volta, Leo. Vou te fazer rico. Com um escritório em Wall Street, lá nas nuvens! [Joe ajuda Leo a vestir o paletó] Acalme-se, Leo. Seja razoável. 
Leo [exaltado, virando-se pra Joe, que permanece impassível]: Tudo bem! Eu sou razoável. Estou calmo. Dou-lhe minha resposta final e sensata: Minha resposta final é finalmente "não". Absolutamente e finalmente não! Positivamente não! [gritando] Não, não, não! E não! [sai pela porta]

Essa sequência de reencontro de Joe e Leo estabelece para o espectador, além das diferenças entre os irmãos, o tipo de relacionamento que existe entre os dois, e problematiza tal relação em vários níveis. O que se nota primeiramente é que, embora se porte com desenvoltura no escritório de seu irmão, Joe não pertence àquele ambiente - bem diferente do seu escritório em Wall Street. A precariedade das instalações da sala de Leo forma um contraste com o escritório de Joe, que possui uma grande mesa de madeira trabalhada, além de bancos e sofás revestidos de couro e quadros pendurados na parede.

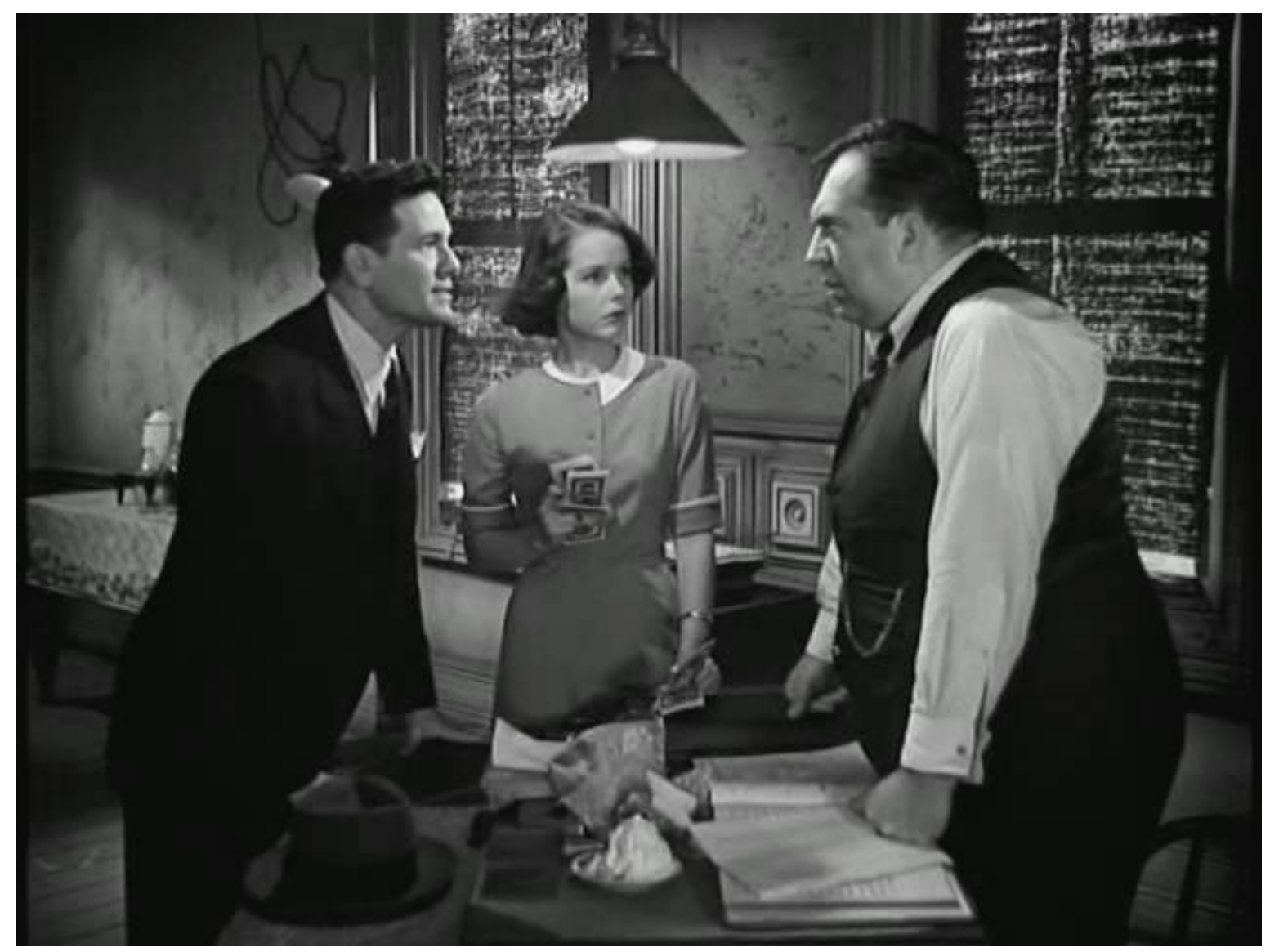

Figura 24 - Joe, Doris e Leo 
Em segundo lugar, a recepção nada amigável de Leo revela um conflito posto de antemão. "É visita social ou de negócios?", ele pergunta, e estabelece logo no início da conversa uma antítese entre negócios e as relações pessoais. Leo sabe que não há possibilidade de coexistência harmônica entre esses dois universos e não espera de Joe qualquer tipo de atitude fraternal - nem como irmãos de sangue e muito menos como irmãos de classe. Joe, por sua vez, antes mesmo de apresentar sua proposta, justifica sua ação pelos laços familiares. O espectador sabe, pelo diálogo anterior dele com Tucker, que o remorso de ver seu irmão arruinado - morto, talvez - devido a uma ação planejada sua é o que o faz ir até o escritório de Leo. Estabelece-se, dessa maneira, uma relação incongruente entre negócios, dinheiro e família que é explorada ao longo do filme.

A conversa entre os irmãos é interrompida por Doris momentos antes de Joe apresentar os termos da oferta de Tucker a Leo. Doris vê Leo acusar Joe de chantagem, recusar a proposta e exaltar a própria honestidade, além de chamar seu irmão de gângster. De acordo com o crítico Jack Shadoian,

\begin{abstract}
ambos [Joe e Leo] são corruptos, embora Leo afirme ter seus valores morais, que são progressivamente minados com o decorrer do filme. Eles se amam como irmãos e cada um insiste que aquilo que fizeram ou fazem é em benefício do outro. O conflito prossegue, filosófica e emocionalmente. Joe busca aliviar sua culpa tentando fazer com que Leo enriqueça. As recusas insistentes de Leo têm um toque de perversidade. Ele também é culpado, invejoso. Em última instância, ele é mais cego que Joe, e não é mais moralmente correto que seu irmão. ${ }^{165}$
\end{abstract}

A figura 23 mostra os funcionários de Leo, que haviam parado de trabalhar e acompanham atentamente a discussão. A escolha do enquadramento e a profundidade de campo permitiram ao diretor mostrar tanto a ação principal, com Joe em primeiro plano, como os trabalhadores em segundo plano, emoldurados pela porta e pela janela. Joe fecha a porta para isolá-los da conversa, assim como fez com o engraxate Louie quando precisava de privacidade ao conversar com Hobe, seu sócio no escritório de advocacia. Essas atitudes de Joe estabelecem um limite bem definido entre os trabalhadores braçais e ele próprio quando se trata de negócios. A única com quem Joe estabelecerá alguma relação é Doris, mas os interesses nesse caso serão amorosos.

${ }^{165}$ Shadoian, J. Dreams and Dead Ends: The american gangster film. New York: Oxford University Press, 2003, p 121. 
Leo afirma a Joe que mantém seus negócios de maneira "honesta e respeitável". Em última instância, o primeiro "afirma com convicção, embora de maneira irracional, que ladrões menores são mais honestos que os grandes"166. A figura 24 mostra o momento em que Joe começa a argumentar com seu irmão, revelando a Doris uma realidade sobre o trabalho com o jogo de azar que ela, a julgar pela sua reação, não tinha consciência. O plano médio registra visualmente posições que se confrontam e se debatem, mesmo estando ambas no âmbito da ilegalidade. Para Shadoian,

\footnotetext{
eles [Joe e Leo] não conseguem enxergar que fazem as mesmas coisas, são unidos tanto pelo amor quanto pela corrupção. E não conseguem enxergar porque, seguindo os caminhos do mundo, suas naturezas e seus verdadeiros conhecimentos das coisas foram deformados. Polonsky está falando sobre o que viver no sistema econômico americano faz com as pessoas, Leo e Joe e todos os outros. ${ }^{167}$
}

O discurso de Joe acaba com o "mito da pureza do pequeno negócio e mostra como aquela forma de capitalismo já está imbuída em valores da grande corporação" ${ }^{\text {168 }}$. Ainda na figura 24 é possível ver Doris, ao centro, com os maços de dólares nas mãos, confusa a respeito de qual lado da mesa deve ficar. Quando Joe revela a Doris que ela também faz parte de um negócio ilegal, ela larga o dinheiro, num gesto de repúdio ao que ele representa. Joe demonstra um nível de racionalidade e clareza que confude Doris. Ao trazer à tona sua mágoa com Joe, Leo diz que Doris é muito mais da sua família do que o próprio irmão. Dessa forma, Leo sustenta o mito do pequeno negócio como "familiar", fazendo do laço afetivo um antídoto ao trabalho alienado.

Vale ressaltar também nessa sequência o próprio diálogo entre Joe e Leo, que permite ao espectador identificar rapidamente as características da personalidade de cada um dos irmãos logo na primeira vez em que contracenam. Para o crítico William S. Pechter, o maior feito de Force of Evil é "o modo como as palavras trabalham com as imagens. Nada é redundante ou desnecessário"169. Segundo Pechter,

\footnotetext{
${ }^{166}$ Buhle, P., Wagner, D. The politics and mythology of film art: Polonsky's noir era. In: A very dangerous citizen: Abraham Polonsky and the Hollywood Left. Berkeley and Los Angeles: University of California Press, 2001, p. 120.

${ }^{167}$ Shadoian, J. Dreams and Dead Ends: The american gangster film. New York: Oxford University Press, 2003, p 121.

168 Broe, D. Film Noir, American Workers, and Postwar Hollywood. Gainesville: University Press of Florida, 2009, location 1382 (Kindle Edition).

${ }^{169}$ Pechter, W. S. Conversations with Abraham Polonsky/1962\&1968. In: Polonsky, A. Abraham Polonsky: interviews / edited by Andrew Dickos. Jackson: University of Mississippi Press, 2013, p. 36.
} 
[a]o longo do filme, o protagonista comenta constantemente sobre a ação, dizendonos não só o que ele e outros estão pensando, mas descrevendo acontecimentos mesmo enquanto os acompanhamos na tela; (...) o efeito estético de todas as repetições oblíquas do filme, com sua linguagem sobrepondo a imagem e a linguagem sobrepondo a linguagem, é transmitir uma ressonância quase musical para a luta entre os irmãos, que está no núcleo do filme. (...) A linguagem se torna um tipo de presença constante, e as imagens se movem de forma congruente ou dissonante com uma extraordinária autonomia e liberdade. ${ }^{170}$

O comentário de Pechter corrobora nossas observações feitas até o momento sobre o método de trabalho de Polonsky e sua equipe. Conforme apontamos nas cenas analisadas até o momento, é possível verificar a configuração de congruências e dissonâncias no emprego dos recursos cinematográficos e estabelecer contrapontos entre o controle sobre esses procedimentos técnicos e o caos do sistema econômico em que se desenrola a narrativa. No caso específico desse diálogo entre os irmãos Morse, o que nos chama a atenção é o domínio sobre os materiais trabalhados que o diretor precisa demonstrar nessa sequência para que ela cumpra, pelo menos, três funções simultâneas: demonstrar o conflito entre Joe e Leo, registrar as reações tanto de Doris como dos funcionários da banca, e explicar as operações e consequências das loterias ilegais - tudo de modo apreensível ao espectador em um determinado tempo. O que se vê como resultado é uma negociação entre dois caráteres distintos do diálogo: o dramático, que preza pela manutenção do ritmo da narrativa, e o épico, que procura aprofundar os conhecimentos do espectador sobre o assunto tratado em cena.

Além de ser fundamental para o entendimento da relação complexa entre Joe e Leo, essa sequência também nos serve como modelo para o tipo de relacionamento que se estabelece entre outros personagens. Em Force of Evil, a vida social é vista como um conflito generalizado, uma vez que há traições em todos os níveis: Joe trai Leo em nome do dinheiro; Leo também é traído por Bauer, seu funcionário, que o entrega para o gângster Joe Ficco; Ficco, por sua vez, assassina Leo e rompe o acordo feito previamente com Ben Tucker; esse último é traído por Edna, sua esposa, que tenta seduzir Joe; o advogado também trai Tucker ao fazer a conversa entre eles, na qual o gângster revela todo o esquema ilegal da fusão das bancas, ser ouvida pela polícia por meio do grampo telefônico autorizado pelo promotor Hall.

\footnotetext{
${ }^{170}$ Pechter, W. S. Conversations with Abraham Polonsky/1962\&1968. In: Polonsky, A. Abraham Polonsky:
} interviews / edited by Andrew Dickos. Jackson: University of Mississippi Press, 2013, p. 36. 
Tal conflito também se dá no âmbito dos princípios individuais, no caso de Leo. Em outro momento da narrativa, após a falência das bancas com o número 776 saindo na loteria, Joe vai até a casa de Leo para "limpar sua consciência" e tentar convencê-lo novamente a aceitar a oferta de Tucker. Sylvia, esposa de Leo, não quer que ele ouça qualquer proposta de Joe, pois, de acordo com ela, Joe é um ladrão, e "conselho de ladrão nunca é bom":

Sylvia: Não se envolva com ele, Leo. Você é um homem de negócios.

Leo: Sim, fui um homem de negócios minha vida inteira e, honestamente, eu não sei o que é um negócio.

Sylvia: Bem, você teve uma oficina mecânica, você teve uma imobiliária.

Leo: Você acha que sabe alguma coisa. Sim, uma imobiliária. Vivendo de hipoteca em hipoteca, roubando crédito como um ladrão. E a oficina - aquilo era um negócio! Três centavos a mais para cada galão de gasolina, dois para o chofer, e um centavo para mim. Um centavo para um ladrão, dois centavos para o outro. Agora com Joe aqui não vou mais precisar roubar centavos. Vou ter grandes bandidos pra roubar dólares pra mim.

Além do diálogo de Leo com Sylvia servir para reforçar a linha tênue que separa os negócios legais dos ilegais - tema do filme desde o seu início -, ele também nos revela que, se antes Leo acreditava ter uma determinada correção moral que o colocava acima de Joe, a visita do irmão o fez rever seus conceitos e desfazer as ilusões de honestidade nos seus negócios.

Dentro do gênero gângster em Hollywood, a utilização do relacionamento familiar para estabelecer conflitos dentro da narrativa não é novidade. The Public Enemy (William A. Wellman, 1931) já havia mostrado Tom Powers (James Cagney) seguir o caminho do crime enquanto seu irmão Mike (Donald Cook) volta da Primeira Guerra Mundial para trabalhar honestamente e questionar a origem do dinheiro de Tom. Manhattan Melodrama (W.S. Van Dyke, 1934) eleva esse conflito a outro patamar ao construir o dilema entre o gângster Blackie Gallagher (Clark Gable) e seu irmão Jim Wade (William Powell), cujo trabalho como procurador do Estado de Nova Iorque o obriga a condenar Blackie à cadeira elétrica. Quatro décadas mais tarde, O Poderoso Chefão (Francis Ford Coppola, 1972) retoma o tema e amplia o núcleo dos irmãos para toda a família envolvida com o crime organizado. De acordo com o crítico Fredric Jameson, no filme de Coppola a família pode ser 
vista como uma figura de coletividade e como um objeto de desejo utópico, quando não de inveja utópica. Uma síntese narrativa como O Poderoso Chefão é possível apenas numa conjunção em que o conteúdo étnico - a referência a uma coletividade estrangeira - aparece para preencher os antigos esquemas de gângster e para infleti-los poderosamente na direção do social; (...) Nos Estados Unidos, com efeito, os grupos étnicos não são apenas objeto de preconceito, são também motivo de inveja; e esses dois impulsos estão profundamente entrelaçados e se reforçam mutuamente. (...) Assim, numa época em que a desintegração das comunidades dominantes é persistentemente "explicada" em termos (profundamente ideológicos) de deterioração da família, crescimento da permissividade e perda de autoridade do pai, o grupo étnico pode aparecer como projeção de uma imagem de reintegração social, por meio da família patriarcal e autoritária do passado. Portanto, os laços estreitamente unidos da família (em ambos os sentidos) mafiosa, a segurança protetora do pai (padrinho) com sua onipresente autoridade, oferecem pretexto contemporâneo para um imaginário utópico que não pode mais expressar-se através de paradigmas e estereótipos antiquados, como a imagem da ora extinta cidadezinha americana. ${ }^{171}$

Se $O$ Poderoso Chefão permite a Jameson enxergar um componente utópico na caracterização da família Corleone, o mesmo não se pode dizer sobre a família Morse. Embora Force of Evil também trate de um grupo étnico específico - "Morse", segundo Polonsky, era um nome judeu muito comum na Inglaterra e nos Estados Unidos ${ }^{172}$-, a coletividade estrangeira não é o foco da narrativa, e o filme está longe de ser uma "imagem da reintegração social" exaltada por Jameson. Pelo contrário, as relações sociais em Force of Evil, mesmo as familiares, são mediadas pelo capital, e o filme não dá qualquer indício de que outro tipo de sociabilidade é possível. Ao mesmo tempo, o filme de Polonsky não incorre no equívoco de criminalizar uma única etnia ou classe social, como fizeram Little Caesar e outros filmes do gênero ao longo da década de 1930, porque o diretor amplia a abrangência da criminalidade para o cotidiano do cidadão comum, que faz apostas em loterias ilegais sem sofrer as consequências da contravenção.

Alguns críticos referem-se ao relacionamento entre Joe e Leo nos termos da narrativa bíblica de Caim e Abel, em que a inveja de um pelo outro provoca o fratricídio. O próprio

\footnotetext{
${ }^{171}$ Jameson, F. Marcas do Visível. Rio de Janeiro: Graal, 1995, p. 33.
}

${ }^{172}$ Schultheiss, J. Notes to the critical commentary. In: Force of Evil: The Critical Edition, by Abraham Polonsky. Northridge: The Center for Telecommunication Studies California State University, 1996, p. 193. 
filme faz referência ao mito bíblico em um dos diálogos entre Joe e Leo, na cena em que que os dois estão saindo do fórum:

Leo: Tudo o que Caim fez a Abel foi assassiná-lo.

Joe: Eu não tenho nada a ver com isso.

Leo: Sei, não teve. Mas obrigado por pagar a fiança e me soltar usando a mesma chave que usou para me prender.

Embora a traição de Caim a Abel se encaixe perfeitamente ao contexto moderno do capitalismo, o conflito entre os irmãos bíblicos não dá conta de interpretar a relação entre os irmãos Morse porque os personagens da Bíblia são planos e representam maniqueisticamente o bem e o mal, enquanto em Force of Evil os personagens são esféricos, e configuram em si características mais complexas e dinâmicas.

\begin{abstract}
Embora Joe lembre Caim em sua violência, egoísmo e irreverência, e Leo lembre de Abel sua gentileza e moral, Joe também é caracterizado como responsável, arrependido, e disposto a se regenerar, enquanto Leo é rígido, irracional, desesperado e tenta colocar a culpa em seu irmão. (...) O mito de Caim e Abel, dessa maneira, não fornece o esqueleto para o enredo porque as diferenças entre as narrativas são mais significativas do que as semelhanças. ${ }^{173}$
\end{abstract}

Polonsky usa as diferenças entre Joe e Leo e o fato de serem irmãos para mostrar a amplitude da influência do capital, capaz de corromper as relações interpessoais, inclusive as familiares. Não há em Force of Evil, dessa maneira, a configuração dos "laços estreitamente unidos da família", principalmente porque o núcleo familiar da família Morse já havia se fragmentado com a morte dos pais de Joe e Leo quando ambos ainda eram jovens. Há também o rancor de Leo por ter abdicado de seus sonhos para trabalhar e sustentar o irmão mais novo, que pôde estudar e formar-se advogado. Joe quer se redimir dessa culpa e recompensar o irmão, mas o faz forçando-o a trabalhar para Tucker contra a vontade de Leo. De certa forma, esse também se sente culpado por ter dado a Joe a educação que o levou à criminalidade - contrariando o senso comum, que diz justamente o contrário: quanto mais o indivíduo estudar, mais longe do crime estará. Segundo Polonsky, Leo recusa a ajuda do irmão porque sente prazer em fazer Joe sentir-se culpado ${ }^{174}$, mas Joe não consegue

${ }^{173}$ Brinckmann, C. N. The Politics of Force of Evil: An Analysis of Abraham Polonsky's Preblacklist Film. In: Prospects. Vol. 6, October, 1981, p. 372-373.

${ }^{174}$ Cf. Schultheiss, J. Critical commentary. In: Force of Evil: The Critical Edition, by Abraham Polonsky. Northridge: The Center for Telecommunication Studies California State University, 1996, p. 160. 
compreender essa recusa, e expressa sua indignação na sequência em que leva Doris de carona do fórum para casa.

\section{Doris e a mercadoria}

A sequência se inicia com Joe e Doris sentados no banco traseiro de um carro, e a câmera filma os dois personagens em close, bem próximos um do outro. Doris começa a cena segurando o braço de Joe, enquanto uma melodia romântica pode ser ouvida ao fundo:

Doris: Fiz faculdade de administração por 10 semanas pois minha mãe achava que me daria vantagens.

Joe: Você tem muitas vantagens, Doris.

Doris: Você também tinha. Conheço Leo desde que eu tinha 13 anos, e desde então ouço falar de você.

Joe: O que ouviu?

Doris: Oh, a história do irmão pródigo que nunca voltou para casa. O quanto Leo fez por você e o pouco que fez por você mesmo. O garoto selvagem nas ruas. $\mathrm{O}$ homem selvagem que disse que era um gato selvagem na floresta. Foi o que ouvi. Ele me manteve no emprego mesmo com os negócios ruins. Acho que é por isso que fingi acreditar no que ele fingia acreditar: que lidar com loteria não era tão ruim. Agora meu nome está registrado e minha digital está fichada na polícia, e as pessoas nunca vão esquecer. E eu vou lembrar e saber. [abaixando a cabeça com pesar] Eu vou saber.

Joe: Esqueça. Você era apenas uma telefonista que foi à delegacia, mas foi um engano [wrong number, no original]. Como é ser um engano, Srta. Lowry?

Doris: Não muito bom, Sr. Morse. Não muito bom.

Joe: Pode me culpar, todo mundo faz isso. [pequena pausa, Doris olha para Joe] Culpam mesmo. [os dois sorriem. Na cena seguinte, o carro para em frente a uma banca de flores; Joe sai do carro, pega um buquê de flores, paga o florista ("Fique com o troco", ele diz) e volta rapidamente para dentro do carro, jogando o buquê no colo de Doris, que abre um largo sorriso. Há um corte para um plano mais aberto Joe e Doris, mostrando os personagens de frente, com Joe à esquerda e Doris segurando o buquê de flores no colo à direita]

Doris: Você é um homem estranho e muito mau.

Joe: E você é doce e quer que eu seja cruel com você.

Doris: Do que está falando? 
Joe: Porque você é cruel, muito cruel.

Doris: [segurando uma flor do buquê] Por que está falando loucuras, Sr. Morse?

Joe: Por que você está implorando para eu ser cruel. [tira a flor da mão de Doris e começa a arrancar pétalas dela] Te dar uma cantada, te arrebatar, tirar essa infantilidade de você. Te dar dinheiro e pecado. Isso é crueldade de verdade [jogando a flor de volta para o buquê].

Doris: O que está querendo que eu pense? O que quer que eu pense sobre mim... e você? [entrega uma flor a Joe]

Joe: Sabe o que é crueldade? Eu colocar minha mão no bolso e tirar um rubi [imita o gesto e mostra mão fechada a Doris], um rubi de um milhão de dólares, por nada. Porque você é linda de um jeito infantil. Só porque eu queria te dar, sem querer nada em troca. Isso seria crueldade?

Doris: Você tem um?

Joe: [abrindo a mão] Não. [os dois sorriem]

Doris: Quando eu era uma garotinha, os mágicos me enganavam com aquele chapéu, capa e anel de rubi, pois eu escutava o que diziam, e eles falavam tão rápido, ao invés de olhar para o que faziam. Mas agora sou adulta e tenho ficha na polícia, graças a você, e eu sei que não é cruel dar e não querer nada de volta.

Joe: É perversão. Não percebe que não é natural? Mas batalhar muito para conseguir o que quer, é natural. Se esforçar para ter as coisas, isso é humano, é natural. Mas ter prazer em não possuir as coisas, se enganar deliberadamente, como meu irmão fez hoje, não querendo ter, não se esforçando para ter. Não vê como isso é terrível para um homem? Veja como é se odiar, odiar seu irmão. Fazêlo sentir culpado, que eu sou culpado. Só de viver e ser culpado.

No trecho final dessa sequência, Joe aproveita a oportunidade para expressar sua indignação à recusa de Leo em aceitar sua oferta, e ao prazer que Leo tem em reiterar a culpa de Joe por toda a situação. Segundo Polonsky, trata-se de um curto solilóquio de Joe, que faz mais uma autorreflexão do que se dirige à Doris nesse momento: ele "está tentando estabelecer uma conduta moral para si próprio que o permitirá sobreviver a essa situação" 175 . Dentro da lógica dessa conduta moral, o protagonista desnaturaliza o altruísmo de seu irmão - uma "expressão de decência humana que obstrui sua ascensão na escada corporativa criminosa"176 -, ao mesmo tempo em que naturaliza a ambição - "batalhar muito para conseguir o que quer, é natural”. Em suma, Joe tenta naturalizar o discurso ideológico do American Dream - mais especificamente do sonho de mobilidade social -, que o

175 Schultheiss, J. Critical Commentary. In: Force of Evil: The Critical Edition, by Abraham Polonsky. Northridge: The Center for Telecommunication Studies California State University, 1996, p. 161.

${ }^{176}$ Dickos, A. Introducion. In: Polonsky, A. Abraham Polonsky: interviews / edited by Andrew Dickos. Jackson: University of Mississippi Press, 2013, p. x. 
protagonista de Force of Evil procura contraditoriamente conciliar com a tentativa de proteger seu irmão das consequências do monopólio de Tucker.

A sequência da carona que Joe dá a Doris, no entanto, não se resume ao solilóquio de Joe. Segundo Brinckmann, os encontros entre esses personagens

\begin{abstract}
oscilam entre o romance e a desilusão, atração e repulsa, esperança e desespero. E apesar desse relacionamento ser dissonante e dinâmico a seu modo, ele serve como um contraponto suave, quase pacífico à agressividade e velocidade do enredo principal. Imagens de flores, joias, vestidos esvoaçantes e parafernália doméstica caracterizam boa parte das cenas com Doris, e sua voz pura e intensamente séria, mesmo quando fala sobre o mundo de Joe, parece vir de um lugar completamente diferente. Mas Doris não é uma personagem fraca, e sua firmeza ocorre paralelamente à imprudência enérgica de Joe, e reforça o senso de determinação que o filme transmite. ${ }^{177}$
\end{abstract}

De fato, o clima romântico dos primeiros encontros entre Joe e Doris determinam, ao menos na aparência, um contraponto à dureza dos diálogos entre Joe e Tucker ou Leo. Uma análise mais detida desses encontros, entretanto, revela como Polonsky os utiliza a fim de executar um desvelamento dessas aparências. Na cena descrita acima, por exemplo, Doris diz a Joe que fingia acreditar no que Leo fingia acreditar: "que lidar com loteria não era tão ruim". A secretária também tenta aparentar "inocência" e infantilidade, na qual boa parte dos críticos de Force of Evil acreditam ao afirmar que Joe se sente atraído justamente por essas características de Doris. Entretanto, a passagem descrita acima mostra que nem mesmo o próprio advogado crê na inocência da secretária ("E você é doce, e quer que eu seja cruel com você”.) e seu mal disfarçado interesse em Joe.

O fingimento de Leo e de Doris junta-se ao de Joe - que finge não ter nada a ver com a batida policial à banca de Leo -, ao de Bauer - que finge ser leal a Leo, mas denuncia anonimamente os negócios para a polícia -, e ao de Wheelock - que finge ajudar Joe, mas ajuda nas investigações do procurador Hall. Cada mentira e fingimento dos personagens de Force of Evil são desmontados por Polonsky ao longo da narrativa em um processo análogo à luta política contra o pensamento ideológico. Segundo a pesquisadora Laís Leni Oliveira Lima,

${ }^{177}$ Brinckmann, C. N. The Politics of Force of Evil: An Analysis of Abraham Polonsky's Preblacklist Film. In: Prospects. Vol. 6, October, 1981, p. 365. 
[é] característico do processo ideológico afirmar as constituições da realidade como ela se apresenta, vendo-a como um processo natural, não porque instaura uma ideia, mas porque o pensamento ideológico esconde a realidade material que ele produz. Nesse sentido, é preciso entender que não é no nível das ideias que isso se dá, mas no obscurecimento das relações materiais. Na medida em que o pensamento ideológico capta a realidade pela sua representação, pela sua imediaticidade, ele perpetua e dá continuidade a essa “compreensão". É assim que as divisões sociais e políticas são vistas, como um processo natural, por exemplo. Embora a realidade seja percebida como injusta, é tida como normal, natural. A ideologia (re)afirma esses modos de entender a realidade, leva os proletários a se comportarem nela, oculta as contradições da vida social, naturaliza as diferenças, mantém e afirma a realidade hegemônica. Esse modelo de "ciência" e forma de pensamento que vela, naturaliza, confirma e afirma essa realidade na sua aparência e em sua imediaticidade, não poderiam ser chamados de pensamento científico, e sim, de pensamento ideológico, visto que a ideologia não capta a essência, mas a aparência. Ela não apreende a historicidade e os nexos constitutivos dos objetos, ao contrário é seu objetivo principal, escondê-los. ${ }^{178}$

O próprio registro do crime organizado como regra, e não como exceção dentro do capitalismo, reforça o posicionamento de Force of Evil contra a imediaticidade das aparências, e a busca de Polonsky por um modelo de cinema contra-hegemônico, que revele as contradições da vida social. A forma como o diálogo entre Joe e Doris é registrada contribui para essa discussão: a proximidade dos personagens no banco traseiro do carro, a troca de olhares entre ambos, a música extradiegética, e a poesia do diálogo criam uma aparência de romance, que entra em contraposição com a sua essência - o questionamento das ações criminosas de Joe, uma vez que o encontro dele com Doris só ocorre porque ela foi fichada após o advogado ter denunciado o próprio irmão à polícia.

Ao contar a Joe a respeito de seu próprio fingimento, Doris imediatamente demonstra sua preocupação com um outro tipo de aparência: “Agora meu nome está registrado e minha digital está fichada na polícia, e as pessoas nunca vão esquecer”. A personagem fala com pesar, preocupada com sua reputação perante a sociedade. Tratamos sobre esse tipo de cuidado com as aparências no primeiro capítulo, no qual analisamos o fascínio que Rico, o protagonista de Little Caesar, nutre pela própria aparência. Em última análise, tanto Rico como Doris demonstram a mesma preocupação com o julgamento alheio, mas com objetivos

${ }^{178}$ Lima, L. L. O. Aparência e Essência: da Alienação ao Fetiche. In: Itinerarius Reflectionis. Vol II, nº 5 , jul-dez 2008, p. 8-9. 
distintos: enquanto o primeiro, mais do que ser um vencedor, quer parecer um vencedor, Doris sabe que sua ficha na polícia prejudica sua imagem como trabalhadora honesta e diminui as possibilidades de vender sua força de trabalho - Leo sabe disso e pede a Joe, ainda na saída do tribunal, que ajude Doris a conseguir um emprego:

Leo: A garota, Doris. Ela precisa de ajuda. Ela pediu demissão logo antes da batida policial que você enviou à minha banca. E agora, como todos nós, tem um processo de contravenção e uma fiança. Ela perdeu as referências e é culpa sua. Você tem amigos chiques em Wall Street, e ela é boa secretária. Arranje um emprego para ela. Eu te agradeço. Por ela, não por mim.

Outro ponto importante dessa sequência é a associação entre as mercadorias e o flerte. Joe dá um buquê de flores a Doris e finge dar à moça um "rubi de um milhão de dólares, por nada". Doris aceita o primeiro com um largo sorriso, assim como dá a entender que receberia de muito bom grado o segundo, se não fosse mero fingimento.
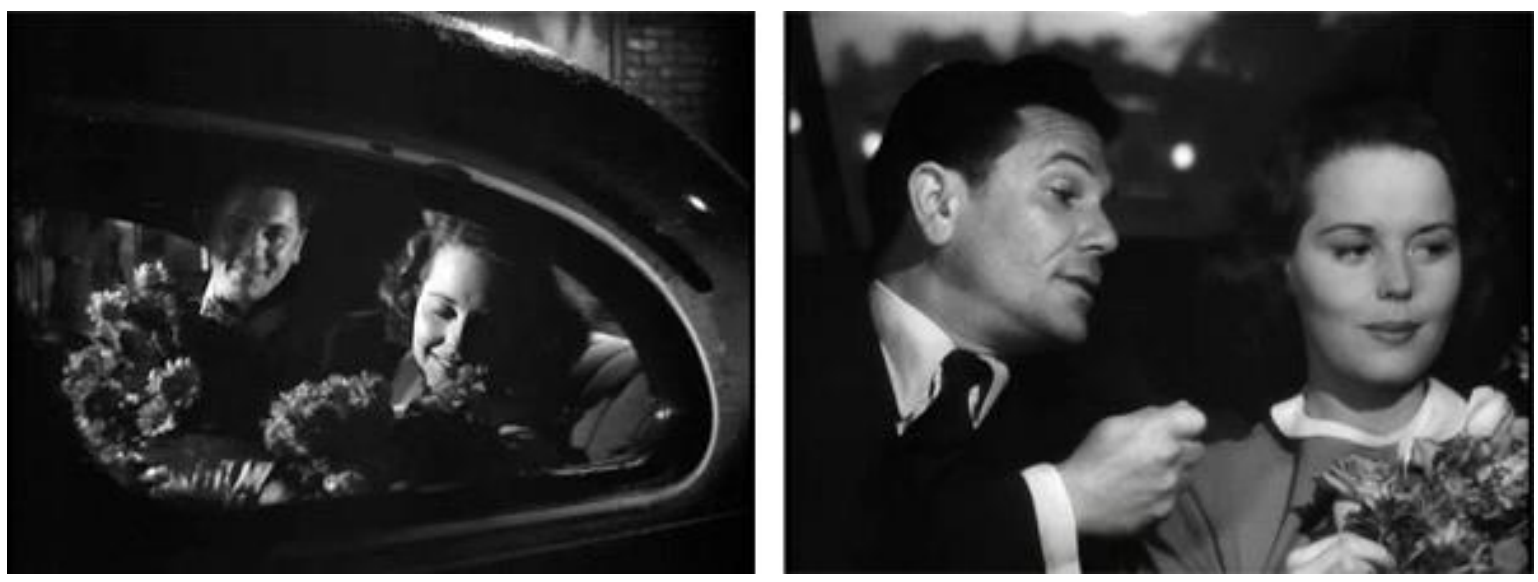

Figura 25 - Doris ganha de Joe as flores e o "rubi”.

A relação entre o galanteio amoroso e as mercadorias é analisada da seguinte forma pelo filósofo Wolfgang Fritz Haug em sua "Critica da Estética da Mercadoria":

Quando Marx afirma que "a mercadoria ama o dinheiro", ao qual ela "acena" com o seu preço lançando "olhares amorosos", a metáfora dirige-se assim para uma base sócio-histórica. Pois um gênero de estímulo forte com o qual a produção de mercadorias opera, objetivando a valorização, é o estímulo amoroso. Por conseguinte, um gênero inteiro de mercadorias lança olhares amorosos aos 
compradores imitando e oferecendo nada mais que os mesmos olhares amorosos, com os quais os compradores tentam cortejar os seus objetos humanos do desejo. Quem busca o amor faz-se bonito e amável. Todas as joias e tecidos, perfumes e maquiagens oferecem-se como meio para representar a beleza e a amabilidade. Do mesmo modo, as mercadorias retiram a sua linguagem estética do galanteio amoroso entre os seres humanos. A relação então se inverte, e as pessoas retiram a sua expressão estética das mercadorias. Ou seja, ocorre aqui uma primeira reação conjunta da forma de uso das mercadorias motivada pela valorização sobre a sensualidade humana. A possibilidade de expressão de sua estrutura impulsiva não só se modifica, como também a sua ênfase se desloca: um forte estímulo estético, o valor de troca e a libido amoldam-se (...); e os meios de expressão tornam-se valiosos, custando também uma fortuna. ${ }^{179}$

Ao oferecer flores e um rubi a Doris, Joe configura em ações o processo descrito por Haug e retira das mercadorias a expressão estética do seu galanteio - não se trata de amor, como o próprio Joe diz em uma cena na casa de Doris, mais adiante no filme. "Não tão cedo, não vou dizer isso", afirma ele, segundos antes de beijar Doris pela primeira vez. Fato é que a relação entre os dois se inicia mediada pela mercadoria, ou seja, fetichizada - Joe também oferece a Doris "dinheiro e pecado" no pacote, e a secretária não aceita e nem rejeita a proposta. Quando o advogado revela que o rubi, por ora, não existe, Doris conta a Joe que se deixava enganar por mágicos porque só prestava atenção ao que falavam, não ao que faziam, ou seja, deixava-se levar pelas aparências.

Assim como na forma mercadoria para Marx, há também em Doris um certo "caráter enigmático" que a personagem tenta sustentar - embora em sua essência já seja "adulta com ficha na polícia", Doris cultiva a aparência de uma "garotinha" inocente. Polonsky também desfaz as aparências de Doris na sequência em que ela e Joe contracenam pela segunda vez. Tal sequência ocorre no saguão do prédio em que Leo e Sylvia moram. Joe está saindo do elevador e encontra Doris tentando entrar nele. Ela segura um chapéu nas mãos enfeitado com as flores que Joe lhe deu na noite anterior. Vemos, então, o seguinte diálogo, acompanhado da mesma melodia extradiegética da cena no carro:

Joe: Se não é a Srta. Lowry! Como vai, Doris? [pega o chapéu da mão de Doris e cheira as rosas que o enfeitam] Está linda com as minhas rosas. Para onde vai?

Doris: Para a casa do seu irmão, vou jantar com ele e sua esposa.

Joe: Eu não iria.

${ }^{179}$ Haug, W. F. Crítica da Estética da Mercadoria. São Paulo: Editora UNESP, 1996, p. 30. 
Doris: Eu sempre vou.

Joe: Não tem nada melhor para fazer? Estou livre pelo resto da noite.

Doris: Bem, aproveite sua liberdade. [Doris tenta pegar o chapéu da mão de Joe, mas ele o afasta da mão dela]

Joe: Eu não os interromperia. Está um clima estranho. [nesse momento, um rapaz passa entre a câmera e os personagens, e entra no elevador atrás de Joe] Deixei um milhão no colo deles e eles estão aprendendo a contar.

Doris: Estão me esperando. [tenta entrar no elevador e Joe a interrompe]

Joe: Eu estou de bom humor, feliz, relaxado. Não quer saber como sou charmoso? [o rapaz que entrou no elevador atrás de Joe gesticula silenciosamente para Doris perguntando se ela quer subir. Doris balança a cabeça negativamente. Joe, de costas para o elevador, entende que o gesto de Doris é para a pergunta que acabara de fazer] Por que não? [o elevador fecha]

Doris: Perdi o elevador.

Joe: Arranjo um melhor para você. [há um corte para um plano médio de Joe e Doris; ele joga o cigarro na lixeira, e ela tenta novamente pegar o chapéu das mãos de Joe, que se movimenta impedindo sua ação; tem início uma sequência de ações dos personagens repetindo esse mesmo movimento, enquanto discutem e circulam pelo saguão, emulando uma valsa] Não quer comemorar com estilo, Srta. Lowry?

Doris: O que está comemorando, Sr. Morse?

Joe: Uma consciência tranquila.

Doris: De quem?

Joe: Não seja tão moralista.

Doris: Meus instintos te reprovam.

Joe: Eu mesmo me reprovo, então concordamos.
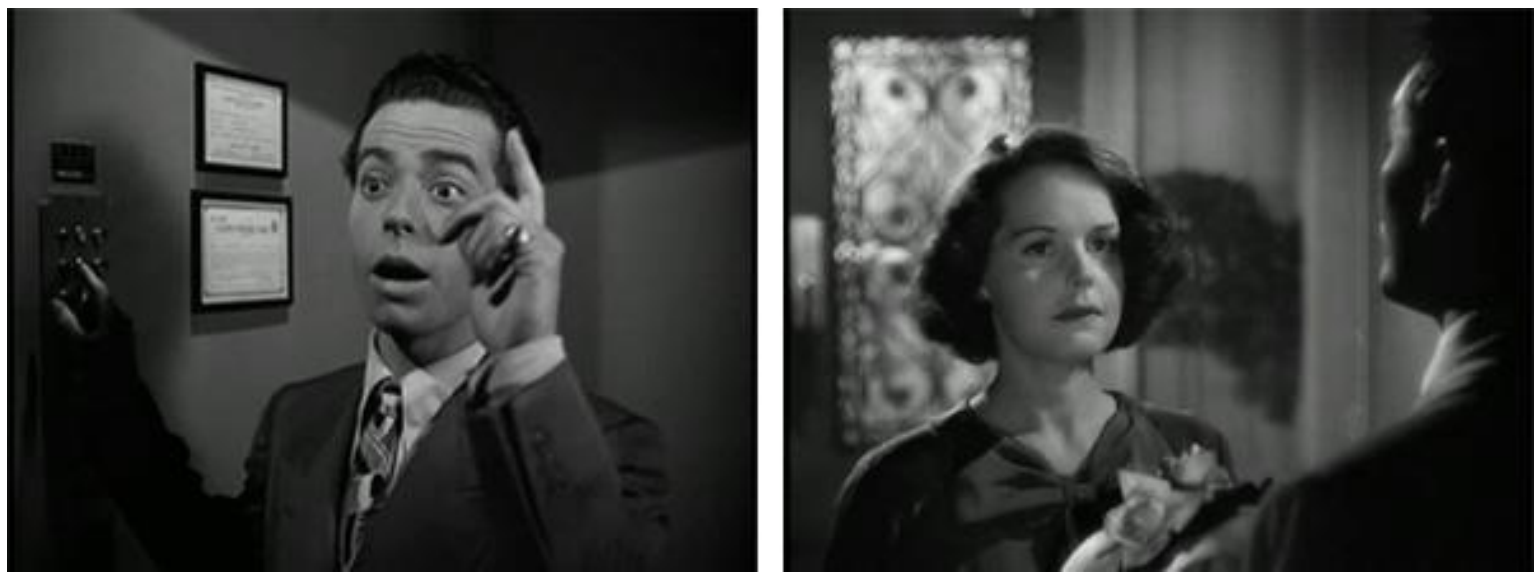

Figura 26 - O rapaz no elevador pergunta a Doris se quer subir; ela recusa a oferta. 
O gesto de Doris negando a oferta do elevador é muito sutil, e o corte é rápido, mas o posicionamento da câmera atrás de Joe e o registro em campo e contracampo ajudam o espectador a entender perfeitamente o que se passa na tela. (Figura 26) Esse é único momento nessa primeira metade do filme em que Doris deixa claro suas intenções a respeito de Joe se não quisesse sua companhia naquele instante, teria sinalizado ao rapaz do elevador que subiria com ele -, mas o diretor registra a cena de forma que somente o espectador tenha acesso a essa informação. Doris prefere manter sua aparência de menina inocente a todo custo.

A pequena valsa incidental que os personagens dançam no saguão do prédio, acompanhada pela música extradiegética, reforça a ambientação romântica da cena, novamente contraposta ao conteúdo do diálogo, que chega a ser irônico em certo momento (“'O que está comemorando, Sr. Morse?”. "Uma consciência tranquila”, “De quem?”). Na continuação da cena, Joe, puxa Doris pelo braço até o meio do saguão e lhe faz uma proposta:

Joe: Venha comigo, vamos jantar, beber vinho e dançar. E nas primeiras horas da manhã, quando você estiver relaxada e cansada, eu... te dou um beijo de boa noite. Doris: Não vai gostar da minha companhia. [tenta pegar o chapéu novamente, sem sucesso]

Joe: Claro, mas você vai gostar da minha. [Joe puxa Doris para perto da lareira do saguão; a câmera acompanha o movimento e se aproxima dos dois] Não diga sim querendo dizer não, e não diga não querendo dizer sim. [Doris sorri, encabulada] Você é como Leo, ele queria entrar no negócio desde o começo, mas queria ser forçado, igual a você, só para manter uma superioridade moral que não existe.

Doris: [corte para um close na personagem com o semblante sério; início do diálogo filmado em campo e contracampo] Você o fez entrar no negócio com Tucker? Você o forçou?

Joe: Fingi que o forçava e ele fingiu que estava sendo forçado. É o que você quer? Doris: Deve haver algo cruel e corrupto em você.

Joe: [interrompendo Doris] Se vai começar o sermão, precisa subir em uma caixa. [ergue Doris pela cintura e coloca-a sentada sobre a lareira do saguão; Doris, visivelmente contrariada, finalmente pega o chapéu de volta]. Você não está muito receptiva hoje. Isso porque não sabe o que quer. [Joe começa a se afastar de Doris, indo em direção à porta do prédio] Quando aparecer no escritório amanhã, por causa do emprego, tento de novo.

Doris: [fora do plano, que filma Joe abrindo a porta] Jamais me verá lá.

Joe: Ainda tenho aquele rubi, Doris. Você ganhava \$35 por semana trabalhando para o Leo, eu pagarei \$100. Aposto um buquê de rosas que você estará lá. [nesse 
momento, o rapaz do elevador do início da sequência sai acompanhado de uma moça; os dois caminham lentamente, olhando com estranheza para Doris, sem entender como nem o porquê dela estar ali; quando se aproximam de Joe, ele dá de ombros, como se nada tivesse a ver com aquilo, e sai do prédio logo depois do casal; a sequência termina com um plano geral do saguão, enquanto Doris chama por Joe discretamente e verifica a altura de onde está até o chão.]

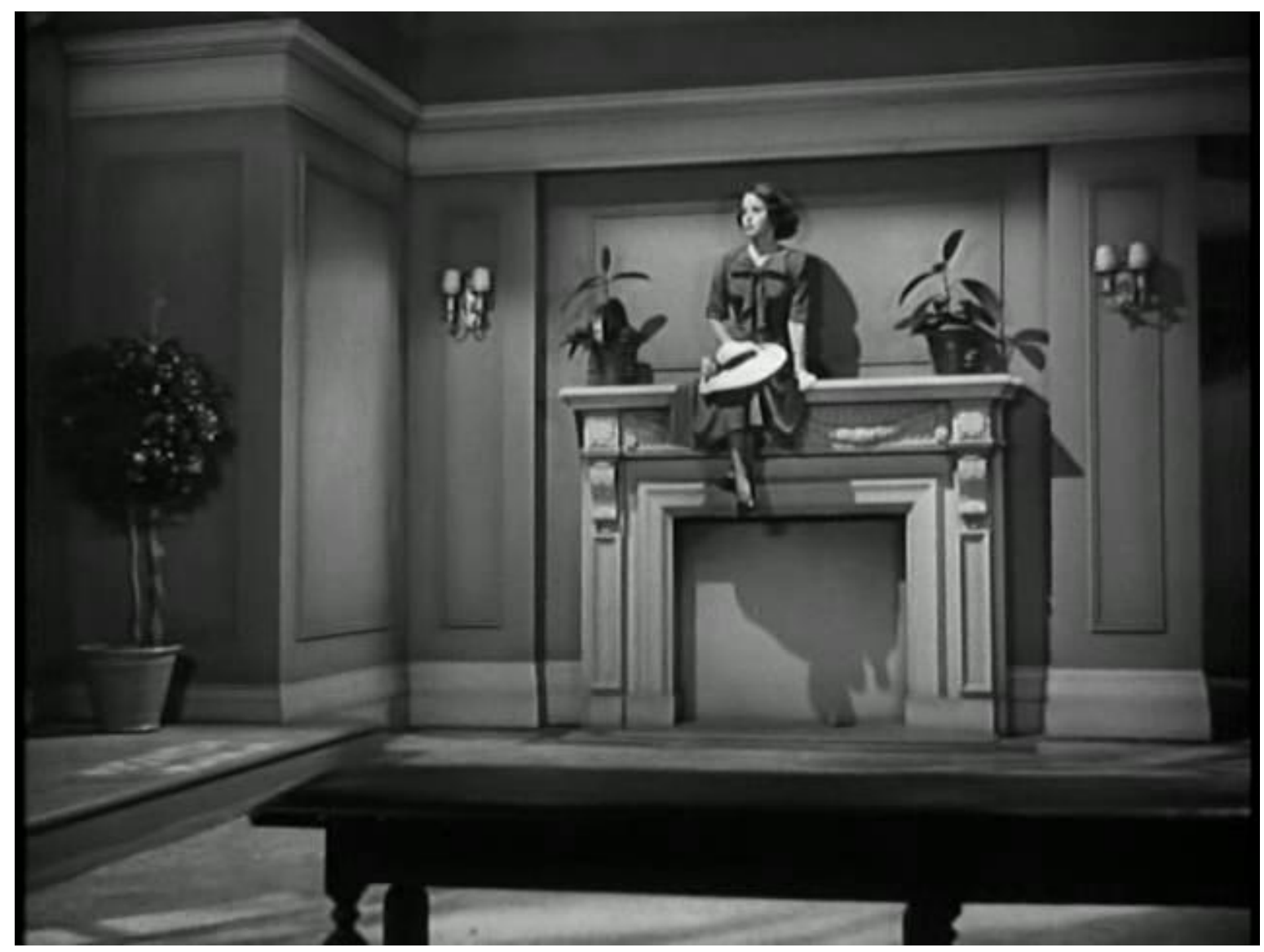

Figura 27 - Doris no saguão do prédio de Leo.

Polonsky retoma a discussão sobre as aparências nesse trecho do diálogo no momento em que Joe faz a proposta à secretária e fecha o cerco em torno de Doris, que "diz não querendo dizer sim". Joe, então, compara a hipocrisia da secretária à de Leo, enuncia o fingimento em que todos na trama estão envolvidos e, quando Doris resolve evocar seu falso moralismo, o advogado coloca-a em seu devido lugar - exposta em um balcão, tal qual mais um objeto de decoração entre as plantas do saguão. A ação de Joe consolida a reificação da personagem, que se torna em cena uma mercadoria qualquer, efetivamente capaz de “"acenar' com o seu preço lançando 'olhares amorosos"”. O fato de Doris entrar em 
contradição e comparecer no dia seguinte ao escritório de Joe para reivindicar seu "rubi", embora, novamente, tenha "dito não querendo dizer sim", materializa o desmonte das aparências da secretária, que não vê outra alternativa a não ser pôr sua força de trabalho à venda a quem ela "instintivamente reprovava" no dia anterior.

A atitude deselegante de Joe não chega a romper com o modo como as mulheres eram tratadas em filmes de gângster na década de 1930 - vide a famosa cena de The Public Enemy em que James Cagney esmaga uma toranja no rosto de Mae Clarke durante o café da manhã -, mas sua ação configura uma quebra com a tradição da cena romântica em Hollywood. A própria escolha de Beatrice Pearson como o par romântico de John Garfield destoa do padrão da figura feminina no cinema noir. Basta compará-la, por exemplo, com Barbara Stanwyck em Double Indemnity (Billy Wilder, 1944) ou Rita Hayworth em Gilda (Charles Vidor, 1946). A esposa de Tucker, Edna (Marie Windsor), está muito mais próxima desse modelo de femme fatale do noir, e sua estratégia é muito mais objetiva e agressiva do que a de Doris; Joe, no entanto, rejeita suas investidas por motivos práticos - afinal de contas, trata-se da esposa de um gângster -, não por lealdade ou amor à secretária.

O término desses primeiros encontros entre Joe e Doris, conforme descrevemos, não são nem um pouco românticos: enquanto no primeiro Joe termina a cena fazendo uma apologia do American Dream, no segundo ele abandona seu par romântico sobre o balcão de uma lareira. Na sua superfície, contudo, tais cenas seriam vistas como passagens românticas do filme, pois são ambientadas com essa finalidade. Como vimos, é na contraposição entre a forma e o conteúdo das cenas entre Joe e Doris que Polonsky aposta suas fichas para provocar um tipo de reflexão incomum em filmes de hollywoodianos.

\section{A censura no pós-guerra e o uso do som}

Em um ensaio sobre o filme The Best Years of Our Lives (William Wyler, 1946), Polonsky afirma que

o artista que trouxer mesmo que uma pequena fração da experiência diária para o estúdio estará contribuindo imensamente para a tela. The Best Years indica para todo diretor e escritor que a luta pelo conteúdo, pela realidade social, não importa 
quão limitado seja o ponto de vista, é uma atmosfera necessária para o desenvolvimento do filme Americano. ${ }^{180}$

As declarações de Polonsky demonstram uma consciência política do papel do artista/trabalhador dentro da indústria cultural. Ao observar as dificuldades no desempenho dessa função, o cineasta chegou à conclusão de que

\footnotetext{
"escrever para o cinema é escrever sob censura", uma censura que "força estereótipos de motivo e de ambiente nos criadores”. A resposta, se possível, era “forçar experiência concreta o suficiente no modelo para fazer a imaginação florescer". ${ }^{181}$
}

Nesse contexto, a "censura" citada por Polonsky tinha duas origens distintas. A primeira era relacionada à "censura autoimposta" citada anteriormente, que resultava, por exemplo, na "inabilidade de Hollywood em lidar com questões de classe, especialmente a classe trabalhadora"182. A segunda tinha a ver com as exigências do Código de Produção de Hollywood (PCA), que limitava cenas de sexo, de violência ou de crimes sem punição. Sobre o primeiro tipo de censura, Force of Evil representa um rompimento com esse padrão ao mostrar, por exemplo, a consciência que os funcionários de Leo demonstram em cena sobre a posição que ocupam na sociedade, conforme veremos mais adiante. Sobre o segundo tipo, uma análise da história do PCA a partir de meados da década de 1930 até o fim da década de 1940 pode nos ajudar a compreender como a censura interferiu no trabalho de Polonsky.

As ações do PCA depois que Joseph Breen assumiu seu comando em 1934 tornaramse mais rígidas do que a abordagem liberal e apaziguadora de Jason Joy, seu antecessor no gerenciamento do Código de Produção. Ainda assim, no geral, os estúdios atenderam às exigências de Breen e dos censores por motivos mercadológicos - sem o selo de aprovação do PCA, os filmes não poderiam ser exibidos e arrecadar bilheteria dentro ou fora do país. A aproximação da Segunda Guerra Mundial no fim da década de 1930, no entanto, mudou o cenário do mercado cinematográfico, especialmente externo. Segundo o historiador Richard Maltby, as reações de Hollywood ao crescimento do fascismo na Europa ao longo da década de 1930 foram de apaziguamento em nome da manutenção dos mercados consumidores. Entretanto, se os EUA baniram alguns dos filmes soviéticos que tentaram

\footnotetext{
${ }^{180}$ Polonsky, A. apud. Buhle, P., Wagner, D. A very dangerous citizen: Abraham Polonsky and the Hollywood Left. Berkeley and Los Angeles: University of California Press, 2001, p. 105

181 Idem.

182 Ibidem, p. 106.
} 
chegar ao mercado norte-americano, a Alemanha nazista e a Itália fascista, por sua vez, passaram a ter maior rigidez no controle das produções cinematográficas que eram importadas, enquanto Japão e URSS tornaram-se mercados completamente fechados. ${ }^{183}$

Durante a Segunda Guerra, o PCA dividiu o controle sobre o conteúdo dos filmes com o Departamento de Cinema do Escritório de Informações de Guerra (Office of War Information - OWI), uma agência governamental criada por Roosevelt para controlar o fluxo de notícias sobre a guerra vindas das forças militares norte-americanas para o público. A função do Departamento de Cinema era supervisionar os scripts paralelamente ao PCA, e incentivar a propaganda de guerra nas produções de Hollywood. Os estúdios não se opuseram à intervenção da OWI, desde que ela não interferisse nos lucros. O avanço das Forças Aliadas a partir de 1943 aumentou a influência do OWI, pois as vitórias militares abriram novamente os mercados europeus aos filmes hollywoodianos, e os estúdios precisavam do selo de aprovação do Departamento de Cinema para que pudessem exportar suas mercadorias. De acordo com Maltby, a indústria cinematográfica norte-americana foi uma entre muitas que se beneficiaram da combinação entre patriotismo e lucro. ${ }^{184}$

Com o fim da Segunda Guerra Mundial, o cenário internacional mudou radicalmente. Alemanha, Japão e Itália encontravam-se sob a censura militar das forças de ocupação, o que permitiu a Hollywood dominar o mercado cinematográfico nesses países com o propósito de funcionar como uma "força no mundo pós-guerra que visa contribuir de maneira vital no desenvolvimento da paz permanente, prosperidade, progresso e segurança em nível mundial" ${ }^{185}$, segundo um executivo da Fox. A expansão do mercado internacional fez do PCA um empecilho aos produtores, que passaram a criticar as restrições temáticas impostas aos scripts. Contudo, o que determinou de fato o início da queda do PCA foi uma decisão judicial da Suprema Corte em 1948 no caso antitruste movido pelo governo norte-americano contra a Paramount. Além de incluir o cinema entre as mídias que gozam da liberdade de expressão garantida pela Primeira Emenda da Constituição, a Suprema Corte também acabou com o oligopólio que os estúdios tinham sobre cadeias de salas de cinema. ${ }^{186}$

Tal decisão judicial impôs derrotas ao PCA em duas frentes: na primeira, restringiu o trabalho da censura sobre o conteúdo dos filmes - nos três anos seguintes a essa decisão,

\footnotetext{
${ }^{183}$ Maltby, R. Censorship and Self-Regulation. In: Nowell-Smith, G. (ed.). The Oxford History of World Cinema. New York: Oxford University Press, 1996, p. 245.

184 Idem.

185 Ibidem, p. 247.

186 Ibidem, p. 247-248.
} 
a Suprema Corte julgou inconstitucionais as censuras estaduais e municipais sobre as produções cinematográficas, exceto em caso de "obscenidades"; na segunda, limitou o controle que o PCA exercia sobre o mercado cinematográfico, pois a autoridade do órgão dependia da integração vertical entre produção, distribuição e exibição dos filmes, e o selo de aprovação do PCA era fundamental para os lucros dos estúdios no mercado doméstico. Com o fim do oligopólio, as salas de cinema estavam livres para exibir o que bem entendessem. Foi assim, por exemplo, que Ladrões de Bicicleta (Vittorio De Sica), ganhador do Oscar de Melhor Filme Estrangeiro em 1949, pôde ser exibido nos EUA com distribuição independente e sem o selo de aprovação do PCA. Mais adiante, em 1953, a United Artists se recusou a fazer as modificações solicitadas por Breen em The Moon is Blue (Otto Preminger), que se tornou o primeiro filme de um grande estúdio a ser exibido em solo norteamericano sem o selo do PCA, ${ }^{187}$ que ainda atuou em Hollywood até o fím da década de sessenta, quando a Motion Pictures Association of America (MPAA) substituiu-o pelo sistema de classificação por faixas etárias que vigora até hoje. ${ }^{188}$

A história do Production Code Administration nos mostra que, em 1948 - ano de lançamento de Force of Evil -, o órgão de censura enfrentava sua pior derrota judicial, curiosamente relacionada à mesma discussão sobre monopólio/oligopólio levantada pelo enredo do filme. Segundo Buhle e Wagner,

\begin{abstract}
a atmosfera de luta política está em todos os aspectos de Force of Evil, do script à produção, e até mesmo no contexto histórico. Como aponta [Robert] Sklar, o enredo alveja diretamente o pescoço do monopólio, não apenas das loterias ilegais de Nova Iorque, mas, por implicação, também dos grandes estúdios. No ano anterior, a Suprema Corte havia declarado os estúdios culpados por violarem o Sherman Antitrust Act [lei antitruste] e obrigou-os a abrir mão de cadeias de salas de cinema - o que viabilizou economicamente o filme de arte na agenda dos administradores de cinema independentes. ${ }^{189}$
\end{abstract}

De acordo com os arquivos do PCA, a primeira versão do roteiro de Force of Evil (cujo título ainda era Tucker's People) foi sumariamente rejeitada pelos censores por violar o primeiro Princípio Geral do Código de Produção: "Nenhum filme que rebaixe os valores

\footnotetext{
${ }^{187}$ Cf. Maltby, R. Censorship and Self-Regulation. In: Nowell-Smith, G. (ed.). The Oxford History of World Cinema. New York: Oxford University Press, 1996, p. 248.

${ }^{188}$ Cf. Bernstein, M. Controlling Hollywood: Censorship and Regulation in the Studio Era. London: A\&C Black, 2000, p. 238.

${ }^{189}$ Buhle, P., Wagner, D. A very dangerous citizen: Abraham Polonsky and the Hollywood Left. Berkeley and Los Angeles: University of California Press, 2001, p. 118.
} 
morais daqueles que o virem será produzido. Consequentemente, a simpatia dos espectadores nunca deve ser levada para o lado do crime, transgressão, mal ou pecado". Segundo o parecer do PCA, a simpatia do espectador era direcionada não só aos banqueiros e seus empregados - todos transgressores da lei -, mas também à própria transgressão em si. Além disso, havia a sugestão de que a legislação do Estado de Nova Iorque poderia ser manipulada a favor dessa organização criminosa, e de que a Polícia de Nova Iorque era composta por uma "gangue de bandidos". Em suma, "o tema completamente antissocial desse enredo, que apresenta errado como certo, e certo como errado, viola tanto a letra como o espírito do Código de Produção". Quem assina esse parecer é Stephen S. Jackson, que, além de censor, também era juiz e católico praticante. ${ }^{190}$

Quem responde ao Sr. Jackson é o próprio Polonsky, que afirma estar disposto a eliminar todas as referências que depreciem a imagem da Polícia de Nova Iorque a fim de que o script se adeque às demandas do PCA. Polonsky também aproveita a oportunidade para deixar claro que Force of Evil é uma "exposição dos efeitos nocivos de uma loteria ilegal nas vidas e personalidades de pessoas envolvidas, seja em grande ou larga escala" e resume o enredo de forma a corroborar essa afirmação. Sobre a primeira batida policial, por exemplo, Polonsky descreve a reação de Doris da seguinte maneira:

\begin{abstract}
Agora que a lei bateu à porta da banca de Leo, por causa de uma denúncia anônima plantada por Joe, Doris vira-se contra Leo. O choque da batida policial, o aparecimento da lei, destrói Doris no momento em que ela percebe o quanto se enganou ao acreditar em Leo. Todo o senso de lealdade a Leo, toda memória de sua bondade no passado é destruída pela realidade. Ela o acusa de seu autoengano, culpa-se por sua própria cegueira e avisa-o de que o fim disso tudo será sua própria destruição, e daqueles que trabalham para ele. Leo, enquanto ouve essa garota que se tornou uma filha para ele, sente seu autoengano dissipar aos poucos, e sente crescer o sentimento de que precisa expurgar-se e sair desse negócio nocivo em que se encontra. ${ }^{191}$
\end{abstract}

Embora na versão final do filme seja Joe quem abra os olhos de Doris sobre a ilegalidade das operações de Leo, Polonsky carregou nas tintas que descrevem a decepção de Doris com Leo porque sabia o quão importante era o aspecto moral do enredo na visão

\footnotetext{
${ }^{190}$ Carta de Stephen S. Jackson a David J. Hopkins. 5 de abril de 1948. In: Force of Evil files. Production Code Administration Archive, Margaret Herrick Library, Academy of Motion Picture Arts and Sciences. Los Angeles, California. p. 5-6.

${ }^{191}$ Carta de Abraham L. Polonsky a Stephen S. Jackson. 7 de abril de 1948. Ibidem. p. 9.
} 
dos censores - os anos de experiência como escritor antes de ir para Hollywood deram-lhe a habilidade necessária para contornar a censura. A carta enviada por Polonsky teve o efeito desejado: embora Jackson ainda solicite pequenas alterações e faça ressalvas isoladas nas correspondências seguintes, o enredo descrito por Polonsky tem a aprovação do censor, bem como os subsequentes scripts enviados ao PCA.

O aval do Breen Office a um filme como Force of Evil, mesmo com alterações em alguns aspectos da narrativa, foi uma vitória política de Polonsky e sua equipe. Dessa maneira, ainda que sob os limites impostos pelas relações de produção dentro da indústria cultural, Polonsky via no seu trabalho uma oportunidade de modificar o aparelho burguês "por dentro se as técnicas da moda forem usadas contra o capital e, portanto, de uma perspectiva política" ${ }^{192}$. Segundo o próprio Polonsky, as condições de produção que ele e seus companheiros de trabalho encontraram eram ímpares:

[N]ós tínhamos à disposição a grande máquina de Hollywood que o sucesso de Body and Soul nos proporcionou, e não nos importávamos tanto com o que era possível fazer com tanto poder. Mas a lista negra tirou a máquina de nossas mãos. Enquanto tínhamos posse (...) nós não víamos a hora de acordar de manhã, sabendo que cada dia nos surpreenderia. Nós tínhamos a sensação certa. Só que o nosso avião nunca decolou. ${ }^{193}$

Diferente do que havia ocorrido em Body and Soul, onde era somente roteirista, em Force of Evil Polonsky acumulou também o cargo de diretor da obra, o que lhe possibilitou um controle ainda maior sobre o modo como imagens e narração ou diálogos se relacionariam dentro do filme. Dessa maneira, Polonsky tinha à disposição tanto o aparato de Hollywood como a autonomia necessária para que pudesse desenvolver seu trabalho com certa liberdade criativa e consciência política. Segundo o próprio cineasta, tais condições de produção permitiram que Force of Evil fosse executado de maneira experimental:

Eu não projetei nada importante, só um experimento em que cada um dos meus recursos [imagem, ator e palavra] estivesse livre do domínio dos outros dois. Eu era inexperiente demais para inventar imagens originais ou evocar grandes performances. E, certamente, não havia nada no meu passado literário que

\footnotetext{
192 Costa, I. C. Palestra sobre o ensaio O Autor como Produtor. In: Soares, M., Cevasco, M. E. (ed.) Crítica cultural materialista. São Paulo: Humanitas, 2008, p. 98.

${ }^{193}$ Pechter, W. S. Conversations with Abraham Polonsky/1962\&1968. In: Polonsky, A. Abraham Polonsky: interviews / edited by Andrew Dickos. Jackson: University of Mississippi Press, 2013, p. 41.
} 
sugerisse uma Nova Voz. Tudo o que eu tentei foi usar a sucessão de imagens, as demonstrações de personalidade humana nos atores, e o ritmo das palavras em uníssono ou em contraponto. Eu variei a velocidade, intensidade, harmonia e conflito pela intenção, emoção ou objetivo, algumas vezes separando os três elementos, outras usando dois ou três juntos. ${ }^{194}$

Um bom exemplo do que Polonsky descreve acima ocorre na sequência em que os capangas de Ficco sequestram Leo e assassinam Bauer. Desde que ela tem início, a melodia extradiegética é melancólica, próxima de uma elegia religiosa. Bauer diz a Leo que a única coisa que quer é sair do negócio com Tucker. "Se eu não sair, eu morro", explica Bauer, ao que Leo responde:

Leo: [falando em tom baixo, pausado e grave] Sou um homem com problemas cardíacos, morro quase todos os dias. É assim que eu vivo. É um hábito tolo. Sabe, às vezes você sente que está morrendo. Aqui... [esfrega a palma da mão] E aqui... [esfrega a parte superior dos dedos] Aqui. [apalpa a região do coração] Você está morrendo enquanto respira.

Em seguida, ouve-se ao fundo um carro estacionando em frente ao café onde Leo e Bauer conversam, e três homens armados saem do veículo. Bauer, que está sentado de frente para a porta do estabelecimento, olha com espanto para essa movimentação e Leo, percebendo que havia caído em uma armadilha, grita: "Freddy! O que você fez comigo?!". Um dos bandidos permanece à porta e rende outros clientes do café, enquanto os outros dois pegam Leo, já quase desmaiado, pelos braços. Bauer, assustado, tenta fugir. Nesse momento, Wally grita para o bandido à porta parar Bauer, que leva uma rasteira e cai ao pé da escada para a rua. "Mate ele! Ele me conhece!", grita Wally, e arranca o revolver das mãos do bandido. Há, em seguida, uma sequência de campo e contracampo, mostrando Bauer em plongée com o rosto sangrando, óculos quebrados e olhar apavorado - , e Wally em contra-plongée, com a arma apontada diretamente para a câmera. Wally, então, atira e mata Bauer à queimaroupa. Em seguida, o volume da música extradiegética aumenta levemente, mas a melodia não se altera, e a sequência termina com os bandidos carregando Leo para fora do café.

194 Pechter, W. S. Conversations with Abraham Polonsky/1962\&1968. In: Polonsky, A. Abraham Polonsky: interviews / edited by Andrew Dickos. Jackson: University of Mississippi Press, 2013, p. 41. 

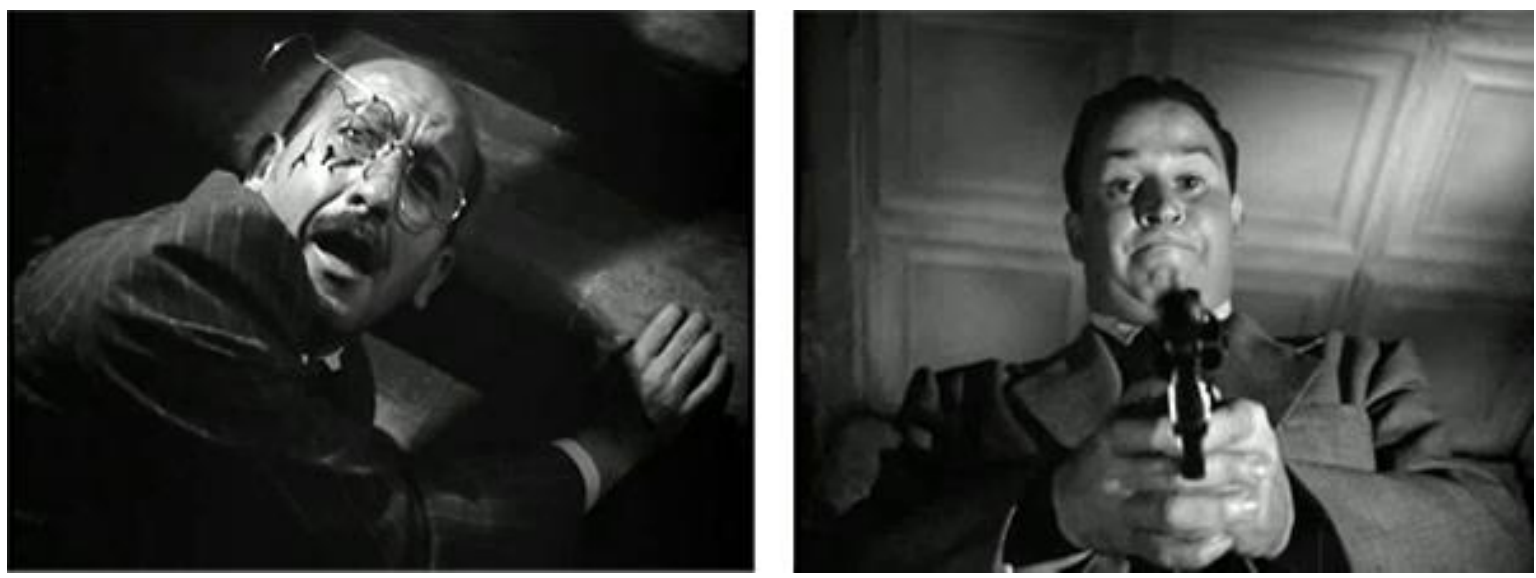

Figura 28 - Bauer ao pé da escada e Wally atirando à queima-roupa

Dois pontos dessa sequência merecem destaque. O primeiro deles é a relação entre a melodia extradiegética e as imagens na tela. Preocupado com os rumos que a exploração comercial dos filmes falados traria ao cinema, o cineasta e teórico russo Sergei Eisenstein propõe, em 1928, no ensaio intitulado "Declaração sobre o futuro do cinema sonoro", que "o primeiro trabalho experimental com o som deve ter como direção a linha de sua distinta não-sincronização com as imagens visuais"195. Segundo Eisenstein, usar o som de outra maneira

destruirá a cultura da montagem, porque cada ADESÃO do som a uma peça de montagem visual aumenta sua inércia como uma peça de montagem, e aumenta a independência de seu significado - e isto sem dúvida ocorrerá em detrimento da montagem, agindo em primeiro lugar não sobre as peças de montagem, mas em sua JUSTAPOSIÇÃO.

APENAS UM USO POLIFÔNICO do som com relação à peça de montagem visual proporcionará uma nova potencialidade no desenvolvimento e aperfeiçoamento da montagem. ${ }^{196}$

Em outros termos, Bertolt Brecht, em seu texto On Film Music, defende que "a separação dos elementos de música e ação podem proporcionar novos efeitos". Nesse caso o planejamento e o trabalho conjunto com o compositor da trilha sonora do filme são essenciais para que se atinja o resultado desejado. Dessa maneira, a música deixaria de ser mero acompanhamento da ação, e ganharia autonomia ao se transformar em um

195 Eisenstein, S. Declaração sobre o futuro do cinema sonoro. In: A forma do filme. Rio de Janeiro: Jorge Zahar Ed., 2002, p. 226.

196 Idem. 
“complemento dramático de fato” (grifo nosso) ${ }^{197}$. O dramaturgo alemão ainda cita um exemplo:

\begin{abstract}
Um jovem leva sua namorada para um passeio no lago, vira o barco e deixa a garota se afogar. O compositor tem duas escolhas. Ele pode antecipar os sentimentos do público com sua música de acompanhamento, desenvolvendo a tensão, amplificando a vilania do ato, etc. Ou então ele pode expressar na música a serenidade do lago, a indiferença da natureza, a qualidade e a simplicidade da simples excursão. Se ele escolhe essa última possibilidade, permitindo ao homicídio parecer ainda mais horrendo e estranho, ele dá à música uma função muito mais independente. ${ }^{198}$
\end{abstract}

Podemos dizer que o tratamento que Polonsky deu às imagens e à música na sequência do sequestro de Leo é análogo àquele proposto por Sergei Eisenstein e Bertolt Brecht. Em linhas gerais, Force of Evil tem pouquíssimas cenas de tiroteio para um filme de gângster - bem menos do que encontramos em outros filmes do gênero - e, quando tais cenas ocorrem, o registro da violência é diferente do que ocorria nos primeiros filmes de gângster da década de 1930, principalmente no que diz respeito à utilização do som no filme. Enquanto o procedimento usual era manter uma harmonia entre imagem e música extradiegética, a proposta do cineasta nessa sequência é, justamente, a quebra desse padrão por meio da separação entre esses dois elementos. Dessa forma, embora a elegia religiosa combinasse perfeitamente com o discurso que Leo faz sobre a morte, a ação rapidamente muda para um sequestro seguido de um assassinato, mas a música não se altera, somente o volume dela aumenta ligeiramente ao fim da cena. Em vez de mudar a trilha sonora para acompanhar a tensão da ação, Polonsky optou por manter a mesma música em toda a sequência. Segundo o cineasta, o objetivo desse procedimento foi gerar uma "inquietude" no espectador, que, em última análise, pode se questionar sobre a banalidade de sequestros e assassinatos na sociedade em que ele vive: "Quando você faz algo desse tipo, você utiliza o familiar de maneira a chamar a atenção para o fato de que não é tão familiar assim no fim das contas"

\footnotetext{
${ }^{197}$ Brecht, B. On Film Music. In: Silberman, M. (ed.) Brecht on Film \& Radio. London, Methuen, 2000, p. 14.

${ }^{198}$ Idem.

199 Sherman, E, Rubin, M. Interview with Abraham Polonsky. In: Polonsky, A. Abraham Polonsky: interviews / edited by Andrew Dickos. Jackson: University of Mississippi Press, 2013, p. 57.
} 


\section{Lealdade em tempos sombrios}

Entre as refuncionalizações que Polonsky opera na forma do filme de gângster tradicional, a figura do delator ocupa um lugar de destaque. Em Little Caesar o delator é Tony Passalacqua (William Collier Jr.), que se acovarda depois de participar de um latrocínio com a gangue e, momentos antes de se confessar a um padre, é assassinado por Rico; em Force of Evil, quem assume esse papel é Freddie Bauer (Howland Chamberlain), o contador da banca de apostas de Leo; entretanto, em vez de ser um simples delator, Bauer funciona no filme de Polonsky como um informante tanto para a polícia, como para Bill Ficco (Paul Fix), o gângster que quer entrar no mercado de loterias ilegais com Tucker.

Bauer é caracterizado como um homem franzino, calvo, cujos movimentos são comedidos; sua voz tem sempre tom grave e volume baixo; seu porte físico se reflete na sua personalidade, pois as cenas com o personagem o mostram com o semblante tenso, cada vez mais arredio e preocupado à medida em que seu envolvimento com o crime organizado aumenta ao longo do filme. A primeira cena em que o contador demonstra tal preocupação é importante para a narrativa porque também é por meio dela que o espectador entende de que maneira o cotidiano dos funcionários mudará com a fusão das bancas de apostas.

A sequência tem início no momento em que Bauer chega ao trabalho no dia seguinte ao "sorteio" do número 776. O contador bate à porta do apartamento e quem atende é Johnson (Tim Ryan), um dos capangas de Tucker. "Bela hora para chegar. De agora em diante, chegue na hora certa", avisa Johnson, em tom de ameaça. O enquadramento dessa cena é similar àquele da sequência em que Joe chega à banca de Leo pela primeira vez, mas o ambiente mostrado em cena é completamente diferente. $\mathrm{O}$ tilintar alto das moedas nas máquinas manuais é substituído por um vozerio abafado vindo da sala de Leo, e os funcionários da banca dão lugar a homens engravatados, aparentemente empregados de Tucker, que observam Bauer entrar no apartamento. (Figura 29) Ao notar a mudança no seu ambiente de trabalho e ouvir o aviso de Johnson, o contador sente-se intimidado, agarra seu chapéu junto ao corpo com as duas mãos e segue para a sala de Leo ao fundo.

No momento em que Bauer se aproxima da porta e a abre lentamente, é possível ouvir a voz de Leo explicando os termos do acordo com Tucker: 
capital que pegamos emprestado para pagar o 776 é uma penhora dentro do negócio, com juros de 6\%, além de um bônus de $\$ 5.000$ pelo empréstimo. Será pago semanalmente de acordo com a capacidade de cada negócio. Cada banqueiro terá uma conta de $\$ 75$ por semana, até a dívida estar paga. E 1/3 do lucro. Está claro?

Joe: [levantando-se em direção à porta, dá um tapa nas costas de Bauer e diz, entusiasmado] Você agora é contador de uma grande organização, Sr. Bauer! [sai da sala]

Leo: Sr. Richards, vou ser direto, não tenho boas notícias para você.

Richards: [sentando-se à frente de Leo] Estou me acostumando com isso.

O enquadramento da cena mostra Bauer entrando na sala de Leo em um plano fechado; à medida que ele olha a seu redor e dá alguns passos dentro da sala, a câmera se distancia de Bauer por uma grua, ampliando o enquadramento para um plano geral em plongée, que mostra Leo sentado à sua mesa, de costas para a câmera, lendo os termos do financiamento em um papel, enquanto os outros banqueiros permanecem sentados ao seu redor, com Joe à direita do enquadramento. (Figura 29)
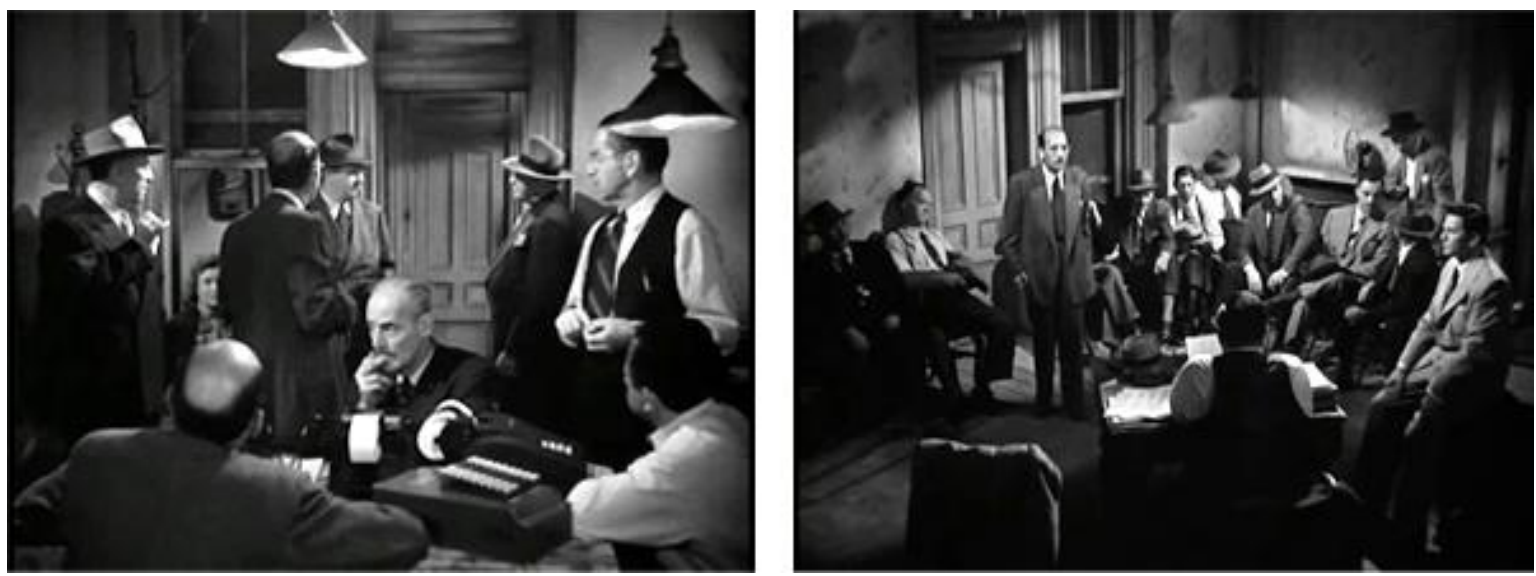

Figura 29 - Bauer chega ao trabalho dominado pelos homens de Tucker (esq.) e observa Leo ler os termos do empréstimo (dir.)

A sequência mostra a reação de Bauer em seu primeiro contato com as consequências da ação monopolista do capital. Assim que o plano de Tucker entra em ação e provoca a quebra das bancas de apostas de forma deliberada, as relações de produção dentro da banca de Leo se transformam automaticamente. A ausência dos seus colegas de trabalho somada à cobrança de Johnson e à frieza dos outros funcionários de Tucker fazem o contador se sentir 
acuado naquele ambiente, agora estranho e opressor. Na cena seguinte, Bauer tem outro choque ao se deparar com os outros donos de bancas de apostas ouvindo de Leo as condições impostas por Tucker para o funcionamento dos negócios daquele momento em diante. $\mathrm{O}$ movimento de câmera, que sai de um plano fechado em Bauer para outro mais aberto, filmado de cima para baixo, amplia a sensação de isolamento e desconforto do contador diante da nova realidade do seu ambiente de trabalho. Além disso, a configuração do espaço cenográfico lembra uma reunião em um ambiente corporativo, e o discurso de Leo é o mesmo que se ouve de um gerente de banco ao se pedir um empréstimo. A diferença está na franqueza de Leo ao revelar a Richards que não lhe traz boas notícias - uma realidade costumaz nas negociações de empréstimos em qualquer agência bancária, mas que é disfarçada pelo discurso treinado do gerente. A resignação na resposta de Richards nos mostra que a frequência de más notícias minou qualquer poder de reação perante a força do capital monopolista, e que, naquele momento, não há alternativas para o pequeno empresário.

Na sequência, Bauer pede a Leo uma conversa em particular. Os dois seguem para uma sala, fecham as portas, e o contador pede sua demissão, pois aquele lugar deixa-o "enojado".

Bauer: Sr. Morse, por que me meteu nisso?

Leo: [levantando a voz] Não te meti em nada, eles é que me meteram nisso!

Bauer: Você me meteu nisso sem eu saber? Você fez isso comigo?

Leo: Você veio trabalhar em uma loteria ilegal porque queria um dinheiro extra. Agora você terá um aumento, você está trabalhando para uma grande corporação em vez de um pequeno banqueiro. Você é contador de treze bancas em vez de uma. [em tom irônico] Você está subindo na vida!

Bauer: Eu não quero! Não sou seu escravo! [sai correndo da sala]

A ironia no discurso de Leo pode ser entendida dentro do âmbito dos filmes de gângster. Nesse universo, "subir na vida" era expressão corriqueira, que expressava a ambição do gângster dentro do American Dream; dessa forma, por estar, mesmo a contragosto, envolvido com o crime organizado, Bauer poderia seguir o mesmo caminho. Leo também é irônico nesse momento porque ele está na mesma situação que Bauer, ou seja, não se aliou a Tucker porque queria "subir na vida", mas, sim, por força das circunstâncias. Tanto a reação de Leo como a de Bauer reiteram a ideologia de que o mero trabalho com as loterias ilegais era um "delito menor" - a aliança com Tucker determinaria, assim, um degrau 
na escala criminosa que o contador não está disposto a subir por questões morais, ao menos a princípio.

Quando Bauer sai da sala, é interrompido por Joe, que pergunta a Leo o que está acontecendo. Leo explica que Bauer quer se demitir e diz que não pode fazer a fusão das bancas sem seu contador. "Não tenho estômago para esse tipo de negócio", diz Leo. "O que você quer dizer com 'esse tipo de negócio'? Toda organização precisa contar com seu pessoal quando necessário", Joe responde e diz a Leo: "Volte lá e termine de gravar aquelas lápides que eu cuido de Bauer", enquanto leva o contador de volta à sala, seguido por Johnson.

Joe: [falando calmamente] Sr. Bauer, quero esclarecer todos os problemas que estiverem acontecendo aqui.

Bauer: [segurando o chapéu com as duas mãos, mexendo-as nervosamente] Não tem problema nenhum, só quero sair.

Joe: E isso é justo?

Bauer: Talvez não seja, mas é o que eu quero fazer.

Joe: Por que quer causar um problema para você mesmo?

Bauer: [Corte para um plano mais fechado de Bauer e Joe. Bauer hesita.] O que quer dizer?

Joe: Bem, estamos reorganizando todo o negócio agora. Precisamos da lealdade de todo mundo nesse momento.

Bauer: Você não pode me obrigar a ficar. Não pode. O que vai fazer?

Joe: Quero ser amigo de todos vocês. Quero trabalhar com todos de forma amigável. Não acredito em um patrão que precisa dizer aos seus empregados "você precisa fazer isso". Gosto de um patrão cujos empregados fazem as coisas porque gostam, porque são leais ao negócio.

Bauer: [agitado] E se eu sair daqui agora, o que você vai fazer para me deter? Se eu disser que não fico aqui, como vai me deter? [Joe olha para fora do plano, na direção de Johnson, que está sentado ao lado dos dois. Corte para um plano mostrando somente Johnson]

Johnson: A organização vai te deter, Sr. Bauer. Vai te deter morto. No meio do caminho,

Joe: Viu, Sr. Bauer? Só estou tentando ajudar. [pega o chapéu da mão de Bauer e coloca no móvel ao lado] O que me diz? [Bauer permanece cabisbaixo]

Johnson: [levanta-se e leva Bauer em direção à porta] Avise se tiver algum problema que eu resolvo para você. Esse é o meu trabalho. 
Bauer e Joe configuram nessa cena, respectivamente, o trabalhador e o representante legal da corporação, que negocia a permanência de um empregado fundamental para o bom andamento dos negócios. Podemos interpretar o diálogo entre os dois personagens sob duas chaves alegóricas distintas, ambas relacionadas à matéria histórica com a qual Polonsky lidava durante a produção do filme. A primeira diz respeito à estreita relação entre negócios legais e ilegais, que aparece de maneira reiterada ao longo de Force of Evil: o discurso de Joe para convencer Bauer a continuar no emprego é dissimulado e, no limite, contraditório, pois evoca princípios morais como a justiça, a amizade e a lealdade em um contexto caracterizado pela instabilidade nas relações sociais. Curiosamente, quem desfaz a contradição no discurso de Joe é o gângster Johnson, no momento em que o personagem expõe para Bauer os termos do seu novo contrato de trabalho: seja leal ou morra. A fala curta do gângster revela ao espectador que o criminoso é mais honesto e direto que Joe, cujo discurso procura dissimular a truculência do ambiente de trabalho na banca após o monopólio de Tucker.

A segunda chave alegórica está na perseguição política que os artistas de Hollywood passaram a sofrer com a caça aos comunistas e a condenação dos Hollywood Ten pelo HUAC em novembro de 1947, cerca de um ano antes do lançamento de Force of Evil. Ao questionar a fidelidade de Bauer, Polonsky também chama a atenção de seus colegas que, assim como ele próprio, certamente seriam intimados a depor perante o comitê, cuja principal demanda era a delação de outros artistas ligados ao Partido Comunista e a atividades "subversivas". É por meio de Garfield que Polonsky avisa: "Precisamos da lealdade de todo mundo nesse momento".

A cena seguinte, entretanto, mostra um diálogo entre Bauer e outros empregados de Leo, que não demonstram qualquer intenção de mostrar lealdade ao empregador. É fim de expediente, e a câmera registra três funcionários se arrumando para ir embora:

Funcionária 1: Acho que vou largar esse emprego. Não gosto de trabalhar em um lugar dirigido por gângsteres e que têm batidas policiais. [Bauer entra em cena] Funcionário 2: [pega uma moeda de dentro das máquinas de contar e mostra para os colegas] Está vendo essa moeda? Pertence a Tucker. Assim como nós.

Funcionária 1: Bem, vou sair de qualquer jeito. Tenho medo de trabalhar aqui. Bauer: Do que está falando? [corte para um close de Bauer] Não podemos sair, eles não vão deixar. [Bauer caminha em direção aos colegas e a câmera acompanha em pan shot até enquadrar todos eles, com Bauer e o Funcionário 2 em primeiro plano] Vocês ouviram, disseram que me matariam se eu saísse. 
Funcionária 1: Eles disseram que matariam você, Sr. Bauer. Você é o contadorchefe aqui. Eles precisam de você. Eles não precisam da gente.

Funcionário 2: Talvez estejamos todos desempregados em breve. Li no jornal que Hall disse que vai acabar com as bancas. Ele poderia fazer isso se soubesse onde elas estavam e para onde se mudam.

Funcionário 3: Você vem, Sr. Bauer?

Bauer: Não, ainda tenho algumas coisas para fazer.

O que diferencia o trabalho de Polonsky daquele desenvolvido por seus colegas em Hollywood é, de acordo com o historiador Andrew Dickos, a qualidade de sua escrita, uma vez que

[Polonsky] escrevia intrepidamente, seus roteiros [são] livres da censura autoimposta que amiúde enfraquecia os filmes de outros cineastas. Polonsky escreveu alegorias contundentes do sistema capitalista - o mesmo sistema que produziu suas obras -, e fazia-o com fundamentos humanistas: seus personagens não carregam cartazes, não têm orientação política evidente, e não são mártires. São pessoas e rostos encontrados na sociedade urbana moderna que sofrem a pressão de uma cultura capitalista corrupta e ambiciosa. Sessenta anos depois, nunca esse tema teve tanto poder como na América pós-recessão de 2012. ${ }^{200}$

De fato, os personagens de Force of Evil não carregam cartazes, mas, por meio da narração e dos diálogos criados por Polonsky, é possível notar a consciência da posição na sociedade que cada um deles ocupa. Na cena descrita acima, por exemplo, chama-nos a atenção a franqueza com que os empregados reconhecem a própria impotência perante o poder do monopólio estabelecido por Tucker, que alienou os trabalhadores do seu próprio ambiente de trabalho ao ponto de eles terem medo de permanecerem ali, preferindo o desemprego ao perigo que um lugar dominado pelo crime organizado representa. Um dos funcionários vai além e enuncia a consciência de sua própria reificação ao constatar que ele e seus colegas são propriedade de Tucker, tanto quanto o dinheiro que entra nas máquinas da banca. Segundo Friedrich Engels e Karl Marx,

[a] burguesia - isto é, o capital - se desenvolve, desenvolve também o proletariado, a classe dos operários modernos, que só vivem enquanto têm trabalho e só têm trabalho enquanto seu trabalho aumenta o capital. Estes operários, que

\footnotetext{
${ }^{200}$ Dickos, A. Introducion. In: Polonsky, A. Abraham Polonsky: interviews / edited by Andrew Dickos.
} Jackson: University of Mississippi Press, 2013, p. ix. 
tem de vender-se no varejo, são uma mercadoria como qualquer outro artigo de comércio e estão, por isto mesmo, igualmente expostos a todas as vicissitudes da concorrência, a todas as flutuações do mercado. ${ }^{201}$

O funcionário assinala a instabilidade do mercado de trabalho naquele momento ao ressaltar que o procurador Hall pode fazer todos perderem o emprego se encontrar as bancas de apostas. Ao ouvir essa informação, Bauer liga anonimamente para o escritório do procurador e dá o endereço da banca de Leo:

Bauer: [ao telefone] Quero que deem a batida logo, amanhã, quando abrirem. Quando abrirem de novo, vocês dão outra batida. Onde quer que seja, eu aviso. Quero que fechem o negócio. [pausa] Não importa quem sou. Se derem essa batida, digo onde estão os outros também. Se eles se mudarem, eu aviso para onde.

Ao incluir a figura do delator em Force of Evil, Polonsky segue o "sistema de convenções de representação" estabelecido para os filmes de gângster durante a década de 1930, mas a matéria histórica sob a qual o diretor trabalhava permite interpretar a delação de Bauer como uma figuração da divisão intraclasses em Hollywood. Por meio das ações do contador em Force of Evil, Polonsky alerta os espectadores e, principalmente, seus companheiros na indústria cinematográfica, para o fato de que poderia haver entre eles casos de delatores nas audiências do HUAC. O desenrolar das investigações do comitê mostrou que o prognóstico de Polonsky estava correto.

Um dos casos mais famosos de "testemunha amigável” nas investigações do HUAC é o do diretor Elia Kazan, que deu dois depoimentos perante o comitê. No primeiro, em 14 de janeiro de 1952, Kazan admitiu ter feito parte do Partido Comunista Americano entre 1934 e 1936, período em que fez parte do Group Theatre de Nova Iorque, mas se recusou a nomear outros companheiros. Em 10 de abril de 1952, entretanto, o diretor solicitou ao comitê que retomasse seu depoimento. Nessa ocasião, Kazan entregou aos membros do HUAC uma extensa carta na qual detalha tanto suas atividades no período, quanto a participação de seus colegas em atividades do partido. Entre os nomeados nesse testemunho estão os atores J. Edward Bromberg, Phoebe Brand e Morris Carnovsky, além do dramaturgo

${ }^{201}$ Marx, K., Engels, F. Manifesto do Partido Comunista. São Paulo: Cortez, 1998, p. 12-13. 
Clifford Odets. Desses, somente o último não foi incluso na lista negra porque também colaborou com as investigações do $\mathrm{HUAC}^{202}$. Na introdução da sua carta, Kazan declara:

[E]rrei ao omitir esses nomes antes, porque o sigilo trabalha a favor dos Comunistas, e é exatamente o que eles querem. O povo Americano precisa dos fatos e todos os fatos sobre todos os aspectos do comunismo, a fim de lidar com ele de maneira sábia e efetiva. É minha obrigação como cidadão dizer tudo o que sei. $^{203}$

Tanto Bauer como Kazan têm em comum o fato de terem voluntariamente traído seus companheiros para salvar a própria pele; entretanto, enquanto o diretor tinha o objetivo de manter sua empregabilidade em Hollywood ao nomear comunistas ao HUAC ${ }^{204}$, as ações do contador de Force of Evil contêm um certo paradoxo, uma vez que o fechamento da banca de Leo determinava o desemprego de todos, incluindo o do próprio Bauer. Polonsky não aborda o assunto no filme, mas, no romance de Ira Wolfert, quando diz a Leo que quer sair, Bauer explica que "se eu não achar outra coisa, eu apelo para o seguro-desemprego. Eles estão dando seguros agora, não é como Hoover" ${ }^{205}$.

Contudo, como o desenrolar da narrativa nos mostra, o seguro-desemprego não seria o suficiente para garantir a tranquilidade de Bauer. Assim que faz a denúncia ao escritório de Hall e sai do apartamento, o contador é abordado, ainda na escada do prédio, por Wally; este oferece uma proposta de Bill Ficco, parceiro de Tucker na época da Lei Seca, que também pretende entrar no mercado de loterias ilegais em Nova Iorque como concorrente. Segundo Wally, Ficco precisa de uma lista de "bancas, banqueiros, cobradores e controladores de Tucker", e quer se encontrar com Leo para obter essas informações, tendo Bauer como mediador do encontro. O contador recusa a proposta, porque "não quer nada com gângsteres". "Como assim, gângsteres? São negócios.", responde Wally, enquanto Bauer retoma seu caminho.

${ }^{202}$ Cf. Odets, C. Communist Infiltration of the Hollywood Motion Picture Industry - Part 8. In: Hearings before the Committee on Un-American Activities House of Representatives. Washington: United States Government Printing Office, 1952, p. 3491-3511.

${ }^{203}$ Kazan, E. Communist Infiltration of the Hollywood Motion Picture Industry - Part 7. Ibidem, p. 2407.

${ }^{204}$ Ganhador de oito Oscars, entre eles o de melhor filme e melhor diretor, On the Waterfront (1954), dirigido por Kazan, é considerado pela crítica de esquerda uma defesa da figura do delator. O filme narra o conflito entre o ex-boxeador Terry Malloy (Marlon Brando) e seu chefe, o gângster Johnny Friendly (Lee J. Cobb), líder do sindicato dos estivadores de Nova Iorque. (Cf. On the Waterfront (1954) - IMDB. Disponível em http://www.imdb.com/title/tt0047296. Acessado em 01/12/2015).

${ }^{205}$ Wolfert, I. Tucker's People. Chicago: University of Illinois Press, 1943, p. 113. A comparação de Bauer faz referência às políticas do New Deal, pois o romance é ambientado em 1934, ano seguinte à primeira eleição de Franklin Delano Roosevelt à presidência. 
Nesse diálogo, Polonsky faz referência a mais um clichê do filme de gângster em Hollywood: uma vez envolvido com o crime organizado, não há retorno. Na década de 1930, tal clichê era utilizado pelos roteiristas como figuração das dívidas de honra dentro do crime organizado, que eram usadas pelos criminosos para manter a disciplina e estruturar as relações entre os membros da gangue. Em Force of Evil, a função do clichê permanece a mesma, mas seu uso é diverso. Segundo Polonsky, no raciocínio do contador,

\footnotetext{
"Eu só estou mantendo os livros contábeis em ordem! Estou fazendo algo perfeitamente adequado e aceitável. Não faço nada além de somar números. Do que sou culpado?". Ao mesmo tempo ele se sente terrível, porque ele sabe que está envolvido com a coisa toda.

Um homem que acha que está fazendo algo aceitável e que, de repente, é apanhado “de calças curtas" é o traidor perfeito. (...) É preciso ter comprometimento ao fazêlo. Bauer é assim. ${ }^{206}$
}

Dessa maneira, no julgamento do próprio Bauer, seu envolvimento com a gangue de Tucker se dá de forma periférica e involuntária. Ainda assim, logo depois de tentar se libertar desse vínculo por meio da delação ao procurador Hall, o contador é abordado por Wally, membro de outra gangue.

\section{O fechamento das possibilidades}

Essa sequência de movimentos da narrativa em torno de Bauer - que se inicia com a primeira batida policial encomendada por Joe na banca de Leo - configura um paulatino fechamento das possibilidades para o contador, que o filme demonstra formalmente por meio de closes em plongée no personagem. Tais enquadramentos constroem imageticamente a sensação de claustrofobia pela qual Bauer passa, pressionado simultaneamente pelo seu novo empregador (Tucker), pela concorrência (Ficco) e pela polícia.

\footnotetext{
206 Sherman, E, Rubin, M. Interview with Abraham Polonsky. In: Polonsky, A. Abraham Polonsky:
} interviews / edited by Andrew Dickos. Jackson: University of Mississippi Press, 2013, p. 61. 

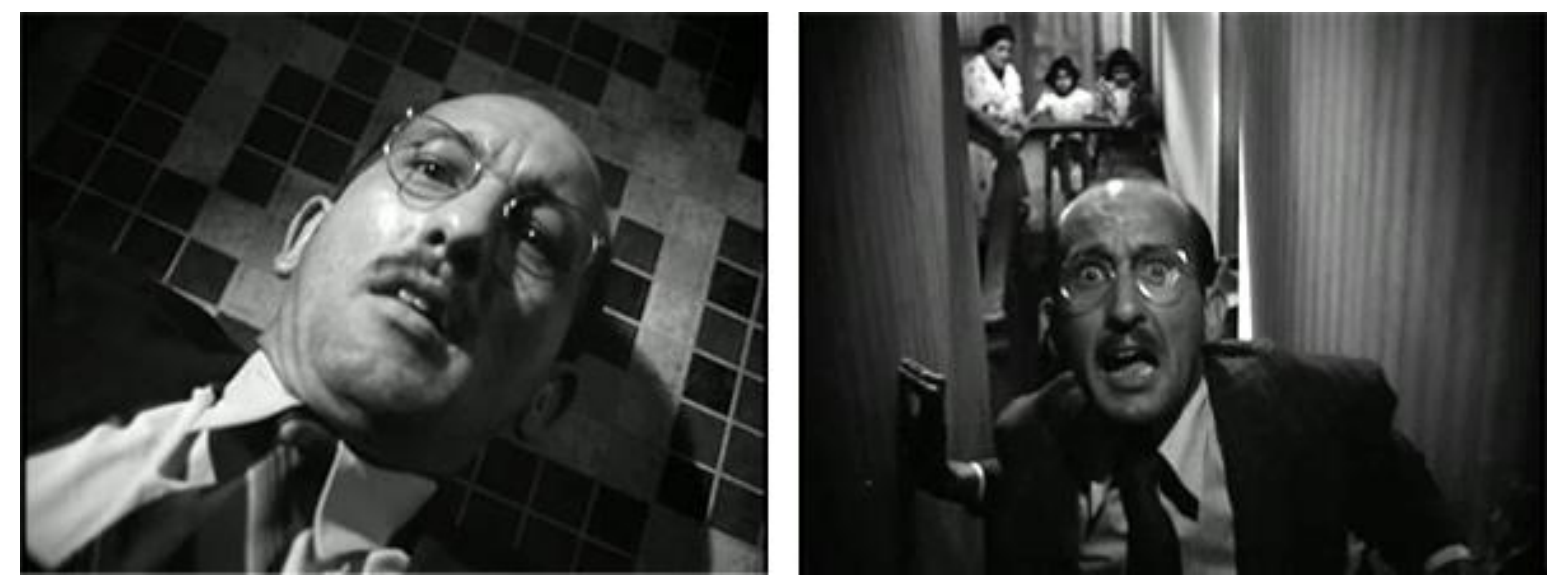

Figura 30 - Bauer enquadrado em plongée durante a primeira (esq.) e a segunda (dir.) batidas policiais na banca de Leo.

O encurralamento do personagem em Force of Evil também figura o "beco sem saída" em que os trabalhadores de Hollywood - e dos EUA de forma geral - se encontravam naquele momento histórico. Segundo o historiador Andrew E. Kersten, os movimentos trabalhistas atingiram seu ápice de desenvolvimento e de influência na política, na sociedade e na economia norte-americanas ao longo da década de 1940, colhendo os frutos plantados na década de 1930. Os sindicatos, segundo Kersten, eram "engrenagens importantes nos mecanismos do New Deal”, e alguns líderes sindicais acumularam certa relevância política nesse período. Entretanto, embora os trabalhadores tivessem conquistado algum progresso com programas como o Works Progress Administration (WPA) durante a Depressão, nada se compara ao que ocorreu com o início da Segunda Guerra Mundial, que criou condições para um desenvolvimento econômico sem precedentes em todos os setores industriais norteamericanos. Kersten cita, por exemplo, a indústria da construção civil, que registrava taxas de desemprego de $45 \%$ entre os trabalhadores do setor em 1935. Quatro anos depois, com o país em uma situação um pouco melhor, a cidade de Los Angeles conseguiu empréstimos de US\$ 33 milhões para reestabelecer o mercado de construção civil de todo o município. Um valor ainda maior foi cedido pelo governo Roosevelt para a construção, já na década de 1940, de uma única base da Marinha em San Diego, onde trabalhadores da AFL construíram uma estação de treinamento, um hospital, uma base aérea, e um depósito de armas. ${ }^{207}$ Tal revitalização da economia também trouxe consigo um aumento significativo no contingente de trabalhadores sindicalizados:

${ }^{207}$ Cf. Kersten, A. E. Dominance and Influence of Organized Labor: 1940s. In: Arnesen, R. Encyclopedia of U.S. Labor and Working-class History. Volume 1. London: Taylor \& Francis, 2007, p. 375. 
Em 1930, havia perto de 49 milhões de trabalhadores na força de trabalho. Somente 3.5 milhões, ou 7\% pertenciam a um sindicato. Em 1940, o proletariado norte-americano era composto por 53 milhões de trabalhadores, e 17\% era sindicalizado. O ápice dos números dos sindicatos veio durante a guerra, em 1945, quando havia quase 15 milhões de trabalhadores sindicalizados, o que correspondia de um quarto a um terço da força de trabalho. Em algumas áreas, como na indústria aérea, madeireira e naval, o percentual era muito maior. ${ }^{208}$

Dentro do esforço de guerra, o crescimento dos sindicatos e a aproximação com os líderes trabalhistas eram fundamentais para Roosevelt por dois motivos. Primeiro, porque quanto maior o número de trabalhadores sindicalizados, maior a força de trabalho direcionada para a indústria, o que aumentaria tanto a produção de guerra quanto a circulação de capital, ajudando o país a afastar o perigo de um retrocesso econômico e uma nova crise. Em segundo lugar, o aumento na relevância política dos líderes sindicais foi estimulado porque Roosevelt precisava da expertise desses sindicalistas para mobilizar, treinar e contar com a cooperação harmoniosa de trabalhadores. Os sindicatos eram, dessa maneira, "fundamentais em uma conversão tranquila para a produção de guerra" ${ }^{209}$. Na avaliação do historiador Howard Zinn, o advento da Segunda Guerra Mundial

\begin{abstract}
enfraqueceu a velha militância trabalhista da década de 1930 porque a economia da guerra criou milhões de novos empregos com salários altos. O New Deal teve sucesso somente na redução de 13 milhões para 9 milhões de desempregados. Foi a guerra que colocou todo mundo para trabalhar, e a guerra trouxe algo a mais: o patriotismo, que impulsionou a união de todas as classes contra os inimigos no exterior e tornou difícil mobilizar a ira contra as corporações. Durante a guerra, o CIO e a AFL se comprometeram em não convocar greves. ${ }^{210}$
\end{abstract}

Apesar da grande oferta de empregos no início da década de 1940, o grande temor da classe trabalhadora norte-americana era de que, depois da guerra, a Depressão voltasse alguns economistas da época previam índices de desemprego alarmantes para o período pósguerra, mais altos até do que os atingidos em meados da década de 1930. Com o intuito de evitar reações violentas, a AFL e a CIO implementaram um plano de metas para a luta política dos trabalhadores baseada em três ideais: empregos para todos, a implementação de

\footnotetext{
${ }^{208}$ Kersten, A. E. Dominance and Influence of Organized Labor: 1940s. In: Arnesen, R. Encyclopedia of U.S. Labor and Working-class History. Volume 1. London: Taylor \& Francis, 2007, p. 375. ${ }^{209}$ Idem.

${ }^{210}$ Zinn, H. A People's History of the United States: 1492 - Present. $3^{\text {rd }}$ ed. London: Routledge, 2015, p. 451-452.
} 
um sistema nacional de saúde, e a luta pelos direitos civis. ${ }^{211} \mathrm{O}$ primeiro era possível, de acordo com os liberais, "com planejamento adequado e uso efetivo dos vastos recursos do governo federal" em estradas, moradias e reformas urbanas. O segundo era uma demanda da classe trabalhadora desde as dificuldades vividas durante a Depressão, e ganhou força com o aumento significativo dos acidentes de trabalho nas fábricas durante a Segunda Guerra Mundial. Finalmente, os sindicatos usaram seu poder político para lutarem em prol da expansão dos direitos civis para os cidadãos americanos, especialmente os negros, uma vez que estes eram discriminados em até $90 \%$ dos empregos na indústria armamentista em todo o país. ${ }^{212}$

Ainda que a agenda proposta pela CIO e AFL fosse ambiciosa, havia um certo otimismo entre os líderes desses sindicatos porque ambos haviam se tornado forças significativas dentro da política norte-americana. Além de terem colaborado na reeleição de Roosevelt em 1944, tanto a CIO como a AFL tiveram participação nas decisões burocráticas tomadas pelo governo no período. Os sindicatos também contavam com o maior número de membros até então, e seus líderes imaginavam ter o apoio da opinião pública, pois contribuíram de forma significativa com o "arsenal da democracia" na vitória dos Aliados sobre o Fascismo. ${ }^{213}$ As negociações com o governo, entretanto, não evoluíam, o que levou à convocação de diversas greves:

Em 1943, o dobro de trabalhadores se envolveu com greves em comparação com o ano anterior. Houve perto de 3.800 greves em 1943 e quase 5.000 em 1944. Em 1945, houve 4.750 paralisações e, em 1946, 5.000 envolvendo 4.6 milhões de trabalhadores. No seu ápice, a greve de 1945-1946 foi maior do que as famosas greves de 1919. (...) O exemplo mais famoso foi a greve da United Automobile Workers (UAW) contra a General Motors. O presidente do Sindicato Walter Reuther não apenas exigia um aumento salarial e mais benefícios, como também solicitou à GM que "abrisse seus livros". Em outras palavras, a UAW queria participar da administração da corporação. Seguindo um padrão frequente nos anos de 1945 e 1946, o sindicato perdeu a greve, conseguindo ganhos ínfimos. Greves lideradas pela United Mine Workers e pela United Steelworkers tiveram resultados parecidos. As derrotas nas greves do período pós-guerra foram

${ }^{211}$ Cf. Kersten, A. E. Dominance and Influence of Organized Labor: 1940s. In: Arnesen, R. Encyclopedia of U.S. Labor and Working-class History. Volume 1. London: Taylor \& Francis, 2007, p. 376.

212 Ibidem, p. 376-377.

${ }^{213}$ Ibidem, p. 377. 
presságios de reveses maiores e mais devastadores para os trabalhadores organizados na década de 1940 e nas décadas seguintes. ${ }^{214}$

De acordo com Kersten, o enfraquecimento do movimento trabalhista no fim da década de 1940 teve diversas causas. A primeira delas foi início da Guerra Fria, que possibilitou à direita norte-americana rotular as demandas dos trabalhadores como reinvindicações de cunho comunista, e provocou uma forte oposição a todas as legislações referentes às metas propostas pela CIO e AFL. Em 1947, ano anterior ao lançamento de Force of Evil, o Congresso norte-americano - sob pressão dos empresários - aprovou o TaftHartley Act, uma série de medidas que restringiam o poder político e econômico dos sindicatos. A perseguição generalizada aos comunistas provocou desavenças internas nos sindicatos, o que culminou no rompimento das lideranças progressistas da CIO e da AFL, e no consequente arrefecimento das lutas trabalhistas. Tal situação tornou mais difícil o recrutamento de novos membros, e os sindicatos terminaram a década de 1940 muito mais fracos e vulneráveis do que no seu início. ${ }^{215}$

Segundo Polonsky, o período macarthista é continuação do processo descrito acima por Kersten e Zinn, e culmina na interrupção de diversos movimentos progressistas em todo o país. De acordo com o diretor de Force of Evil,

[é] preciso lembrar que a principal luta política que ocorreu no país - perto daquela época e até os últimos anos da guerra, e logo em seguida - foi a luta no movimento sindical, dentro do CIO, terminando na destruição da liderança de esquerda. Essa luta dentro dos sindicatos era enorme, e as consequências foram fatais, porque tornou possível a McCarthy operar contra as pessoas que perderam seus aliados. Porque os principais aliados desse movimento artístico e intelectual foram, obviamente, os sindicatos organizados, construídos durante a fundação do CIO, com todas as alianças em torno dela entre a burguesia, por assim dizer.

De fato, o triunfo do macarthismo foi a interrupção de um movimento social generalizado que havia começado antes da guerra, e havia se identificado com os objetivos da guerra. Quando a guerra acabou, a batalha se concentrou entre os dois ganhadores - os EUA versus URSS -, e aquele movimento social teve uma parada brusca, com as mudanças na política externa dos EUA e na vida interna do país. Dessa forma, a perseguição às pessoas de Hollywood na caça às bruxas era, de certa forma, uma consequência dessa derrota generalizada. Tal perseguição

\footnotetext{
${ }^{214}$ Kersten, A. E. Dominance and Influence of Organized Labor: 1940s. In: Arnesen, R. Encyclopedia of U.S. Labor and Working-class History. Volume 1. London: Taylor \& Francis, 2007, p. 378.

${ }^{215}$ Ibidem, p. 378-379.
} 
recebeu muita atenção porque todos sabiam quem eram essas estrelas. Mas ninguém sabia quem eram aqueles pequenos líderes de sindicatos, organizadores distritais, professores, e todos os anônimos que nunca chegam aos jornais, a não ser que sejam atropelados, assaltados ou mortos (...). Mas as pequenas vítimas de McCarthy nunca iam para os jornais, enquanto todo mundo de Hollywood era bem conhecido, ou poderia ser reconhecido facilmente pela simples menção dos seus nomes e os filmes onde trabalharam. ${ }^{216}$

As “pequenas vítimas” citadas por Polonsky são representadas em Force of Evil pelos funcionários de Leo, e a "derrota generalizada" da classe trabalhadora é enunciada por eles no reconhecimento da própria impotência perante o poder do monopólio de Tucker, conforme apontamos anteriormente. De modo geral, Force of Evil demonstra esse mal-estar da classe trabalhadora por meio de três registros característicos, de acordo com a crítica Christine Noll Brinckmann ${ }^{217}$ : em primeiro lugar, as cenas em espaços escuros e apertados, principalmente no caso do escritório de Leo, onde as janelas são fechadas por cortinas, inclusive durante o dia. Tais cenas concentram visualmente a ansiedade dos funcionários de Leo, ameaçados tanto pelo crime organizado como pela polícia. Não por acaso, um desses funcionários, Juice (Jack Overman) - nomeado somente no romance de Ira Wolfert -, tem problemas mentais e claustrofobia. O momento em que esse personagem é preso pela segunda vez e implora para que não seja levado no camburão, somado à resposta violenta dos policiais a esse pedido, representa o extremo dessa sensação de mal-estar. (Figura 31)

A reação de Juice na cena descrita acima também pode ser inclusa no segundo tipo de registro recorrente em Force of Evil: cenas de "intenso desconforto físico", como no atropelo sofrido por Bauer assim que a polícia invade a banca de apostas, ou na manifestação dos problemas cardíacos de Leo ao longo do filme (Figura 31), além da embriaguez de Joe dentro do bar, que o impede de se comunicar de maneira sensata com Doris.

\footnotetext{
${ }^{216}$ Polonsky, A. How the Blacklist Worked in Hollywood. In: Polonsky, A. Abraham Polonsky: interviews / edited by Andrew Dickos. Jackson: University of Mississippi Press, 2013, p. 60.

${ }^{217}$ Brinckmann, C. N. The Politics of Force of Evil: An Analysis of Abraham Polonsky's Preblacklist Film. In: Prospects. Vol. 6, October, 1981, p. 375-376.
} 

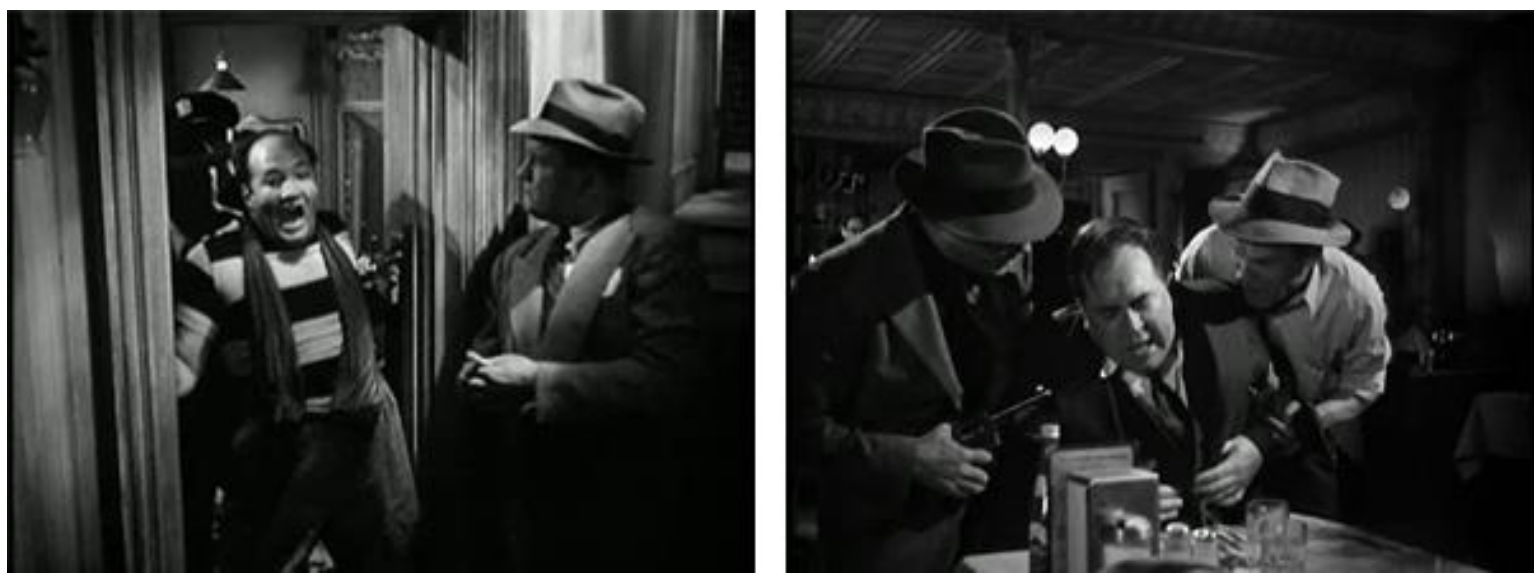

Figura 31 - Juice tenta impedir que seja levado para o camburão da polícia (esq.) e Leo sofre com problemas cardíacos no momento em que é sequestrado (dir.)

Em terceiro lugar, podemos apontar os registros dos personagens da classe trabalhadora passando por situações de frustração e impotência. Já apontamos anteriormente de que forma a ironia no discurso dos funcionários de Leo assinala esses sentimentos, e Brinckmann adiciona a essa equação o telefone, com

sua capacidade ameaçadora de controlar remotamente as pessoas e (...) [a] constante possibilidade de ser grampeado. É o protagonista que, na maior parte das vezes, vivencia - e transmite - essa ansiedade, pois sua impaciência e dinamismo fazem-no mais suscetível à frustração. Apesar de toda sua agitação e presença de espírito, Joe não é capaz de controlar o que está acontecendo. Suas ações são quase que inevitavelmente reações, e ele está sempre prestes a prevenir uma perda maior ou atrasado para impedir um desastre. Consequentemente, os espectadores sentem uma progressiva inquietação e uma urgência apreensiva, e somente no final é possível respirar livremente de novo. ${ }^{218}$

De fato, o telefone é uma presença constante ao longo de Force of Evil - Polonsky, inclusive, solicitou que um telefone de dimensões exageradas fosse construído especialmente para o filme, a fim de ressaltar sua presença no primeiro plano de alguns closes em Joe ${ }^{219}$-, e é interessante notar que, em todas as suas aparições, ele é usado como meio de comunicação com a lei e a ordem, figurados pela polícia (Joe e Bauer denunciam a

${ }^{218}$ Brinckmann, C. N. The Politics of Force of Evil: An Analysis of Abraham Polonsky's Preblacklist Film. In: Prospects. Vol. 6, October, 1981, p. 376.

${ }^{219}$ Cf. Sherman, E, Rubin, M. Interview with Abraham Polonsky. In: Polonsky, A. Abraham Polonsky: interviews / edited by Andrew Dickos. Jackson: University of Mississippi Press, 2013, p. 58. 
banca de Leo com um telefonema); pelo advogado para quem Leo liga no momento em que é preso pela primeira vez; e pelo Procurador Hall, que em momento algum aparece no filme, mas se faz presente por meio das notícias de jornal e do grampo telefônico que monitora os aparelhos de Joe e Tucker. ${ }^{220} \mathrm{O}$ telefone também protagoniza uma das sequências mais tensas da narrativa após o aviso de Edna Tucker a Joe de que Hall já havia grampeado os telefones:

Edna: Ben me disse que se escutar com cuidado e tentar algumas vezes pode pegálos no ato. Dá para ouvir um ‘clique'. Um pequeno ‘clique'. É o barulho de alguém tirando o telefone do gancho. O homem que escuta. Já usou seu telefone para falar coisas que ele não poderia ouvir?

Assim que Edna sai do escritório, Joe fecha a porta e o narrador diz, com uma música sombria ao fundo:

Joe [voz-over]: Eu esperava ter problemas com Hall. Estava prevenido, mas era um pouco assustador perceber que ele estava agindo tão rápido. Era algo preocupante. [há um corte e a câmera mostra em primeiro plano, à esquerda, a gaveta onde Joe esconde o telefone, e em segundo plano, à direita, Joe andando vagarosamente em direção à mesa] Era preciso tomar providências. Era algo para ser lembrado. [Joe coloca a mão no bolso do paletó e tira uma chave] Conversas telefônicas não são boas provas legais, mas elas dizem ao bom advogado onde procurar as evidências, o que elas poderiam ser. Era o primeiro passo para abrir um caso contra a organização. E a organização era Ben Tucker e eu. [Joe caminha até a gaveta e abre-a cuidadosamente] Quando você ganha a vida, você aceita os riscos. Mas eu assumi mais riscos por causa do Leo. Para lhe dar confiança. [Nesse momento, há um corte para um plano americano de Joe, sentado à mesa; ele pega o telefone da gaveta cuidadosamente e coloca-o sobre a mesa; a câmera mostra o telefone em primeiro plano e Joe em segundo; a iluminação da cena permite ver que o protagonista tem a tez molhada.] Eu havia mostrado meu rosto aos banqueiros naquela manhã. Fui duro com Bauer para facilitar para o Leo. Pessoas podem ser forçadas a falar. Será que o meu telefone também estava falando? [pequena pausa. Joe olha fixamente para o telefone] Um homem pode passar o resto da vida tentando lembrar o que não deveria ter dito. [Joe tira o telefone do gancho; a música de fundo cessa e o ruído da linha telefônica preenche a cena; há um corte para um plano de detalhe do fone próximo a orelha de Joe; subitamente,

${ }^{220} \mathrm{~A}$ única cena do filme em que o telefone aparece e é usado com outro fim é na tentativa de Doris ligar para sua mãe do tribunal, mas a ligação é interrompida por Joe, que abre a cabine telefônica para falar com a secretária. 
ouve-se um "clique"; corte para um outro plano de detalhe nos olhos de Joe, demonstrando surpresa; corte para o plano americano anterior; Joe disca um número e uma voz feminina responde].

Voz feminina: A hora é 7:23 e um quarto. [Joe desliga o telefone] (grifo nosso)
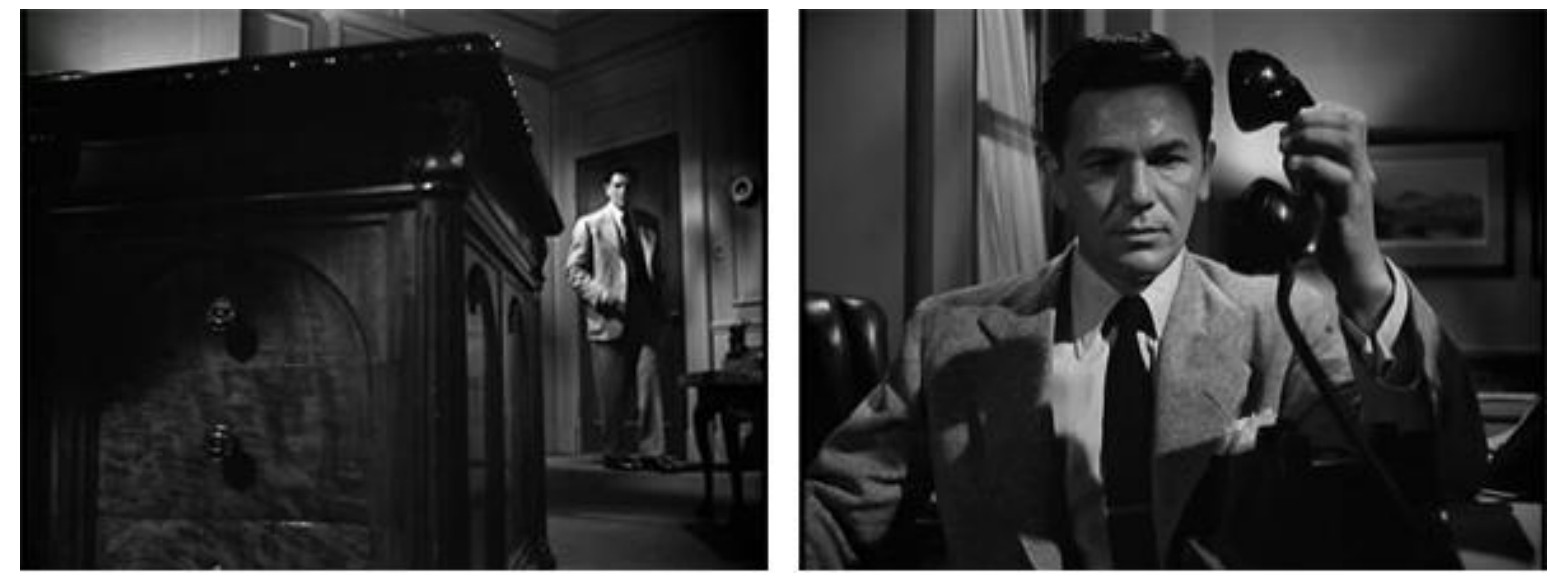

Figura 32 - Joe se aproxima da mesa de seu escritório (esq.) e tira o telefone do gancho (dir.)

Essa sequência registra a apreensão de Joe por meio de vários recursos. Primeiramente, na atuação de John Garfield, cujo semblante tenso e movimentação lenta e cuidadosa em cena denotam essa preocupação. Garfield sua frio e trata o telefone como alguém que se aproxima de uma bomba-relógio, prestes a explodir a qualquer instante com o menor passo em falso. Em segundo lugar, na narração, que acompanha as pausas de Joe em cena e enuncia a falta de controle de Joe sobre a situação ("Pessoas podem ser forçadas a falar. Será que o meu telefone também estava falando?’). Em terceiro lugar, no uso do som: a trilha sonora, nesse momento do filme, acompanha o aumento de tensão da cena até Joe retirar o fone do gancho; há também uma atenção especial para o ruído da linha telefônica e para o "clique" sutil, que confirma o grampo do telefone. Em quarto lugar, na montagem, ao mostrar planos de detalhe de fragmentos do personagem que realçam sua tensão.

Outro ponto que vale destacar nessa sequência se refere à linguagem utilizada pelo narrador. "When you make a living, you accept the risks" é o original do período grafado na passagem citada acima. Joe, por mais de uma vez ao longo do filme, usa essa frase para justificar suas ações, mas o contexto e a maneira como é utilizada nos chama a atenção. To make a living é uma expressão normalmente utilizada para descrever a profissão, ou o modo como alguém se sustenta e "ganha a vida". A expressão é sinônimo de "to make money", 
literalmente "fazer dinheiro", em português. A ausência proposital de um advérbio ou de uma locução adverbial na primeira oração (por exemplo, "When you make a living this way", "Quando você ganha a vida desse jeito") configura, na própria linguagem, a indistinção entre negócios legais e ilegais no filme, pois Joe não qualifica suas operações de um lado ou outro da lei. Em última análise, tal expressão também faz referência ao próprio trabalho dos artistas de esquerda de Hollywood que, naquele momento, já haviam presenciado a prisão dos Hollywood Ten e pressentiam o avanço das investigações do HUAC. O trabalho na indústria cinematográfica era, dessa maneira, arriscado, e Force of Evil sedimenta em sua forma esse senso de urgência:

\footnotetext{
O sucesso artístico de Polonsky, embora breve, foi possível graças a um amplo desenvolvimento em um setor crucial do cinema Americano. A qualidade superior dos filmes realizados por artistas sérios e politicamente engajados (nem todos, de maneira alguma, de esquerda) durante o período imediatamente anterior à lista negra é frequentemente atribuída à noção que os cineastas tinham de que o tempo estava acabando. (...) Mesmo antes que as intimações começassem a surgir em 1947, a engrenagem cinematográfica começou a escapar para a as mãos dos financiadores da Costa Leste, que cada vez mais ditavam os termos de sobrevivência dos estúdios. ${ }^{221}$
}

Além da apreensão de Joe, a composição de um dos planos dessa sequência também ressalta a impotência do personagem perante a situação. No momento em que Joe começa a se aproximar de sua mesa, Polonsky posiciona a câmera próxima ao chão, de modo a compor $3 / 4$ do plano com o móvel em primeiro plano à esquerda, e Joe, em segundo plano, à direita. (Figura 32) Ao compor o plano dessa maneira, o diretor "espreme" o protagonista na menor porção possível do enquadramento; ao fazê-lo, também exagera as proporções da mesa e, por consequência, do telefone dentro da gaveta. Tal composição incomum tem dois efeitos simultâneos: primeiro, registra formalmente o cerco que se fecha em torno de Joe nesse momento da narrativa; segundo, apequena o protagonista, cuja confiança no plano de enriquecer ilegalmente do dia para a noite - outrora tão grande - subitamente diminui diante da possibilidade de ter Hall em seu encalço mais cedo do que imaginava.

${ }^{221}$ Buhle, P., Wagner, D. A very dangerous citizen: Abraham Polonsky and the Hollywood Left. Berkeley and Los Angeles: University of California Press, 2001, p. 102. 


\section{A arquitetura de Nova Iorque e o "mundo real"}

O apequenamento de Joe ocorre outras duas vezes no filme: logo após descobrir que seu sócio, Wheelock, está ajudando Hall nas investigações, Joe pega uma arma em sua gaveta, enche os bolsos com o dinheiro que estava no cofre e sai do escritório. Um plano geral mostra o protagonista passando pelas duas pilastras de mármore que adornam a porta do escritório e caminhando lentamente em direção aos elevadores, enquanto o narrador diz:

Joe: [voz-over] Eu sabia que não voltaria mais para esse belo escritório. Eu podia ver as teias de aranha. E uma placa: Aluga-se escritório [Joe aperta o botão do elevador] para um advogado jovem e esperto, tentando se dar bem no mundo.

Há um corte e a câmera mostra Joe caminhando por uma Wall Street deserta em um plano geral bem amplo filmado a partir das escadarias do Federal Hall, com a estátua de George Washington à esquerda. A composição do plano deixa o protagonista diminuto na tela, principalmente se comparado com a estátua de Washington, a única figura humana da composição além de Joe. Uma música de tom grave e volume baixo acompanha a cena. $\mathrm{O}$ corte seguinte nos mostra um plano americano de Joe em contra-plongée, com a fachada imponente da Bolsa de Valores de Nova Iorque em segundo plano. Faltam ainda quase vinte minutos para o final do filme, mas o andar e o semblante do protagonista denotam sua completa derrota. Joe joga seu cigarro fora e, após um novo corte, vemos outro plano geral de Wall Street, dessa vez ao nível da rua, com Joe caminhando em direção à Trinity Church ao fundo, alternando passos rápidos e lentos, como se hesitasse sobre que rumo tomar.

A composição desse último plano enfatiza o apequenamento de Joe com dois recursos técnicos: primeiro, o plano geral amplo com a câmera fixa mostra o protagonista progressivamente menor à medida que se afasta da câmera; segundo, o uso de elementos da perspectiva - a linha do horizonte baixa ressalta a altura dos prédios que cercam Joe, e delineiam retas que levam ao ponto de fuga da imagem - nesse caso, a Trinity Church. A filmagem da igreja em contraluz realça a imponência de sua arquitetura, em oposição à figura diminuta de Joe no enquadramento. (Figura 33)

Vale notar que a sequência descrita acima estabelece uma rima visual com a abertura do filme, pois registra esse mesmo trecho de Wall Street, ainda que filmado sob outro ponto de vista - do alto de um dos prédios, no nível do topo da torre da igreja - e a câmera mostra 
em plongée as pessoas diminutas circulando pela rua. Ambas as cenas configuram visualmente a situação de Joe em momentos distintos da narrativa: se no início ele é um advogado bem-sucedido e está prestes a fazer o seu "primeiro milhão de dólares", depois de descobrir a traição de seu sócio, Joe sente o baque da derrota e torna-se mais um transeunte insignificante em Wall Street. Tais cenas também remetem ao tema recorrente em Force of Evil da contraposição entre o homem ambicioso e aquele sem grandes aspirações - é esse contraste, por exemplo, que define a relação entre os irmãos Morse: na primeira visita que faz ao escritório de Leo, Joe acusa o irmão de ser um "homem pequeno" porque este recusa a oportunidade que Joe lhe oferece de crescer e também ter um escritório "nas nuvens".
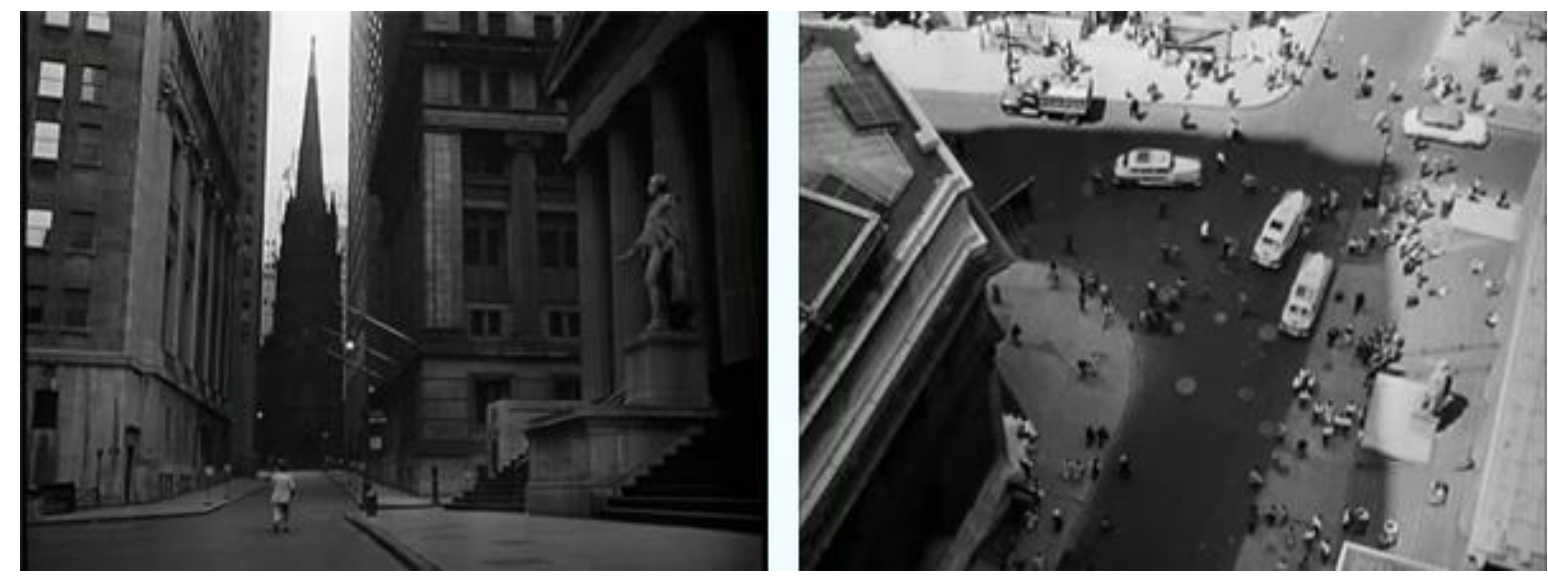

Figura 33 - Joe caminhando por Wall Street (esq.) e o plano geral em plongée que abre a narrativa (dir.)

O conflito entre os irmãos Morse e a ambição de Joe em Force of Evil nos remete ao tema do American Dream presente nas narrativas de gângster, uma vez que Joe - assim como Rico (Little Caesar) - também persegue os sonhos da "mobilidade social" e da "busca pela felicidade". Vale lembrar que o protagonista do filme de Polonsky tem o mesmo nome do parceiro de Rico, e a simbologia do average Joe e do "sonho do Zé Ninguém” também se aplica aqui: enquanto Joe Massara quer se inserir no mundo do espetáculo, Joe Morse quer ser o advogado milionário de Wall Street. Entretanto, uma das diferenças entre as narrativas da década de 1930 e Force of Evil é que Polonsky subverte a trajetória tradicional de "ascensão e queda" do protagonista e coloca Joe muito perto de conquistar seus objetivos dentro do crime organizado logo no início do filme. Dessa forma, enquanto Rico chega ao auge de sua escalada e cai abruptamente somente no fim de Little Caesar, Joe comemora o sucesso de seu plano logo aos trinta minutos de fita, o que deixa quase dois terços dela para 
que o diretor desenvolva a queda de seu protagonista. Tal organização da narrativa tem dois efeitos importantes em Force of Evil: em primeiro lugar, dá a Polonsky a oportunidade de desenvolver personagens secundários, como apontamos anteriormente no caso de Bauer; em segundo lugar, permite que o espectador tenha tempo hábil para refletir sobre as consequências do monopólio de Tucker no cotidiano de todos os personagens, e para perceber que "todas as situações e relações são permeadas pela mesmo conflito central: a questão de saber se é possível ou não ser financeiramente bem sucedido sem se corromper"222.

\section{A morte de Leo}

Depois de receber a notícia da morte de Bauer e do sequestro de Leo pela manchete do jornal, Joe vai até o escritório de Tucker a fim de descobrir o que estava acontecendo. Nesse momento, o advogado encontra Ficco e Tucker firmando um acordo. Ao perguntar sobre seu irmão, Joe fica sabendo por meio de Ficco que Leo está morto e seu corpo fora jogado no leito do rio Hudson. O advogado, então, discretamente tira o telefone grampeado de Tucker do gancho e faz a conversa ser ouvida pela polícia. Tucker percebe a traição e inicia-se um tiroteio, do qual somente Joe sobrevive. O PCA vetou boa parte da violência originalmente descrita por Polonsky no script de Force of Evil, que incluía cenas em que os gângsteres portavam escopetas de cano serrado, por exemplo. A solução do diretor foi substituir as armas grandes por outras mais simples, e filmar o tiroteio entre Ficco, Joe e Tucker praticamente na penumbra. O resultado do trabalho cumpre três objetivos simultaneamente: satisfaz as exigências da censura; mantém a harmonia visual do filme; e mostra Joe cumprindo sua vingança contra Ficco. Não há, contudo, qualquer sentimento de vitória, pois, embora saia vivo do conflito, Joe se sente derrotado por descobrir que seu irmão está morto.

O advogado resolve, então, procurar o corpo de Leo no rio antes de se entregar para a polícia. Nesse momento, o narrador diz:

\footnotetext{
${ }^{222}$ Brinckmann, C. N. The Politics of Force of Evil: An Analysis of Abraham Polonsky's Preblacklist Film. In:
} Prospects. Vol. 6, October, 1981, p. 368. 
Joe [voz-over]: Doris estava me esperando lá embaixo. Saímos antes da polícia chegar. Queria achar Leo, vê-lo uma vez mais. Estava amanhecendo, e naturalmente me sentia muito mal ali. Segui descendo... Mais e mais... Como se descesse ao fundo do poço... Para encontrar meu irmão.

A narração acompanha planos que mostram Joe descendo sozinho por escadarias e ladeiras, até as margens Rio Hudson, sob a ponte George Washington, ao norte da ilha de Manhattan. Como música extradiegética, temos o tema de Force of Evil, apresentado nos créditos do filme, mas com arranjos diferentes em cada momento da caminhada de Joe. No início, ela tem volume baixo, e um tom que evoca o suspense. Paulatinamente, no entanto, a melodia muda, aumenta de volume e torna-se grandiosa, porém suave e romântica no momento em que a tela é tomada por um plano geral da ponte sob a qual Joe corre em direção ao rio. (Figura 34)
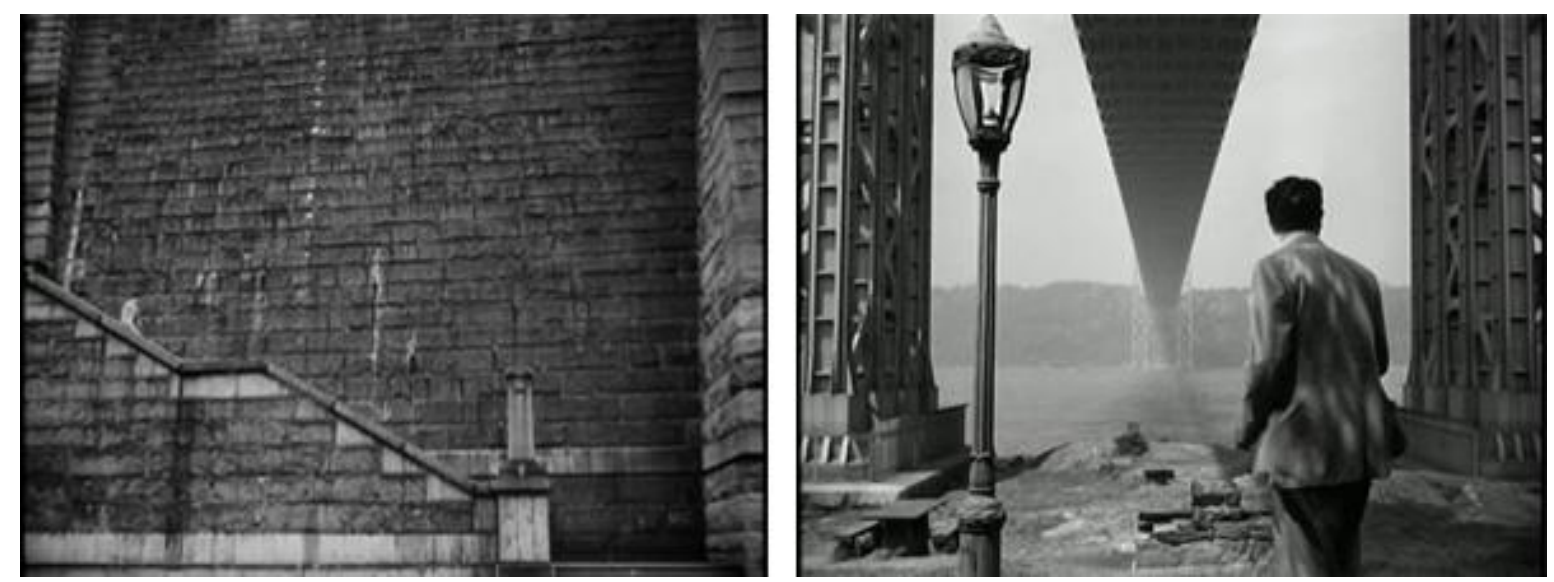

Figura 34 - Joe desce até a margem do rio Hudson.

Como elemento da composição do filme, a sequência descrita acima, dentro do modelo tradicional de roteiro cinematográfico, não contribui para o andamento da ação principal. Polonsky poderia ter resumido a movimentação de Joe rapidamente em dois ou três cortes, e gastado menos tempo de filme até que o protagonista encontrasse o corpo de Leo. Contudo, o diretor nos mostra, em quase dois minutos, dez planos longos em que Joe desce por escadas, ladeiras e muros até o leito do rio. Dessa maneira, a sequência dá destaque à materialização da queda do protagonista e reitera o contraponto entre forma e conteúdo utilizado outras vezes no filme: a fotografia elaborada dos planos e o ambiente criado pelo 
acompanhamento musical entram em conflito marcante com a narração pausada e melancólica, e com o conteúdo das cenas - que mostram Joe correndo até o corpo do irmão.

No instante em que Joe se aproxima de Leo, a melodia se transforma novamente, com tons agudos, intensos e trágicos. Quando Joe finalmente encontra o corpo de Leo, o narrador finaliza:

Joe [voz-over]: Encontrei o corpo de meu irmão lá no fundo. Eles o haviam jogado nas rochas, junto ao rio. Como um trapo velho e sujo que ninguém quer. Estava morto. E senti que eu o havia matado. Voltei para me entregar a Hall, porque se a vida de um homem pode ser vivida por tanto tempo e acabar assim, como lixo, então algo estava errado. E devia terminar, de um jeito ou de outro. Então decidi ajudar.

A regeneração de Joe ao final do filme faz parte das exigências do PCA, que não aprovaria roteiros em que o criminoso não fosse punido de alguma forma. Na sinopse de Force of Evil arquivada entre os documentos do PCA, o trecho que descreve o final do filme diz que Joe procura pelo corpo de seu irmão para vê-lo mais uma vez e "pedir perdão, bem como estabelecer o fato de que ele agora quer fazer tudo o que for possível para reparar os crimes cometidos"223. Sobre a interferência da censura em Force of Evil, Buhle e Wagner afirmam o seguinte:

O peso da narrativa do filme e as caracterizações são tão impactantes que a última concessão feita ao Breen Office tem pouca importância estética. Depois de uma sequência espetacular de dez cenas em que Joe desce do cenário urbano até as pedras debaixo da ponte para achar o corpo de Leo, com o tema "Regeneração", composto por David Raskin, crescendo ao fundo, tal concessão é quase um encolher de ombros. Mas o monopólio dos estúdios (naquele momento, um potencial monopólio de banqueiros sobre as tomadas de decisões em Hollywood) inegavelmente teve sua vingança contra um filme sobre o poder dos monopólios. A última fala do filme o assombraria como os depoimentos ao HUAC assombraram o período em que ele foi feito. Como Sklar aponta de maneira

${ }^{223}$ Carta de Stephen S. Jackson a David J. Hopkins. 5 de abril de 1948. In: Force of Evil files. Production Code Administration Archive, Margaret Herrick Library, Academy of Motion Picture Arts and Sciences. Los Angeles, California, p. 21. 
alarmante: "Em 1948, nem Garfield nem Polonsky haviam enfrentado a decisão que o Joe Morse da ficção, encurralado pelo Breen Office, foi forçado a tomar". ${ }^{224}$

Como pudemos observar, a matéria histórica sobre a qual Polonsky trabalhava durante a produção de Force of Evil era uma sequência de desventuras e oportunidades perdidas para os movimentos trabalhistas. Se as "derrotas nas greves do período pós-guerra foram presságios de reveses maiores e mais devastadores para os trabalhadores organizados na década de 1940", pode-se dizer que o diagnóstico feito por Polonsky para a classe trabalhadora em Force of Evil também não era nada animador, uma vez que o filme registra uma sequência de traições de classe entre os personagens, a começar o de Joe em relação a seu irmão. De acordo com Buhle e Wagner,

\begin{abstract}
todas as linhas do enredo levam à mesma conclusão: a culpa de Joe sobre sua traição e como ela começa a ditar todas as suas ações. Nós sabemos que em algum ponto ele deve se reconciliar com Leo, não somente como um homem de negócios corrupto que quer dividir seu lucro, mas em um sentido mais amplo. O filme não dá indícios de como essa reconciliação poderia acontecer, e em um mundo tão corrupto tal ato pode nem ser possível. ${ }^{225}$
\end{abstract}

Por mais que o final reestabeleça a ordem por meio do arrependimento e da punição de Joe, tal reconciliação não ocorre, pois o filme nos mostra que o resultado da aliança de classes é a ruína: ao trabalhar em prol do monopólio de Tucker e, simultaneamente, tentar proteger Leo, Joe destruiu ambos. Dessa maneira, assim como em Little Caesar, também é possível aplicar o conceito de ironia trágica ao percurso de Joe, uma vez que o protagonista de Force of Evil naufraga "no caminho que tomou justamente para escapar ao naufrágio",226. As ações de Joe também entram no conceito de "tragédia moderna", sobre o qual o crítico cultural Raymond Williams afirma:

\begin{abstract}
$\mathrm{Na}$ tragédia antiga, como Hegel a vê, as personagens claramente representam os fins éticos substanciais; ao passo que na tragédia moderna os fins parecem inteiramente pessoais, e o nosso interesse é direcionado não para a "afirmação e necessidade éticas", mas antes para o "indivíduo isolado e suas condições”. (...) O conflito no interior do herói trágico tende a substituir o conflito encarnado em
\end{abstract}

\footnotetext{
${ }^{224}$ Buhle, P., Wagner, D. A very dangerous citizen: Abraham Polonsky and the Hollywood Left. Berkeley and Los Angeles: University of California Press, 2001, p. 121-122.

${ }^{225}$ Ibidem, p. 121.

${ }^{226}$ Pessoa, P. A ironia trágica de Machado de Assis. In: Viso - Cadernos de estética aplicada. Rio de Janeiro, Vol. I, n 1 , jan-abr/2007, p. 3-4.
} 
homens particulares; e o isolamento do herói trágico, que Hegel apontara como uma característica da tragédia moderna, se generaliza com o pressuposto espiritual decisivo. $^{227}$

O isolamento de Joe em Force of Evil se dá por meio de suas ações "com fins inteiramente pessoais", calcadas na ideologia do American Dream. É o "personagem em si, e desse modo, o destino individual, que são enfatizados"228 acima da coletividade que o protagonista - e outros personagens, como Bauer e Doris - representam. Tal qual Rico em Little Caesar, Joe está mais próximo da individualidade burguesa do que da luta coletiva ao lado de seus irmãos de classe.

Force of Evil também delineia o estabelecimento de monopólios dentro do contexto mais amplo no capitalismo por meio de figurações dos processos no âmbito do crime organizado sem recorrer aos clichês hollywoodianos, ou seja, os personagens não são romantizados ou heroicizados, e o crime, como é o caso dos jogos ilegais, não é apresentado dentro da sociedade como exceção, mas como regra cotidiana e amplamente aceita. Dessa maneira, o que Force of Evil nos mostra é que a corrupção é resultado da "força maligna" e irracional do capitalismo, e o filme culpa o sistema econômico, e não uma deficiência moral inata do ser humano, pelas formas de sociabilidade corrompidas. Em última análise, Force of Evil questiona o próprio conceito de corrupção e seu pressuposto de que algo era bom e se deteriorou. Desde seu surgimento, o capitalismo sobrevive e se alimenta da desigualdade social; da concentração dos meios de produção nas mãos dos capitalistas; e da exploração dos produtores, que nada possuem além de sua força de trabalho - não há, portanto, bondade alguma na raiz do sistema.

Por meio do comportamento de Joe em relação a seus antigos irmãos de classe e sua traição a Leo, Polonsky nos mostra que, enquanto não houver uma mudança radical na política e na economia, as divisões intraclasse continuarão a existir e o poder destrutivo do capitalismo perdurará. Assim, qualquer tipo de reconciliação mais ampla continuará cada vez mais longe no horizonte.

Entretanto, mais do que "pouca importância estética", a concessão às demandas da censura na sequência final tem pouca relevância política perto do que Polonsky e sua equipe conseguiram ao levar adiante um projeto como Force of Evil em pleno macarthismo. Em

\footnotetext{
${ }^{227}$ Williams, R. Tragédia Moderna. São Paulo: Cosac Naify, 2002, p. 56-57.
}

228 Ibidem, p. 56. 
outras palavras, se cada corte feito pela censura representa uma derrota, nosso trabalho procurou mapear as vitórias configuradas no filme.

Ao refuncionalizar a narrativa do gângster, por exemplo, Polonsky obteve dois efeitos complementares: em primeiro lugar, tornou o filme mais didático ao explicitar homologias estruturais entre o crime organizado e o mundo dos negócios, e ao incluir a figura do narrador, que explica ao espectador o funcionamento da loteria e das bancas de apostas, ao mesmo tempo em que reforça a ironia e o sarcasmo que marcam o tom do filme como um todo; e, em segundo lugar, ao escolher John Garfield para o protagonista da narrativa e concentrar boa parte do filme nas consequências do monopólio de Tucker no cotidiano dos funcionários de Leo, Polonsky consegue estabelecer uma relação com o espectador da classe trabalhadora, que pode ver de maneira crítica tanto a ação monopolista do capital, como as alianças e traições de classe.

A grande vitória de Polonsky, no entanto, está no fato de que Force of Evil apresenta, por meio de contraposições entre forma e conteúdo, a contradição entre a ruína da matéria histórica e suas possibilidades criativas imanentes; entre o descontrole do sistema capitalista e o controle sobre a estética do filme. Ainda que sem a total posse dos meios de produção, mas sob condições de trabalho propícias e cercado de outros artistas engajados, Polonsky fez de seu filme um ato político, capaz de apresentar ao espectador a materialização de uma vitória simbólica sobre os limites do cinema dramático através do exercício da imaginação livre e de aproximações com a forma do teatro épico. 


\section{Considerações finais}

(...) os vultosos custos dos filmes comerciais, que inevitavelmente submetem sua produção ao controle das corporações multinacionais, tornam improvável a presença de qualquer conteúdo político genuíno, a o mesmo tempo que asseguram a vocação dos filmes comerciais para veículos de manipulação ideológica. Não há dúvidas de que é isso o que ocorre, se nos ativermos apenas à intenção do cineasta, que tem que se limitar, consciente ou inconscientemente, às circunstâncias objetivas. Mas esse argumento nega a identificação do filme com o conteúdo político da vida cotidiana, com a lógica política que já é inerente à matéria-prima com que o cineasta precisa trabalhar: uma lógica política como essa não irá, portanto, manifestar-se como uma mensagem política explícita, tampouco transformará o filme em uma declaração política livre de ambiguidades. Irá, contudo, contribuir para o surgimento de profundas contradições formais, às quais o público não pode deixar de notar, tenha ou não os instrumentos conceituais para compreender o que tais contradições significam.

Fredric Jameson 229

Mais do que a figura do gângster e do crime organizado, vimos ao longo desse trabalho que tanto Little Caesar como Force of Evil têm em comum outro elemento importante para nossa análise: o embate entre a censura em Hollywood e a representação de questões ligadas diretamente aos problemas da classe trabalhadora - seja na Depressão norte-americana na década de 1930, seja durante o macarthismo na década de 1940. Através da análise das cenas, aliada ao estudo do contexto histórico, do material teórico e da fortuna crítica sobre os filmes de gângster, pudemos estabelecer as diferentes estratégias adotadas no registro desse embate.

No primeiro capítulo, a análise das cenas de Little Caesar nos permitiu compreender diversas características do filme de gângster, como o estabelecimento do "sistema de convenções de representação" nas produções do gênero - que resultou nas fórmulas

229 Jameson, F. Classe e alegoria na cultura de massa contemporânea. In: As marcas do visível. Rio de Janeiro: Graal, 1995, p. 39. 
narrativas de "ascensão e queda" do protagonista, e na presença da figura do delator, por exemplo - e o processo de criminalização da classe trabalhadora imigrante no cinema, por meio do estabelecimento do "mito da Máfia" no cinema falado. Pudemos entender, também, como a indústria cinematográfica, após a ameaça das ações antitruste do Estado norteamericano, procurou se reestruturar internamente através da criação da Motion Picture Producers and Distributors of America (MPPDA) e da autocensura, na figura do Production Code, cuja função, mais do que eliminar temas "moralmente questionáveis" dos filmes, era acalmar os ânimos de Wall Street e salvar Hollywood de uma crise financeira.

Finalmente, vimos no primeiro capítulo de que maneira os problemas enfrentados pelos trabalhadores durante a Depressão - como a luta pelo espaço no mercado de trabalho; a desilusão com o American Dream; e a administração do tempo - surgem de maneira latente em Little Caesar por força da matéria histórica envolvida nas condições de produção, independente das intenções dos produtores e a despeito dos esforços da censura, na forma de homologias estruturais entre o enredo do filme e o funcionamento do capitalismo em momentos de crise; entre o crime organizado e os negócios.

Tais homologias são elevadas a outro patamar em Force of Evil. No segundo capítulo, vimos como Polonsky e sua equipe refuncionalizaram os elementos da narrativa de gângster em Hollywood (como a ascensão e queda do criminoso, o American Dream, a figura do delator) e do próprio cinema noir surgido na década de 1940 (o narrador-protagonista, a "atmosfera" sombria e o tipo de iluminação utilizada nas cenas) a fim de que a matéria histórica viesse à tona. Tal qual Little Caesar, Force of Evil também registra o crime organizado como regra, e não como exceção dentro do capitalismo; contudo, as homologias estruturais entre os negócios legais e ilegais são expostas de maneira muito mais direta e carregadas de ironia e sarcasmo nos diálogos e narrações escritos por Polonsky do que naqueles que se vê no filme de Mervyn LeRoy.

Por meio do estudo dos personagens de Force of Evil, pudemos notar que Polonsky avança em questões como a representação da classe trabalhadora no filme gângster ao figurar tanto a divisão intraclasses através da delação de Bauer, como a aliança de classes na relação entre Joe e Tucker. Por sua vez, a descrição e análise dos recursos técnicos utilizados no filme - como o uso da narração, da iluminação, do som, da montagem e da composição das cenas - nos revela experimentações executadas ao longo da narrativa por Polonsky e sua equipe com o objetivo de gerar uma tensão proposital entre a forma do filme e seu conteúdo, mesmo sob as exigências do mercado cinematográfico, a vigília da censura, e a constante 
ameaça de perseguição política. A recorrência dessas experimentações nos levou à conclusão de que o princípio organizador do filme é a contraposição entre o controle estético e o descontrole do sistema. $\mathrm{O}$ desequilíbrio entre a sofisticação formal e a barbárie social no conteúdo do filme configura a busca dos realizadores de Force of Evil por um modelo de cinema contra-hegemônico.

As estratégias adotadas nos dois filmes não foram as únicas tentativas de registrar as contradições da vida social no cinema. É possível dizer, contudo, que Force of Evil e Little Caesar foram obras bem-sucedidas nesse sentido simplesmente por terem chegado às salas de exibição. No caso específico de Polonsky, sua experiência nos mostra a importância de ser um estrategista dentro da indústria cultural, uma vez que tentativas mais radicais, quando não foram devidamente conduzidas por táticas semelhantes, resultaram em problemas como o que o diretor Herbert Biberman e sua equipe enfrentaram com o filme Salt of the Earth (1954), considerado um marco no cinema de esquerda norte-americano. O filme narra a greve ocorrida em 1951 dos trabalhadores da Empire Zinc Company, no Novo México. De acordo com o crítico M. Keith Booker,

\footnotetext{
Salt of the Earth é incrivelmente lúcido ao delinear a luta trabalhista central dentro de um contexto mais amplo do sistema capitalista. Também é altamente eficaz na figuração do papel exercido pelo gênero e pela etnicidade dentro desse sistema. Evita clichês, apresentando os mineradores e suas famílias como seres humanos realistas que não são nem romantizados, nem heroicizados. Esse realismo também é auxiliado pelo filme se basear em fatos, sendo a luta dos mineradores mexicanoamericanos no sudeste um dos mais importantes conflitos trabalhistas da década de $1950 .{ }^{230}$
}

Todavia, Salt of the Earth sofreu as consequências de seu radicalismo: durante as filmagens, seus produtores sofreram pressões do HUAC, do FBI e da CIA. Depois de finalizado, os proprietários de salas de cinema, cedendo às pressões governamentais e corporativas, boicotaram o filme, que, dessa maneira, teve alcance limitado. ${ }^{231}$

Outra experiência semelhante à de Biberman foi enfrentada pelo dramaturgo alemão Bertolt Brecht na produção de Kuhle Wampe (1932), o qual, segundo o próprio artista,

\footnotetext{
${ }^{230}$ Booker, M. K. From box office to ballot box: the American political film. Westport: Prager Publishers, 2008 , p. 74.

${ }^{231}$ Ibidem, p. 72-73.
} 
"retrata as terríveis condições dos desempregados em Berlim"232. Brecht já havia sofrido percalços com a indústria cinematográfica alemã na adaptação de sua Ópera dos três vinténs para o cinema em 1931 - na ocasião, a Nero-Film Company, que havia adquirido os direitos de adaptação da obra, ignorou as alterações no texto feitas pelo dramaturgo na sua própria obra e seguiu adiante com a produção do filme sem a participação de Brecht; esse,

por sua vez, sabendo o que fizera no teatro, mas sem conhecer o terreno onde estava pisando, acreditou no que diziam as cláusulas relativas a seu direito de adaptação do texto porque achou que a empresa estivesse interessada em fazer do filme um experimento equivalente ao realizado no palco. Ele confessa abertamente essa ingenuidade, que demorou um pouco para compreender. ${ }^{233}$

De acordo com Iná Camargo Costa, o objetivo de Brecht era desenvolver "os materiais que na peça ficaram apenas pressupostos em função das limitações do palco" a fim de que o resultado final não ficasse aquém do seu potencial e configurasse, dessa forma, "um retrocesso artístico". Com a atitude da empresa, o dramaturgo alemão abriu um processo contra a Nero-Film Company exigindo seus direitos e descobriu que, aos olhos da justiça, ele estava errado, pois havia dificultado o andamento do trabalho ao atrasar a entrega da sinopse no prazo acordado, por exemplo, o que dava à Nero-Film o direito de repassar a elaboração do roteiro a outros escritores. Brecht recorreu da primeira sentença judicial, que havia sido desfavorável a ele, e entrou em acordo com a empresa, sendo indenizado por perdas e danos. $^{234}$

Após a experiência da adaptação da Ópera dos três vinténs, Brecht e a equipe de produção de Kuhle Wampe decidiram trabalhar de forma independente e tomaram as precauções legais para assegurar os direitos autorais da obra. Segundo o próprio Brecht,

\footnotetext{
isso nos custou o direito à remuneração habitual, mas ganhamos uma liberdade sobre o nosso trabalho impossível de se obter de outra maneira. (...) Quando estávamos completando nosso trabalho, que a todo momento enfrentava a possibilidade de interrupção, depois de noventa e cinco por cento do filme rodado e grandes somas de dinheiro gastas, bem como empréstimos feitos, um de nossos credores, que tinha o monopólio dos aparatos que precisávamos, nos disse que a
}

\footnotetext{
${ }^{232}$ Brecht, B. The Kuhle Wampe Film. In: Silberman, M. (org.) Brecht on Film and Radio. London: Methuen Publishing Limited, 2000, p. 207.

${ }^{233}$ Costa, I. C. Brecht no cativeiro das forças produtivas. In: Nem uma lágrima: teatro épico em perspectiva dialética. São Paulo: Expressão Popular, 2012, p. 141.

${ }^{234}$ Idem.
} 
companhia havia perdido o interesse no lançamento do filme e preferia amortizar as dívidas a permitir que continuássemos trabalhando. Ela [a companhia] acreditava que filmes de melhor qualidade aumentavam as expectativas da imprensa, o que não necessariamente coincidiria com aquelas dos espectadores, e que o filme não seria interessante comercialmente porque o Comunismo já não representava uma ameaça na Alemanha. Por outro lado, outras companhias não nos dariam crédito porque temiam que o filme fosse censurado, menos pelo Estado do que pelos proprietários de cinema em si. O primeiro é, de fato, somente expressão do último, uma vez que o Estado, em qualquer caso, não é um terceiro distante da luta, mas sim um executor de grandes negócios e, como tal, uma das partes. $^{235}$

De fato, a previsão das companhias que recusaram o financiamento de Kuhle Wampe se concretizou, e o filme, logo depois de ser finalizado, foi imediatamente proibido pela censura. Uma das objeções feitas ao filme foi em relação à maneira como foi executada a cena que mostra o suicídio de um jovem desempregado. Os argumentos do censor surpreenderam o próprio Brecht:

Sim, vocês ficarão surpresos que eu censuro sua representação por não ser suficientemente humana. Vocês não registraram uma pessoa, mas, sim, vamos admitir, um tipo. Seu trabalhador desempregado não é um indivíduo real, não uma pessoa de carne e osso, distinta de outras pessoas, com preocupações, alegrias e destino particulares. Ele é esboçado de maneira superficial. Como artistas vocês devem me desculpar pela expressão, nós aprendemos muito pouco sobre ele, mas as consequências são de natureza política e me forçam a desaprovar o lançamento do filme. Seu filme propõe que o suicídio é típico, que não é simplesmente o ato desse ou daquele (patologicamente inclinado) indivíduo, mas o destino de uma classe social inteira! Seu ponto de vista é de que a sociedade induz os jovens ao suicídio por negar a eles a possibilidade de trabalhar. E vocês sequer evitaram indicar aos desempregados o que fazer a fim de mudar a situação. Não, senhores, vocês não se comportaram como artistas, não aqui. Vocês não estavam interessados em mostrar o destino impressionante de um indivíduo, o que ninguém os impediria de fazê-lo. ${ }^{236}$

Após o parecer negativo do censor alemão - cujos argumentos são bem mais perspicazes do que aqueles encontrados nos relatórios do PCA aos quais tivemos acesso -,

\footnotetext{
${ }^{235}$ Brecht, B. The Kuhle Wampe Film. In: Silberman, M. (org.) Brecht on Film and Radio. London: Methuen Publishing Limited, 2000, p. 205.

${ }^{236}$ Ibidem, p. 208.
} 
diversos cortes foram realizados até que Kuhle Wampe fosse lançado em 1932. Sua exibição, contudo, foi limitada em Berlim, Paris e Moscou, e a ascensão de Hitler ao poder em 1933 tirou o filme de circulação. ${ }^{237}$

Os exemplos de Salt of the Earth e Kuhle Wampe nos mostram que as estratégias adotadas por Polonsky e sua equipe eram questão de sobrevivência dentro da indústria cinematográfica. Em um período histórico marcado pela censura e pela constante ameaça de perseguição política, adaptar e, no limite, criar rupturas na forma da narrativa hollywoodiana em nome de um conteúdo progressista era o desafio que se colocava diante dos produtores de Force of Evil. Ao superar esses obstáculos e conseguir o selo de aprovação do PCA, o filme conquistou a chancela necessária para que pudesse ser distribuído no mercado interno - dentro do oligopólio estabelecido pelas grandes corporações em Hollywood, a distribuição era um problema muito maior para os estúdios independentes do que a produção do filme em si. "Meios de produção, no caso do cinema, desde os anos 1920 significam também meios de distribuição e exibição, como demonstram os seguidos desastres da produção independente" 238

Os objetos analisados nesse trabalho registram, portanto, formas distintas de se lidar com a matéria histórica em filmes de gângster. Little Caesar representa um marco nos filmes do gênero por seu pioneirismo dentro do cinema falado, e tem o mérito de abordar temas com enorme potencial crítico. Contudo, como observamos no primeiro capítulo, tal potencial, em diversos momentos, resulta menos das intenções dos realizadores do que um efeito do inconsciente político da obra. No caso de Force of Evil, por sua vez, a contraposição entre forma e conteúdo configura uma estratégia deliberada de representação da matéria histórica com objetivos políticos. Dessa maneira, a realização de Force of Evil em si é uma intervenção dentro do aparato produtivo. Sob um contexto de muitas restrições, caracterizado principalmente pela censura, presente em Hollywood desde a década de 1930, e pela perseguição política no fim da década de 1940, coube à equipe de produção do filme uma determinada sagacidade e, sobretudo, um esforço coletivo para produzir uma obra de interesse político. Nossa leitura de Force of Evil é pautada, portanto, pela estratégia no uso das fórmulas industriais para provocar seu deslocamento a fim de que o filme fosse capaz de introduzir teoremas de alguma ousadia e relevância social.

${ }^{237}$ Cf. Brecht, B. The Kuhle Wampe Film. In: Silberman, M. (org.) Brecht on Film and Radio. London: Methuen Publishing Limited, 2000, p. 203.

${ }^{238}$ Costa, I. C. Brecht no cativeiro das forças produtivas. In: Nem uma lágrima: teatro épico em perspectiva dialética. São Paulo: Expressão Popular, 2012, p. 144. 


\section{Referências bibliográficas}

ADORNO, T. A indústria cultural - o Iluminismo como mistificação das massas. In: Indústria cultural e sociedade. São Paulo: Paz e Terra, 2002.

ANDERSEN, T. Red Hollywood. In: Ferguson, S., Groseclose, B. Literature and the Visual Arts in Contemporary Society. Columbus: Ohio State University Press, 1985.

BALIO, T. Grand Design: Hollywood as a modern business enterprise, vol. 5, 19301939. New York: Simon \& Schuster Macmillian, 1993.

BENJAMIN, W. A obra de arte na era da reprodutibilidade técnica. In: Obras escolhidas, Magia e técnica, arte e política, v. I trad. S.P. Rouanet. São Paulo: Brasiliense, 1985.

Jogo e Prostituição. In: Charles Baudelaire: um lírico no auge do capitalismo. $1^{\text {a }}$. ed. São Paulo: Brasiliense, 1989.

BERGMAN, A. We're in the Money: Depression America and its films. Chicago: Ivan R. Dee, 1992.

BERNSTEIN, M. Controlling Hollywood: Censorship and Regulation in the Studio Era. London: A\&C Black, 2000.

BOOKER, M. K. From box office to ballot box: the American political film. Westport: Prager Publishers, 2008.

BRAVERMAN, H. Labor and monopoly capital: the degradation of work in the twentieth century. New York: Monthly Review Press, 1998.

BRECHT, B. On Film Music. In: Silberman, M. (org.) Brecht on Film \& Radio. London, Methuen, 2000.

. The Kuhle Wampe Film. In: Silberman, M. (org.) Brecht on Film and Radio. London: Methuen Publishing Limited, 2000.

BRINCKMANN, C. N. The Politics of Force of Evil: An Analysis of Abraham Polonsky's Preblacklist Film. In: Prospects. Vol. 6, October, 1981.

BROE, D. Film Noir, American Workers, and Postwar Hollywood. Gainesville: University Press of Florida, 2009. (Kindle Edition)

BUHLE, P., WAGNER, D. A very dangerous citizen: Abraham Polonsky and the Hollywood Left. Berkeley and Los Angeles: University of California Press, 2001.

BUHLE, P.; WAGNER, D. Radical Hollywood. New York: The New Press, 2002. 
BURNETT, W. R. Little Caesar. New York: The Dial Press, 1958.

CARR, V. S. Dos Passos: a life. Evanston: Northwestern University Press, 2004.

CEPLAIR, L., ENGLUND, S. The Inquisition in Hollywood: Politics in the Film Community, 1930-1960. Oakland: University of California Press, 1983.

CLEMENT, P. F.; REINIER, J. S. (ed.). Boyhood in America: An Encyclopedia, Volume 1. Santa Barbara: ABC-Clio, 2011.

COSTA, I. C. Palestra sobre o ensaio O Autor como Produtor. In: Soares, M., Cevasco, M. E. (ed.) Crítica cultural materialista. São Paulo: Humanitas, 2008.

. Tragédia no século XX. In: WILLIAMS, R. Tragédia moderna. São

Paulo: Cosac Naify, 2011.

Brecht no cativeiro das forças produtivas. In: Nem uma lágrima: teatro épico em perspectiva dialética. São Paulo: Expressão Popular, 2012.

CULLEN, J. The American Dream: A short history of an idea that shaped a nation. New York: Oxford University Press, 2003.

DEBORD, G. A sociedade do espetáculo. Rio de Janeiro: Contraponto, 1997.

DENNING, M. The Cultural Front: The Laboring of American Culture in the American Century. New York: Verso, 1996.

DICK, B. Radical Innocence: A Critical Study of the Hollywood Ten. Lexington: University Press of Kentucky, 2009.

DOHERTY, T. P. Pre-code Hollywood: sex, immorality, and insurrection in American cinema, 1930-1934. New York: Columbia University Press, 1999.

EISENSTEIN, S. Declaração sobre o futuro do cinema sonoro. In: A forma do filme. Rio de Janeiro: Jorge Zahar Ed., 2002.

FABIAN, A. Card sharps and bucket shops: gambling in nineteenth-century America. New York: Routledge, 1999.

FORÇA do Mal. Direção: Abraham Polonsky. Fortaleza: Classic Line, 2007. 1 DVD (78 min), NTSC, P\&B. Título original: Force of Evil.

FORCE OF EVIL files. Production Code Administration Archive, Margaret Herrick Library, Academy of Motion Picture Arts and Sciences. Los Angeles, California.

FRIEDMAN, A. Writing for Visual Media. Burlington: Focal Press, 2010. 
GANSBERG, A. L. Little Caesar: A Biography of Edward G. Robinson. Maryland: Scarecrow Press, 2004.

GARDAPHE, F. L. Mafia stories and the American gangster. In: Nickerson, Catherine R. The Cambridge Companion to American Crime Fiction. Cambridge: Cambridge Univeristy Press, 2010.

GEADA, E. Os mundos do cinema. Lisboa: Editorial Notícias, 1998.

HAUG, W. F. Crítica da Estética da Mercadoria. São Paulo: Editora UNESP, 1996.

HOBSBAWM, E. Rebeldes Primitivos - Estudos sobre formas arcaicas de movimentos sociais nos séculos XIX e XX. Rio de Janeiro: Zahar Editores, 1978.

JAMESON, F. Marcas do Visível. Rio de Janeiro: Graal, 1995.

On Interpretation. In: The Political Unconscious: Narrative as a social symbolic act. London and New York: Routledge, 1981

KAMINSKY, S. M. Little Caesar and its Role in the Gangster Film Genre. In: Philadelphia: Journal of Popular Film, Vol. 1, Iss. 3, 1972.

KAZAN, E. Communist Infiltration of the Hollywood Motion Picture Industry - Part 7. In: Hearings before the Committee on Un-American Activities House of Representatives. Washington: United States Government Printing Office, 1952.

KERSTEN, A. E. Dominance and Influence of Organized Labor: 1940s. In: Arnesen, R. Encyclopedia of U.S. Labor and Working-class History. Volume 1. London: Taylor \& Francis, 2007.

KUHN, A., WESTWELL, G. A Dictionary of Film Studies. Oxford: Oxford University Press, 2012.

KYVIG, D. E., JEFFERS, H. F. Repealing National Prohibition. Kent: Kent State University Press, 2000.

LEWIS, J. Hollywood v. Hardcore: how the struggle over censorship saved the modern film industry. New York: New York University Press, 2000.

LIDDICK, D. The Mob's Daily Number: Organized Crime and the Numbers Gambling Industry. Lanham: University Press of America, 1999.

LIMA, L. L. O. Aparência e Essência: da Alienação ao Fetiche. In: Itinerarius Reflectionis. Vol II, no 5, jul-dez 2008.

LITTLE Caesar. Direção: Mervyn LeRoy. Burbank: Warner Home Video, 2005. 1 DVD (78 min), NTSC, P\&B. 
LÖWY, M. Walter Benjamin: aviso de incêndio - uma leitura das teses "Sobre o conceito de história”. São Paulo: Boitempo Editorial, 2007.

LUKÁCS, G. Introdução aos escritos estéticos de Marx e Engels. In: MARX, K., ENGELS, F. Cultura, arte e literatura: textos escolhidos/Karl Marx e Friedrich Engels. São Paulo: Expressão Popular, 2010.

MALAND, C. Film Gris: Crime, Critique, and Cold War Culture in 1951. In: Film Criticism, vol. 26, no. 3, 2002.

MALTBY, R. Censorship and Self-Regulation. In: Nowell-Smith, G. (ed.). The Oxford History of World Cinema. New York: Oxford University Press, 1996. More Sinned Against than Sinning: The Fabrications of "Pre-Code Cinema”. In: Senses of Cinema, Issue 29. Melbourne: RMIT University, 2003. Disponível em http://sensesofcinema.com/2003/feature-articles/pre_code_cinema/. Acessado em 09/01/2015.

MANDEL, E. Delightful Murder - A social history of the crime story. Minneapolis: Univeristy of Minnesota Press, 1984.

MARTIN, C. J. Dance Marathons: Performing American Culture of the 1920s and 1930s. Jackson: Univ. Press of Mississippi, 1994.

MARX, K. O capital: Crítica da economia política, Livro I: O processo de produção do capital. São Paulo: Boitempo Editorial, 2013.

MARX, K., ENGELS, F. Manifesto do Partido Comunista. São Paulo: Cortez, 1998.

MASON, F. American Gangster Cinema - from Little Caesar to Pulp Fiction. New York: Palgrave Macmillian, 2002.

MCGILLIGAN, P.; MATE, K. "W. R. Burnett: The Outsider”. In: Backstory: interviews with screenwriters of Hollywood's golden age. Berkeley and Los Angeles: University of California Press, 1986.

MESSADIÉ, G. A crise do mito americano - Réquiem para o super-homem. São Paulo: Ática, 1989.

MUNBY, J. Public Enemies, Public Heroes - Screening the Gangster from Little Caesar to Touch of Evil. Chicago: The University of Chicago Press, 1999.

ODETS, C. Communist Infiltration of the Hollywood Motion Picture Industry - Part 8. In: Hearings before the Committee on Un-American Activities House of Representatives. Washington: United States Government Printing Office, 1952. 
PANDEY, A. Academic Dictionary of Film, Television and Theatre. Delhi: Isha Books, 2005.

PELLS, R. H. Radical Visions and American dreams: culture and social thought in the Depression years. New York: Harper\&Row, 1973.

PESSOA, P. A ironia trágica de Machado de Assis. In: Viso - Cadernos de estética aplicada. Rio de Janeiro, Vol. I, n ${ }^{\circ} 1$, jan-abr/2007.

PINTO, G. A. A organização do trabalho no século 20: taylorismo, fordismo, toyotismo. São Paulo: Expressão Popular, 2010.

POLONSKY, A. Abraham Polonsky: interviews / edited by Andrew Dickos. Jackson: University of Mississippi Press, 2013.

REIS, C. Discurso ideológico do neo-realismo português. Coimbra: Almedina, 1983.

RICE, R. The Business of Crime. London: Victor Gollancz LTD, 1956.

ROSS, S. J. Hollywood Left and Right: How Movie Stars Shaped American Politics. New York: Oxford University Press, 2011.

RUTH, D. E. Inventing the public enemy: the gangster in American culture, 19141934. Chicago: The University of Chicago Press, 1996.

SCHRADER, P. Notes on Film Noir. In: Silver, A., Ursini, J. (ed.) Film Noir Reader. Pompton Plains: Limelight Editions, 1996.

SCHULTHEISS, J., SCHAUBERT, M. Force of Evil: The Critical Edition, by Abraham Polonsky. Northridge: The Center for Telecommunication Studies California State University, 1996.

SHADOIAN, J. Dreams and Dead Ends: The american gangster film. New York: Oxford University Press, 2003.

SHAKESPEARE, W. Julio César - tradução de Carlos Lacerda. Rio de Janeiro: Record, 1963.

SKLAR, R. Movie-Made America: A Cultural History of American Movies. New York: Random House, 1975.

SLOCUM, D. J. (ed.) Violence and American Cinema. New York: Routledge, 2001.

STADLER, J., MCWILlIAM, K., Screen Media: Analysing Film and Television. Crows Nest: Allen \& Unwin, 2009.

SZONDI, P. Teoria do Drama Moderno (1880-1950). São Paulo: Cosac Naify, 2001. 
WARSHOW, R. "The gangster as a tragic hero". In: SILVER, A., Ursini, J. Gangster Film Reader. Pompton Plains: Limelight Editions, 2007.

WILliAMS, R. Tragédia Moderna. São Paulo: Cosac Naify, 2002.

WOLFERT, I. Tucker's People. Chicago: University of Illinois Press, 1943.

WOODIWISS, M. Organized Crime and American Power. Toronto: University of Toronto Press, 2001.

ZINN, H. A People's History of the United States. New York: HarperCollins Publishers, 2005 .

Outras fontes de referência

Hollywood, Moral Censorship, and the Motion Picture Production Code, 1927-1968. Disponível em http://gdc.gale.com/archivesunbound/hollywood-moral-censorship-and-themotion-picture-production-code-1927-

1968/?searched=production+code\&advsearch=exactphrase\&highlight=ajaxSearch_highlig ht+ajaxSearch_highlight1. Acessado em 11/01/2015.

History of Cinema, Series 1, Hollywood and Production Code Administration. Herrick Library. Archives Unbound. Disponível em

http://proxy.library.upenn.edu:3437/gdsc/i.do?\&id=GALE\%7CSC5106190494\&v=2.1\&u= upenn_main\&it=r\&p=GDSC\&sw=w\&viewtype=fullcitation. Acessado em 11/01/2015.

Louis XVI, king of France and Navarre (1754-1793), wearing his grand royal costume in 1779 - Antoine-François Callet - Google Cultural Institute. Disponível em: https://www.google.com/culturalinstitute/asset-viewer/louis-xvi-king-of-france-andnavarre-1754-1793-wearing-his-grand-royal-costume-in-1779/9gFrdyY6xDaHgw?hl=en.

Acessado em 17/06/2014.

Mervyn LeRoy - IMDB. Disponível em http://www.imdb.com/name/nm0503777/ Acessado em 10/01/2014.

On the Waterfront (1954) - IMDB. Disponível em http://www.imdb.com/title/tt0047296 Acessado em 01/12/2015

Ronald Reagan Testimony:

http://www.cla.calpoly.edu/cla/legacies/rsimon/rsimonsite/Hum410/ReaganHUAC.htm Acessado em 04/01/2014. 